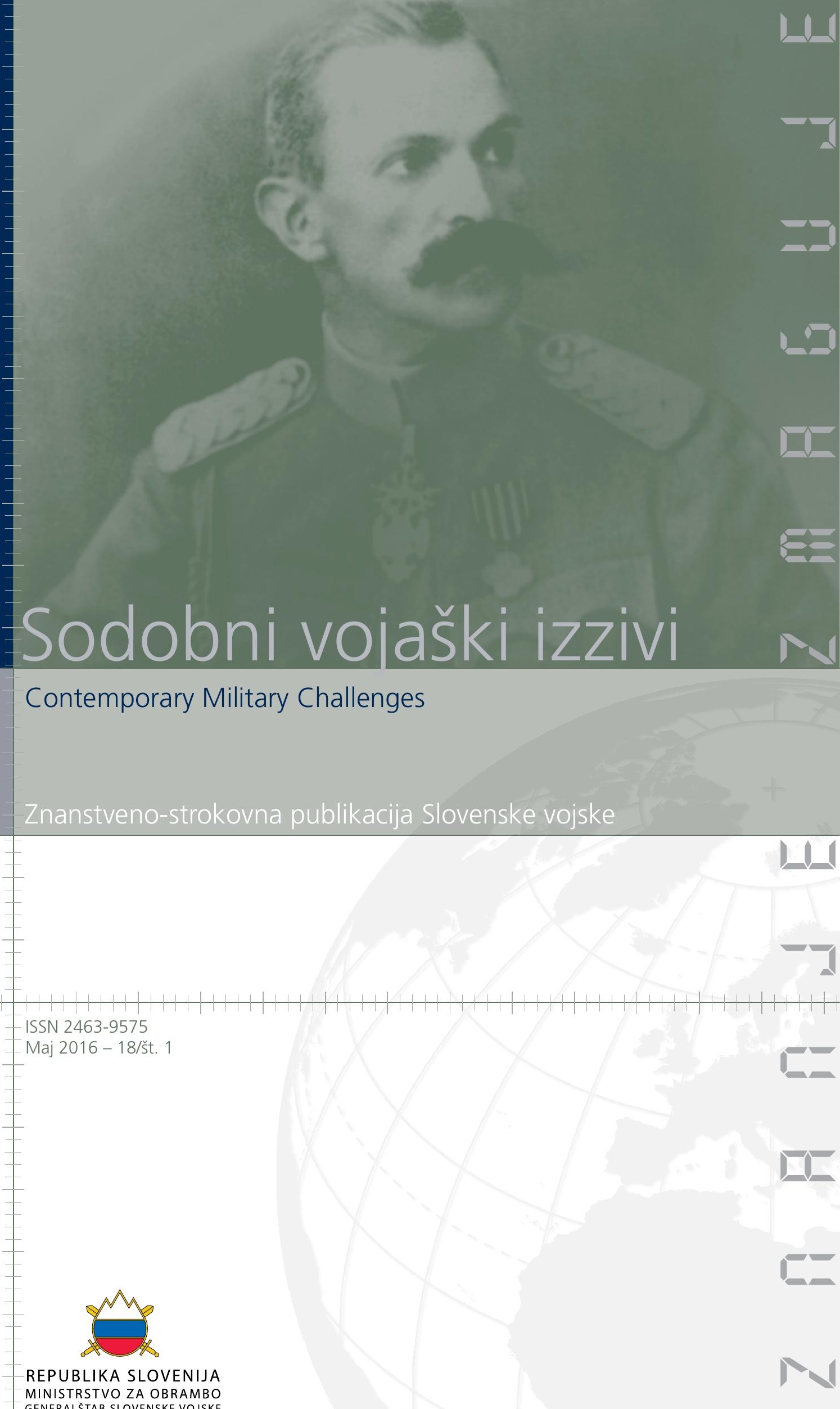



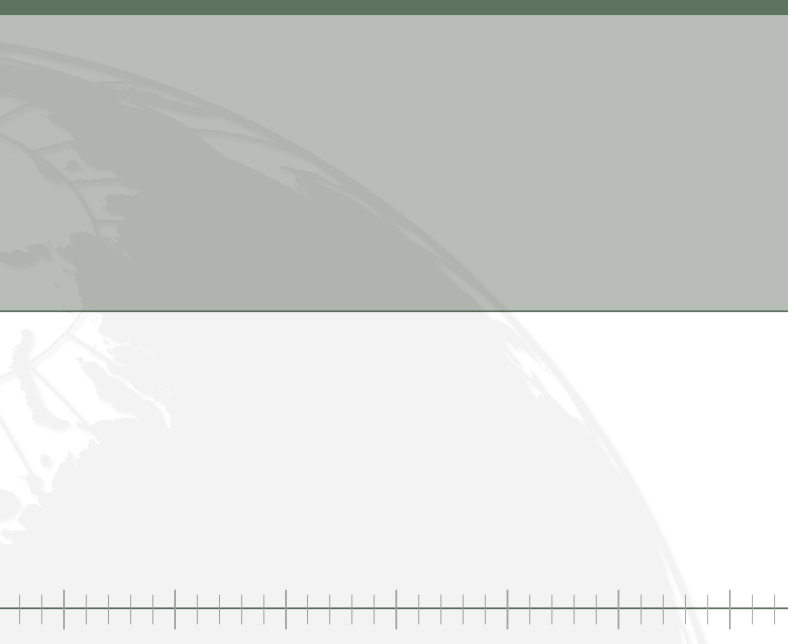


\section{Sodobni vojaški izzivi}

Contemporary Military Challenges

Znanstveno-strokovna publikacija Slovenske vojske

ISSN 2463-9575

UDK 355.5(479.4)(055)

Maj 2016 - 18/št. 1

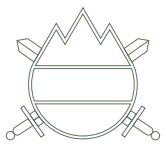




\section{Izdajatelj \\ Publisher}

Glavni urednik

Executive Editor

Odgovorni urednik Managing Editor

Uredniški odbor Editorial Board

Sekretar

Secretary

Uredniški svet

Editorial Council

Prevajanje

Translation

Lektoriranje

Proofreading

Oblikovanje

Design \& Graphic

Tisk

Print

ISSN

Naklada

Edition

Revija je dostopna

na spletni strani

Publication web page

E-naslov urednice Managing Editor

e-mail address
Generalštab Slovenske vojske

General Staff of the Slovenian Armed Forces

generalmajor Alan Geder (OF-7)

dr. Liliana Brožič

višja vojaška uslužbenka XIII. razreda dr. Valerija Bernik (OF-4)

višji vojaški uslužbenec XIV. razreda dr. Denis Caleta (OF-5)

polkovnik dr. Tomaž Kladnik (OF-5)

dr. Igor Kotnik

polkovnik dr. Vojko Obrulj (OF-5)

dr. Maja Garb

višja praporščakinja Nataša Cankar (OR-9)

dr. Andrej Anžič, Evropska pravna fakulteta, Nova Gorica

dr. Gorazd Bajc, Narodna in študijska knjižnica, Trst

dr. Anton Bebler, Fakulteta za družbene vede, Ljubljana

dr. Damir Črnčec, Fakulteta za državne in evropske študije, Brdo

dr. Bastian Giegerich, International Institute for Strategic Studies, London

dr. Olivera Injac, Univerzitet Donja Gorica, Podgorica

dr. Sergei Konoplyev, Harward University, Cambridge

generalmajor v pokoju Ladislav Lipič (OF-7, ret.)

dr. Thomas Mockaitis, DePaul University, Chicago

dr. Klaus Olshausen (OF-8, ret.), Clausewitz-Gesellschaft e.V., Hamburg

generalpodpolkovnik dr. Iztok Podbregar (OF-8), Fakulteta za organizacijske vede, Kranj

dr. Tibor Szvircsev Tresh, Militärakademie an der ETH, Zürich

dr. Thomas Young, Center for Civil-Military Relations, Monterey

Ana Hazler, Nela Vujačić

Iris Žnidarič

Služba za strateško komuniciranje

Skupina Opus Design

Prima Print d.o.o.

2232-2825 (tiskana različica/print version)

2463-9575 (spletna različica/ on line version)

300 izvodov/copies

http://www.slovenskavojska.si/publikacije/ sodobni-vojaski-izzivi/

http://www.slovenskavojska.si/en/publications/contemporary-military-challenges/

liliana.brozic@mors.si

Prispevki, objavljeni v Sodobnih vojaških izzivih, niso uradno stališče

Slovenske vojske niti organov, iz katerih so avtorji prispevkov.

Publikacija je uvrščena v bibliografsko zbirko podatkov COBISS.SI

in PAIS International.

Articles, published in the Contemporary Military Challenges do not reflect the official viewpoint of the Slovenian Armed Forces nor the bodies in which the authors of articles are employed.

The publication is indexed in bibliography databases COBISS.SI

and PAIS International. 


\section{OBOROŽENE SILE DANES}

»Nikogar ne morem ničesar naučiti.

Lahko jih samo vzpodbudim k razmišljanju. "

Sokrat

\section{ARMED FORCES TODAY}

»I cannot teach anybody anything.

I can only make them think.«

Socrates 



\section{VSEBINA}

CONTENTS

7

Liliana Brožič

UVODNIK

OBOROŽENE SILE DANES

11

Liliana Brožič

EDITORIAL

ARMED FORCES TODAY

\section{5}

Pavel Vuk

TEORETIČNI VIDIKI ODNOSA MED STRATEGIJO IN OBRAMBNIM PLANIRANJEM NA VARNOSTNO-OBRAMBNEM IN VOJAŠKEM PODROČJU

THEORETICAL ASPECTS OF THE RELATION BETWEEN THE STRATEGY AND DEFENCE PLANNING IN SECURITY, DEFENCE AND MILTTARY FIELDS

\section{7}

Mehmedin Tahirović

RAZVOJ OBRAMBNEGA SISTEMA ČRNE GORE

DEVELOPMENT OF THE DEFENCE SYSTEM OF MONTENEGRO

\section{1}

Gregor Zupan

GOSTUJOČI OBRAMBNI ATAŠEJI: PREDNOSTI IN POMANJKLIVOSTI ROVING DEFENCE ATTACHÉS: ADVANTAGES AND DISADVANTAGES

73

Vinko Vegič

POJAV IN KONCEPTUALIZACIJA HIBRIDNEGA VOJSKOVANJA

EMERGENCE AND CONCEPTUALISATION OF HYBRID WARFARE 
93

Viktor Potočnik

KONCEPT EŠALONIRANJA OGNJEV IN SISTEMI OGNJENE PODPORE $\checkmark$ SLOVENSKI VOJSKI

ECHELONMENT OF FIRES AND INDIRECT FIRE SYSTEMS IN THE SLOVENIAN ARMED FORCES

\section{1}

Maja Garb

RAZVOJ POJMA IN KONCEPTA CIVILNO-VOJAŠKEGA SODELOVANJA IN USKLAJEVANJA $\vee$ MIROVNIH OPERACIJAH DEVELOPMENT OF THE TERM AND THE CONCEPT OF CIVIL-MILITARY COOPERATION AND CO-ORDINATION IN PEACE OPERATIONS

\section{9}

Andreas Hauptmann Kaiser

GORSKE ENOTE NEMŠKIH OBOROŽENIH SIL

THE GERMAN ARMED FORCES MOUNTAIN TROOPS

\section{1}

SLIKOVNO GRADIVO

PHOTOS

\section{5}

AVTORJI

AUTHORS

\section{1}

NAVODILA AVTORJEM ZA OBLIKOVANJE PRISPEVKOV

\section{7}

INSTRUCTIONS FOR THE AUTHORS OF PAPERS 


\section{UVODNIK}

\section{OBOROŽENE SILE DANES}

Leto 2016 je za Republiko Slovenijo zelo pomembno. Spominjamo se namreč, kako smo se državljanke in državljani pred 25 leti odločili za samostojno in demokratično pot, za pot pomembnih odločitev in sprememb. Veliko se je zgodilo od takrat. Nabrali smo si veliko izkušenj, več znamo in vemo. Ob pomembnih obletnicah navadno namenjamo veliko pozornosti mejnikom, ki so prehojeno pot zaznamovali. Pri obletnicah in zgodovinskem spominu pa nas navdušuje tudi, da iz njih lahko črpamo zamisli za prihodnost.

V uredniškem odboru Sodobnih vojaških izzivov smo si za letos postavili cilj, da z zadnjo številko letnika, ki bo imela naslov Republika Slovenija - prvih samostojnih petindvajset let $v$ mednarodnem varnostnem okolju in bo izšla decembra, počastimo petindvajset let samostojne Slovenije. Za to številko si želimo prispevke, ki kažejo na poznavanje slovenske zgodovine in izkušenj na področju varnosti, obrambe in vojaštva, a so obogateni s poudarkom na aktualnih vsebinah in predlogih za njeno prihodnost znotraj mednarodnega varnostnega okolja.

Tretja številka, ki bo izšla oktobra, bo imela naslov Mednarodna varnostna skupnost na razpotju. Pričakujemo prispevke o novostih, ki jih prinašata vrh Nata v Varšavi in nova evropska obrambna strategija, o različnih aktualnih varnostnih tveganjih, predvsem pa mogočih odzivih nanje. Pri odzivih na varnostna tveganja je ključna preventiva, kot so predvidevanja, načrtovanje, oblikovanje in usklajevanje strategij ter na koncu njihovo kakovostno uresničevanje.

Druga številka v osemnajstem letu izhajanja bo naslovljena Ženske, mir in varnost ob 15. obletnici Resolucije VS OZN 1325. V preteklosti sta v Sloveniji že izšla dva zbornika na temo žensk v oboroženih silah. Prvega je izdalo Ministrstvo za obrambo leta 1995, drugi pa je nastal leta 2002 v sodelovanju ministrstva s Fakulteto za družbene vede. To pa bo prva številka Sodobnih vojaških izzivov, ki bo namenjena tej temi. 
Prva številka letošnjega letnika ima naslov Oborožene sile danes.

Z izbranimi naslovi in temami se bomo tako leta 2016 posvetili preteklosti, sedanjosti in prihodnosti ter ženskam, miru in varnosti.

Prvi prispevek številke o oboroženih silah danes ima naslov Teoretični vidiki odnosa med strategijo in obrambnim planiranjem na varnostno-obrambnem in vojaškem področju. Pavel Vuk pravi, da »/.../ naložba države v razvijanje strateške misli ter planskega znanja in veščin ne bi smela biti predmet kalkulacije vloženih sredstev, ampak predmet dolgoročne investicije v razvijanje miselnih procesov, zamisli o prihodnjih vojaških ciljih, konceptih bojevanja in prihodnjih opcijah oboroženih sil,« in meni, da strategijo ter obrambno planiranje upravičeno uvrščamo med najpomembnejše in hkrati tudi najzahtevnejše aktivnosti vsake države.

Mehmedin Tahirović in Olivera Injac predstavljata Razvoj obrambnega sistema Črne gore. Kot pravita, ima vsaka država pri iskanju najboljšega modela za zaščito svoje varnosti tudi svoje strateške razloge in posebnosti, ter nadaljujeta, da so pri vključevanju $\mathrm{v}$ evroatlantske integracije reforme in graditev vseh elementov nacionalne varnosti Črne gore, še zlasti pa obrambnega sistema, veliko cenejši, raven njihove učinkovitosti pa je veliko višja.

Gostujoči obrambni atašeji: prednosti in pomanjkljivosti je naslov članka, v katerem nas Gregor Zupan seznanja z načini delovanja obrambnih atašejev, ki se zaradi zmanjševanja finančnih sredstev in vpliva sodobnih tehnologij v zadnjih letih pojavljajo predvsem kot rezidenčni ali gostujoči obrambni atašeji. V članku avtor razmišlja, kakšne so prednosti in slabosti enih in drugih, še posebno v funkciji razvoja diplomatske karierne poti.

Vinko Vegič piše o Pojavu in konceptualizaciji hibridnega vojskovanja. Izpostavlja vprašanja opredeljevanja koncepta hibridnega vojskovanja na splošno ter na primeru Ukrajine in tako imenovane Islamske države, pri čemer opredeli njegove temeljne značilnosti. V nadaljevanju razpravlja o možnostih in vprašanjih zoperstavljanja hibridnemu vojskovanju ter ugotavlja, da je tudi v Sloveniji nujen razmislek o tem, kaj nova strateška realnost, ki se trenutno kaže s pojavom hibridnega vojskovanja na vzhodnem in južnem obrobju Nata (Ukrajina, Sirija in Irak), prinaša v našo varnostno stvarnost.

Koncept ě̌aloniranja ognjev in sistemi ognjene podpore v Slovenski vojski je naslov teme, ki se ji je posvetil Viktor Potočnik. Kot pravi, je namen članka preprost: oblikovati pogled SV na vlogo in nalogo sistemov, ki zagotavljajo posredne ognje za ognjeno podporo na taktični ravni od ravni voda do brigade. V članku je to naredil z razlago koncepta ešaloniranja ognjev in njegovega pomena za uspeh ognja in manevra na bojišču. Ali mu je to uspelo oziroma kako, si lahko preberete v nadaljevanju. 
Na civilno-vojaško sodelovanje na splošno, še posebno pa v Natu in Evropski uniji, ter na posebnosti takega sodelovanja med oboroženimi silami in humanitarnimi organizacijami se je osredotočila Maja Garb v članku Razvoj pojma in koncepta civilno-vojaškega sodelovanja in usklajevanja v mirovnih operacijah. Ena izmed njenih sklepnih ugotovitev je, da pregled vsebine in uporabe termina civilnovojaško sodelovanje, najpogosteje znanega kot CIMIC, pokaže, da znotraj sodobnih mirovnih operacij tako v vsebini kot uporabi tega pojma ni enotnosti. Pa ne le to, srečamo celo nasprotovanje sodelovanju na terenu, kar vidimo zlasti v razmerju med humanitarnimi organizacijami in vojaškimi silami.

Andreas Hauptmann Kaiser je pripravil članek z naslovom Enote Nemške vojske za gorsko bojevanje, $\mathrm{v}$ katerem nam podrobno predstavlja namen, organiziranost in delovanje nemških enot za gorsko bojevanje, s poudarkom na 23. brigadi gorske pehote in vaji Edelweiss 2015.

Bralci Sodobnih vojaških izzivov ste kot vedno vabljeni $\mathrm{k}$ branju in pisanju prispevkov. 


\section{EDITORIAL}

\section{ARMED FORCES TODAY}

The year 2016 is a very important year for Slovenia. It is the year in which we commemorate our decision made 25 years ago to take an independent and democratic path, a path of decisions and changes. Since then, a lot has occurred. We have gained a number of experiences, we are more skilled and more knowledgeable. On the occasion of important anniversaries, such as this one, we usually take time to appreciate the milestones which marked the path we have walked. But what is even more inspiring is that these anniversaries and historical memories can be used as a source of ideas for the future.

The editorial board of Contemporary Military Challenges set a goal to honour the twenty-five years of Slovenia's independence with this year's last number titled Republic of Slovenia - first 25 years of independence in the international security environment. In this issue we would like to include papers which reflect the knowledge of Slovenian history and experience in the field of security, defence and military, and are at the same time enriched with current topics and suggestions for Slovenia's future path in the international security environment.

The third issue which will see the light of day in October will be titled International security community at a crossroads. We expect papers on the novelties introduced by the NATO Summit in Warsaw and the new European Defence Strategy, papers regarding different current security risks and in particular papers on possible responses to such risks. The most important element of response to security risks is prevention in the form of anticipation, planning, formation and coordination of strategies and, finally, their successful realization.

The second issue in our eighteenth volume will be titled Women, peace and security on the $15^{\text {th }}$ anniversary of the UN Security Council Resolution 1325. In the past, two collections of scientific papers on women in the armed forces were published 
in Slovenia. The first was published by the Ministry of Defence in 1995, while the second is the result of cooperation of the Ministry of Defence and the Faculty of Social Sciences. However, this will be the first issue of Contemporary Military Challenges devoted specifically to this subject.

The title of this year's first issue is Armed forces today. With these selected titles and topics we will dedicate this year's issues to the past, the present, the future, to women, and to peace and security.

The first paper in the issue devoted to the armed forces today is titled Theoretical aspects of the relationship between strategy and defence planning in the securitydefence and military fields. Pavel Vuk says that "/.../ a state's investment in the development of strategic thought, planning knowledge and skills should not be the subject of calculations regarding the resources invested, but the subject of long-term investment into the development of the thinking processes, ideas about future military objectives, warfare concepts and future possibilities of the armed forces". He believes that strategy and defence planning are rightfully placed among the most important and at the same time most challenging activities of every state.

Mehmedin Tahirović and Olivera Injac present the Development of the defence system of Montenegro. In their opinion, each state has its own strategic reasons for and particularities in the search of the best model for the protection of its security. They continue with the thought that reforms and the construction of all elements of Montenegro's national security during the accession process to Euro-Atlantic structures, especially the defence system, are much cheaper and that the level of their effectiveness is much higher.

Roving defence attachés: advantages and disadvantages is the title of the paper in which Gregor Zupan highlights the working principles of defence attachés who, due to the reduction of finances and the influence of modern technologies, have mostly been assuming posts of resident or roving defence attachés in recent years. In his paper, the author reflects the positive and negative aspects of both functions, especially from the aspect of the diplomatic career path development.

Vinko Vegič writes about the Emergence and conceptualization of hybrid warfare. $\mathrm{He}$ raises the issue of defining the concept of hybrid warfare in general and on the example of Ukraine and the so-called Islamic State, and defines its basic characteristics. Later in the paper, the author addresses the possibilities and issues of confronting hybrid warfare, and stresses the necessity to reflect on what the new strategic reality, currently manifested in the phenomenon of hybrid warfare in the Eastern and Southern outskirts of NATO (Ukraine, Syria and Iraq), is bringing to Slovenia's security environment.

Echelonment of fires and indirect fire systems in the Slovenian Armed Forces is the title of the topic addressed by Viktor Potočnik. According to the author, the 
purpose of this paper is simple: to form a standpoint of the Slovenian Armed Forces regarding the role and the task of systems providing indirect fires for fire support at the tactical level, all the way from platoon to brigade level. He explains the concept of the echelonment of fires and its significance for the success of fire and manoeuvre in the battlefield. Was he successful and how did he do it? You can read more about it in his paper.

Civil-military cooperation in general, especially in NATO and the European Union, and the particularities of such cooperation among the armed forces were the focus of Maja Garb in her paper titled Development of the term and the concept of civilmilitary cooperation and coordination in peace operations. One of her conclusions is that the overview of the contents and use of the civil-military cooperation term, better known as CIMIC, shows that in the context of modern peacekeeping operations both the contents and its use are ambiguous. Moreover, there are contradictions regarding cooperation in the field, which is especially evident in the relationship between humanitarian organizations and military forces.

Andreas Hauptmann Kaiser prepared a paper titled The German armed forces mountain troops in which he presents the purpose, organization and functioning of the German mountain warfare units in detail, with special emphasis on the 23rd Mountain Infantry Brigade and the Edelweiss 2015 exercise.

As always, readers of the Contemporary Military Challenges are kindly invited to read the papers and submit their own. 


\title{
TEORETIČNI VIDIKI ODNOSA MED STRATEGIJO IN OBRAMBNIM PLANIRANJEM NA VARNOSTNO- OBRAMBNEM IN VOJAŠKEM PODROČJU
}

\author{
THEORETICAL ASPECTS OF THE RELATION \\ BETWEEN THE STRATEGY AND DEFENCE \\ PLANNING IN SECURITY, DEFENCE AND \\ MILITARY FIELDS
}

Povzetek Poznavanje in razumevanje teoretičnih značilnosti strategije in obrambnega planiranja je nujen predpogoj za premišljeno obvladovanje kompleksnega procesa uresničevanja političnih ciljev države na varnostno-obrambnem in vojaškem področju ter oblikovanje skladnega načrta (strategije ali obrambnega plana) za premostitev vrzeli med aktualno realnostjo in želeno prihodnostjo. Zato strategijo in obrambno planiranje upravičeno uvrščamo med najpomembnejše in hkrati tudi najzahtevnejše aktivnosti vsake države. Izvajanje strategije in obrambnega planiranja sta neločljivo povezana procesa, nujna za prihodnjo nacionalno varnost ter zagotavljanje obrambne sposobnosti države za soočenje $\mathrm{z}$ najbolj verjetnimi nevarnostmi prihodnosti. Naložba države v razvijanje strateške misli ter planskega znanja in veščin ne bi smela biti predmet kalkulacije vloženih sredstev, ampak predmet dolgoročne investicije $\mathrm{v}$ razvijanje miselnih procesov, zamisli o prihodnjih vojaških ciljih, konceptih bojevanja in prihodnjih opcijah oboroženih sil. Zavedanje političnih odločevalcev o pomenu dolgoročnega, skladnega in kontinuiranega razvoja obrambne sposobnosti države ne bi smelo biti vprašanje, temveč dejstvo, glede na to, da varnosti ni mogoče dobiti neposredno. To pomeni, da se mora državno vodstvo spoprijeti s paradoksom priprave na vojno tudi v miru, če želi zagotavljati državljanom pričakovano visoko stopnjo nacionalne varnosti in ohraniti mir.

\section{Ključne Strategija, obrambno planiranje.}

besede

Abstract Knowledge and understanding of the theoretical characteristics of strategy and defence planning are a prerequisite for sound management of the complex process of implementing national political goals of the state in security, defence and military fields and of developing a coherent plan (strategy or defence plan) to bridge the gap between the current reality and the desired future. Therefore, 
strategy and defence planning are rightly considered to be the most important and the most demanding activities in each country. The implementation of the strategy and defence planning are inextricably linked processes indispensable for future national security and ensuring the defence capability of a country to deal with the most likely future threats. National investments in the development of strategic thinking and planning skills and knowledge should not be subject to calculation of invested funds, but subject to long-term investment in the development of thought processes, ideas about the future of military objectives, concepts of warfare and future options of the armed forces. The awareness of decision-makers on the importance of the long-term, consistent and continuous development of the defence capacity of a country should not be an issue, but a fact, since security cannot be obtained directly. This means that the state leadership should deal with the paradox of preparing for war in peace, if it is to provide citizens with a high level of national security and preserve peace.

\section{Key words Strategy, defence planning.}

Uvod Pojem strategija se danes pogosto uporablja v vsakdanjem življenju in medijih, povezujejo pa ga od vizije, plana, koncepta do akcijskega načrta, in sicer na vseh ravneh družbenega življenja. Največkrat je povezan s tem, »kaj« želimo narediti in je $\mathrm{z}$ vidika razumevanja teoretičnega pojma strategije neprimeren, saj ne vključuje narave kompleksnosti prave strategije niti strateškega razmišljanja. Tako se pojem strategije usmeri le na ideje, ki pa niso podprte s potrebnim razmišljanjem ali razvojem. Takšna raba pojma ne postavlja ustrezno ločnice med strategijo in planiranjem, saj se strateške možnosti omejijo na kratkoročne planske predpostavke, kar pa omejuje fleksibilnost strateškega razmišljanja.

$\mathrm{Z}$ razumevanjem teorije strategije lahko razumemo njeno kompleksnost in logiko. Teorija strategije razvija terminologijo in definicije ter preizkuša hipoteze in metode, ki bi lahko bile uporabljene pri razvoju teorije (Yarger, 2006, str. 1). Teorijska vrednost ni v predpisih, ampak v tem, kako razširiti in usmeriti razmišljanja. Tudi Clausewitz (2004, str. 82-83) izpostavlja, da mora biti teorija opazovanje in ne nauk. Opazovanje je bistveni del vsake teorije, je analitična raziskava predmeta, ki vodi do natančne seznanjenosti z njim oziroma do njegovega poznavanja. Teorija strategije je torej način razumevanja, kako lahko razvijamo perspektive in pristop za oblikovanje in izbor alternativnih možnosti v kompleksnem in spreminjajočem se varnostnem okolju, s fokusom razmišljanja na »kako« in ne na »kaj« ter v povezovanju možnosti in poti, ki bi lahko bile razumne in izvedljive. Zato strategija ni niti preprosta niti lahka, čeprav strategi vedno iščejo načine, da strateško logiko razlagajo preprosto in razumljivo. Operacionalizacija in konkretizacija strategije oziroma njenih strateških ciljev potekata skozi proces planiranja.

Obrambno planiranje je oblika strateškega planiranja in je eden izmed najpomembnejših procesov, s katerim se zagotavljajo prožnost, prilagodljivost in 
pripravljenost obrambnih zmogljivosti za spoprijemanje z negotovostmi v svetu. Gre za kompleksno področje, ki ga dodatno otežuje še mnogovrstnost strateških interesov in ciljev (izvajanje strategije), za katere se mora predvideti njihov potek razvoja v prihodnjem obdobju. Če bi se planiranje nanašalo samo na maksimiziranje pričakovanih koristi, bi bilo vse veliko manj kompleksno, vendar je tako kot strategija neločljivo povezano z negotovostjo. Države se srečujejo z različnimi tipi negotovosti, kar v končni fazi vpliva tudi na raznolikost oblikovanja vojaške strukture sil. Frühling Stephan (2014) pojasnjuje, da je obrambno planiranje upravljanje s tveganji v odnosu do negotove prihodnosti, in da je proces upravljanja s tveganji $\mathrm{v}$ bistvu zmeraj političen. Ne glede na to, kako lahko napredne metode ocenjevanja vplivajo na zmanjševanje negotovosti, ostaja dejstvo, da zaradi negotove in nejasne prihodnosti ni mogoče zanesljivo poznati njene nevarnosti. Zato se podobno kot strategija tudi obrambno planiranje zmeraj izvaja v kontekstu omejenosti.

Prispevek proučuje teorijo strategije, s poudarkom na odnosu med strategijo in obrambnim planiranjem ter njuno vlogo pri obravnavanju varnostno-obrambnih vprašanj. Današnji čas hitrih in nepredvidljivih sprememb in dinamičnosti sodobnega varnostnega okolja, ki se kaže v različnih oblikah varnostnih groženj in tveganj, zahteva močno zavedanje in odgovoren odziv države na te nevarnosti. Strategijo torej, ki bo usmerjala obrambno planiranje k pravočasnemu in zadostnemu načrtovanju obrambnih potreb države za učinkovito odzivanje na grožnje in tveganja varnosti. Obrambna varnost države je stalen proces, ki ne more biti podvržen vsakodnevnemu političnemu razpoloženju in občutku. Zato se mora obrambna sposobnost države in njenih zmogljivosti vseskozi graditi, izpopolnjevati in preoblikovati glede na strateška dogajanja v varnostnem okolju. Kredibilnost obrambne drže države je tako odvisna od številnih dejavnikov, najpomembnejši med njimi pa so poleg razpoložljivih virov tudi sposobnost strateškega razmišljanja, »dovolj dobra« strategija in razvit proces obrambnega planiranja.

Drugo osrednje vprašanje, s katerim se ukvarja prispevek, je negotovost, s katero se srečujejo strategi in obrambni planerji pri svojem delu, ter njihova usposobljenost za ocenjevanje in predvidevanje najbolj verjetnih nevarnosti prihodnosti. Razumevanje strateške logike in načel obrambnega planiranja je povezano tako z izobraževanjem oziroma izobraženostjo kot tudi zizkušnjami in intelektualno sposobnostjo strateškega razmišljanja posameznika. Razvijanje strateške misli ter planskega znanja in veščin sta neločljivo povezana in predstavljata za državo dolgoročno naložbo v razvoj varnostno-obrambnega področja, kot je varnost neločljiva strukturna prvina družbe in predstavlja temeljno vrednoto medčloveških odnosov.

\section{STRATEGIJA}

\subsection{Izvor besede, pomen, definicije}

Etimologija in semantika pojma strategija izhaja iz grških besed stratos (vojska) in ago (voditi), kar bi lahko v prevodu pomenilo umetnost vojskovanja (Javornik 
(ur.), 1998, str. 4117). Znana so tudi mnenja, da je ta pojem povezan z grško besedo strategema, ki pomeni ukano v vojni oziroma mojstrstvo, da se sovražnik napelje v zmotno presojo in ravnanje (Žabkar, 2003, str. 182).

Pomen pojma strategija se je z družbenim razvojem postopno spremenil in razširil. Če je bil ta pojem v prvotnem pomenu omejen na veščino uporabe vojske v vojni ali na veščino vojskovanja, je danes njen pomen razširjen in obsega znanost in veščino (teorijo in prakso) o pripravah in vodenju kriznih razmer in vojne ter o uporabi sile za doseganje političnih, ekonomskih in vojaških ciljev. Pri tem pa Žabkar (2003, str. 182-183) dodaja, da vključuje tudi uporabo politične, diplomatske, gospodarske, vojaške, psihološke, informacijske, znanstvene in druge sestavine državne (ali koalicijske) moči v miru, krizah in vojni.

Prisotnost besede strategija danes zasledimo na številnih področjih družbenega življenja, tudi v vsakdanjem govoru v smislu dolgoročnega načrta dejanj, potrebnih za reševanje problemov pri doseganju določenega cilja. Strategija torej v najširšem pomenu označuje temeljne podlage, postopke in načrte za smotrno in usklajeno uporabo sil, sredstev in drugih virov zaradi maksimalnega približanja postavljenim ciljem oziroma njihove uresničitve. Njen namen je uskladiti cilje in sredstva (Lubi (et al.), 1999, str. 11).

S strategijo se ukvarjajo v najvišjem političnem, državnem in vojaškem vodstvu. Kljub razširjenosti uporabe se pojem strategija še vedno najpogosteje uporablja na varnostno-obrambnem in vojaškem področju. Na teh področjih je strategija najbolj natančno opredeljena in ima lahko več pomenov: strategija kot znanstvena disciplina (teorija) ali strategija kot dejavnost (veščina) politično-vojaškega vodstva države (Lubi (et al.), 1999, str. 11-12).

Definicije pojma strategija imajo nekatere skupne značilnosti, pa tudi pomembne razlike. Definicije (slika 1), ki so jih podali Carl von Clausewitz, Von Moltke, Liddell Hart in Abdré Beaufré so zelo ozko opredeljene, saj povezujejo vojaško silo s cilji vojne. Te definicije izhajajo iz izvora besede strategija, kot so jo uporabljali vojskovodje v stari Grčiji. Definiciji Fosterja in Osgooda sta usmerjeni na širše pojmovanje moči, medtem ko Murray in Grimslay osvetljujeta dinamiko kakovosti procesa, povezano s formulacijo strategije. Sodobni pisci poudarjajo, da ima strategija uporabnost tako v miru kot v vojni. Strategija vključuje več kot samo proučevanje vojn in vojskovanj. Je uporaba vojaške moči za doseganje političnih ciljev oziroma je teorija in praksa uporabe ter grožnja uporabe vojaške sile za dosego političnih namenov (Gray, 1999). Še vedno pa velja, da velika ali splošna strategija (angl. grand strategy) predstavlja najširši koncept, ki vključuje koordinacijo in usmeritev vseh virov države ali več držav skupaj (koalicije držav) za dosego političnih ciljev. Vrhunski doseg te strategije je po Žabkarju (2003, str. 183) uresničitev nacionalnih ciljev z grožnjo uporabe vojaške sile, ne da bi za to bila uporabljena. 
Omeniti velja še Henryja Ecclesa (Boorman, 2009, str. 93), ki je opredelil strategijo kot celovito usmeritev instrumentov moči v nadzor položaja in prostora za dosego cilja. Yarger (2015) pravi, da se Ecclesova opredelitev strategije dotakne bistva strategije, ker je celovita, ker usmerja, njen namen je nadzor, in kar je bistveno, za njeno uresničevanje uporablja instrumente moči.

\begin{tabular}{|c|c|}
\hline \multirow{8}{*}{$\begin{array}{r}\text { Slika 1: } \\
\text { Definiranje } \\
\text { strategije (vir: } \\
\text { Baylis (et al.), } \\
2002 \text {, str. 4) }\end{array}$} & Strategija je uporaba boja za uresničitev smotra vojne (Carl von Clausewitz). \\
\hline & Strategija je praktična prilagoditev sredstev, ki so na voljo generalom za dosego ciljev vojne (Von Moltke). \\
\hline & Strategija je veščina distribucije in uporabe vojaških sredstev za dosego političnih ciljev (Liddell Hart). \\
\hline & $\begin{array}{l}\text { Strategija je veščina dialektike sile oziroma veščina dialektike dveh nasprotujočih si volj, ki uporabita silo } \\
\text { za reševanje sporov, zaradi katerih je prišlo do konfrontacije (André Beaufré). }\end{array}$ \\
\hline & Strategija je (v končni fazi) učinkovito uveljavljanje moči (Gregory D. Foster). \\
\hline & $\begin{array}{l}\text { Strategija je akcijski načrt, zasnovan za dosego cilja, vključno s sistemom ukrepov za njeno uresničitev } \\
\text { (J. C. Wylie). }\end{array}$ \\
\hline & $\begin{array}{l}\text { Strategija je proces stalnega prilagajanja spremenjenim pogojem in okoliščinam v svetu, v katerem } \\
\text { prevladujejo priložnosti, negotovosti in nejasnosti (W. Murray in M. Grimslay). }\end{array}$ \\
\hline & $\begin{array}{l}\text { Strategija je splošen načrt uporabe zmogljivosti oborožene prisile - v povezavi z ekonomskimi, } \\
\text { diplomatskimi in psihološkimi instrumenti moči - da bi z odkritimi in prikritimi sredstvi najučinkoviteje } \\
\text { podprli zunanjo politiko (Robert Osgood). }\end{array}$ \\
\hline
\end{tabular}

Poenostavljeno bi lahko rekli, da je pojem strategije tehtanje ciljev, konceptov in virov znotraj sprejemljivih meja tveganj, z namenom, da bi prišli do najboljših mogočih rezultatov in rešitev. Obrambni slovar vojaške terminologije ZDA (Joint Publication 1-02, 2010, 237) opredeljuje strategijo kot znanost in veščino razvijanja ter uporabe instrumentov nacionalne moči v sinhronizirani in integrirani obliki za dosego operativnih, nacionalnih in večnacionalnih ciljev. Obe opredelitvi sta sicer uporabni, vendar nobena od njiju ne izraža popolne vloge in kompleksnosti strateške misli na najvišji državni ravni. Na tej ravni je namreč strategija znanost in veščina razvijanja in uporabe politične, ekonomske, družbenopsihološke, informacijske in vojaške moči države, skladne s političnimi smernicami, s katerimi se ustvarjajo učinki za zaščito in uresničevanje nacionalnih interesov v strateškem okolju ${ }^{1}$. Takšna strategija teži k sinergiji ciljev, konceptov in virov, s katerimi se povečujejo verjetnosti političnega uspeha. Hkrati gre za proces, ki omogoča racionalno in postopno prilagoditev okoliščinam, pa če se te pojavijo ali ne. V strategiji se to doseže z opredelitvijo pojmov »ends«, »ways« in »means«, ki bodo podrobneje razloženi v nadaljevanju.

Strateško okolje pri tem predstavlja prostor, v katerem prihaja do interakcij med državnimi voditelji in drugimi akterji, ter ustvarja priložnosti za blaginjo države (Yarger v Bartholomees, 2010, str. 53). 
Ker strategija predstavlja most med političnimi cilji in vojaškimi zmogljivostmi, je treba poznati tako nacionalno politiko kot tudi vojaške operacije, pri čemer se politični, ekonomski, psihološki in vojaški dejavniki prekrivajo. Pri tem pomeni vojaški nasvet enega izmed pomembnejših sestavin strategije. Henry Kissinger pravi, da z ločitvijo strategije in politike posledično vplivamo na škodo obeh. Takšno dejanje lahko privede do zlorabe uporabe vojaške moči ter zavajanja diplomacije (Kissinger, 1957 v Baylis, 2002, str. 3).

Strategija se torej mora proučevati iz perspektive interdisciplinarnosti, da bi lahko razumeli njeno dimenzijo. Za to pa je treba poznati in razumeti politiko, ekonomijo, psihologijo, sociologijo, geografijo pa tudi tehnologijo, strukturo vojaških sil in taktiko. Strategija je pragmatična in tudi praktična aktivnost. Bernard Brodie ${ }^{2}$ (1973) je izpostavil, da je teorija strategije teorija dejanja, proučevanje, »kako« nekaj narediti, da se na najučinkovitejši način dosežejo zastavljeni cilji. Pri tem se je treba zavedati, kot pravi Gray (1999), da je proučevanje strategije nepopolno, če ni upoštevana katera izmed interdisciplinarnih ved.

Poleg omenjenega je treba izpostaviti uporabo pojma strategija na varnostnoobrambnem in vojaškem področju še $v$ povezavi s poimenovanjem posameznih državnih dokumentov. V prispevku se bosta uporabljala predvsem naziva splošna strategija, kot sopomenka za veliko (angl. grand strategy), nacionalno (angl. national strategy) ali nacionalnovarnostno strategijo (angl. national security strategy), in vojaška strategija. Pri takšnem pojmovanju se s splošno strategijo ukvarjajo najvišja državna vodstva, ki imajo v svojih rokah vse vzvode državne moči, in s katero se usmerjajo politična, vojaška, gospodarska, diplomatska in preostale parcialne strategije (več o tem Žabkar, 2003, str. 183, Lubi (et al.), 1999, str. 12-15).

\subsection{Razumevanje strategije - nekateri poudarki}

Strategija se je razvila iz temeljitega proučevanja strateških situacij in poznavanja narave strateškega okolja. Strateško okolje obsega naravne in metafizične lastnosti ter notranjo in zunanjo komponento. Zunanjo komponento predstavlja mednarodno okolje, ki jo sestavljajo fizično geografsko okolje, mednarodni sistem in drugi zunanji akterji ter njihove kulture, vrednote in dejanja. Notranje okolje sestavljajo notranje značilnosti države, njeni akterji, volivci, institucije in organizacijska pravila. S stabilnostjo znotraj okolja se zmanjšuje potreba po strateški izbiri, medtem ko nestabilnost znotraj okolja sili k sprejemu nove strategije. Naravo strateškega okolja bi lahko opredelili kot interaktiven, kompleksen sistem sistemov. Pri tem je pomembno, da je strategija skladna z naravo strateškega okolja (Yarger, 2006,

\footnotetext{
Bernard Brodie je bil po koncu druge svetovne vojne eden izmed glavnih zagovornikov oblikovanja strateških študij kot predmeta, pri katerem bi se proučevala strategija kot znanstvena disciplina, bodisi pri obravnavi oboroženih sil ali širše. V članku »Strategy as Science« iz leta 1949 je pozival k metodološkemu pristopu pri študiju strategije. Strategija bi po njegovem mnenju morala biti prepoznana kot znanost pri reševanju praktičnih problemov. S tem je želel vnesti na znanstveno področje predvsem natančnost in sistematičnost pri analiziranju strateških zadev, temelječih na ugotovljivih spoznanjih, ki so tesno povezana z varnostnimi problemi in vojsko, ki je bila v tistem obdobju preobremenjena s taktiko in tehnologijo. Strateške študije so se tudi po njegovi zaslugi v 50. letih prejšnjega stoletja vendarle razvile v znanstveno disciplino.
} 
str. 8). Strateg mora biti sposoben izločati neproduktivne elemente ter zagotoviti, da strategija upošteva kriterije sprejemljivosti tako v nacionalnem kot mednarodnem prostoru.

Vsaka strategija vnaša spremembe v strateško okolje (ogroža obstoječe ravnotežje), čeprav je njen namen samo ohranjanje položaja »status quo«. Zato se upravičeno postavlja vprašanje, ali je smiselno kaj storiti oziroma kakšne bi bile pri tem posledice. Strategija lahko predvidi prihodnost s seznanjanjem s pravimi cilji, ne more pa predvideti prihodnosti z absolutno gotovostjo, niti dosežkov postavljenih ciljev, niti natančnih posledic dosežkov ali neuspehov. Strateg je tisti, ki mora vedeti, ali postavljeni cilji upravičujejo tveganje začetih dejanj, za kar pa mora poznati in upoštevati tudi mogoč odziv drugih akterjev (Yarger, 2006, str. 8). Strategija torej ustvarja varnostno dilemo ${ }^{3}$ za stratege in druge vključene akterje.

Ključna sestavina strateške sposobnosti je razmišljanje $\mathrm{v}$ času. To pomeni sposobnost, predvideti kontinuiteto strateških izbir ter posledice njihovih učinkov za prihodnost. Strateška izbira mora imeti kontinuiteto s preteklostjo, zato se morajo pri oblikovanju strategije upoštevati preteklost in zgodovinska spoznanja iz razvoja strateškega okolja ${ }^{4}$. Strateg ekstrapolira spoznanja v prihodnost na podlagi poznanih pojavov in trendov v strateškem okolju. Na podlagi tega strateg oblikuje paradigmo izbire, ki je potreben element za načrtovanje želene prihodnosti.

Z osredotočenostjo na primarne vzroke postane strategija prilagodljiva in prožna pri poudarjanju strateških ciljev in pri zagotavljanju hierarhične ravni. Yarger (2006) pravi, da mora strategija upoštevati izkušnje in biti dovolj splošna v svoji sestavi, da se lahko prilagodi nenačrtovanim dogodkom in ukrepom nasprotnikov. V primerjavi s planiranjem, ki temelji predvsem na vzročno-posledični povezavi, je strategija proces stalnega prilagajanja spremenljivim okoliščinam v svetu, v katerem prevladujejo priložnosti in negotovosti.

V celotni strategiji prevladujejo politični cilji, kar poudarja tudi Clausewitz (2004, str. 28), ki pravi, da je »vojna samo nadaljevanje politike z drugimi sredstvi «5. Politika z jasno artikulacijo usmeritev izraža cilje vlade, dosego ciljev pa ji omogoča

\footnotetext{
3 Varnostno dilemo je razvil John Hertz v 50. letih prejšnjega stoletja. Bistvo njegove ideje se kaže v tem, da vsak napor posamezne države za uresničevanje varnostnih potreb v kvazianarhičnem mednarodnem okolju druge države zaznajo kot vir ogrožanja njihove varnosti. Zato je krepitev obrambnih sposobnosti neke države lahko grozeča za druge države, saj jih čutijo kot napadalno in ne kot obrambno ravnanje.

${ }_{4}$ V primernem zgodovinskem času imajo lahko na primer majhna dejanja velik strateški učinek. Če je izbran napačen čas, za rezultat potrebujemo zelo veliko prizadevanja in nesorazmerno porabo virov. Strateg se ukvarja tako s kontinuiteto in spremembami kot tudi z zgodovino in prihodnostjo. Poznavanje zgodovine omogoča postavitev pravilnih vprašanj za iskanje prihodnje perspektive glede na razpoložljive strateške izbire (Yarger, 2006, str. 14).

5 Clausewitz kot teoretik ne izhaja iz identifikacije vojne kot političnega instrumenta, temveč iz zavedanja, da politika prodre v vse vojaške ravni. Da je vojna v funkciji politike, je bilo kardinalu Richelieuju (1585-1642) znano že v 17. stoletju, ko je za uporabo topov uporabil besede »Ultima Ratio« oziroma skrajno sredstvo. Kardinal Richelieu je bil kot francoski zunanji minister mojster premetenosti, zavedal se je, da se vojne ne dobijo samo na bojnem polju, ampak tudi s politiko, s pogajanji. Ta pogled na vojno kot skrajno sredstvo se je ohranil vse do moderne dobe (Moran v Baylis (et al.), 2002, str. 18).
} 
uporaba instrumentov moči. V strategiji se torej politika kaže zlasti z opredelitvijo ciljev, razpoložljivostjo virov in drugimi omejitvami. S cilji strategije, ki imajo vselej politični namen, se tako zagotovijo namen, smer in upravičenost dejanj. Yarger (2006, str. 7) meni, da ima razvoj strategij pomemben vpliv tudi na politiko, ki se mora prav tako prilagajati realnosti strateškega okolja in omejenosti moči. Tako oblikovana politika zagotavlja, da strategija sledi primernim ciljem, medtem ko strategija seznanja politiko o tem, kaj je mogoče.

\subsection{Strategija kot znanost in veščina}

Omenili smo že, da je o strategiji mogoče govoriti kot o znanstveni disciplini (teoriji) in kot o dejavnosti (veščini). Pri obeh strategijah razlikujemo predvsem med splošno in vojaško strategijo.

Pri obravnavi strategije kot znanstvene discipline pomeni splošna strategija sistem znanstvenih spoznanj in znanost, ki proučuje najpomembnejša vprašanja, povezana s teorijo in prakso obrambne dejavnosti države, zlasti uporabo njenih političnih, gospodarskih, psiholoških, vojaških in drugih sredstev pri uresničevanju nacionalnih obrambnih ciljev zaradi zavarovanja nacionalnih interesov v miru in vojni. Kot veščina je splošna strategija praktična dejavnost najvišjih organov političnega vodstva države, povezana z najpomembnejšimi vprašanji obrambe države, predvsem s pripravljanjem na vojno in njenim morebitnim izvajanjem. Bistvo strategije kot dejavnosti je, da na temelju opredeljenih nacionalnih interesov in presoje zunanje ogroženosti teh interesov določi strateške cilje, zbere razpoložljiva sredstva in ob upoštevanju tveganj in stroškov določi strategijo za uresničitev postavljenih ciljev (Lubi (et al.), 1999, str. 12-14).

Vojaška strategija kot znanstvena disciplina proučuje praktično uporabo oboroženih sil za doseganje ciljev (Žabkar, 2003, str. 183), ki jim jih je zastavila splošna strategija. Z vojaško strategijo se proučujejo najpomembnejša vprašanja, povezana s teorijo in prakso pripravljanja in izvajanja celotnega oboroženega boja kot bistvene prvine vojne in uporabo drugih oblik vojaške sile (ali grožnje z vojaško silo) zaradi uresničevanja vojaških in obrambnih ciljev države. Vojaška strategija kot veščina je praktična dejavnost najvišjega vojaškega vodstva države, ki se nanaša na priprave za izvajanje in uporabo ter izvajanje oboroženega boja in na uporabo drugih oblik vojaške sile ali grožnje $z$ vojaško silo zaradi uresničevanja vojaških in obrambnih ciljev države. Vojaška strategija, omejena na vojaško prvino obrambe, se ukvarja z iskanjem optimalnega razmerja med sredstvi in cilji ter optimalnega načina uporabe razpoložljivih sredstev zaradi uresničitve postavljenih ciljev (Lubi (et al.), 1999, str. 12-14).

Strategija se razlikuje od veščine vojskovanja in taktike v funkcionalnem, časovnem in geografskem vidiku. Taktika je iz vidika funkcionalnosti in časa domena boja, spopada večje ali manjše razsežnosti v krajšem časovnem obdobju. Veščina vojskovanja je domena vojskovanja, vojaške operacije, ki traja daljši čas. Strategija pa je domena vojne, ki obsega širok spekter konfliktov med narodi in drugimi 
mednarodnimi akterji. Taktika se torej ukvarja z delčki, veščina vojskovanja $\mathrm{s}$ kombinacijo teh delčkov, strategija pa s kombinacijo teh kombinacij. Z vidika geografije se taktika nanaša na manjši prostor, veščina vojskovanja obsega operativno raven, torej širši prostor $\mathrm{z}$ regionalno usmerjenostjo, medtem ko strategija obsega celotno vojskovališče oziroma na območje operacije gleda globalno. Časovni horizont je večji na strateški kot pa na operativni oziroma taktični ravni (Yarger, 2006, str. 13).

\subsection{Hierarhičnost in celovitost strategij}

Politično vodstvo si zagotavlja in ohranja nadzor ter vpliv nad instrumenti moči s hierarhično strukturo strategij. Tako se usmeritve strategije stopničasto prenašajo z nacionalne na nižje ravni. Na splošno strategija izhaja $\mathrm{z}$ vrha kot posledica neke velike ali splošne strategije, za katero ni nujno, da je javno dokumentirana ter se hierarhično in po načelu stopničenja ${ }^{6}$ prenaša na druge parcialne strategije in politična stališča do specifičnih zadev. Splošne strategije (velike, nacionalne ali nacionalnovarnostne) vsebujejo splošne cilje in usmeritve, ki omogočajo uporabo vseh instrumentov moči. Z nacionalno politiko se zagotavljajo splošne strateške usmeritve za politično vodstvo, ki izhajajo iz nacionalnih interesov in se nanašajo na specifično strateško okolje. Na podlagi splošne strategije se izdelajo hierarhično nižje področne strategije (Yarger, 2006, str. 11). Na varnostno-obrambnem in vojaškem področju tako obrambna kot tudi vojaška strategija izhajata iz splošne strategije in pomenita nadaljnjo podlago za izdelavo drugih, hierarhično nižjih razvojnih in doktrinarnih dokumentov na področju nacionalne varnosti.

Obrambni slovar vojaške terminologije ZDA (Joint Publication 1-02, 2010) opredeljuje hierarhično raven strategij na podlagi vojaškega elementa moči, in sicer loči (slika 2):

- veliko strategijo (angl. grand strategy), ki je hierarhično najvišji strateški dokument na področju nacionalne varnosti in obsega nacionalno vizijo razvoja, uporabe in koordinacije vseh instrumentov nacionalne moči, potrebnih za dosego ciljev velike strategije, ohranitev nacionalne varnosti, ekonomske blaginje in nacionalnih vrednot;

- strategijo nacionalne varnosti (angl. national security strategy), ki izhaja iz velike strategije ali nacionalne strategije, je znanost in veščina razvoja, uporabe in koordinacije instrumentov nacionalne moči (diplomatskih, ekonomskih, vojaških in informacijskih) za dosego ciljev, ki prispevajo k nacionalni varnosti;

\footnotetext{
Načelo stopničenja je načelo, po katerem dokumenti, ki so po vsebini bolj podrobni in specifični, izhajajo iz dokumentov, ki so po vsebini bolj splošni in praviloma zajemajo tudi daljše časovno obdobje.
} 
- nacionalno vojaško strategijo ${ }^{7}$ (angl. national military strategy), ki je znanost in veščina distribucije in uporabe vojaške moči za dosego nacionalnih ciljev v miru in vojni, ki jih je oboroženim silam zastavila velika oziroma nacionalnovarnostna politika;

- strategijo vojskovališča (angl. theater strategy) - je znanost in veščina razvijanja integriranih strateških konceptov in postopkov za zaščito ciljev nacionalne, zavezniške ali koalicijske varnostne politike in strategije z uporabo sile ali njene grožnje, ne da bi bila za to uporabljena znotraj vojskovališča.

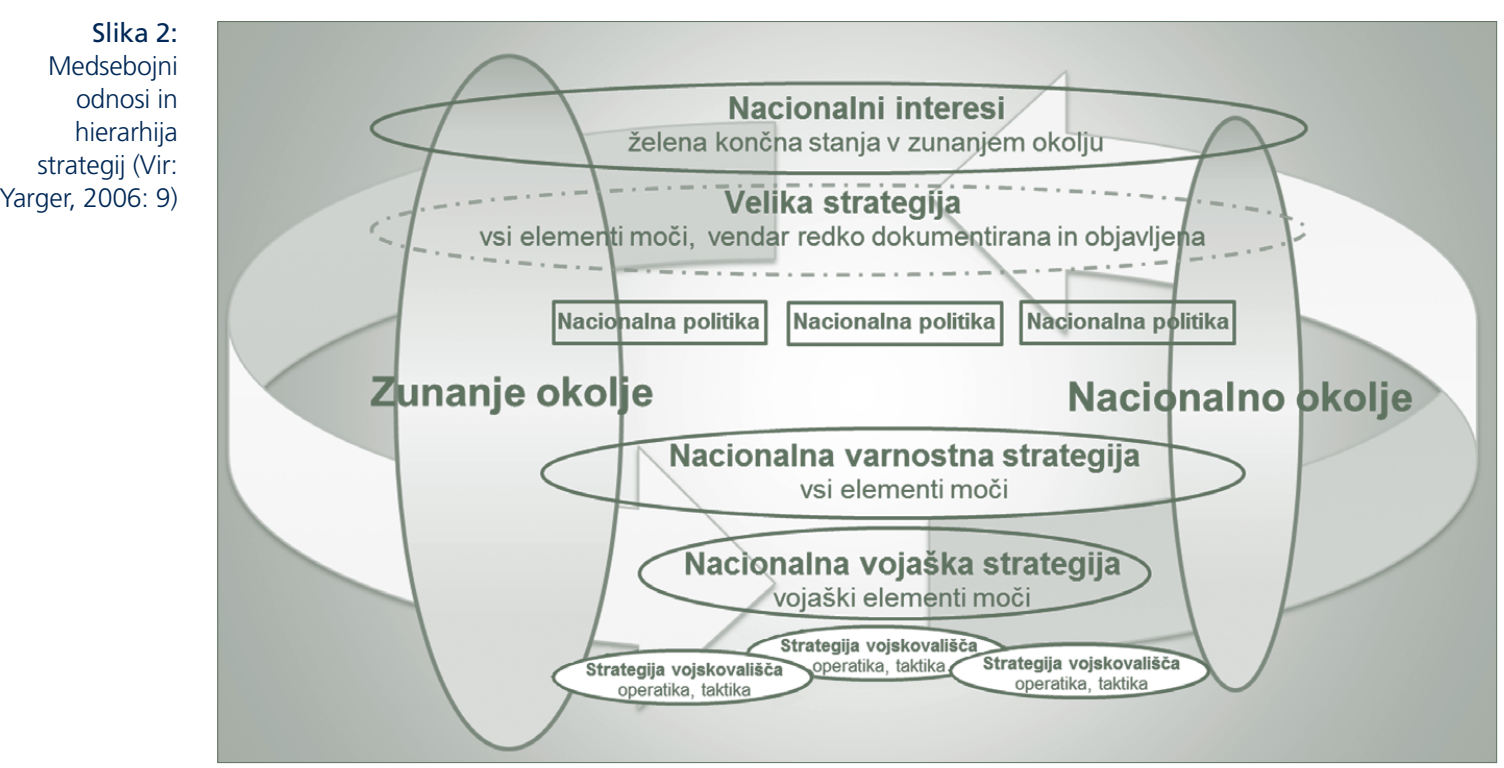

Raven in vrste strategij obsegajo različna področja družbenega življenja, s čimer se zagotavljata hierarhičnost in celovitost. Tako se pri oblikovanju strategije proučijo notranji in zunanji dejavniki na vseh ravneh ter horizontalna in vertikalna integracija strategije. Strateg mora torej razmišljati celovito in tudi celovito poznati okoliščine in dogajanja v strateškem okolju, da lahko objektivno oceni situacijo ter prednostno razvrsti izbire glede na učinke, ne glede na to, ali so pri tem akterji prijateljski, sovražni ali neopredeljeni. Strateg mora poznati tako celoto kot tudi notranje

\footnotetext{
Osnovni predmet vojaške strategije je oboroženi boj. Oblike in vsebine vojaškega boja, ki jih strategija proučuje, so kampanje (celotnost vojaških operacij v določenem času in področju) in sistemi kampanj vseh zvrsti oboroženih sil, $v$ vseh etapah in $v$ vseh fazah vojne. Hierarhično je podrejena splošni strategiji in obravnava oboroženi boj na hierarhični ravni sistema kampanj; to ji daje določeno avtonomijo, ker ji omogoča, da pred sprejetjem odločitev o uporabi oboroženih sil seznani splošno strategijo z zmogljivostmi vojaške strategije. S tem je dosežen dialog med obema strategijama, ki praviloma poteka v Svetu za nacionalno varnost med nosilci posameznih resorjev. Splošna strategija mora zato poznati realne sposobnosti nacionalne vojaške strategije, da ji ne zada neuresničljive naloge (več o tem Žabkar, 2003, str. 182-190).
} 
organizacijske posebnosti in vire ter njihov vpliv na okolje. Dobra strategija ni nikoli razvita po delih ali v izolaciji (Yarger, 2006, str. 8). Odgovornost za strategijo na vseh ravneh in področjih je $\mathrm{v}$ rokah političnega vodstva, kar jim hkrati omogoča tudi ohranjanje nadzora nad kompleksnim procesom (Yarger v Bartholomees, 2010, str. 53). Hierarhičnost strategij z logičnim in hierarhičnim načinom prenosa odgovornosti znotraj vodstva omogoča torej tudi učinkovit razpon nadzora nad strategijami in njihovim uresničevanjem.

Iz strategije mora biti razvidno, kaj želimo doseči in zakaj - strategija ne sme biti oblikovana tako, da bi izpostavljala politični ali intelektualni vakuum. Strategija je osredotočena na doseganje želenih oziroma prednostnih ciljev, izbranih iz množice mogočih ciljev dinamičnega okolja, ter daje usmeritve za uporabo instrumentov moči za dosego specifičnih ciljev (Yarger, 2006, str. 9). Strateg mora znati analizirati in razumeti želeno končno stanje v kontekstu strateškega okolja (notranjega in zunanjega), da bi lahko razvil primerne cilje, ki bi pripeljali do končnega stanja. Zato je pomembno, da pri snovanju strategije in njenih ciljev upošteva naravo strateškega okolja, usmeritve politike in nacionalne interese.

\subsection{Pomen »ends", "ways» in »means" v strategiji in planiranju}

Strategija s premišljeno kalkulacijo ciljev, konceptov in virov znotraj sprejemljivih meja tveganj predstavlja skladen načrt za premostitev vrzeli med aktualno realnostjo in želeno prihodnostjo. S tehtanjem teh razmerij strategija določa tudi, kako uporabiti vire za dosego želenih rezultatov v specifičnem strateškem okolju. V kontekstu države je strategija zaposlitev specifičnih instrumentov moči ${ }^{8}$ za dosego političnih ciljev države v dinamičnem in tekmovalnem strateškem okolju. Čeprav se strategija in planiranje med seboj razlikujeta, sta oba odvisna od okolja. Strategija se razlikuje od planiranja v svoji vsebinski in področni širini ter predpostavkah, kljub temu pa daje pomembne usmeritve in parametre za bolj natančno dolgoročno, srednjeročno in kratkoročno planiranje. Tako strategija kot planiranje uporabljata spremenljivke »ends«, »ways« in »means« pri oblikovanju uravnoteženih rešitev in sta omejeni s kriteriji ustreznosti, izvedljivosti in sprejemljivosti (slika 3).

\footnotetext{
Kotnik (2012, str. 11-20) poleg tradicionalnih instrumentov nacionalne moči (politični/diplomatski, ekonomski, vojaški in informacijski) izpostavlja še dodatnih šest (moralna moč, socialno-kulturna in ideološka moč, naravni viri, geostrateški položaj, obseg prebivalstva in kakovost prebivalstva). V sodobnem svetu, prepletenem s procesi internacionalizacije in globalizacije, je treba nacionalne moči držav ter instrumente, ki jih imajo na voljo za doseganje ciljev, obravnavati celovito. Pri tem Kotnik poudarja, da instrumenti nacionalne moči sami po sebi še ne predstavljajo cilja, ampak le orodja, ki so na voljo državni politiki pri zagotavljanju temeljnih dobrin za državo, družbo in njene prebivalce (dolgoročno stabilnost in varnost, demokracijo, pravice in ekonomski razvoj oziroma blaginjo).
} 


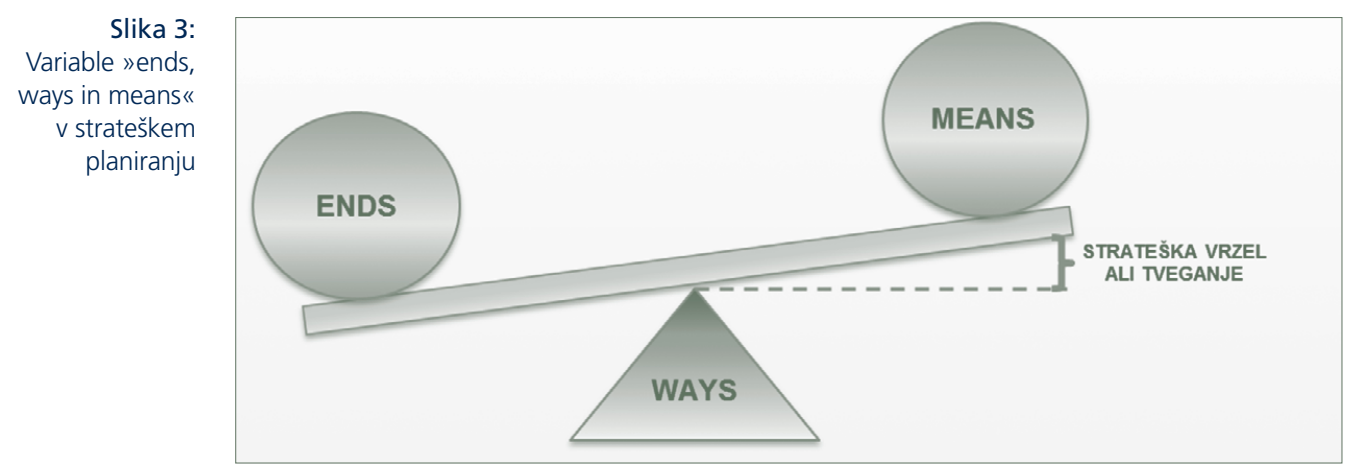

Yarger (2006, str. 6) izpostavlja pomen celovitosti strategije, katere namen je, da na skladen in optimalen način zagotovi uresničitev državnih interesov ${ }^{9} \mathrm{z}$ uporabo nacionalnih instrumentov moči ter doseže strateški učinek pri uresničevanju političnih ciljev. V tem smislu predstavlja strategija izbiro, ki omogoča napredek države v prihodnjem obdobju, ter načine za doseganje tega stanja.

Strategija torej pomeni, »kako« (angl. ways ali koncepti) bo najvišje državno vodstvo, skladno z nacionalno politiko, uporabilo razpoložljivo »moč« (angl. means ali vire) države, da bi lahko nadzirali okoliščine in prostor ter dosegli »cilje« (angl. ends), ki podpirajo državne interese. Strategija daje usmeritve za uporabo teh moči za dosego ciljev. Usmeritve so po naravi proaktivne in ne napovedovalne, saj se z njimi poskuša doseči nadzor nad okoljem, kar pa je ravno nasprotno od reagiranja na njega. Strategija namreč predpostavlja, da čeprav prihodnosti ni mogoče napovedati, lahko strateško okolje proučimo, ocenimo ter ga do določene mere predvidimo in vplivamo nanj. S primerno analizo se lahko identificirajo trendi, posledice, priložnosti in grožnje, ki pomembno vplivajo na odločitev države pri opredeljevanju in doseganju političnih ciljev. Tako strategija vpliva na potek razvoja strateškega okolja in pomeni protiutež nepremišljeni reakciji na ta razvoj. Zato Yarger (2015) trdi, da strategija ni krizno upravljanje, temveč je njegova antiteza. Do kriznega upravljanja namreč pride zaradi odsotnosti strategije oziroma ko je strategija neuporabna glede na dejanska pričakovanja. Strategija je torej proaktivna in anticipativna, ne pa tudi napovedovalna. Nekaterih elementov nacionalne moči ni mogoče natančno definirani niti razmejiti. Admiral Eccles je govoril o »megli strategije«, pri čemer je normalno pričakovati negotovosti, prekrivanja in nesoglasja na določenih področjih med različnimi predstavniki političnega vodstva (Jablonsky v Cerami (ur.), 2001, str. 152).

\footnotetext{
9 Kotnik (2012, str. 11-20) ugotavlja, da si v sodobnem, izrazito dinamičnem in spremenljivem varnostnem okolju, ki zahteva stalno medsebojno sodelovanje države in drugih akterjev, prizadevajo uresničevati svoje nacionalne interese prek odnosov vplivanja (mehka moč) ali prisile (trda moč), v katerih mora na bistroumen način mehka moč prevladati nad trdo močjo, kolikor dolgo je to mogoče in sprejemljivo.
} 
Art Lykke (po Yarger v Bartholomees, 2010, str. 48-50) je pojasnil model strategije s povezovanjem treh nožic stola, pri čemer strategija predstavlja seštevek »ends«, »ways« in »means« (slika 4). Če kateri izmed teh seštevancev ni v ravnotežju, pride do tveganja, ker strategija ni prilagojena okoliščinam.

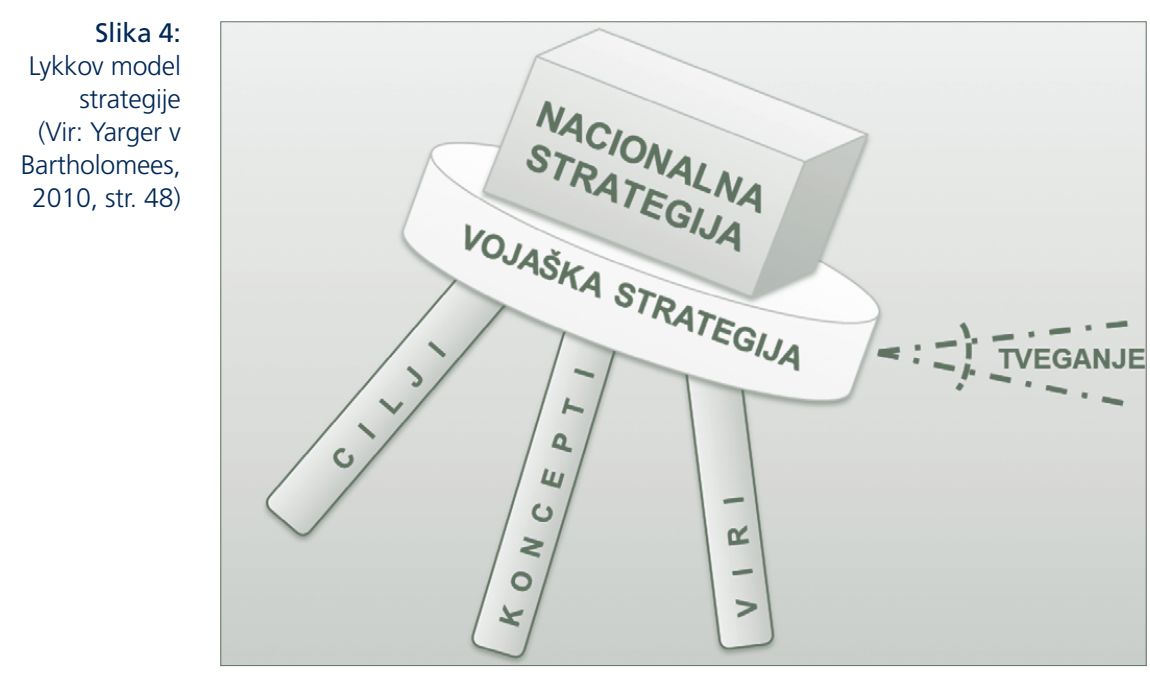

Model predstavlja tri ključna vprašanja za stratege: kaj in kako bi se moralo narediti ter kateri viri so potrebni za izvedbo. Lykke poudarja, da tveganje obstaja tudi, če bi krajšo nožico poskušali prilagajati okoliščinam. Z dodajanjem virov bi na primer lahko uporabili drugačen koncept ali celo spremenili cilje, lahko pa se to tveganje celo sprejme. Teorija je zelo jasna, veljavna strategija mora temeljiti na uravnoteženosti ciljev, konceptov in virov, drugače je tveganje za njeno uresničitev preveliko. Ta opredelitev in prikaz sta pomembna, ker omogočata skupno razumevanje, na podlagi katerega strategi komunicirajo med sabo. Pri tem pomeni:

- z »ends« (cilji) se pojasnjuje, »kaj« mora biti doseženo. Če jih dosežemo, prispevajo $\mathrm{k}$ želenemu končnemu stanju, opredeljenem $\mathrm{v}$ strategiji, ter ne nazadnje k uresničevanju nacionalnih interesov. »Ends« so izraženi z glagolom (npr. odvrniti vojno, podpirati regionalno stabilnost);

- z »ways« (strateški koncepti, postopki) se pojasnjuje, »kako« morajo biti doseženi cilji z uporabo razpoložljivih virov. Koncept mora biti razumljiv, da se lahko izdelajo planske smernice za tiste, ki zagotavljajo njegovo uresničitev in vire,

- $\mathrm{z}$ »means« (viri) se pojasnjuje, katere specifične vire uporabiti pri konceptih za dosego ciljev. Lahko so določni (sile, ljudje, oprema, finančna sredstva) ali pa nedoločni (voljnost, pogum, intelekt); 
- s tveganjem se pojasnjuje vrzel med doseženim in razpoložljivostjo konceptov in virov za dosego ciljev. Vrzel oziroma tveganje je vselej prisotno, saj nikoli ni mogoče zagotoviti zadostnih virov niti izdelati konceptov, ki bi zagotovili popoln uspeh v spreminjajočem se varnostnem okolju. Zato strategi pri izdelavi strategije želijo doseči čim manjšo stopnjo njenega tveganja oziroma uravnotežiti »ends«, »ways« in »means«.

Vsaka strategija bi morala biti po Lykkeju (prav tam, str. 50):

- ustrezna, da se z njenim dosegom uresniči želeno (povezano s cilji),

- izvedljiva, da se dejanja lahko uresničijo z razpoložljivimi sredstvi (povezano z viri),

- sprejemljiva, da posledice stroškov upravičijo pomembnost želenega (povezano z viri/koncepti).

Teorija strategije po Artu Lykkeju je pomemben prispevek k strateški misli. Njegova teorija spodbuja stratege $\mathrm{k}$ pravilni uporabi pojma strategija $\mathrm{z}$ uporabo modela strategije, ki temelji na ravnotežju spremenljivk »ends«, »ways« in »means«, ter tveganjem, ki ga je država pripravljena sprejeti.

V spreminjajočem se varnostnem okolju je v veliko primerih težko razlikovati, kateri izmed nacionalnih interesov so življenjski, saj se danes praktično vsi spoprijemajo z izzivi in grožnjami. Glede na to, da ni mogoče vzpostaviti takšnih oboroženih sil, ki bi bile sposobne zmanjšati tveganja povsod, kjer se pojavijo, je nujno, da se oblikujejo strateške prednostne naloge. Državno in politično vodstvo se morata spoprijeti s paradoksom priprave za vojno tudi v miru, če želi ohraniti mir. Dilema v tem paradoksu, ki dela strategijo v katerem koli obdobju težavno, je, da takšne pretirano dolge priprave dolgoročno oslabijo gospodarske, psihološke in politične elemente moči. »Ends«, »ways« in »means« bi morali biti uravnoteženi tako, da se naravne napetosti $\mathrm{v}$ nacionalnovarnostnih zadevah med notranjo in zunanjo politiko ohranjajo na minimumu, ob tem pa se nacionalni življenjski interesi še vedno lahko varujejo z minimalnim tveganjem. Rešitve, s katero bi se večina državnih voditeljev strinjala, pa ni preprosto doseči. V vedno bolj soodvisnem svetu, kjer se spremenljivke, s katerimi se strategi srečujejo znotraj paradigme »ends-ways-means«, eksponentno povečujejo, strategi še vedno niso nič bližje »kamnu modrosti«. Strategija ostaja tako še naprej najbolj težavna izmed vseh veščin (Jablonsky v Cerami (ur.), 2001, str. 153).

\section{IZZIVI OBRAMBNEGA PLANIRANJA}

\subsection{Načela obrambnega planiranja}

Nobeno vodstvo si ne more dovoliti, da bi bila njegova organizacija odvisna od naključij, saj bi morala biti ena izmed njegovih osnovnih nalog skrb za doseganje svojih ciljev. Ti temeljni cilji morajo imeti trajnejšo vlogo, in jih ni treba vsak dan prilagajati naključnim dogodkom v okolju, zato je vloga vodstva, da predvidi verjetna dogajanja $\mathrm{v}$ okolju organizacije in podrobneje določi cilje za določeno 
obdobje ter poti do njih. Govorimo o planiranju kot eni najpomembnejših funkcij vodij pri upravljanju organizacij. Njegovo bistvo je v razreševanju in preprečevanju problemov $^{10}$.

Pri upravljanju razpoložljivih virov in njihovi uporabi so zaradi omejitev in postavljenih temeljnih ciljev vedno prisotne težave, ki jih planiranje rešuje procesno. Z miselnim procesom se namreč vrednotijo alternative in tudi nevarnosti za organizacijo. Prisotnost alternativ določa potrebo, da se v procesu planiranja sprejemajo odločitve, ki imajo zaradi posledic v prihodnosti tudi določena tveganja. S planiranjem se sistematično zmanjšuje vpliv negotovosti v procesih odločanja, saj teži k temu, da je stopnja tveganja čim nižja, ne more pa se povsem izničiti.

Pfeiffer $(2008,104)$ opredeli obrambno planiranje kot celoto planskih aktivnosti, katerih glavni namen je vzpostavljanje in vzdrževanje zahtevanega obsega oboroženih sil in njihovih zmogljivosti v določenem časovnem obdobju, da se doseže njihova razpoložljivost za izvajanje dodeljenih nalog. Obrambno planiranje lahko opredelimo tudi kot celoto vseh področij obrambnega planiranja (ali disciplin) ${ }^{11}$, ki skupaj zagotavljajo sposobnost in pripravljenost oboroženih sil in podpornih struktur za prispevanje $\mathrm{k}$ nacionalni in širši varnosti. Osnovni cilj obrambnega planiranja je zagotoviti najboljšo kombinacijo sil, opreme in podpore za izvajanje strategij ob upoštevanju razpoložljivosti finančnih sredstev. Rezultat procesa obrambnega planiranja je uravnovešen in konsistenten razvojno-usmerjevalni plan, ki zagotavlja nenehni dvig sposobnosti obrambnega sistema glede na zastavljene cilje in strategijo.

Proces obrambnega planiranja poteka skladno z načeli:

- učinkovitosti - plani in programi morajo imeti določeno časovno trajnost, da se dosegata vzdržljivost in učinkovitost zmogljivosti. Plan je lahko dosežen, če se vlada obveže za dosledno uresničevanje sprejetega plana, če plan upošteva celoten življenjski cikel stroškov in če je obrambni proračun porabljen najbolj učinkovito (Le Rouf, 2002, str. 10);

- celovitosti in povezanosti - celovito izpolnjevanje namena, poslanstev in nalog je načelo, po katerem so prizadevanja na vseh področjih obrambnega planiranja usmerjena $\mathrm{v}$ doseganje skupnih ciljev in učinkov delovanja:

- realnosti - obseg planiranja organizacijskih, kadrovskih in materialnih potreb za doseganje zahtevane sposobnosti obrambnega sistema mora biti usklajen $\mathrm{z}$ razpoložljivimi viri;

\footnotetext{
${ }_{10}$ Planiranje si torej vnaprej zamišlja nastanek morebitnih težav in jih poskuša vnaprej preprečiti. Kljub planiranju prihaja do težav, ki pa so manjše, kot če planiranja ne bi bilo (več o tem Rozman (et al.), 1993, str. 76-77).

${ }^{\prime \prime}$ Natov proces obrambnega planiranja obsega sedem različnih področij oziroma disciplin planiranja, in sicer planiranje sil, virov, oborožitve, logistike, poveljevanja in kontrole (C3 sistemi), civilno-krizno planiranje ter jedrsko planiranje. Med podporna področja obrambnega planiranja spadajo še zračna obramba, upravljanje zračnega prometa, standardizacija, obveščevalna dejavnost, raziskave in tehnologija ter vojaško zdravstvo. Pravilnik o planiranju na Ministrstvu za obrambo (2012) je smiselno prevzel določena planska področja Nata ter oblikoval nekatera lastna, ki so skladna z organiziranostjo in delovanjem obrambnega sistema. Pravilnik opredeljuje devet planskih področij, in sicer planiranje sil, obrambnih virov, organiziranosti, raziskav in razvoja, standardizacije, opremljanja in infrastrukture, logistične zagotovitve, obveščevalno-varnostne zagotovitve na strateški ravni in planiranje kriznega upravljanja na obrambnem področju.
} 
- transparentnosti in odgovornosti - transparentnost in odgovornost sta ključna pri razporejanju in upravljanju obrambnih virov na vseh ravneh planiranja. Če razporeditev obrambnih virov in njihovo upravljanje nista transparentna, obramba ne bo sposobna doseči javne podpore niti sodelovanja in podpore vlade. Civilno vključevanje in njen nadzor nad proračunskimi sredstvi lahko pripomore $\mathrm{k}$ temu, da je poraba razpoložljivih virov odgovorneje usmerjena v uresničevanje političnih ciljev (Le Rouf, 2002, str. 11);

- kontinuiranosti - planiranje je neprekinjen proces z drsnim sistemom ${ }^{12}$.

Temeljni namen obrambnega planiranja je nenehno zmanjševanje razkoraka med sposobnostjo (zahtevano in dejansko) in cilji obrambe. $Z$ boljšim predvidevanjem in napovedovanjem razvoja okolja, z variantnim oziroma kontingenčnim planiranjem, s fleksibilnimi plani in drugimi metodami se sicer lahko povečuje učinkovitost planiranja, vendar tveganja kljub temu ni mogoče povsem odpraviti. Zato nekateri planerji upravičeno mislijo, da je stopnja fleksibilnosti planov prvo načelo planiranja, glede na to, da ni smiselno oblikovati togih planov, saj prihodnosti ni mogoče povsem natančno predvidevati.

\subsection{Negotovost}

Tako kot je prihodnost vedno neznanka glede detajlov, ki se bodo zgodili, je tudi človekova varnost neznana in se ne more napovedati. Gray (2014a, str. 2-3) pravi, da je lahko bistven napredek pri ocenjevanju prihodnosti narejen s tem, da se postavljajo vprašanja, na katera je mogoče odgovoriti. Eno izmed pogostih nespametnih vprašanj je na primer »Kaj se bo zgodilo?«. Na to vprašanje ni mogoče dati odgovora, ki bi temeljil na znanju. Ko predmet obsega vojno in vojskovanje v njunih številnih različicah, prav tako prihaja do številnih »neumestnih « predlogov, ki naj bi pomagali pri kakovostnem napovedovanju. Obrambno planiranje si mora prizadevati ne le za obvladovanje izzivov, temveč mora biti pripravljeno tudi za spoprijemanje z nasprotujočimi mišljenji in vedenji, ki pa morajo vselej slediti ciljem. Problem obrambnega planiranja ni le v negotovosti prihodnosti, temveč tudi v pripravljenosti za srečevanje z neugodnimi, škodljivimi posledicami. Zato sprejetje odločitve o tem, katera predpostavka bi lahko bila odločilna glede prihodnosti, za obrambnega planerja nikakor ni lahka naloga.

Obrambno planiranje preprosto ne more temeljiti na objektivno zanesljivih znanstvenih dognanjih, ne glede na integriteto in spretnosti obrambnih analitikov. Gray (2014a, str. 1) ugotavlja, da to ne pomeni, da prihodnost prezremo, ampak da obrambno planiranje temelji na predpostavkah in domnevah. Dejstvo je, da tudi tako imenovane trde znanosti ${ }^{13}$ in mehke družbene ter humanistične vede posamezno ali skupaj niso sposobne napovedovati prihodnosti. Ne glede na omenjeno je izvajanje

\footnotetext{
${ }_{12}$ Drsnost pomeni, da se planski dokumenti občasno pregledujejo in dopolnjujejo z vidika vsebinske ustreznosti, predvsem glede na varnostno okolje, razpoložljive obrambne vire, razvojne prioritete in raven ambicij delovanja.

${ }_{13}$ Nasprotno od »trde moči« pomeni »mehka moč« sposobnost, da se želeni rezultati dosežejo brez uporabe groženj ali prisile, sčimer bi vplivali na spreminjanje vedenja ljudi.
} 
obrambnega planiranja nujno za prihodnost nacionalne varnosti, ki pa ne more biti podvržena diskrecijski pravici posameznika.

\subsection{Intelekt obrambnih planerjev}

Popolnega svetovanja ni, ker ni načina, s katerim bi bilo mogoče na primer natančno identificirati višino obrambnih izdatkov ali določiti obseg oboroženih sil v nekem prihodnjem obdobju. Politiki, ki zagovarjajo razvojne obrambne plane v vladi ali parlamentu, se morajo opreti na planske ocene, ki jih prevzamejo kot absolutna dejstva, torej, da je $\mathbf{x}$ tisto pravo ali potrebno število (finančnih sredstev, oboroženih sil, enot itn.). Porabo javnih finančnih sredstev za doseganje ciljev je treba upravičiti s tehtnimi obrazložitvami, zato so politiki prisiljeni zagovarjati, da so finančna sredstva natančno določena na podlagi strateškega izračuna potreb. Gray (2010, str. 160) pravi, da je spoprijemanje s prihodnostjo vselej negotovo in pomeni temeljno dilemo oziroma vprašanje pri oblikovanju obrambne politike in njenega programa vojaških zmogljivosti, ki temelji na podlagi predvidevanj, ocen. Pri tem se postavlja vprašanje, kako obrambni planerji upoštevajo resnost strateške realnosti pri obrambnem planiranju. Dejstvo je, da je enostavneje izvajati obrambno planiranje, če se prezirajo posebnosti potencialnih nasprotnikov in dopušča možnost, da se nasprotnik spoprijema s pomanjkanjem moči za iniciativo in nepričakovano reakcijo. Ali si v takšnih okoliščinah obrambni planerji sploh zastavijo ključno vprašanje, ki bi bilo usmerjeno v strateško preiskavo/poizvedovanje? Eden izmed izvornih problemov za postavljanje pravih vprašanj je tudi v pomanjkanju usposobljenosti in izobraževanja obrambnih planerjev. Gray (2010, str. 161) ugotavlja, da tudi akademski zbor ni opravil svojega dela v zvezi z ohranjanjem strateške misli. Ta neuspeh je bil in je še vedno rezultat zapostavljanja pomembnosti teorije strategije.

Bistvo politike je distribucija moči, medtem ko je bistvo strategije vplivanje na nasprotnikovo voljo. Danes razpravljavec o obrambnih zadevah, čeprav ima splošno vedenje o sodobnih izzivih in grožnjah varnosti, s katerimi se srečuje svet, premalo natančno pozna prihodnost, ki velja za najbolj nedostopen problem. Strateg mora pri svojem delu upoštevati in sprejemati ta dejstva in iskati načine, kako jih kompenzirati (Gray, 2010, str. 161-164).

Improvizacija, učinkovitost in planiranje v realnem času so pomembne spretnosti in lastnosti obrambnih planerjev, pomembno pa je tudi poznavanje logike in značilnosti strategije. Glavni namen izobraževanja o teoriji strategije je zagotoviti neke vrste intelektualno imunost na slabe koncepte. Šibka intelektualna zmogljivost se lahko pri vojakih kaže kot napačna presoja narave vojskovanja in posledično z neuspehom izpolnitve naloge glede na to, kako bi morala biti razumljena. Poleg poznavanja logike strategije, njene strukture in delovanja je treba obvladovati tudi retorične spretnosti. Dogaja se, da se vodijo obrambne razprave z napačno uporabo ali celo zlorabo konceptov - zato prihaja do zmešnjav ključnih terminov in do zmešnjave argumentov. Kadar politiki, uslužbenci, vojaki in mediji govorijo netočno o politiki, strategiji in operacijah, to nepopravljivo zavira njihovo lastno sposobnost pravilnega razumevanja problematike (Gray, 2010, str. 165-166). 
V strategiji je vse preprosto, toda ne tudi vse zelo lahko. Ko državna oblast sprejme strateške usmeritve oziroma odločitve, kaj mora in kaj more vojna doseči, se pot za to z lahkoto najde, vendar dosledno uresničevanje te poti in zastavljenega načrta zahteva veliko jasnost in gotovost duha (inteligenca, drznost, volja). V strategiji poteka vse dosti počasneje kot v taktiki, zato je veliko več prostora za pomisleke, ugovore in predstave. V strategiji je treba veliko stvari uganiti in domnevati, zato je tudi prepričanje manj močno. Posledica je, da večina generalov tam, kjer bi morali ukrepati, obtiči v napačnih pomislekih (po Clausewitz, 2004, str. 105-106).

Tako kot morajo dobri taktiki razumeti operativno delovanje, ki jim omogoča uspešno izvedbo naloge na taktični ravni, tako mora tudi operativni poveljnik imeti vedenje o strategiji za uspešno vodenje vojne in doseganje strateških in političnih ciljev. Nihče ne bi smel izvajati operativne ravni poveljevanja brez ustreznega znanja in razumevanja splošne teorije strategije (Gray, 2010, str. 168). Izobraževanje o teoriji strategije seveda ne more zaščititi države pred nesrečo, lahko pa koristno vpliva na politike pri sprejemanju občutljivih strateških odločitev. Strategija je lahko tudi precenjena. Toda zavedati se je treba, da se lahko z napačno izbiro strategije okrni jasna politična namera.

Razumevanje strukture in dinamike strategije bi moralo biti dovolj poznano med strokovnjaki za nacionalno varnost. Obrambni strokovnjaki bi tako morali biti sposobni razumeti spreminjanje vojaške zmogljivosti v vojaški učinek, vojaške učinke $\mathrm{v}$ strateške učinke in strateške učinke $\mathrm{v}$ politične učinke ali posledice. Veliko politikov na podlagi bogatih izkušenj uspešno sodeluje v politiki in vpliva na politično izbiro in izvršitev, tako kot so tudi vojaki izobraženi in usposobljeni za opravljanje vojaških nalog. Zelo malo civilnih ali vojaških oseb pa je izobraženih in usposobljenih, da bi bili sposobni spreminjanja strateškega učinka vojaških virov v želene politične posledice (Gray, 2010, str. 169). Zgodovina nas uči, da lahko že z »dovolj dobro« izdelano strategijo zagotovimo njeno zadovoljivo izvajanje, kar po drugi strani pomeni, da lahko tudi šibki strategi zmagujejo (če je nasprotnik slabši v strategiji ali če ima veliko materialno prednost, da ni treba sprejemati preudarnih odločitev). Gray (prav tam, str. 169) pravi, da strategija ni »panaceja«, vendar se lahko s poznavanjem teorije strategije (s čimer se lahko spreminja njena uporabna vrednost) povečajo možnosti za uspeh.

\subsection{Obrambne analize}

Glavni dejavniki, ki usmerjajo obrambno planiranje v praksi, so politika, strategija in (znanstvene) obrambne analize (Gray, 2014b, str. vii):

- politika na splošno odobrava obrambne napore in potrjuje oziroma upravičuje posamezne obrambne izbire,

- strategija usmerja obrambno planiranje in vojaška izvajanja na podlagi političnih ciljev,

- obrambno planiranje pretvarja strateške usmeritve $\mathrm{V}$ izvedljive rešitve $\mathrm{Z}$ dosegljivimi vojaškimi sredstvi (Gray, 2014b, str. 24). 
Zahtevne nacionalnovarnostne in obrambne analize se največkrat ne spoštujejo prav zaradi nezadostne odločnosti in prepričljivosti analiz kot celote, če te ne identificirajo dominantne grožnje. Islamski terorizem in geopolitično oddaljen konflikt, podnebne spremembe in drugi resni varnostni izzivi spodletijo, če ne privedejo do politične mobilizacije. Značilno za 21. stoletje je, da odziv na nevarnost ni neposredno povezan z vpletenostjo vojaške sile, kar bi z lahkoto prepričalo skeptične davkoplačevalce. Vrednost pravega strateškega sklepanja (dokazovanja, argumentiranja, mišljenja) in obravnavanje obrambe $\mathrm{v}$ kontekstu celovitega pristopa $\mathrm{k}$ varnosti sta ogrožena zaradi izpodbijanja presoj-ugibanj, ki ne temeljijo na metodologiji in kompetentnih merilih, prav tako pa ni nobenega zagotovila, da bi to lahko kako odpravili (Gray, 2010, str. 172).

Čeprav bo prihodnost odkrila, da je bilo v preteklosti veliko odločitev napačnih, lahko potencialno škodo minimiziramo zaradi takih napak. Dejstvo je, da je edini način presoja; vse mogoče in verjetne posledice prihodnjih strateških izbir izhajajo iz sedanjosti ali odsotnosti določenih vojaških zmogljivosti. Ambicija bi morala biti dobiti najboljšo (kar pomeni tudi dolgoročno dosegljivo) dovolj dobro odločitev za državo, ki se bo sposobna spoprijeti z nevarnostmi virov ogrožanja in tveganja, ne glede na to, ali jih je ali ni mogoče predvideti. Nacionalnovarnostne krize, kot pravi Gray (2010, str. 172-173), po navadi ne omogočajo zgodnjega opozarjanja, kar bi bilo zelo koristno za prilagoditev časovnice vojaških nabav.

Nobena država, ne glede na to, koliko virov ima na voljo njena oborožena sila, ni sposobna natančno identificirati svoje nacionalnovarnostne potrebe v srednjeročnem, kaj šele v dolgoročnem obdobju. Največ kar lahko doseže, je vojaška drža, prilagodljiva specifičnim okoliščinam, z zadostnim inventarjem zmogljivosti, ki pa se ne morejo predvideti podrobno (Gray, 2010, str. 173). Prilagodljivost in prožnost oboroženih sil je večinoma samo vprašanje materialnih sredstev. Zato je pomembno, da je strategija domiselna in pušča doktrini in obrambnemu planiranju prostor za prilagajanje spremembam.

Sklep Strateško razmišljanje je zahtevno, zato je poznavanje teorije zelo pomembno, saj zagotavlja metodološko podlago za strokovni miselni proces, ki pomaga strategom pri razvijanju strategije, prav tako pa deluje kot smernica za vse, ki so vključeni v vrednotenje in kritiko posamezne strategije. Poznamo tri vloge strategov, in sicer vodjo, praktika in teoretika, ki razvijajo vsak svoje spretnosti in kompetence. Vodja daje vizijo, pobudo, organizira, usmerja in spodbuja. Praktik prevede politične usmeritve v enotno strategijo, ki vodi k političnemu uspehu. Teoretik s študijami in razmišljanji razvija teoretične koncepte, svoja znanstvena dognanja vključuje v izobraževalne procese ter opravlja svetovalno vlogo (Yarger, 2006, str. 3). Strategi proučujejo okolje in razvoj strategij ter pri tem identificirajo cilje, koncepte in vire, potrebne za uresničitev ciljev, ki jih je postavila politika. Glede na to, da delujejo na različnih ravneh in $\mathrm{v}$ različnih vlogah, je prav tako pomembno, da razumejo celovitost strategij ter sodelujejo med sabo, z vodstvom, planerji in drugimi, ki sooblikujejo ter uresničujejo strategijo. Teorija pri tem spodbuja strateško 
razmišljanje s pojasnjevanjem strateške logike ter pomaga vodjem, planerjem in drugim pri vrednotenju in uresničevanju strategije.

Obrambno planiranje se prav tako srečuje s številnimi težavami, ki so posledica negotovosti in nejasnosti prihodnosti, ter predstavlja tudi velik izziv za obrambne planerje in politične odločevalce. Zaradi tesne prepletenosti s politiko je težko razumeti odnos med politiko in planiranjem, saj ne gre za enosmeren odnos nadrejenosti ali podrejenosti. Natančno oblikovana metodologija sicer pomeni koristno sredstvo za izvajanje obrambnega planiranja, vendar ne more predvideti vseh situacij niti odgovoriti na vsa vprašanja, ki se lahko pojavijo pri planiranju, zato se morajo planerji opreti tudi na lastno kreativnost. Uspeh v vojskovanju je, tako kot pri delu, povezan s sposobnostjo. Zato vključevanje inovativnosti in inventivnosti v strateško obrambno razmišljanje pomaga pri ostrenju lastnih pogledov na dogajanja $\mathrm{v}$ svetu in pri razvijanju miselnih procesov za boljše obvladovanje izzivov prihodnosti.

Zelo pogosto se dogaja, da pri obravnavi vprašanj o obrambi dominirajo kratkoročni pogledi, zasnovani na površni analizi izzivov in groženj varnosti oziroma stroškov za obrambo. V povezavi s tem se velikokrat upravičeno izpostavlja vprašanje »zakaj vlagati v obrambo, če ni nevarnosti? «. Izkustva kažejo, da se lahko strateške situacije spremenijo precej hitro, medtem ko so za vzpostavitev obrambnih zmogljivosti potrebni čas in sredstva. Da bi se izognili strateškim varnostnim tveganjem in njihovim posledicam, je treba planiranje razvoja obrambnega sistema proučevati $\mathrm{v}$ daljšem časovnem obdobju (Le Roux, 2002, str. 13). Obrambno planiranje nikakor ne bi smelo biti samo tehnični postopek, ampak predvsem pomemben politični proces, ki ga je treba obravnavati v političnem kontekstu. Če v obrambnem planiranju ni zagotovljena objektivnost, obstaja tveganje, da to postane samo politično orodje.

Proučevanje sprememb v okolju omogoča, da se pretehtajo nov prostor tekmovalnosti, politične konstelacije, razvoj tehnologije in drugi pospeševalci razvoja. To pa ni toliko stvar finančnih virov kot zamisli. Pri obrambi so to zamisli o prihodnjih vojaških ciljih, konceptih bojevanja in prihodnjih opcijah oboroženih sil. Razmišljanja obrambnih planerjev bi torej morala biti usmerjena predvsem $\mathrm{v}$ prihodnost, ki bi predstavljala eno izmed podlag pri odločanju razvoja in uporabe oboroženih sil. Njihovo poslanstvo bi moralo biti usmerjeno v pripravo dovolj dobrih planskih podlag za zagotavljanje nacionalne varnosti, zlasti z vojaškega vidika. Pri tem pa močno vodstvo in njena podpora predstavljata nujen pogoj za katero koli uspešno strateško planiranje.

Zavedati se je treba, da je varnost stanje duha, ki je v primerjavi s »trdo močjo« ni mogoče dobiti neposredno. Zato je razumljivo, da je javnost, ki je zaskrbljena za varnost, veliko bolj pripravljena nameniti potrebna sredstva za zagotavljanje te temeljne družbene vrednote. Očitno mora pri tem priti do časovnega zamika med političnim povezovanjem zaskrbljenosti in izdatkov za varnost, tako kot prihaja do časovnega zamika med obrambnimi izdatki in realizacijo strateško pomembnih vojaških zmogljivosti. Pred več kot pol stoletja je ameriški strateški mislec Bernard 
Brodie izjavil, da »ima obramba to, kar denar omogoča«. Ta misel danes še bolj kot v preteklosti predstavlja realnost zavedanja političnih odločevalcev o pomenu nacionalnega obrambnega sistema.

\section{Literatura}

1. Bartholomees, J., B. (ur.), 2010. Theory of War and Strategy (volume 1). The U.S. Army War College Guide to National Security Issues, Carlisle. Spletna stran www. StrategicStudiesInstitute.army.mil (13. 11. 2015).

2. Baylis J., Wirtz J., Cohen E., Gray C. (ur.), 2002. Strategy in the Contemporary World, An Introduction to Strategic Studies. Oxford University Press, New York.

3. Boorman A.,S., 2009. Fundamentals of Strategy: The Legacy of Henry Eccles. Naval War College Review, pomlad 2009, vol 62, no.2. Spletna stran www.usnwc.edu (13. 11. 2015).

4. Brodie, B., 1973. War and Politics. Cassell, London.

5. Carl von Clausewitz, 2004. O vojni. Studia Humanitatis, Ljubljana.

6. Cerami, R., J. in Holcomb, F., J., (ur.), 2001. U.S. Army War College Guide to Strategy. Strategic Studies Institue. Spletna stran www.StrategicStudiesInstitute.army.mil (13. 11. 2015).

7. Frühling, S. (2014). Defence Planning and Uncertainty: Preparing for the next AsiaPacific war. Routledge, Abingdon, UK and New York, USA.

8. Gray, C. (2010). Strategic Thoughts for Defence Planners. Revija Survival, volume 52, no. 3, str. 159-178. The International Institute for Strategic Studies, Washington.

9. Gray, C., 1999. Modern Strategy. New York, Oxford University Press.

10. Gray, C., 2006. Strategy and History, Essays on theory and practice. Routledge, Oxon.

11. Gray, C., 2014a. Defence Planning for National Security: Navigation Aids for the Mystery Tour. Strategic Studies Istitute and U.S. Army War College Press, Carlisle, spletna stran www.StrategicStudiesInstitute.army.mil (4. 11. 2015).

12. Gray, C., 2014b. Strategy \& Defence Planning; Meeting the Challenge of Uncertainty. Oxford University Press, United Kingdom.

13. Henrik Breitenbauch, H., (2015). Defence Planning. Academic Foresights No. 13, JanuarJunij 2015, spletna stran www.academic-foresights.com (4. 11. 2015).

14. Hodge, R. in Walpole, G. (1999) An Alternative Approach to Defence Capability Planning. Spletna stran http://www.chforum.org/library/aust_defence.shtml.

15. Javornik, M. (ur.), 1998. Veliki splošni leksikon v osmih knjigah, sedma knjiga S-Te. Državna založba Slovenije, Ljubljana.

16. Jervis, R., 1997. System Effects: Complexity in Political and Social Life. Princeton University Press, New York.

17. Joint Publication 1-02, (2010). Department of Defence Dictionary of Military and Associated Terms. Washington, DC: U.S. Joint Staff, 8. november 2010.

18. Kissinger, H., 1957. Nuclear Weapons and Foreign Policy. Harper\&Row, New York.

19. Koncept in metodologija načrtovanja obrambnega sistema (2000), Služba za načrtovanje obrambnega sistema, Ministrstvo za obrambo, Ljubljana.

20. Kotnik, I., 2012. Upravljanje instrumentov moči. Članek v Sodobni vojaški izzivi. Ministrstvo za obrambo, Generalštab Slovenske vojske, Ljubljana (str. 11-20).

21. Le Roux, L., 2002. The Military Budgeting Process: an Overview: Defence Planning, Programming and Budgeting. Accra, Ghana. Spletna stran http://www.sipri.org .

22. Luard, E. (Simoniti, I. in Grizold, A. (uvodni študiji)) (2001). Človek, država in vojna. Fakulteta za družbene vede (knjižna zbirka Mednarodni odnosi), Ljubljana. 
23. Lubi, D. (et al.), 1999. Raziskovalna naloga: Hierarhija dokumentov na področju nacionalne varnosti v Republiki Sloveniji (poročilo). Fakulteta za družbene vede, Obramboslovni raziskovalni center, Ljubljana.

24. Massie, L. J., 1987. Essentials of Management (fourth edition). Prentice-Hall, New Jersey.

25. Možina, S. (et al.), 2002. Management: nova znanja za uspeh. Didakta, Radovljica.

26. Pravilnik o planiranju, 2012. Ministrstvo za obrambo, št. 024-34/2011-21, z dne 13. 9. 2012, Ljubljana.

27. Premchand, A., 1994. Government, Budgeting and Expenditure Controls: Theory and Practice. International Monetary Fund, Washington.

28. Resolucija o strategiji nacionalne varnosti Republike Slovenije, 2010. Ministrstvo za obrambo. Ljubljana.

29. Rozman, R., Kovač, J., Koletnik, F., (1993). Management. Gospodarski vestnik, Ljubljana.

30. Stojković, D. in Dahl, R., B., (2007). Methodlogy for long term defence planning. Norwegian Defence Research Establishment (FFI), spletna stran www.ffi.no/no/ Rapporter/07-00600.pdf.

31. Yarger H. R., 2015. Towards A Theory of Strategy: Art Lykke and the Army War College Strategy Model. Spletna stran http://www.au.af.mil/au/awc/awcgate/army-usawc/stratpap. htm (2. 11. 2015).

32. Yarger, R. Harry, 2006. Strategic Theory for the 21st Century: The Little Book on Big Strategy. Washington: United States Government.

33. Žabkar, A., (2003). Marsova dediščina, temelji vojaških ved, 1. knjiga. Fakulteta za družbene vede, Ljubljana. 


\section{RAZVOJ OBRAMBNEGA SISTEMA ČRNE GORE}

\section{DEVELOPMENT OF THE DEFENCE SYSTEM OF MONTENEGRO}

Povzetek Pri iskanju najboljšega modela zagotavljanja lastne varnosti ima vsaka država svoje strateške razloge in specifike, ki pridejo do izraza pri sprejemanju končne odločitve o tem, po kateri poti želi država nadaljevati. Ko se je Črna gora ponovno osamosvojila in vzpostavila svoj državno-pravni status, je med drugim prevzela tudi novo funkcijo nacionalne obrambe. Po ustanovitvi leta 2006 je Ministrstvo za obrambo Črne gore svoje dejavnosti usmerilo v vzpostavljanje ustreznega pravnega okvira ter pripravo nujnih strateških in normativnih dokumentov. Hkrati s sprejemanjem normativnopravnih aktov je Ministrstvo za obrambo z neposrednim sodelovanjem v mehanizmih programa Partnerstva za mir in njihovem izvajanju razvijalo sistem obrambe v skladu z zastavljenimi cilji. Eno od najpomembnejših vprašanj v procesu evro-atlantske integracije je, kaj država z vstopom v Nato pridobi. Za Črno goro je ohranitev ozemeljske celovitosti in suverenosti ključnega pomena. V procesu vključevanja $\mathrm{v}$ evro-atlantske integracije sta reforma in gradnja vseh elementov sistema nacionalne varnosti Črne gore, še zlasti pa obrambnega sistema, veliko cenejša, njuna učinkovitost pa je veliko večja.

Ključne besede

Abstract In the search for the best model of providing for their own security, each country has its own strategic reasons and specifics that become visible when contemplating about the final decision on which way to go. After the restoration of independence and establishment of a new state-legal status of Montenegro, the new function of national defence was taken inter alia. After the official set up in late 2006, the Ministry of Defence was focused on the establishment of an appropriate legal framework and development of the necessary strategic and normative documents. In parallel with the adoption of normative-legal acts, the Ministry of Defence has through direct participation and implementation of the Partnership for Peace mechanisms developed 
the defence system in accordance with the set objectives. One of the most important questions in the process of Euro-Atlantic integration is what the state gains by joining NATO. For Montenegro, the preservation of the territorial integrity and sovereignty is of crucial importance. Through the process of Euro-Atlantic integration, reform and construction of all the elements of the national security of Montenegro and especially of the defence system is significantly cheaper, while at the same time their level of effectiveness is much higher.

\section{Key words Montenegro, Euro-Atlantic integration, defence system, the Armed Forces of Montenegro, NATO.}

Introduction After the bloody disintegration of Yugoslavia, in the early 1990s, Serbia and Montenegro established a common state called the Federal Republic of Yugoslavia, on the $27^{\text {th }}$ of April, 1992. Following numerous negotiations of both Serbian and Montenegrin political leaders in Belgrade and Podgorica in the course of 10 years, the President of the Republic of Serbia and the President of the Republic of Montenegro signed a joint document on the $4^{\text {th }}$ of February, 2003, which was called "Constitutional Charter of the State Union of Serbia and Montenegro". Therefore, the Federal Republic of Yugoslavia ceased to exist and dual community as the alliance of the republics of Serbia and Montenegro was established.

Since the State Union of Serbia and Montenegro did not manage to function in many segments, Montenegro decided to call a referendum on state independence on the $21^{\text {rd }}$ of May, 2006. The official results were published on the $23^{\text {rd }}$ of May. The results showed a narrow victory of Montenegrin independence, which was voted by $55.5 \%$ of voters. It is necessary to point out that the "narrowness" of the results existed because the European Union had imposed the limit of 55\% of the votes for independence. This resulted in the fact that de facto $1.22 \%$ of votes for independence counted as 1 vote against independence, which was not in line with democratic rules and was a precedent, but also a contribution to the contemporary European democratic practice (Tahirović, 2008, p. 18).

After the restoration of statehood, Montenegro opened a new page in its engagement in international relations. A year earlier, in June 2005, the Parliament of Montenegro declared future foreign policy priorities of the country adopting the Declaration on European Integration of Montenegro in which one part refers to security structures. Having in mind the obvious need of the state to intensify integration processes, after the restoration of independence on the $3^{\text {rd }}$ of June, 2006, the Parliament adopted the Declaration of Independence of the Republic of Montenegro. The Declaration highlighted the strategic determination of Montenegro to "join the European and Euro-Atlantic - NATO security structures and to continue to contribute to regional stability and security strengthening". 
After the restoration of independence and the establishment of a new state-legal status of Montenegro, the new function of national defence was taken over as well. The old concept of defence, based on the principles of the Cold War period, corresponded with the threats to state security that were out of date and not valid any more (Grizold, Čehulić, 2006, p. 21). At the same time, from the moment of loss of independence in 1918 until 2006, the function of defence was under the jurisdiction of the Government of joint states, which Montenegro was a part of. That had a considerable overall impact on the form and content of the future defence system of the newly created state.

Considering the existing situation, it was clear that after the restoration of statehood, it was necessary to establish a new defence system of Montenegro, which would be aligned with the new circumstances, environment, security challenges and threats, as well as new security and defence arrangements of the country (Djurović, Čehulić, Jaćimović, Tahirović, Milović, 2010, pp. 161 -218). Pursuant to the Decision of the President of Montenegro of $30^{\text {th }}$ of August, 2006 the conscription was abolished and the Armed Forces were transformed into professional forces.

At the NATO Summit in Riga on $29^{\text {th }}$ of November, 2006, Montenegro received an invitation to join NATO's Partnership for Peace programme. Very soon after that, on $14^{\text {th }}$ of December, 2006, the President of Montenegro signed the Framework Document of the Partnership for Peace at NATO headquarters in Brussels. By signing the Framework Document, Montenegro became member of the Partnership for Peace, which practically meant that Montenegro assumed all the obligations stipulated in this document (Tahirović, 2008, pp. 16-42).

Having in mind the obligations arising from the signing of the Framework Document of the Partnership for Peace, the preparation for drafting the Presentation Document of Montenegro on the participation in the Partnership for Peace programme started immediately. The document was handed over to NATO on $25^{\text {th }}$ of April 2007. The Presentation Document of Montenegro pointed out the principles on which the cooperation with the Alliance is based along with the objectives of the participation in the Partnership for Peace, priority areas of cooperation, PfP activities and financing participation in the Programme (Tahirović, 2010, p. 58).

For the purpose of an effective implementation and monitoring of these objectives, the Government of the Republic of Montenegro established the Inter-Agency Governmental Commission for the activities of Montenegro in the Partnership for Peace Programme, on the $28^{\text {th }}$ of December, 2006. Shortly afterwards, on $24^{\text {th }}$ of January, 2007, the decision was brought on the establishment of the Council for Partnership for Peace, chaired by the Prime Minister. The Ministry of Foreign Affairs and the Ministry of Defence established internal organizational structures for the activities regarding the Partnership for Peace and NATO. 
On $7^{\text {th }}$ of March, 2013, in order to improve and intensify activities within the PfP, the Council for Partnership for Peace was renamed the Council for NATO Membership headed by the Prime Minister. Simultaneously with the establishment of these structures, the National Coordinator for NATO was appointed in charge of coordinating all the intersectorial activities of Montenegro for membership in NATO.

This scientific work stems from the basic theme that the contemporary defence system of Montenegro is oriented towards building the capabilities and capacities in accordance with the strategic determination of NATO in the newest world rang and national interests of Montenegro. In the development of work, a combined model of methodology is applied by using scientific description, analysis of the content of strategic documents and laws as well as the analysis and interpretations of static indicators from the moment of starting the integration of Montenegro in NATO.

After its establishment in late 2006, the Ministry of Defence was focused on the development of an appropriate legal framework and necessary strategic and normative documents towards the implementation of the goals set in the process of Euro-Atlantic integration of the country and building up a completely new defence system, which would be compatible with the organizational structure of the North Atlantic Alliance.

\section{NORMATIVE - LEGAL BASES OF THE DEVELOPMENT OF THE DEFENCE SYSTEM OF MONTENEGRO}

Considering the fact that at the moment of accession of Montenegro to NATO's Programme Partnership for Peace - PfP in December 2006 the old Constitution of the Republic of Montenegro from 1992 was officially in use, and that it did not fit the new circumstances in which the country had found itself, there was a need to change it. Thus, in October 2007, the new Constitution of Montenegro was adopted in the Parliament of Montenegro. The new Constitution provided adequate conditions for the development of the necessary institutional framework at the national level for the development of the new defence system (Djurović, 2009, pp. 9 -39).

On the basis of the Constitution of Montenegro (Constitution of Montenegro, Art. 129), the Armed Forces defend the independence, sovereignty and national territory of Montenegro in accordance with the principles of international law on the use of force. The Armed Forces are under democratic and civilian control. Members of the Armed Forces may constitute a part of the international forces. Additionally, in order for the state to be able to function within the PfP programme, the Government of Montenegro within a very short timeframe adopted the National Security Strategy (June 2006), the Defence Strategy (July 2007) and the Law on Defence and Law on the Armed Forces. However, as one of the focal activities in 2008, there was a need for harmonization of strategic documents and laws with the new Constitution of Montenegro. 
At the end of 2008, Montenegrin Parliament adopted the new National Security Strategy and Defence Strategy, two of the most important strategic documents regarding security and defence system. The Defence Strategy of Montenegro is a document that provides answers to the most pressing issues in the area of functioning and development of the defence system.

As the accompanying form of these documents and the obvious need to adapt to integration processes, Montenegrin Parliament brought several amendments to the Law on Defence and the Law on the Armed Forces of Montenegro.

The Law on Defence regulates the organization and functioning of a unified defence system of Montenegro, the rights and duties of the holders of defence preparations and other matters of interest for the defence of Montenegro. With the amendments to the Law on Defence in 2012, the necessary preconditions were created, which, in addition to the National Security Agency of Montenegro, include intelligence, counter-intelligence, and security affairs, also organized and carried out within the Ministry of Defence and the Armed Forces of Montenegro.

In order to implement the new legal solutions, the Ministry of Defence established a new organizational unit - Department of Military Intelligence and Security Affairs. Following the 2012 amendments to the Law on Defence and recognizing that standardization is a key lever of internal military organization, the Ministry of Defence in 2013 created the conditions for the adoption of the Rulebook on Standardization in the Field of Defence and thus provided a legal basis for standardization in the field of defence. With the adoption of standards of defence Montenegro formally fulfilled yet another condition required for reaching interoperability with partners and becoming a NATO member (Tahirović, Petrič, 2015, pp. 117 - 118).

The Law on the Armed Forces regulates the organization of the Armed Forces of Montenegro, the service in the Armed Forces, rights, obligations and the status of personnel in the Armed Forces during the service and other issues of importance for the Armed Forces.

The Armed Forces consists of branches, arms and services. It is composed of Army, Air Force and the Navy. Branches and services are determined by the Government of Montenegro. The Armed Forces of Montenegro are composed of full-time personnel and members of the reserve component. Full-time personnel of the Armed Forces include military personnel and civilians. The Army Reserve forces are composed of the active and inactive reserves. The size, composition and manner of recruiting the active reserve of the Armed Forces are regulated by the Government. Military personnel include professional military personnel, cadets, soldiers in training and reserve personnel while in the Armed Forces. Persons serving in the Armed Forces are professional military personnel and civilians. 
One of the basic defence documents, besides the Strategy of National Security and the Defence Strategy of Montenegro is the Defence Plan of Montenegro, which consists of the documents which include a plan of preparation for the achievement of the defence objectives within the defence system of Montenegro. The Government of Montenegro adopted the Defence Plan of Montenegro, at its session on $29^{\text {th }}$ of December, 2008.

For the purpose of timely and smooth exchange of information with NATO, the Law on Data Confidentiality was adopted in February 2008. Immediately afterwards, the need occurred for a normative-legal regulation of deployments of Montenegrin representatives to international missions and operations. Consequently, the Law on Deployment of the Armed Forces of Montenegro Units to the International Forces and Participation of Members of Civil Defence, Police and Public Administration Employees in the International Missions and Other Activities Abroad was adopted.

The Parliament of Montenegro makes decisions on the use of Armed Forces units in the international forces, at the proposal of the Security and Defence Council. The Council decides on the participation of Armed Forces members in exercises or trainings abroad in accordance with the assumed international obligations. Army units shall be manned on voluntary basis. Units of the Armed Forces and members of the civil defence and employees who are well-prepared, trained and equipped are sent to the international forces, peacekeeping missions and other activities abroad.

Preparation, training and equipping of the units of the Armed Forces, civil protection members and other employees, as well as monitoring and coordination of their engagement in international forces and peacekeeping missions and other activities abroad, are carried out by state administration bodies, the ones who brought decision about their deployment.

The Law on Parliamentary Oversight of Security and Defence Sector regulates the parliamentary control over the work of the organs and institutions in the field of security and defence, the manner of performing parliamentary oversight functions of bodies and institutions which are subject to parliamentary oversight and other issues of importance for the exercise of parliamentary control.

As provided in the Presentation Document in section 3, paragraph 7, and in order to continue a planned and organized defence system reform, the Ministry of Defence began to draft the Strategic Defence Review (SDR) of Montenegro in early 2008. It was completed in July 2010 (Tahirović, 2008, p. 9 -10). Given the fact that the process of integration should be intensified and that the former did not provide the expected results, primarily due to omissions in the content of the document, we started with a new one which was adopted in July 2013. Key changes in the new Strategic Defence Review include redefinition of defensive missions, reorganization of the MoD, transition from brigade to battalion organization of the Armed Forces and definition of a new organizational structure. 
On the basis of the Strategic Defence Review and its implementation at the end of 2014, a new Formation of the Armed Forces of Montenegro was made. At this stage, the new formation of the Armed Forces predicts downsizing of the AF at first to 1,950 members and then to 1,800 members by the end of 2018 (the current size of the Armed Forces is 2,095 members). The reorganization is looking to achieve substantial changes in the organizational structure of the Armed Forces of Montenegro (MNE AF) and the functional relationships of its organizational units. The move from brigade to battalion level of organization created more effective operational capabilities of the units.

In accordance with the Law on Civil Servants and State Employees of Montenegro, which entered into force in January 2013, and in order to reduce the risk of corruption, the Ministry of Defence started to work on the MoD Integrity Plan, which was adopted at the beginning of October 2014. On the basis of the analysis of the situation in the MoD, the Integrity Plan includes measures which the MoD and the MNE AF will implement by the end of 2016. There are about 63 measures requiring amendments to laws and bylaws, trainings for the MoD staff and members of MNE $\mathrm{AF}$, the introduction of new procedures, greater transparency of the activities of the $\mathrm{MoD}$ and MNE AF, better cooperation with the industry, civil society and the media.

The main strategic document which is used for planning and designing the development of the AF and the defence of Montenegro is Defence Long-Term Development Plan, which was adopted by the Government of Montenegro in February 2016. Defence Long-Term Development Plan is defence planning document which sets long-term goals and priorities of development, the future abilities of the MNE AF, content and pace of development, financing and other issues of importance for the functioning and development of the defence system.

This document is used for planning the development of the defence system in the period from 2016 to 2025 . Once reaching the projected capabilities, units of the MNE AF will be able cooperate with allies and partners in effectively carrying out the assigned tasks at the national level, assuming the obligations from full-fledged NATO and EU memberships and contributing to international peace through participation in multinational operations under the auspices of NATO, the UN and the EU. This document is a starting point for the development of all development plans and plans for the implementation of Defence Long-Term Development Plan within the Ministry of Defence and the Armed Forces of Montenegro, including the proposals of defence spending in the Budget of Montenegro.

\section{EURO-ATLANTIC INTEGRATION AND THE DEVELOPMENT OF THE DEFENCE SYSTEM AND THE ARMED FORCES OF MONTENEGRO}

In parallel with the adoption of normative-legal acts and through direct participation and implementation mechanisms of the Partnership for Peace, the Ministry of Defence developed defence system in accordance with the set objectives. From the moment 
of accession to the Partnership for Peace, Montenegro has been implementing four mechanisms of cooperation with NATO: Individual Partnership and Cooperation Programme- IPCP, Planning and Review Process - PARP, Individual Partnership Action Plan - IPAP and the Intensified Dialogue - ID. The largest volume of commitments through the Partnership for Peace refers right to the Ministry of Defence and the AF of Montenegro (Tahirović, 2008, pp. 34 - 38).

\subsection{The mechanisms of the Partnership for Peace}

Individual Partnership and Cooperation Programme - IPCP was until the $1^{\text {st }}$ of January, 2012 called Individual Partnership Programme (IPP). The first IPP of Montenegro was created in October 2007 and approved by NATO in January 2008. In 2008, it was planned that Montenegro participates in 69 activities in the following areas: language study, medical support, military education and training and military doctrine. After consultation with NATO, the activities of the IPP in 2008 have been revised, so that the number of total activity was reduced to 48 in accordance with real possibilities and capacities of Montenegro (Mijović, 2008, pp. 9 - 10). In 2014, Montenegro implemented the seventh cycle of IPCP, which included 94 activities. The planned activities were carried out with a high degree of realization.

Through the mechanism of PfP Planning and Review Process - PARP Montenegro has set the requirements in the development of its own capabilities, in the form of Partnership Goals - PGs, which we need to achieve (Tahirović, 2008, pp. 9 - 10). Partner countries decide about the PARP content either on the basis of the Presentation document, or on the basis of a subsequently adopted political decision. PARP is actually a standardization form at the operational, financial and administrative levels. It will continue until Montenegro becomes a full-fledged NATO member. Partnership Goals (PGs) are tools that are mostly used for the development of a wide range of capabilities, such as military capacity, emergency response, fight against terrorism, reaching of safety standards, secure exchange of classified information with NATO, border security etc. Most of partnership goals mean reaching the required standards of equipping (compatibility of equipment) and the adoption of NATO concepts, doctrine and procedures. They actually define the level of interoperability of the AF and other security structures of the system which should be achieved in different areas.

Interoperability, as the ultimate goal, represents the possibility of common (synergetic) effects of NATO and Montenegro during the execution of assigned missions and tasks. It is achieved by applying the existing standards in the given field. Besides the MoD and the Armed Forces of Montenegro, partnership objectives are also carried out by the Ministry of Interior (Police Directorate and Directorate for Emergency Situations), Directorate for the Protection of Classified Information and the Ministry of Foreign Affairs and European Integration.

In September 2007, Montenegro submitted the answers to the first PARP Questionnaire, which was presented in Brussels on the $31^{\text {st }}$ of March, 2008. On this occasion, the first Package with 32 Partnership Goals was adopted. The priorities in 
the Partnership Goals were the language studies and preparation of the units for the participation in international peacekeeping missions (Mijović, 2008, pp. 9 - 10). In June 2008, Montenegro received another PARP questionnaire, for which the answers were given and handed over to NATO on $29^{\text {th }}$ of September, 2008. At the joint meeting of representatives of 28 NATO member states and the delegation of Montenegro on the $1^{\text {st }}$ of March, 2010 in Brussels, the second package of Partnership Goals for Montenegro was adopted. It contained 51 Partnership Goals (In the previous period we implemented 5 Partnership Goals; 27 PGs were left from the first package, and the 24 new were added).

The third package had 49 Partnership Goals. During the implementation of the Partnership Goals from this package, the progress in the implementation of the following areas was particularly highlighted: successful assessment of the first declared company of the MNE AF-level SEL 2; establishment of the Naval Operational Centre for Sea Surveillance; an infantry company of the MNE AF, declared by the Operational Capabilities Concept - OCC (OCC Operational Capabilities Concept) fully equipped with all the CBRN agents since 2013; improvement of the Information and Communication System of the MoD and MNE AF; emergency management; significantly improved English skills of members of the AF of Montenegro; established software for codification BULCOD and NATO MailBox where 48 subject entries were codified; preparation of the rulebook on standardization in the field of defence and the establishment of the Commission for Standardization.

The Operational Capabilities Concept - OCC is a PfP mechanism that enables the Armed Forces of Montenegro to assess the quality of the operational capabilities of declared units. The aim of this programme is to improve the levels of interoperability and operational capabilities of declared units in order to be prepared for the participation in NATO-led operations. The OCC is basically a four-year process that consists of four components: training, education, exercises and evaluation. When the necessary training including the adoption of NATO operational standards is completed, it is followed by the evaluation of declared forces which had passed the training. The OCC incorporates two levels of assessment: the first level-SEL1 selfassessment and NATO evaluation NEL-1, and the second level-SEL-2 and NEL-2. The evaluation concerns the decision-making process, issuing of orders, use of units, reporting and equipping of the unit. The first infantry company of the Armed Forces of Montenegro, which is declared by the Operational Capabilities Concept - OCC, has fully met the very demanding NATO standards. It is the final assessment of NATO evaluation team after the end of the exercise "Decisive Step 04", which was held in Pljevlja on $18^{\text {th }}$ of September 2014. The unit at the level of NEL-2 was graded with the highest rate, i.e. "combat ready". Thus, a four-year process, in which all members of this unit participated, came to an end. The given grade confirmed the quality of this unit, as well as the quality of equipping, training and level of interoperability of the Armed Forces of Montenegro, which in this area has achieved the required level of readiness for equal participation in international missions and operations 
led by NATO. It is also important to note that 16 members of the Armed Forces of Montenegro have become certified instructors (trained for the assessment according to NATO standards) for Level 1 and 10 instructors for Level 2. The training of another infantry company in accordance with the OCC is currently underway and its assessment at SEL-1 level was carried out at the end of 2015. The equipping of the declared forces at the Operational Capabilities Concept - OCC of the Armed Forces of Montenegro represents the process of reaching capabilities according to NATO standards in order to participate in NATO-led international operations.

\subsection{Human resources at the Ministry of Defence and the Armed Forces of Montenegro}

Personnel needs or human resources is one of the most important areas of the society, which the state must ensure in order to proceed with the process of European integration smoothly. At the moment of regaining its independence, Montenegro inherited more than 6,000 soldiers from the common state of Serbia and Montenegro. At that time, the Armed Forces of Montenegro was formed from the Podgorica Corps, Navy Corps, parts of Aviation Corps, the Air Defence Corps and parts of the units subordinated to the General Staff of the Serbia and Montenegro Army, which were at the time located in the territory of Montenegro. Immediately after the referendum, on $30^{\text {th }}$ of August, 2006, conscription was abolished in line with the Decision of the President of Montenegro and since then only professional military personnel on a voluntary basis created the composition of the Armed Forces of Montenegro. At the end of 2015, the Armed Forces of Montenegro together with the Ministry of Defence personnel includes 2,057 members whose structure is given in the table below.

Defence system of Montenegro

\begin{tabular}{|l|c|c|}
\hline Category & Total of employees & Female members \\
\hline Officers & 310 & 17 \\
\hline NCOs & 817 & 38 \\
\hline Contract soldiers & 541 & 104 \\
\hline Civilians & 240 & 91 \\
\hline Civil servants & 149 & 258 \\
\hline Total & 2057 & \multicolumn{2}{|c|}{} \\
\hline
\end{tabular}

Ministry of Defence

\begin{tabular}{|l|c|c|}
\hline Category & Total of employees & Female members \\
\hline Officers & 55 & - \\
\hline NCOs & 7 & 91 \\
\hline Civil servants & 149 & 91 \\
\hline Total & 209 & 9 \\
\hline
\end{tabular}


Armed Forces of Montenegro

\begin{tabular}{|l|c|c|}
\hline Category & Total of employees & Female members \\
\hline Officers & 255 & 8 \\
\hline NCOs & 810 & 17 \\
\hline Contract soldier & 541 & 38 \\
\hline Civilians & 240 & 104 \\
\hline Total & 1843 & 167 \\
\hline
\end{tabular}

It is worth noting that during the separation of Serbia and Montenegro, professional military personnel was on the basis of the Law on the Armed Forces of Yugoslavia given the possibility to choose the Member State in which they would continue their professional service in the future. Since the referendum on Montenegro's independence, which was held on the $21^{\text {st }}$ of May, 2006 by the beginning of 2007 , 589 professional military personnel moved from Montenegro to Serbia 321 of which were officers, mainly younger people up to the rank of Major, and 268 noncommissioned officers. Also, 15 military personnel, 7 of which were officers and 8 non-commissioned officers moved from Serbia to Montenegro.

This was one of the key problems at the beginning of the integration process. There was a need to find the answer to the question how to compensate such a huge number of young seniors, primarily officers, who should be the key actuators of the integration process. At the same time, a significant number of non-commissioned officers and officers who remained in Montenegro in the moment of forming the Armed Forces of Montenegro opposed the integration of Montenegro into NATO, due to the NATO's 1999 bombing of the FRY or they were not adequately informed about the significance of the Euro-Atlantic integration for Montenegro.

In such a situation, support was sought from our partners, who had adequate possibilities to support Montenegro on these issues. Thus, in order to solve these problems, Montenegro started with various projects with partner countries, where the most important ones included the following: a) the Norwegian project Defence and Security Sector Reforms - DSSR; b) American International Military Education and Training program - IMET; c) The contract with the US corporation Military Professional Resources Incorporation - MPRI, on the training of Montenegrin contingent for peacekeeping operations, and d) Agreement with the University of Donja Gorica in Podgorica on the education of the Ministry of Defence personnel.

Having in mind the strength of the Armed Forces of Montenegro and Montenegrin strategic commitment to become a NATO member, it was more rational to organize the education and training of personnel in the existing academies and training centres abroad through the use of the Partnership for Peace mechanisms, rather than to build our own educational institutions. In order to implement this, few individual agreements were signed within the framework of bilateral cooperation between the Ministry of Defence and the ministries of defence of partner countries and NATO 
member states, on the basis of which the schooling and other forms of staff training is carried out.

After regaining independence, the MoD sent cadets to military academies in Greece for the first time in 2007. After that, they were appointed to military academies in the Republic of Serbia, the USA and so on. By 2014, 52 cadets graduated from military academies abroad, four of whom were female cadets.

So far, the cadets of the MNE AF have been educated in:

- Serbia: Military Academy and the Military Medical Academy; the following branches: infantry, aviation, CBRN, financial services, communication, militarytechnical service (29);

- Republic of Greece: Army Academy, the infantry and traffic, Air Force Academy, aviation engineers and pilots and Naval Academy for maritime engineers (9);

- Federal Republic of Germany: Army Academy and Naval Academy in the communications, military police, engineers and logistics (6);

- Macedonia: Army Academy "General Mihailo Apostolski”, the infantry, CBRN, PSC, Artillery and Engineers (6);

- US: Naval Academy in Annapolis (2);

- The Republic of Italy: Naval Military Academy in Livorno;

- Croatia: Military Academy "Petar Zrinski”.

By the end of 2015, 28 cadets have been educated in foreign military academies for the needs of the Armed Forces of Montenegro nine of whom were female cadets:

- 1 cadet at the Medical Faculty of the Military Medical Academy in the Republic of Serbia;

- 10 cadets in the Academy of the Army, Air Force Academy and Navy Academy in the Republic of Greece;

- 12 cadets in the Army Academy in the Republic of Macedonia;

- 10 cadets / activists at the Army Academy, Air Force Academy and Navy Academy in the Republic of Greece;

- 12 cadets at the Army Academy in the Republic of Macedonia;

- 2 cadets at the Naval Academy in the United States;

- 2 cadets at the Naval Academy in the Republic of Italy and

- 1 cadet at the Military Academy "Petar Zrinski" in Croatia.

Normally, the Ministry of Defence does not bear the costs of tuition for the cadets; however, it provides monthly cash payments in accordance with the Rulebook on allowances and other earnings of cadets. The Ministry of Defence also covers travelling expenses for their arrival during winter and summer holidays, and religious holidays, as well as the cost of residence permits, visa costs and other expenses incurred during the training.

Besides education programmes at military academies, members of MNE AF have since 2007 been taking part in the General Staff and Command training and 
specialization for officers and NCO corps, which has so far been attended by 70 members of the MNE AF, in Serbia - 6; Croatia - 22; USA - 24; Germany - 4; Italy - 4, EE - 2; Greece and Macedonia -7. At the same time, it is important to note that two members of the MNE AF have the highest level of military education in the United States at the US Army War College and one at the US Navy War College. In 2015, another candidate from the MNE AF was sent to the US Army War College in the United States.

In addition to education and training, a significant number of members of MNE $\mathrm{AF}$ and officials from the Ministry of Defence have so far participated in various language courses (191) and other courses (853), trainings (590), exercises (365), seminars (160) and workshops (111) abroad through a variety of PfP mechanisms or bilateral and multilateral forms of cooperation, where they had the opportunity to gain new and improve the existing knowledge in order to achieve the necessary degree of interoperability with NATO members. In different training programmes since 2006 to date, 96 participants from Montenegro (80\% from the Ministry of Defence and MNE AF) have attended training at the European Centre for Security Studies George C. Marshall Center in Garmisch-Partenkirchen, Germany.

With the aim to create continuous process of situation monitoring and management of human resources in the Ministry of Defence, the Strategy for the Development of Human Resource Management (HRM) was adopted in March 2014 in the Ministry of Defence of Montenegro, and the Action Plan for the implementation of the Strategy in the period from 2014 to 2016 (Tahirović, Petrič, 2015, p. 145). When it comes to the Montenegrin higher education institutions, except the private University Donja Gorica, which develops a plan and programme of security studies as part of the humanistic studies, the University of the Mediterranean, which has a Department of Safety in Bar and Higher Specialised School of Internal Affairs at the Police Academy in Danilovgrad, other educational institutions with the safety programmes do not exist in Montenegro. This should, of course, be changed in the future, because regardless of the fact that it is cheaper and more cost-effective to use NATO and partner resources for education, training and scientific activities, it is still necessary to some extent to create a recognizable profile of Montenegrin personnel, which requires the development of local educational institutions in the field of security. ${ }^{1}$

In the past, the learning of foreign languages was one of the most essential requirements in the implementation of Partnership Goals and training of human resources. Special emphasis was put on the English language, which was of most use to members of the Armed Forces of Montenegro and the officials of the Ministry of Defence. In the period from 2007 to 2014, 177 members of MNE AF, 5 civilian personnel serving in the MNE AF and 9 officials from the Ministry of Defence completed foreign language courses at different levels of knowledge. This is very

Mehmedin Tahirović, Article: Učešće Crne Gore u PzM i MAP-u, Zbornik škole euroatlantizma I-Sesija,

Univerzitet Donja Gorica, Podgorica, 2010. , pp. 139 - 174. 
important in order to achieve the necessary level of interoperability with NATO, and to be able to smoothly implement joint activities in the country and abroad.

\subsection{NATO codification and standardization system in the Ministry of Defence and the Montenegro Armed Forces}

NATO codification system was created because of the need of allies to be interoperable with each other, or in the material sphere and the sphere of logistics, to be able to speak out with one identical language understandable to everybody. The basic idea of codification is very simple; however, it is hidden behind a complex organization led by the AC/135 Committee, through a complex software system in the NATO Support Agency - NSPA, where a system of communication with different commercial software products from 55 countries worldwide has been implemented. Codification of Montenegrin products provides the ability to use the advantages of much larger markets.

Commercial and Government Entities - CAGE, are assigned to the producers and vendors in order to uniquely identify the manufacturer. National CAGE is awarded by the National Codification Bureau of Montenegro or the Ministry of Defence. The national codification numbers representing domestic production have the numeral 77. All manufacturers and other economic entities, as well as the authorities and other institutions are represented by a special code (NCAGE - NATO Commercial and Government Entity Code). Labels of the domestic manufacturers, businesses, institutions and state bodies of Montenegro begin with letter A, and end with letter $\mathrm{W}$, in the format $\mathrm{A} * * * \mathrm{~W}$. In electronic data exchange, the National Codification Bureau of Montenegro is labelled with VH. The first codification of Montenegro was done in December 2011 with the help of instructors from the Ministry of Defence of Bulgaria, during the setup of the operational software BULCOD and the first training for its usage.

So far, 76 products have been codified in Montenegro. These include the products of Tara, 13. Jul - Plantaže, Franca-Mesopromet, Suza Water Group, Poliex, Martex, agricultural producer Goran Mijušković, Fabrika vode Lipovo, AD Bjelasica Rada. In addition to these companies, NATO Commercial and Government Entity NCAGE codes were awarded to the following companies: Jadransko brodogradilište, Jugobicikl-Promet trgovinsko, Jadroagent Bar, Studio mouse, MB Electronic, Nikšički mlin, Montenegro Defence Industry, Port of Bar, Port of Kotor, Travel agency, Hipotekarna bank, Interprodukt, Matic MT. By obtaining this code, all the companies have entered into the NATO master catalogue, database of companies and organizations of 28 NATO countries and 38 non-NATO members, which offer their products and services to NATO member states.

Pursuant to the Rulebook on Defence Standardization, which the Ministry of Defence issued in May 2013, the formal legal basis for standardization in the field of defence was provided. On the basis of these Regulations, the Commission for standardization has been formed as an advisory body to the Minister of Defence in the field of 
standardization. The Commission has subsequently developed a Standardization Plan, on the basis of which they established working groups to prepare defence standards according to the procedures given in the Rulebook on Defence Standardization.

In May 2014, in the process of the implementation of standardization in the Ministry of Defence, which represents the key lever of internal military organizations, Defence Minister signed the decision on the adoption of the first standards of defence in Montenegro, - SO STANAG 6001 language proficiency levels, which is used to define and explain language levels. The standard was adopted by taking over the NATO standard STANAG 6001 "Language proficiency levels (Edition 4)." This standard will be applied by the Ministry of Defence and the Armed Forces of Montenegro and other state authorities which cooperate with NATO. The Ministry of Defence and the AF of Montenegro have already planned and organized English language training at home and abroad, harmonized with the criteria provided in STANAG 6001. The testing of MNE AF and MoD members in accordance with this standard is carried out by certified STANAG 6001 testing teams.

According to the 2014 Standardization Plan, the adoption of 90 standards has been planned that are necessary for the attainment of Partnership Goals, the implementation of the Strategic Defence Review, the modernization of equipment and training of the Ministry of Defence and the Armed Forces of Montenegro. By adopting the standard of defence, the Ministry of Defence formally fulfils yet another condition required to achieve interoperability with NATO members.

\subsection{Joint military exercises}

In the process of the security system reform, and especially defence system, Montenegro seeks to reach the required level of interoperability of forces and resources with the members of the Alliance as soon as possible. This is done by training MNE AF members, which contributes to the increased level of professional skills and continuous implementation of operational, financial and administrative standardization of the forces. One of the most effective ways of reaching and testing the level of interoperability is the participation in joint exercises with NATO.

In order to demonstrate and improve the operational capabilities of units, the implementation of adopted NATO procedures and standards, as well as the capabilities of the command personnel in military decision making process, members of the Armed Forces of Montenegro participated in 23 international exercises at training ranges in Germany, Sweden, the Czech Republic, the United States, Turkey, Slovenia, Italy, Croatia, Greece, as well as in Montenegro in 2014. These are international exercises of NATO and Partnership for Peace nations, in which the Armed Forces of Montenegro took part with staff officers, non-commissioned officers and units at squad level. A total of two hundred members of the Armed Forces of Montenegro participated in the exercises, 121 of which participated in the exercises conducted abroad. In addition to harmonizing procedures and standards in operation and equipping, the exercise develops trust and cooperation, which is of special importance. 
In addition, participation in the exercises was also aimed at the application of NATO standards and procedures in providing logistical support to NATO-led operations. Additionally, it required the development of national capacities for response in the event of natural disasters and incidents caused by human factor and responding of the military medical personnel in such situations and providing support to civil institutions, as well as improving the interoperability and training procedures in the planning and execution of international maritime operations. The main goal was to strengthen security at sea, which is achieved by participation in a series of international maritime exercises. The decision on the participation of members of the MNE AF in military exercises in the country and abroad is made by the Council for Security and Defence.

\subsection{Protection of the airspace of Montenegro}

The protection of airspace is one of the most important and complex challenges faced by almost all countries in the region. Even for some much larger countries than Montenegro, independent addressing of this issue is an extremely expensive and irrational solution. Therefore, Montenegro has committed itself to resolve this important issue through a process of cooperation at regional level and through the process of integration in the collective security system.

Considering the location and proportions of airspace, possible threats to the airspace, as well as the viability and status of the existing aircraft, it has been decided that the composition of the Armed Forces of Montenegro will not include combat aircraft, but a helicopter unit. Sovereignty over the airspace will be provided through the construction of a sustainable system of control, monitoring and protection of airspace together with the countries in the region, partners and allies, which is fully in line with the commitment of Montenegro to join European and Euro-Atlantic institutions. In addressing specific issues in the field of supervision and control of the airspace of Montenegro, two important projects have been initiated.

The first project is the Balkan Regional Approach to Air Defence-BRAAD. In addition to Montenegro, this project involves Bosnia and Herzegovina and Macedonia. The defence ministers of those countries have agreed that NATO Agency for Communications and Information Technology - NCIA makes a joint study on control of the airspace, which will include national, regional and NATO approach in the field of supervision and control of airspace. The Republic of Croatia has the role of the leading nation and represents the interests of NATO countries involved in BRAAD. The aim of the BRAAD initiative is to coordinate activities and cooperate in the development and modernization capabilities to protect the airspace of the countries in the Balkans, to increase interoperability between the states in BRAAD initiative with NATO and provide a significant reduction in the cost of these states through joint procurement of the necessary funds. Furthermore, in this way, duplication of the capacities for surveillance and protection of the air space of countries involved in BRAAD will be avoided and the costs will be additionally reduced, which is the basis of "smart defence" projects. The generation of the complete study of the 
three countries will cost $€ 199,999.98$, for which the Ministry of Defence paid NCIA $€ 66,666.66$. The same amounts will be paid by Bosnia and Herzegovina and the Republic of Macedonia. The "BRAAD" study will provide the necessary technical inputs and financial circumstances to improve the control of air space of Montenegro and the exchange of information on control of the airspace. Then it will be possible to accurately assess all the costs of the supervision and protection of the air space of Montenegro.

The second project, "ASDE" - NATO (Air Situation Data Exchange), aims to exchange data with NATO on the situation in the airspace. This is the initial step for the country's accession to other NATO programmes which serve and allow for improved control of airspace in the country. The Ministry of Defence of Montenegro submitted a request to the Command of NATO to access "ASDE" programme. NATO has approved the inclusion of Montenegro in this programme and its implementation is underway. By 2014, 102,867.38 € were spent for the purchase of the information and communications equipment for the implementation of the "ASDE" project.

In addition, the Ministry of Defence has started with the reconstruction of the Air Operational Center, at the military airport Golubovci, and has so far spent around $100,000.00 €$ for it. The aim is to establish a modern Centre, which will have the capabilities of continuous monitoring of the situation in the airspace through the collection of data from its own sources and their exchange with Montenegrin civil aviation entities, NATO and neighbours. This further means the purchase of new modern radar that will enable the integration of radar image at national and regional levels and data exchange with NATO. Montenegrin Government has accepted the recommendations that were the result of consultations with NATO experts and opted for the Vrsuta location, above the city of Bar, as an optimal solution for setting up military radar for airspace surveillance in Montenegro.

Currently, activities within bilateral cooperation with the US are underway regarding the provision of FMF funds to equip the Air Force Operations Centre. The Centre will be equipped according to the same model as the Navy Operations Centre and there is a possibility of acquiring one adequate radar. In the future, the medium term priorities in providing conditions for the protection of the air space of Montenegro are the following: equipping of the Air Operations Centre and its connection with NATO, purchase of multi-functional multi-purpose helicopters and modern radars, air defence modernization, as well as resolution of the issue of "air policing" through NATO's collective security system.

\subsection{Protection of the sea}

Taking into account the size of the sea over which Montenegro has jurisdiction as well as the material constraints, the Navy of Montenegro has decided to develop a combined system of control and protection of the sea. This system consists of highquality surveillance system that allows it to possess a realistic picture of the sea in real time (RMP Recognize Maritime Picture) and a sufficient number of ships and 
other vessels to perform tasks at sea. In this way, sovereignty and territorial integrity are not compromised, but lower costs in the defence system are achieved.

The first step in establishing a combined model was the opening of the National Naval Operations Center - NMOC in 2013, which collects data with modern observation sensors and which processes and exchanges data at sea at the national level, with neighbouring countries and beyond.

The second step is the successful completion of the overhaul of the main propulsion system of the Navy patrol boat class "Kotor" P-33 in 2014. After several years, the ship is now technically fit to carry out tasks at sea. Only in the second half of 2014 there were seven such tasks, with a total of 614NM. In this way, the Navy has significantly improved the implementation of the tasks and its maritime presence. The Navy is developing this task, or better the improvement of its own capabilities and competences of ship crews, in cooperation with the countries in the region in the context of regional security initiatives such as ADRION. In this way, in addition to the development of regional capacities, our interoperability and progress in the integration processes is also improved.

Following the guidelines from the Strategic Defence Review, based on which medium- and long-term plans for the development of the Navy of Montenegro are made, it is planned to continue with the development of NMOC in order to achieve data exchange with naval operational centres in the region, NATO and the EU, as well as to increase their own capacities receiving data from new sensors. Docking and repair works on patrol vessels P-33 and P-34, have currently been implemented, the preparatory works have been started and the first dockings of the ships for conversion from former missile gunboats, class "Končar" (RTOP- 405 and 406) into smaller patrol boats at the "Jadransko brodogradilište" shipyard in Bijela. The study of the conversion of the RTOP ships to patrol boats was conducted by the most reputable institution in the region, namely the "Brodarski institut" institute from Zagreb. In this way, we are looking for new opportunities to have a required number of vessels at sea in the coming period. This segment of security will become even more topical and certainly more interesting when Montenegro starts research on oil and gas in our seabed, where the Navy will certainly have a great role to play in providing a secure environment for these works and preventive actions on potential problems of sea pollution.

Through intensified regional cooperation, it has been planned that regional capabilities are built in certain segments in response to certain challenges, such as ecology and protection from sea pollution, forces for humanitarian mine clearance of unexploded ordnance (UXO) at sea etc. Also very important is the fact that Montenegro has sea border with three NATO countries, and it is quite clear that the integration into the collective security system will significantly improve maritime security of Montenegro. 


\subsection{Participation of the Armed Forces of Montenegro in international missions and operations}

Representatives of Montenegro were for the first time deployed in a peacekeeping mission in January 1897, with the task of separating the warring Greek and Turkish forces. The Montenegrin armed forces were not accidentally chosen. Europe was aware of their war experience, heroism and appreciated the traditional honesty of Montenegrins. Exactly such armed forces could maintain peace on the island of Crete, where the Turks and the Greeks were fighting for control over this Mediterranean island (Babić, 2006, p. 6). And today, after 112 years, the interests of Montenegro for participation in peacekeeping missions and international activities have been reactivated in 2009. In the $21^{\text {st }}$ century, Montenegro is aware of the importance of collective security. In accordance with its capacities, it strives to contribute to global security by sending its members to international missions and operations.

The Armed Forces of Montenegro is currently engaged in four international missions/ operations:

- International Security Assistance Force - ISAF in Afghanistan until the $31^{\text {st }}$ of December, 2014, and the Resolute Support Mission from the $1^{\text {st }}$ of January, 2015;

- Naval Forces of the European Union - EU NAVFOR ATALANTA in the waters of the Gulf of Aden off the coast of Somalia,

- The European Union Training Mission in Mali - the EUTM and

- The United Nations Mission in Liberia - UNMIL

For members of the MNE AF, the participation in international missions and operations above all represents a professional challenge; moreover, it means further training and education, as well as exchange of experiences with colleagues from the international environment. For the AF of Montenegro, the participation in the missions means the development of interoperability and ability to acquire new experiences and lessons learned which are later used in the training of units. There are $17 \%$ of members of the MNE AF who have participated in a mission, which has largely contributed to the process of achieving interoperability and development of skills in a faster and more efficient way.

After Montenegro received the invitation to join the NATO alliance at the ministerial meeting of the North Atlantic Council in Brussels on the $2^{\text {nd }}$ of December, 2015, in the text of conclusions of the meeting the need was stressed for further adaptation of the defence system of Montenegro with other members of NATO in the forthcoming period before the official membership. One of the key needs of the defence system will be the building of the necessary human resource capacities and competencies in favour of smooth integration into the organizational structure and functioning of NATO. 


\subsection{Membership Action Plan - MAP and Montenegro}

Montenegro started with MAP programme at the meeting of NATO foreign ministers, on the $4^{\text {th }}$ of December, 2009. MAP includes the development of Annual National Programmes - ANP and is unlimited in terms of time. The annual cycle ends with the adoption of the Progress Report, which must be approved by all member states of the Alliance. The first Annual National Programme of the Government of Montenegro was adopted on $16^{\text {th }}$ of September, while on $28^{\text {th }}$ of October 2010, it was presented at a meeting of the North Atlantic Council - NAC, in Brussels, when its implementation officially started. The first ANP of Montenegro defined status in five sections: a) Political and economic issues; b) Military and defence issues; c) Resources; d) Safety issues, and e) Legal issues.

In the four-year period from 2010 - 2014, four ANPs were implemented and progress was made in the given areas. In accordance with NATO's request to place the emphasis on key areas of reform - reform of the defence and security sector, strengthening of the rule of law and strengthening of the public support for Montenegro's membership in NATO, the structure of the IV Annual National Programme has been modified in accordance with the previous three documents, in order to clearly reflect the priorities of Montenegro and monitor activities in fulfilling them.

On this basis, the IV ANP, unlike the First ANP has seven chapters: I - Political Affairs, II - Rule of Law, III - Parliamentary reform, IV - Security Matters, V Military and Defence Matters, VI - Economic issues, and VII - Legal issues.

The Ministry of Defence has been in charge of the planning and implementation of the chapters regarding military and defence issues, and it has been implementing the comprehensive reform of the defence system through the development of military capabilities which are required in order to take over the obligations of full membership in NATO. The implementation of the III package of Partnership Goals as a key priority for achieving the required level of interoperability with allies and partners, and the implementation of the Strategic Defence Review through the compilation of Defence Long-Term Development Plan are given in the IV Annual National Programme and among other things, defined as priorities of the Ministry of Defence. At the meeting of the North Atlantic Council (NAC) with Montenegro, which was held on $18^{\text {th }}$ of June, 2014 at NATO Headquarters in Brussels, the achievements of Montenegro in the framework of the fourth cycle of the Membership Action Plan were presented, and the fourth cycle of MAP was closed.

At the NATO Summit held in Wales, UK on $4^{\text {th }}$ and $5^{\text {th }}$ of September, 2014, with the participation of Montenegrin delegation headed by Prime Minister Milo Djukanović, Montenegro's progress was commended and the decision from the ministerial meeting in June was confirmed that by the end of 2015 a decision would be reached on Montenegro's ability to join NATO. In this respect, intensified and focused talks will continue with Montenegro in order to improve results in the four mentioned areas. 
Paragraph 95 of the final declaration at the NATO Summit in Wales reads: »We welcome the significant progress made by Montenegro in its reforms, its constructive role in the Western Balkans region and the contribution that it makes to international security, including its contribution to our engagement in Afghanistan. In recognition of Montenegro's progress towards NATO membership, the Alliance has agreed to open intensified and focused talks with Montenegro, and agreed that Foreign Ministers will assess Montenegro's progress no later than by the end of 2015 with a view to deciding on whether to invite Montenegro to join the Alliance. These talks will be conducted in conjunction with the Membership Action Plan (MAP) process. In the meantime, we look to Montenegro to continue its efforts to address the remaining challenges, particularly with respect to the rule of law and the completion of the security sector reform. We also welcome the increase in public support in Montenegro for NATO membership and encourage continued efforts in this area."

Based on these defined goals, the fifth ANP was made and presented in Brussels on $17^{\text {th }}$ of October, 2014 at the NAC meeting, at the level of Deputies Committee (DPRC), which was positively assessed by NATO.

Immediately after that, on $27^{\text {th }}$ of October, 2014, in Montenegro, Budva, there was a meeting of NATO's Military Committee and Montenegro in the $28+1$ format. The meeting was opened by the Chairman of the NATO Military Committee General Knud Bartels. General Bartels stressed that the visit of the Military Committee was part of intensified and focused talks with Montenegro. He also commended the continuous efforts of Montenegro invested in the implementation of the Planning and Review Process - PARP, Partnership Goals and overall results achieved in the building of the defence system.

Bearing in mind the results achieved in key areas, particularly those related to the development of the defence system, NATO Secretary General Jens Stoltenberg, on the basis of decisions taken at the meeting of Foreign Ministers of the NAC on $2^{\text {nd }}$ of December, 2015, presented Montenegro with an invitation for membership in NATO.

Conclusion As it is stressed in the beginning of this paper, the contemporary Montenegro's defence system is built in accordance with the strategic determinations of NATO and national interests of Montenegro. By joining the collective defence system such as NATO, nations primarily provide defence of their own territory according to Article 5 of the North Atlantic Treaty. In addition, NATO membership provides member states with a series of advantages based on their individual specificities. The basic advantages of Montenegro's membership in NATO are reflected in the following aspects:

Firstly, one of the most important questions in the process of Euro-Atlantic integration is what the state gains by joining NATO. For Montenegro, the preservation of territorial integrity and sovereignty is of crucial importance. Having in mind the very 
negative experiences from the Montenegrin past, when it lost its independence in 1918, although during the First World War Montenegro was on the side of the Allies (Raspopović, 1996, pp. 23 - 29), NATO membership for Montenegro, as a small country, is of vital national interest. The experience of European countries, which have been NATO members since 1949 together with Canada and the US, shows that they have never in their history spent a longer period of time in peace and experienced less direct threat to their sovereignty and territorial integrity (Vukadinović, Čehulić, Božinović, 2007, p. 132). In the modern world, there is no country which could cope with security challenges alone, and in particular, not countries with limited capacities and resources such as Montenegro. The risks to security are not always clearly visible, and small country experiences teach us that collective security is the best answer to many contemporary security threats. With NATO membership Montenegro permanently retains full sovereignty and territorial integrity.

Secondly, through the process of Euro-Atlantic integration, the reform and development of all elements of the national security of Montenegro, and especially the defence system are significantly cheaper, while at the same time their level of effectiveness is much higher. There is a possibility of different expert services and assistance to overcome our weaknesses and improve our capabilities. At the same time, the possibility of using resources for education and training of the personnel of the Armed Forces of Montenegro and other elements of the security system at well-known academies, schools, training centres and various security institutions of NATO is of great importance for Montenegro. After gaining independence from the former common states, administrative and defence resources and capabilities of Montenegro were very modest, which now makes it highly dependent. Membership in an alliance such as NATO, which operates on the principles of solidarity and mutual assistance, is therefore extremely significant.

Thirdly, in financial terms, the costs of joining NATO are incomparably smaller than those a state would have to set aside if it developed its own defence system. For a small country such as Montenegro, the calculation is clear. By entering NATO Montenegro receives the most security for the least money. For Montenegro, NATO means the application of the smart defence system. This implies the efficient structure of the AF of Montenegro and other parts of the security sector, which will develop specialized capabilities. The rest will be replaced by a collective defence system. Such approach is more cost-effective than the development of a total defence system for which there are no human or material resources. NATO security development programmes - NSIP provide finances for various programmes which are being used in member states and whose value is particularly important when it comes to a small country like Montenegro, and much greater than the membership fee. It is an opportunity for the development of the entire social infrastructure, especially in the field of security.

Fourthly, for the first time in the history of human society a small country like Montenegro has been given the opportunity to sit at the same table with large and 
powerful nations and make decisions that are consistent with their national interests. Additionally, the decision-making system in NATO enables both small and large nations to equally influence the decision-making. Throughout the history, it has been proven repeatedly that Montenegro was not able to influence the events and decisions which were completely in contrast with its desires and needs. Being in the company of the most powerful countries operating on identical values of democracy, rule of law and human rights and freedoms is of crucial importance for a country such as Montenegro, which tends to develop its infrastructure, very impoverished economy and the society as a whole.

Lastly, it is not possible to find the answer to modern challenges and threats independently. Cybercrime and terrorism represent one of the major global threats to modern security. NATO is the only organization which is dealing with this kind of threat in a systematic and professional way and has developed a system of cyber defence. The NATO Computer Incident Response Capability - NCIRC protects NATO's own networks offering centralized 24-hour cyber-defence support to various websites of NATO members.

Also, the assistance in emergency situations is of inestimable importance for Montenegro. Montenegro as a NATO member will provide to its citizens the application of the highest standards in the building of a system for the prevention of civil disasters and recovery from their possible aftermath. The assistance to member states in such situations is set high on the list of NATO priorities. The citizens of our country experienced this in 2012 during the heavy snowfalls. In the event of emergency, NATO provides its members with maximum assistance. In the situations where weather is the decisive factor for rescuing human lives and properties, NATO guarantees to its member states the most efficient organization in the provision of all types of assistance, from coordination and crisis management up to the engagement of special teams and delivery of the necessary means and equipment as soon as possible.

Having all this in mind, it can be concluded that participation in the process of EuroAtlantic integration has unmeasurable value for further development of the defence system of Montenegro and that NATO membership of the country represents the most rational model of defence against various modern threats and challenges.

\section{Bibliography}

1. Grizold, A., Čehulić, L., 2006. Međunarodna sigurnost i NATO u novom svjetskom poretku, Fakultet političkih znanosti, Zagreb, p. 21

2. Babić, B., 2006. Kritski Odred - „Međunarodna mirovna misija Crnogoraca na Kritu 1897-1899“, CID, Podgorica, p. 6.

3. Djurović, G., Čehulić, L., Tahirović, M., Jaćimović, D., Milović, N., 2010. Crna Gora u 21. stoljeću u eri kompetitivnosti - Integracija u evropske i evroatlantske strukture, Crnogorska akademija nauka i umjetnosti 73/4, Podgorica, pp. 161-218. Link: http:// www.gov.me/files/1269953473.pdf 
4. Djurovic, G., 2009. Montenegro 's Strategic Priorities on the Path of Euro-Atlantic Integration, Connections, The Quarterly Journal, Partnership for Peace Consortium of Defence Academies and Security Studies Institutes, Winter, Garmisch-Partenkirchen, pp. 9-39.

5. Mijović, T., 2008. NATO usvojio PARP procjenu za Crnu Goru, Mjesečniko evroatlantskim integracijama, odbrani i vojsci-Partner, No. 3, Podgorica, pp. 9-10. Link: http://www.odbrana.gov.me/Rubrike/casopis-partner.

6. Mijović, T., 2008. Revizija IPP aktivnosti-dokaz odgovornosti i zrelosti, Mjesečnik o evroatlantskim integracijama, odbrani i vojsci-Partner, No. 8, Podgorica, oktobar, pp. 9 - 10.http://www.odbrana.gov.me/Rubrike/casopis-partner.

7. Tahirović, M., 2008. Montenegro and Partnership for Peace Program, Connections, The Quarterly Journal, Partnership for Peace Consortium of Defence Academies and Security Studies Institutes, Spring, Gramisch-Partekirchen, pp. 16 - 42.

8. Tahirović, M., 2010. Crna Gora na putu u NATO, Uprava za kadrove Crne Gore, Podgorica, p. 58.

9. Link:http://www.uzk.co.me/images/stories/publikacije/dokumenti/Crna_Gora_na_putu_u_ NATO.pdf

10. Tahirović, M., Petrič, R., 2015. Integracija Crne Gore u NATO, Uprava za kadrove Crne Gore, Podgorica, pp. $117-118$.

11. Link:http://www.uzk.co.me/images/stories/publikacije/dokumenti/Integracija Crne Gore u NATO.pdf

12. Tahirović, M., 2008., Proces planiranja i revizije - PARP, Mjesečnik o evroatlantskim integracijama, odbrani i vojsci-Partner, No. 3, Podgorica, pp. $9-10$.

13. Link: http://www.odbrana.gov.me/Rubrike/casopis-partner.

14. Tahirović, M., 2008. Strategijski pregled odbrane-analiza resursa i odgovora, Mjesečnik o evroatlantskim integracijama, odbrani i vojsci-Partner, No. 4, Podgorica, pp. 9-10. Link:http://www.odbrana.gov.me/Rubrike/casopis-partner.

15. Vukadinović, R., Čehulić, L., Božinović, D., 2007. NATO Euroatlantska integracija, Zagreb, pp. 132.

16. Raspopović, R., 1996. Diplomatija Crne Gore 1711 do 1918, Podgorica, pp. 23 - 29. 


\section{GOSTUJOČI OBRAMBNI ATAŠEJI: PREDNOSTI IN POMANJKLIVOSTI}

\section{ROVING DEFENCE ATTACHÉS: ADVANTAGES AND DISADVANTAGES}

Povzetek V sodobni obrambnodiplomatski praksi vse pogosteje zasledimo gostujoče obrambne atašeje. V večini držav so se pojavili kot posledica pritiskov po racionalizaciji diplomatske dejavnosti. V prispevku proučujemo prednosti in pomanjkljivosti gostujoče diplomacije, pri čemer poskušamo slednje relativizirati predvsem z vidikov naglega tehnološkega razvoja ter spremenjene miselnosti v mednarodnih odnosih na obrambnem področju. Izmed številnih prednosti največ pozornosti namenjamo vlogi gostujočih obrambnih atašejev v funkciji razvoja karierne diplomatske poti.

Ključne besede

Abstract In modern defence-diplomacy practice, we increasingly encounter roving defence attachés. In the majority of countries, they emerged as a result of the pressures to streamline diplomatic activities. In this paper, we study the advantages and disadvantages of roving diplomats, while trying to relativize the latter mainly from the point of view of rapid technological development and changed mind-set in international defence-related relations. Among the many advantages, major attention is devoted to the role of roving defence attachés in the development of diplomatic career paths.

Key words Diplomacy, defence diplomacy, roving defence attachés. 
Uvod Z zadnjo finančno krizo in gospodarsko recesijo so se povečale zahteve po racionalizaciji obrambnodiplomatske dejavnosti, vse več držav pa se po analogiji s tako imenovanimi letečimi veleposlaniki, ki pomenijo širše uveljavljeno in znano prakso v skandinavskih državah, odloča za akreditacije gostujočih obrambnih atašejev.

Razumljivo je, da se že v izhodišču pogosto postavlja vprašanje, ali so gostujoči obrambni atašeji funkcionalna oblika obrambnodiplomatskega delovanja, ki jo je smiselno vpeljati, uporabljati in razvijati. Najbolj nepremišljena opažanja in razumevanja so gotovo tista, ki imajo gostujoče pokrivanje le za boljše kot nikakršno. S tem se je težko strinjati, saj kakršna koli oblika akreditacije prinaša neke obveznosti in pričakovanja, ki jih je treba korektno in vestno izvajati. Gostujoči obrambni atašeji so glede diplomatskega statusa, privilegijev in imunitet izenačeni z rezidenčnimi diplomati, zaradi česar so tudi pričakovanja enakovredna in visoka.

V teoriji in praksi se največ pozornosti namenja zaskrbljenosti nad pomanjkljivostmi gostujočih atašejev, zato se pogosto zgodi, da povsem nenamerno prezremo njihove prednosti, pa čeprav so tudi slednje številne ter prinašajo zelo konkretne in neposredne učinke. V prispevku podrobneje predstavimo obe kategoriji, in sicer v razmerju do rezidenčnih diplomatov, ki ostajajo temeljni postulat obrambnodiplomatske prakse. Primerjavo razvijamo skozi dejavnost, vlogo in naloge sodobne obrambne diplomacije, ki se pod vplivom tehnološkega razvoja in spremenjene miselnosti v mednarodnih odnosih hitro in korenito spreminja, spremenjene okoliščine pa so delovanju gostujočih obrambnih atašejev vse bolj naklonjene.

\section{OBRAMBNA DIPLOMACIJA}

Diplomacija je družbena dejavnost in politični proces, skozi katerega politični udeleženci, najpogosteje države, stopajo v medsebojne odnose v mednarodnem okolju (Vukadinović, 1995, str. 110). Glede na ožji predmet obravnave se pojavljajo posebne vrste diplomacije, na primer ekonomska, gospodarska in kulturna, pa tudi obrambna. Področje delovanja slednje je veliko ožje in specializirano glede na splošno, visoki vojaški častniki in generali, ki to zvrst diplomacije opravljajo, pa naj bi poleg splošnega diplomatskega znanja in spretnosti premogli tudi specifično znanje z obrambnega in vojaškega področja.

Definicija, ki je značilna predvsem za anglosaške države, šteje za obrambno diplomacijo mirnodobno uporabo oborožene sile in z njo povezane infrastrukture kot orodja zunanje in varnostne politike ter vojaškega sodelovanja in pomoči (Aziri, 2012). Kocbek (1997) obrambno diplomacijo opredeljuje kot mirnodobno, normativno in usmerjeno diplomatsko oziroma zunanjepolitično dejavnost vlade, ki vključuje uporabo obrambnih in vojaških struktur zunaj državnega ozemlja. Njen cilj je krepitev obrambnega in vojaškega sodelovanja za graditev medsebojnega zaupanja ter večjo stabilnost in varnost v svetu. 
Številna razmišljanja v definicijo strne tudi Jazbec (2007), ki trdi, da je (dvostranska) obrambna diplomacija tista, ki:

- se kot dejavnost ukvarja z izvajanjem obrambne in vojaške ter tudi varnostne zunanje politike države pošiljateljice;

- ima za predmet obdelave vojaško-obrambne strukture države sprejemnice;

- ima namen vzpostavljati, razvijati in poglabljati odnose ter sodelovanje med tovrstnimi strukturami obeh držav;

- jo kot nosilec izvaja poseben diplomat, specializiran v poznavanju in obvladovanju vojaško-obrambnih zadev;

- pri svojem delu uporablja običajne diplomatske metode, ki so deloma prilagojene posebnostim področja, na katerem deluje;

- in katere izvajalec oziroma nosilec v diplomatskem predstavništvu deluje kot član osebja (kar na primeru gostujočih obrambnih atašejev velja le deloma).

Zanimiv pogled na obrambno diplomacijo predstavi Ogorec (2005), ki našteva osnovne naloge obrambnodiplomatskih predstavništev oziroma obrambnih atašejev:

- predstavljanje oboroženih sil in ministrstva za obrambo države pošiljateljice v državi sprejemnici;

- zaščita interesov države in oboroženih sil države pošiljateljice v državi sprejemnici (zaščita integritete pripadnikov, ki so v državi sprejemnici na različnih šolanjih in skupnih vojaških vajah ali skozi državo potujejo);

- zbiranje podatkov o oboroženih silah države sprejemnice;

- razvoj in krepitev dvostranskega sodelovanja na obrambnem in vojaškem področju, skladno z usmeritvami države pošiljateljice;

- svetovalna vloga: svetovanje veleposlaniku glede vprašanj vojaške narave.

\section{NAČINI AKREDITACIJE IN VRSTE OBRAMBNIH ATAŠEJEV}

Glede na način akreditacije razlikujemo tri vrste obrambnih atašejev:

- rezidenčne, ki začasno bivajo na ozemlju države, v kateri so akreditirani in so torej njeni rezidenti, naloge pa opravljajo na diplomatskem predstavništvu države pošiljateljice $\mathrm{v}$ državi sprejemnici. MO RS ima akreditiranih osem rezidenčnih obrambnih atašejev, in sicer $\mathrm{v}$ Bosni in Hercegovini, Italiji, na Kitajskem, v Nemčiji, Rusiji, Srbiji, Turčiji in ZDA;

- nerezidenčne, ki niso rezidenti države, v kateri so akreditirani, diplomatsko dejavnost pa opravljajo iz katere izmed sosednjih ali okoliških držav, vendar ne iz države pošiljateljice. Slovenski rezidenčni atašeji v obliki nerezidenčnih akreditacij pokrivajo osem držav: Dansko in Poljsko iz Berlina, Španijo iz Rima, Romunijo in Makedonijo iz Beograda, Kanado iz Washingtona ter Azerbajdžan in Libanon iz Ankare; 
- gostujoče ${ }^{1}$ oziroma nerezidenčne, s sedežem v državi pošiljateljici. Diplomatsko dejavnost izvajajo iz matične države, delovno mesto pa je sistemizirano v okviru ministrstva za obrambo, generalštaba oboroženih sil ali obveščevalnovarnostne službe. Na MO RS delujeta dva gostujoča atašeja. Prvi je akreditiran v Avstriji, Združenem kraljestvu, Švici in na Norveškem, drugi pa na Hrvaškem in Madžarskem.

Razlik glede postopkov akreditacije, statusa ${ }^{2}$ ter nalog in zadolžitev med posameznimi vrstami obrambnih atašejev ni, obstajajo pa razlike glede načinov ter temeljnih pristopov obrambnodiplomatskega delovanja.

V zadnjem času več predvsem zahodnoevropskih držav v obrambnodiplomatsko dejavnost vključuje gostujoče obrambne atašeje. Poglavitne razloge moramo iskati v dejstvu, da je bila zaradi vpliva svetovne gospodarske recesije in finančne krize večina obrambnih in vojaških sistemov prisiljena v občutno znižanje porabe, pri čemer so nekatere države prihranke iskale tudi s preoblikovanjem obrambnodiplomatskega pokrivanja, in sicer predvsem z ukinjanjem uradov rezidenčnih obrambnih atašejev. Ker so želele ohraniti določeno stopnjo diplomatskih stikov, so se odločile za gostujoče obrambne atašeje.

Po drugi strani so nekatere države zaradi širjenja članstva $\mathrm{v}$ mednarodnih organizacijah, predvsem v zvezi Nato in EU, vse več pozornosti začele namenjati in usmerjati v večstransko diplomacijo ter se pri tem zanašale, da bodo tudi zadeve $\mathrm{v}$ dvostranski domeni koordinirane in vodene prek nacionalnih obrambnih in vojaških predstavništev pri mednarodnih organizacijah. Praksa je hitro pokazala, da ni tako. Obseg dela $\mathrm{v}$ multilateralni diplomaciji je že $\mathrm{v}$ okviru rednih nalog intenziven, poleg tega pa so med dvostransko in večstransko diplomacijo pomembne razlike v načinih delovanja, zaradi česar obrambni predstavniki »klasične« diplomacije po večini niso vešči in spretni. Posledično so se države odločala, da obnovijo inštrumente dvostranske obrambne diplomacije, da njihove predhodne odločitve in poteze ne bi izpadle naivne in nepremišljene, pa so začele vzpostavljati mreže gostujočih obrambnih atašejev, ki predstavljajo nekakšen kompromis v primerih, ko rezidenčnega pokrivanja niso bile sposobne ponovno zagotoviti.

Z vidika gostujočih obrambnih atašejev je zanimiva študija Ženevskega centra za demokratični nadzor nad oboroženimi silami (DCAF) iz leta 2007, ki je raziskovala reformne smernice obrambne diplomacije po koncu hladne vojne. Obstajali naj bi

\footnotetext{
Za zdaj še nimamo enotnega termina ne v slovenskem ne v angleškem jeziku. V angleškem izrazoslovju se kot najbolj pogosta uporablja oznaka »roving" (potepanje, klatenje), redkeje pa »travelling « (potujoči) ali »laptop « (glede na prevladujočo vrsto računalnika, ki ga na pogostih službenih poteh uporabljajo). Na Madžarskem uporabljajo oznako regionalni ataše. Priročen je tudi izraz »roaming « (izposojen iz mobilne telefonije; gostovanje v tujini), iz katerega izhaja slovensko poimenovanje - gostujoči ataše.

2 Pravilnik o uslužbencih na obrambnem področju, ki začasno opravljajo delo v diplomatskih predstavništvih RS $v$ tujini, 3. člen, 5. odstavek: Uslužbenec na obrambnem področju, izenačen z diplomati, je v času, ko opravlja naloge obrambnega atašeja izven ozemlja RS, tudi gostujoči obrambni ataše, ki je akreditiran kot nerezidenčni obrambni ataše v sprejemnih državah s sedežem v Ljubljani.
} 
dve skupini držav. V prvi so tiste, katerih obrambnodiplomatski sistemi so zadnja desetletja ostali večinoma nespremenjeni. To so predvsem države, ki obrambno diplomacijo še naprej uporabljajo v glavnem za izvajanje obveščevalne dejavnosti. Druga skupina so članice zveze Nato in EU, katerih obrambnodiplomatske mreže so prešle znatne spremembe in prestrukturiranje, pri čemer rezultati raziskave nakazujejo šest osnovnih usmeritev:

- od dvostranskih obrambnih atašejev k večstranskim obrambnim predstavnikom pri regionalnih in mednarodnih organizacijah, kot so EU, OZN in zveza Nato;

- akreditacije v državah v razvoju namesto v razvitih državah; zavezništva, kot sta zveza Nato in EU, zmanjšujejo potrebo po vzajemnih akreditacijah obrambnih atašejev med članicami, odpirajo pa se uradi obrambnih atašejev v državah na Bližnjem vzhodu ter v Afriki in Aziji oziroma v državah, ki pridobivajo strateški pomen;

- od akreditacij v le eni državi k akreditacijam v več državah;

- od rezidenčnih obrambnih atašejev h gostujočim atašejem;

- od stalnih akreditacij k začasnim, časovno omejenim na projekt ${ }^{3}, \mathrm{v}$ okviru katerega je zaželena, potrebna ali koristna akreditacija obrambnega atašeja;

- od obrambnih atašejev k varnostnim (s širšega varnostnopolitičnega vidika so varnostni atašeji nekakšna kombinacija obrambnega in policijskega atašeja).

Poleg splošne usmeritve, ki govori o krepitvi gostujočih obrambnih atašejev, pa velja z vidika študije DCAF kot priporočilo izpostaviti tudi prizadevanja po akreditacijah $\mathrm{v}$ čim več državah in projektnih akreditacijah.

\section{POMANJKLJIVOSTI GOSTUJOČIH ATAŠEJEV}

V nadaljevanju predstavljamo pomanjkljivosti gostujočih obrambnih atašejev, hkrati pa poskušamo prepoznati načela in vzorce sodobnega diplomatskega delovanja, ki posamezne izmed njih relativizirajo, ublažijo ali odpravijo. Ob tem se je treba zavedati, da večina izmed naštetih pomanjkljivosti velja tudi za nerezidenčne obrambne atašeje.

Sistematičen pregled glavnih izzivov delovanja gostujočih atašejev dobimo, če nanje pogledamo skozi osnovne naloge obrambne diplomacije, ki sta jih definirala ter podrobno opredelila Nick (1997) in Sežun (2010). Po njunem mnenju obrambni atašeji opravljajo dve vrsti nalog: strokovno-funkcionalne in reprezentativno-protokolarne.

V okviru strokovno-funkcionalnih nalog obrambni ataše opravlja obveščevalno funkcijo (zbira podatke in pripravlja poročila o obrambno-vojaških aktivnostih države sprejemnice) ter komunikacijsko funkcijo (vzpostavlja in usmerja stike, ki so podlaga za povezovanje in sodelovanje). V okviru obeh funkcij gostujoči ataše nedvomno občuti določen primanjkljaj, ki izvira iz nestalne prisotnosti v sprejemni državi.

3 Kot primer lahko navedemo akreditacijo madžarskega obrambnega atašeja na Švedskem, v času, ko je podjetje Saab madžarskim obrambnim silam dobavljalo lovska letala JAS-39 gripen (Gombos, 2015). 
Le občasna prisotnost $\mathrm{v}$ sprejemni državi je glavna ovira, da gostujoči ataše veliko težje vzpostavi pristno, osebno in neformalno komunikacijo s predstavniki obrambnega ministrstva ter pripadniki oboroženih sil kot tudi drugimi predstavniki obrambnodiplomatskega zbora. Zaradi navedenega dejstva gostujoči obrambni atašeji po mnenju Zupančiča (2010) niso zmožni in sposobni vzpostavljanja socialnih in strokovnih mrež.

Pogosto se pomembne informacije oblikujejo in širijo prav v okviru omenjenih struktur ter razmeroma zaprtih skupin diplomatov in obrambnih strokovnjakov, do katerih imajo gostujoči atašeji omejen dostop. Hkrati se je treba zavedati, da je tudi dostop do ustreznih ravni odločanja pogosto odvisen predvsem od kakovosti kolegialnih in prijateljskih odnosov, pri čemer navedene omejitve prinašajo dodatne izzive pri vzpostavljanju pristnih osebnih stikov.

Pomanjkljivosti gostujočih atašejev z vidika dostopa do informacij in učinkovite komunikacije se relativizirajo ob dejstvu, da se je vloga obrambne diplomacije $\mathrm{v}$ minulih letih bistveno spremenila. Kot ugotavlja Tratnik (2012), so tehnični napredek ter razmah in množična uporaba svetovnega spleta omogočili večji in hitrejši dostop do skoraj vseh podatkov in informacij, pri čemer jih tudi obrambni atašeji vse več pridobijo iz javnih virov. Na tej podlagi se avtorica utemeljeno vpraša, ali bodo $\mathrm{v}$ prihodnosti obrambnodiplomatski predstavniki v državi sprejemnici (rezidenčni atašeji) sploh še potrebni.

Zaradi razmaha medijev množičnega obveščanja, dostopnosti interneta ter premika miselnih vzorcev od nezaupanja ter odkritih vojaških napetosti in konfrontacij $h$ kulturi sodelovanja in partnerstva (še posebej v okviru zavezništev) v sodobnem svetu obstajajo le še redke informacije, ki niso javno dostopne. Če je obrambni ataše še v času hladne vojne z vsemi dovoljenimi in nedovoljenimi sredstvi pridobival informacije, na primer o številu oklepnih bojnih vozil (tipih oborožitve in količinah), ki jih poseduje neka država, $\mathrm{v}$ sodobnem času zadostuje že nagel vpogled $\mathrm{v}$ spletne baze, za zanesljivejše in verodostojnejše podatke pa listanje specializiranih vojaških almanahov. Obveščevalno funkcijo obrambnih atašejev v pretežni meri opravljajo mednarodne pogodbe o trgovini z orožjem, razoroževanju in nadzoru nad oboroževanjem, z obdobnimi poročanji in mednarodnimi inšpekcijami, medtem ko o stopnji pripravljenosti pričajo udeležbe na mednarodnih vojaških usposabljanjih in vajah.

Podobno idejo zasledimo pri Zupančiču (2010, str. 68), ki trdi, da je spekter nalog vojaških diplomatov zelo širok, a se skozi čas spreminja. Prevladujoča obveščevalna funkcija, ki je bila značilna od začetkov vzpostavitve tovrstnega inštituta do konca hladne vojne, izgublja pomen, nadomešča pa jo komunikacijska funkcija, ki je bistvena za povezovanje in sodelovanje. Obveščevalno dejavnost prvenstveno in neposredno izvajajo pristojne obveščevalne službe, ki jih atašeji samo občasno dopolnjujejo in jim pomagajo pri iskanju ustreznih virov informacij. 
Sodobne tehnologije vnašajo korenite spremembe na področje komunikacij in vplivajo tudi na komunikacijsko dejavnost obrambnih atašejev. Uradne diplomatske note nadomeščajo in izpodrivajo poluradna sporočila, ki so posredovana po elektronski pošti, različnih mobilnih aplikacijah ali celo družabnih omrežjih. V duhu tesnega sodelovanja in partnerstva delovna komunikacija navadno ne poteka več prek kodiranih in strogo varovanih omrežij, če že, pa tudi slednja omogočajo bistveno večjo prilagodljivost glede ustvarjanja in sprejemanja sporočil. Hkrati so na voljo nova sredstva in mediji, kot na primer različne avdio-video povezave ter mobilna podatkovna omrežja, ki omogočajo interaktivno komunikacijo. Kot ugotavlja Mogolič (2004), je za sodobno (postmoderno) vojaško organizacijo značilno, da se odzove na vplive iz civilnega okolja ter tako kot posamezniki in družba kot celota postaja vse manj zaprta, birokratska in hierarhična struktura, v kateri tudi nekdaj dominantne formalne vezi vse pogosteje prehajajo v osebne. $\mathrm{Ob}$ vse tesnejši povezanosti in prepletenosti civilnega in vojaškega okolja ter vse večji internacionalizaciji oboroženih sil postaja tudi komunikacija vse bolj odprta.

Kot pomanjkljivost gostujočih atašejev v okviru funkcionalnih nalog velja izpostaviti zaščito integritete pripadnikov oboroženih sil države pošiljateljice, ki so v državi sprejemnici na različnih šolanjih ali skupnih vojaških vajah, lahko pa tudi le potujejo čez njeno ozemlje. Ob zapletih, na primer ob zdravstvenih poškodbah ali prometnih nesrečah, so navadno potrebni takojšnji odzivi in ukrepi obrambnega atašeja ter osebna prisotnost na kraju dogodka, česar gostujoči atašeji ne morejo zagotoviti. V njihovo obrambo pričajo podatki, da so izredni dogodki redki, poleg tega pa status oboroženih sil na ozemlju tuje države in nabor ob izrednih dogodkih podrobno določajo predmetni mednarodni pravni sporazumi, tako imenovani sporazumi SOFA $^{4}$ ). Poleg tega lahko posamezniki, da bi se izognili različnim tveganjem, sklenejo ustrezno zavarovanje za tujino. Pri zapletih širšega obsega pa mednarodno diplomatsko in konzularno pravo ${ }^{5}$ omogoča vzpostavitev tako imenovanih specialnih misij. To so začasne misije, ki jih ena država pošilja v drugo zaradi obravnavanja določenih vprašanj ali izvršitve povsem določene naloge. So najstarejša in zelo prožna oblika diplomatskega občevanja, primerna tudi za sodoben tempo življenja (Bohte in Sancin, 2006, 191).

Gostujoči atašeji so omejeni tudi pri opravljanju reprezentativno-protokolarnih nalog. Zaradi le občasne prisotnosti v sprejemni državi se ne morejo udeležiti vseh sprejemov, poročanj, informiranj za visoke goste v okviru vojaških vaj ter podobnih dogodkov, ki jih organizirajo pristojne službe ministrstva ali generalštaba ter tudi posamezna veleposlaništva, ki so prisotna v državi sprejemnici.

Toda skladno s sodobnimi trendi diplomatske dejavnosti se organizira vse manj dogodkov, ki so izključno protokolarne narave, temveč so slednji navadno dodani širšim informativnim poročanjem in aktivnostim strokovnega značaja. Ker so v

\footnotetext{
4 Status of Forces Agreement (SOFA).

5 Dunajska konvencija o diplomatskih odnosih.
} 
nekaterih majhnih državah, vključno s Slovenijo, večinoma akreditirani nerezidenčni in gostujoči atašeji, so jim začeli prilagajati sistem poročanj, pa tudi druge dogodke, vključene v letne programe. To omogoča pravočasno načrtovanje in udeležbo tudi gostujočim atašejem. Kljub vsemu velja opozoriti na potrebo in smiselnost redne prisotnosti gostujočega atašeja v sprejemnih državah, ustrezno organizacijo in razporeditev dela ter oblikovanje prioritet (udeležba na vseh dogodkih ni potrebna). Dodatne priložnosti z vidika obveščanja omogočajo tudi članstva in srečanja v okviru združenj obrambnih atašejev ter delovni sestanki ožjih interesnih skupin, na primer srečanja obrambnih atašejev iz držav članic zveze Nato. Koristen vir informacij so tudi srečanja s starešinami obrambnodiplomatskih zborov.

Kot zadnjo izmed pomanjkljivosti velja omeniti, da akreditacija gostujočega atašeja nalaga dodatne naloge in obveznosti rezidenčnemu veleposlaništvu. Diplomatska praksa določa, da uradna komunikacija poteka na relaciji med MZZ države sprejemnice in veleposlaništvom države pošiljateljice, pri čemer morajo v odsotnosti rezidenčnega atašeja drugi uslužbenci veleposlaništva prevzeti dodatne zadolžitve in obveznosti. V glavnem gre res za rutinske, tehnične in administrative zadeve, na primer posredovanje pošte, vendar pa kljub vsemu zahtevajo resen in odgovoren odziv.

\section{PREDNOSTI GOSTUJOČIH ATAŠEJEV}

V majhnih državah z omejenim diplomatskim aparatom, brez specializiranih izobraževanj in usposabljanj ter diplomatske akademije je lahko glavna prednost gostujočih atašejev njihova vloga $\mathrm{v}$ funkciji razvoja karierne diplomatske poti. Ustrezno organiziran sistem gostujočih atašejev z vzpostavljenim mentorskim odnosom lahko uporabimo za usposabljanje ter izbor kandidatov, ki bodo sposobni kakovostno in učinkovito opravljati najzahtevnejše (rezidenčne) diplomatske naloge. Z razvojem karierne poti skozi gostujoče atašeje bi hkrati pomladili diplomatski zbor, omogočili celovite priprave bodočih rezidenčnih diplomatov, zagotovili polno operativnost ob nastopu funkcije, povečali delovno motivacijo ter preprečili možnosti, da diplomatske funkcije zasedejo neprimerni kandidati, brez izkušenj ter ustreznih znanj in spretnosti. Zavedati se je namreč treba, da lahko zahteven diplomatski poklic uspešno in učinkovito opravljajo le najbolje usposobljeni, strokovni, vestni in predani posamezniki.

Ena izmed najbolj očitnih in najširše prepoznanih prednosti gostujočih atašejev je finančna racionalizacija diplomatskega delovanja. Stroški rezidenčnega obrambnega atašeja zadostujejo za delovanje najmanj treh gostujočih atašejev ${ }^{6}$.

\footnotetext{
${ }^{6}$ Po izračunih finančnih analitikov MO RS so letni stroški slovenskega rezidenčnega obrambnega atašeja v povprečju okoli 150.000 evrov (stroški se med posameznimi atašeji precej razlikujejo, saj so odvisni od velikosti diplomatove družine, števila šoloobveznih otrok ter indeksa cen življenjskih potrebščin v državi sprejemnici), stroški delovanja gostujočega atašeja na letni ravni pa ne presežejo 40.000 evrov.
} 
Gostujoči atašeji so akreditirani v več državah kot rezidenčni. Omenjeno potrjuje slovenski primer, saj so rezidenčni obrambni atašeji v povprečju akreditirani $\mathrm{v}$ dveh državah, gostujoča pa v treh. Mogoče še bolj zgovoren je podatek, da je RS še pred nekaj leti imela rezidenčna obrambna atašeja na Hrvaškem in Madžarskem, akreditirana izključno v sprejemni državi, medtem ko je trenutno v obeh državah akreditiran isti gostujoči ataše.

Nadomeščanje rezidenčnih atašejev z gostujočimi omogoča preusmeritev rezidenčnega pokrivanja na države, $\mathrm{v}$ katerih je diplomatska prisotnost $\mathrm{v}$ nekem obdobju bolj smiselna, potrebna in koristna. Če Avstrija tako krepi rezidenčno prisotnost $\mathrm{v}$ državah na evropski periferiji, na morebitnih kriznih žariščih ter v državah, v katerih se izvajajo mednarodne mirovne operacije s prisotnostjo pripadnikov Avstrijske zvezne vojske (Rottenberger, 2014), pa je Slovenija pozornost preusmerila na države, ki pridobivajo politični in geostrateški pomen. Tako so umiki atašejev iz Budimpešte, Londona, Pariza, Zagreba in Skopja omogočili akreditaciji v Pekingu in Ankari.

Gostujoči ataše ni na nobeno izmed akreditiranih držav vezan življenjsko in bivanjsko ter tako vpet $\mathrm{v}$ njeno vsakodnevno politično, družbeno in kulturno dogajanje. Obstajata namreč past in nevarnost, da rezidenčni diplomat dogajanje $\mathrm{v}$ državi akreditacije in njeni okolici začne spremljati in razumeti predvsem skozi prizmo družbenih in političnih stereotipov ter interesov gostujoče države, zaradi česar so njegova dejanja lahko subjektivna in pristranska. Gostujoči diplomati so pri svojem delu bolj objektivni in vsem državam akreditacije načeloma namenjajo enako ali podobno veliko pozornosti.

Z akreditacijo atašeja iz prestolnice se izognemo negativnim odzivom in diplomatski nejevolji, ki bijih lahko povzročila nerezidenčna akreditacija iz katere izmed okoliških držav, predvsem, kadar so njuni medsebojni odnosi obremenjeni z zgodovinskimi okoliščinami ali nerešenimi vprašanji, ki se v času koakreditacije ${ }^{7}$ lahko šele pojavijo. Na primer Portugalska odkrito zavrača koakreditacije iz Španije (Longar, 2015), pa tudi slovensko zunanjepolitično stališče ni naklonjeno koakreditacijam diplomatov v RS iz Hrvaške. Na splošno so države bolj naklonjene gostujočim akreditacijam kot koakreditacijam, saj slednje vendarle na neki način odražajo razmerje podrejenosti in perifernosti.

Po ugotovitvah Zupančiča (2010) je eden temeljnih izzivov rezidenčnih obrambnih atašejev odstopanje od načela enostarešinstva. Po strokovni liniji je atašeju neposredno nadrejen obrambni minister ali načelnik generalštaba, kot diplomat pa je, vsaj neformalno, podrejen vodji diplomatske misije oziroma veleposlaniku. Slednji v sprejemni državi predstavlja predsednika republike, predsednik republike pa je skladno z Ustavo Republike Slovenije (102. člen, funkcija predsednika

Diplomati so hkrati lahko akreditirani v več državah. Za države zunaj sedeža diplomatskega predstavništva se je uveljavil izraz, da so v njih koakreditirani. 
republike) vrhovni poveljnik obrambnih sil oziroma Slovenske vojske, katere pripadnik je obrambi ataše. Tudi gostujoči ataše je del ekipe veleposlaništva, vendar veleposlaniku ni podrejen. $\mathrm{Z}$ akreditacijo gostujočega atašeja vodjo diplomatske misije izločimo iz linije vodenja oziroma poveljevanja v smislu subordinacije, s čimer se izognemo morebitnim trenjem, nesoglasjem, obtoževanjem in prepirom na relaciji med veleposlanikom in obrambnim atašejem, do katerih lahko prihaja v praksi (predvsem v primerih, ko so za obrambne atašeje imenovani pripadniki najvišjih častniških ali generalskih činov).

Gostujoči ataše v primerjavi s kolegi na oddaljenih lokacijah deli pisarno z najbližjimi sodelavci, neposredno nadrejenimi in vršnim menedžmentom. Glede nalog dobiva na rednih delovnih in strokovnih sestankih natančna navodila in usmeritve, ki se lahko kadar koli dodatno in podrobneje pojasnijo ter razložijo. Omogočena sta mu tudi neposreden dostop do vsebinskih gradiv in široka strokovna podpora. Zaradi neposredne vključenosti opravlja dane naloge zavzeto ter si jih prizadeva dokončati kakovostno in celovito. Hkrati nadrejeni lažje izvajajo nadzor nad njegovim delom ter vzpostavijo konsistentnejša merila delovne uspešnosti in učinkovitosti. Kot potrjuje Jazbec (2007), je za dobro delovanje obrambnih atašejev zelo pomembno, da jih ministrstvo sproti, stalno in natančno inštruira ter jim daje konkretne naloge, kar je gotovo lažje z gostujočimi obrambnimi atašeji.

Kadar se država odloča za prvo napotitev rezidenčnega obrambnega atašeja, jo zlahka lahko zavedejo nerealne ocene ter razkorak med pričakovanji in resničnimi potrebami. Dobro bi bilo preveriti praktično stanje na terenu, kar lahko opravimo S »predhodnico« v obliki gostujočega atašeja. Če se naknadno izkaže, da je rezidenčni ataše nepotreben in nekoristen, navadno izgubimo celoten (večletni) mandat, saj predčasen odpoklic pošilja mešane, predvsem negativne, signale in ga države uporabljajo le izjemoma. Neobičajna je celo akreditacija atašeja za le en mandat. »Preizkušanje terena $\mathrm{z}$ gostujočim atašejem je gotovo najbolj preudarna in racionalna rešitev, saj je njegova akreditacija prilagodljiva ter ima tudi v najslabšem primeru minimalne finančne in diplomatske posledice.

Včasih akreditacija atašeja $\mathrm{v}$ določeni državi na dolgi rok ni potrebna, lahko pa se v nekem trenutku pojavijo specifične okoliščine ali projekti posebnega pomena, ki ustvarijo potrebo po začasni akreditaciji. V tovrstnih primerih je najbolj ustrezna prav akreditacija gostujočega atašeja, ki lahko na kratek rok začne in zaključi svoj mandat, za nastop dela pa niso potrebne daljše priprave, selitev ter vnaprejšnja ureditev namestitvenih in delovnih pogojev. Gostujoči ataše lahko začne opravljati naloge skoraj isti dan, ko mu je izdana akreditacija sprejemne države, ter konča s trenutkom, ko akreditacija ni več potrebna ali koristna.

Gostujoči obrambni atašeji delujejo in bivajo v domačem okolju, kar posameznikom v določenem življenjskem obdobju ustreza bolj, kot bi jim selitev v tujino. V primeru gostujoče akreditacije ni potrebe, da bi se diplomatski dejavnosti prilagodili življenjski cikel in navade celotne družine. Po drugi strani obstaja utemeljeno 
tveganje, da zaradi začasne nezmožnosti ali nezainteresiranosti za selitev v tujino izgubimo kakovostnega kandidata za opravljanje diplomatske funkcije.

Če smo pri pomanjkljivostih ugotovili, da večina prizadene tudi nerezidenčne obrambne atašeje, pa velika večina prednosti pripada le gostujočim atašejem. Pogojno lahko z nerezidenčnimi akreditacijami preverimo potrebo po napotitvi rezidenčnega atašeja oziroma zagotovimo akreditacijo za določen čas ali projekt. Glede prve je dodaten izziv dejstvo, da rezidenčne akreditacije navadno niso zgoščene na prostoru, glede druge pa smo omejeni, če ne zagotavljamo rezidenčnega pokrivanja v neposredni soseščini.

\section{Priporočila in sklepi}

Da gostujoči obrambni atašeji omogočajo funkcionalno obrambnodiplomatsko delovanje, potrjujeta razmeroma bogata praksa ter postopna in vztrajna širitev kroga držav, ki uporabljajo ta koncept. Hkrati države, ki inštitut že uporabljajo, povečini širijo obseg akreditacij.

Analiza delovanja gostujočih obrambnih atašejev na MO RS še ni bila narejena. Da so prve ocene v pretežni meri pozitivne, pa lahko sklepamo na podlagi razmišljanj o širitvi diplomatske dejavnosti z atašeji iz prestolnice. Tovrstni načrti so namreč vključeni v srednjeročni obrambni program, ki je eden izmed temeljnih strateških načrtovalnih in razvojnih dokumentov. Skladno s Srednjeročnim obrambnim programom Republike Slovenije 2016-2020 naj bi se »obrambnodiplomatska mreža prilagodila zunanjepolitičnemu položaju RS in izvajanju nalog SV v spremenjenih mednarodnih politično-varnostnih razmerah $\mathrm{z}$ regionalno naravnanostjo in jasno izraženim težiščem sodelovanja. Zagotovljeni bodo ustrezni kadrovski viri za popolnitev obrambnodiplomatske mreže in intenzivirana uporaba gostujočih (nerezidenčnih) atašejev«.

Ne smemo pa prezreti, da se pri gostujočih atašejih v primerjavi z rezidenčnimi pojavljajo primanjkljaji, pomanjkljivosti, izzivi oziroma težave pri opravljanju tako strokovno-funkcionalne kot reprezentativno-protokolarne funkcije, vendar pa se tovrstna tveganja lahko bistveno zmanjšajo že z ustrezno organizacijo dela. Dodatno jih je mogoče relativizirati z vidika informacijske družbe oziroma širokega dostopa do informacij ter uporabe sodobnih informacijskih in komunikacijskih tehnologij. Da je obrambna diplomacija doživela korenite evolucijske spremembe in postala bistveno manj agresivna, pa je tudi posledica povečanega zaupanja in spremenjene miselnosti mednarodnih odnosov, predvsem po koncu hladne vojne, ki iščejo svoje poslanstvo $\mathrm{v}$ prizadevanjih za povezovanje in sodelovanje.

Hkrati gostujoči obrambni atašeji prinašajo več povsem konkretnih prednosti, pri čemer pa se nekatere pokažejo šele v specifičnih okoliščinah ali povsem konkretno izraženem namenu in interesu. Zato bi veljalo oblikovati jasna pričakovanja ter proučiti specifične dejavnike in parametre posameznih akreditacij, na podlagi katerih 
bi lahko ocenili, ali bo akreditacija gostujočega obrambnega atašeja v sprejemni državi omogočala funkcionalno opravljanje diplomatskih nalog.

Kot eno izmed glavnih prednosti gostujočih atašejev velja izpostaviti morebitno vlogo v funkciji razvoja karierne diplomatske poti. Diplomat bi v pisarno gostujočih atašejev vstopil kot pripravnik, se usposobil in izpopolnil, prevzel rezidenčno diplomatsko funkcijo ter se v pisarno gostujočih atašejev vrnil kot mentor. Tako bi v postopke izbire bodočih diplomatov vnesli več transparentnosti in izkoreninili pogosto negativno kadrovsko selekcijo.

\section{Literatura}

1. Aziri, F., 2012. Obrambna diplomacija kot sredstvo zagotavljanja varnosti - Primer Republike Makedonije (Magistrsko delo). Ljubljana: Fakulteta za družbene vede.

2. Bohte, B. in Sancin, V., 2006. Diplomatsko in konzularno pravo. Ljubljana: Cankarjeva založba.

3. Defence Attachés, DCAF Backgrounder Series, 2007. Ženeva: Geneva Centre for the Democratic Control of Armed Forces.

4. Dunajska konvencija o diplomatskih odnosih, 2013. Uradni list RS (9).

5. Gombos, A., 2015. Intervju o organizaciji sistema gostujočih obrambnih atašejev na Madžarskem. Ljubljana, 8. september 2015.

6. Jazbec, M., 2007. Vojaška in obrambna diplomacija. Ljubljana: Fakulteta za družbene vede.

7. Kocbek, A., 2007. Preoblikovanje obrambne diplomacije. Bilten Slovenske vojske, 9 (1), 73-90.

8. Longar, M., 2015. Intervju o izkušnjah »letečega« veleposlanika. Ljubljana, 3. november 2015.

9. Mogolič, F., 2004. Rituali v vojaški organizaciji (Diplomsko delo). Univerza v Ljubljani: Fakulteta za družbene vede.

10. Nick, S., 1997. Diplomacija: Metode i tehnike. Zagreb: Barbat.

11. Ogorec, M., 2005. Vojno-diplomatska praksa. Zagreb: Golden marketing-tehnička knjiga.

12. Pravilnik o uslužbencih na obrambnem področju, ki začasno opravljajo delo v diplomatskih predstavništvih Republike Slovenije v tujini, 2011. Interni pravni akt Ministrstva za obrambo Republike Slovenije.

13. Rottenberger, N., 2014. Militärdiplomatie: Verteidigungsattaché Roving Ein flexibles Modell der Militärdiplomatie. Truppendienst, št. 342 (6/2014), 514-519.

14. Sežun, D., 2010. Spreminjanje vloge vojaškega atašeja kot obvě̌čevalnega dejavnika (Magistrsko delo), Kranj: Fakulteta za države in evropske študije.

15. Tratnik, K., 2012. Prihodnost slovenske obrambne diplomacije (Diplomsko delo). Univerza v Mariboru: Fakulteta za varnostne vede.

16. Ustava Republike Slovenije, 2013. Uradni list RS, (47). Neuradno prečiščeno besedilo. Pridobljeno 15. 1. 2016 na http://www.us-rs.si/o-sodiscu/pravna-podlaga/ustava/.

17. Vlada Republike Slovenije, 2016. Srednjeročni obrambni program Republike Slovenije 2016-2020. Pridobljeno 20. 2. 2016 na http://www.mo.gov.si/fileadmin/mo.gov.si/ pageuploads/pdf/predpisi/obramba/SOPR2016_2020.pdf.

18. Vukadinović, R., 1995. Diplomacija: strategija političnih pogajanj. Ljubljana: Arah consulting (Zbirka Preobrazbe).

19. Zupančič, M., 2010. Vojaški ataše - na razpotju med vojaško organizacijo in civilnim okoljem (Magistrsko delo). Univerza na Primorskem: Fakulteta za management. 


\section{POJAV IN KONCEPTUALIZACIJA HIBRIDNEGA VOJSKOVANJA}

\section{EMERGENCE AND CONCEPTUALISATION OF HYBRID WARFARE}

Povzetek Koncept hibridnega vojskovanja se danes pojavlja kot izziv uveljavljenim zahodnim klasifikacijam in načinom vojskovanja. Obsega metode in sredstva, ki bodo v prihodnosti verjetno del večine konfliktov. Kljub široki rabi tega termina pa hibridno vojskovanje še ni ustrezno opredeljeno. Obstajajo tudi nasprotujoča mnenja o relevantnosti in koristi tega koncepta. V prispevku so na kratko prikazane težave opredeljevanja koncepta hibridnega vojskovanja, opisani so tudi nekateri primeri konfliktov, pri katerih je tovrstno vojskovanje zelo izrazito. Povzete so temeljne splošne lastnosti hibridnega vojskovanja, v zadnjem poglavju pa so prikazane glavne težave in možnosti zoperstavljanja nasprotniku, ki uporablja takšne oblike vojskovanja.

Ključne Hibridno vojskovanje, mednarodno varnostno okolje, Nato, sodobni konflikti, besede Ukrajina, Islamska država.

Abstract Nowadays, the concept of hybrid warfare presents a substantial challenge to recognised western classifications and forms of warfare. It comprises methods and means which will in the future probably be used in the majority of conflicts. Despite a broad use of the term, hybrid warfare is not yet appropriately conceptualised. In addition, there are different views about the relevance and benefit of the hybrid warfare concept. The article provides a short overview of problems connected with defining the concept of hybrid warfare and describes some conflicts in which such mode of warfare is typically used. It also summarizes general characteristics of hybrid warfare. The last chapter of the article deals with the basic problems and possibilities of countering an adversary using such forms of warfare.

Key words Hybrid warfare, international security environment, NATO, contemporary conflicts, Ukraine, Islamic State. 
Uvod Skozi zgodovino lahko spremljamo stalno spreminjanje sredstev in oblik vojskovanja, ki je posledica tehnoloških in družbenih sprememb. Pri razumevanju značilnosti, ki so bistvene za določeno obdobje ali način vojskovanja si po navadi na abstraktnejši ravni pomagamo s koncepti vojskovanja. Od sredine prejšnjega desetletja, še bolj pa po dogodkih leta 2014, vse pogosteje srečamo koncept »hibridnih groženj« in »hibridnega vojskovanja« (angl. hybrid threats, hybrid warfare). Najbrž ne bi pretiravali, če bi rekli, da gre, vsaj v zahodni vojaški misli, za presenečenje in odklon od pričakovanega razvoja vojskovanja. Zadnja desetletja je zahodno vojaško misel zaznamovala predvsem predstava o revoluciji v vojaških zadevah (angl. Revolutin in Military Affairs - RMA). Ta izhaja iz domene, da bo zahodni način vojskovanja temeljil na visoki tehnologiji, pri kateri bo omogočena povezava med preciznim orožjem in informacijsko tehnologijo, ki bo zagotovila vojaško premoč. ${ }^{1}$ Vendar se takšna pričakovanja niso popolnoma uresničila. Kot ugotavlja Ferris (2010, str. 254), so bila pričakovanja glede RMA previsoka, dogodki v Iraku, Afganistanu in Libanonu pa so jih diskreditirali. V primeru ZDA se je pokazalo, da je RMA povečala njihovo moč, ni pa zmanjšala njihovih šibkosti. V tem smislu, tako meni Ferris, »revolucijo v vojaških zadevah« spremlja tudi »protirevolucija«. Podobno trdi tudi Lonsdale (2008, str. 54-7), da so se pričakovanja glede koristi RMA oziroma vojaške transformacije pokazala kot preveč optimistična. Vojskovanje, temelječe na teh dosežkih, se je izkazalo za neučinkovito, ko se je bilo treba spoprijeti z neregularnimi oblikami vojskovanja oziroma z asimetričnimi strategijami, ki so jih razvili nasprotniki zahoda. Po vojni v Iraku leta 2003 so se zamisli RMA pokazale kot neustrezne glede na kompleksni značaj vojne.

V tem kontekstu je mogoče razumeti tudi razvoj oblik vojskovanja, ki ga označujemo kot hibridno vojskovanje in je danes eden temeljnih izzivov za zahodne koncepte vojskovanja. Vendar do zdaj pojem hibridnega vojskovanja ni jasno opredeljen; ni enotnega mnenja o tem, ali gre v resnici za novo obliko vojskovanja; obstajajo pa tudi različna mnenja o uporabnosti oziroma analitični relevantnosti tega koncepta. Ob sicer pomanjkljivi konceptualizaciji in nejasnostih glede teoretične relevantnosti koncepta hibridnega vojskovanja je veliko pozornosti namenjeno preučevanju njegovih konkretnih oblik. Empirično podlago tovrstnega preučevanja predstavljajo predvsem vojaške operacije v Libanonu leta 2006, konflikt v Ukrajini ter delovanje Islamske države.

\footnotetext{
Parker navaja, da se »zahodni način vojskovanja tradicionalno opira na tehnološko premoč, ki je pogosto nadomestitev za številčno premoč nasprotnika. Poleg tega so sestavni deli tega načina vojskovanja še disciplina, agresivna vojaška tradicija, sposobnost prilaganja na spremembe in sposobnost zagotavljanja finančnih sredstev za uvajanje sprememb (Speller in Tuck, 2008, str. 6).
} 


\section{PROBLEMI OPREDELJEVANJA KONCEPTA HIBRIDNEGA VOJSKOVANJA}

Uporaba izraza hibridno vojskovanje je sledila uveljavitvi izraza hibridne grožnje, ki se pojavi v začetku prejšnjega desetletja v Korpusu marincev ZDA. Tako so želeli označiti delovanje nasprotnika, ki uporablja kombinacijo različnih sredstev in dejavnosti. Koncept hibridnih groženj Fleming (2011, str. 2-4) označi kot poglede vojske ZDA na to, kako reševati kompleksno okolje operacij, v katerih nasprotnik uporablja neomejeno veščino operacij, pri čemer za dosego ciljev povezuje vsa razpoložljiva orodja. Meni, da predstavlja hibridno grožnjo nasprotnik, lahko je država ali pa nedržavni akter, ki za doseganje svojih ciljev na prilagodljiv način in hitro z združevanjem ustvarja različne in dinamične kombinacije konvencionalnih, neregularnih, terorističnih in kriminalnih zmogljivosti kot tudi nevojaških sredstev. Ameriški avtorji hibridno vojskovanje praviloma obravnavajo kot obliko vojskovanja šibkejšega proti močnejšemu nasprotniku. Vendar praksa kaže, da to ni vedno tako.

Danes ni soglasja o tem, koliko predstavlja hibridno vojskovanje novo obliko vojskovanja, saj pravzaprav združuje uporabo različnih oblik, ki so bile poznane že v preteklosti. Pri razumevanju hibridnega vojskovanja se pogosto sklicujejo na razprave Franka Hoffmana (2009), enega najbolj prominentnih preučevalcev tega koncepta, ki meni, da hibridne vojne niso nove, temveč so drugačne. Opozarja, da je v vojnah skoraj vedno šlo za združevanje različnih oblik vojskovanja. V preteklosti je hkratna uporaba regularnega in neregularnega vojskovanja ${ }^{2}$ dobila ime sestavljeno (angl. compound) vojskovanje. Vendar opozarja, da je treba hibridno vojskovanje razumeti kot kompleksnejšo obliko vojskovanja. Gre za združitev »celotnega spektra oblik vojskovanja, vključno s konvencionalnimi zmogljivostmi, uporabo neregularnih taktik in formacij, terorističnih dejanj, ki obsegajo nediskriminatorno nasilje in prisilo ter kriminalne dejavnosti«. Vse te dejavnosti so usmerjene in usklajene za doseganje sinergijskih učinkov v fizičnih in psiholoških razsežnostih konflikta (Hoffman, str. 36). Hoffman hibridno vojskovanje razume predvsem kot zlitje vseh oblik delovanja v celoto. Pri tem pa so razlike med posameznimi oblikami vojskovanja vedno bolj zabrisane. Opozarja tudi na verjetnost, da bo tovrstno vojskovanje glavna poteza prihodnjega varnostnega okolja.

Jacobs in Lasconjarias (2015) opozarjata, da je opredeljevanje hibridnega vojskovanja težavno in da se termin uporablja arbitrarno (odvisno od posamezne presoje) ter brez vsake jasne konceptualizacije. Pogosto odraža brisanje razlik med vojaško in civilno sfero. Posebnosti hibridnega vojskovanja poskušata razložiti z oporo na tri elemente: instrumenti, akterji in prostor.

\footnotetext{
Neregularno vojskovanje je v zahodni vojaški terminologiji pogosto uporabljen pojem, ki pa ga različno opredeljujejo. Ena od definicij pove, da je: »/.../neregularno vojskovanje nasilje, ki ga pod-državni (sub-state) akterji ali skupine znotraj države uporabljajo za politične namene doseganja oblasti, nadzora in legitimnosti, pri tem pa zaradi svoje šibkosti v zmogljivostih uporabljajo neortodoksne ali nekonvencionalne pristope k bojevanju«. Med neregularno vojskovanje se uvrščajo državni udar, terorizem, revolucija, vstajništvo in državljanska vojna (Kiras, 2008, str. 232-234).
} 
Ena ključnih značilnosti hibridnega vojskovanja je kombinacija različnih instrumentov (vojaške sile, tehnologije, kriminalne dejavnosti, terorizma, ekonomskega pritiska, humanitarnih in religijskih sredstev, obveščevalne dejavnosti, sabotaže in dezinformiranja), ki se uporabljajo »)usklajeno kot del fleksibilne strategije $\ll$.

Druga posebnost hibridnega vojskovanja je vrsta akterjev, ki ga izvajajo. Akterji so lahko nedržavni akterji (milice, transnacionalne kriminalne skupine ali teroristične mreže), ki jih pogosto lahko podpira ena ali več držav. Hibridno vojskovanje pa lahko uporablja tudi država v izvajanju prikritega delovanja.

Prostor, na katerem potekajo različne oblike hibridnega vojskovanja, ne obsega samo fizičnega bojišča (kopnega, morja in zračnega prostora), temveč tudi uporabo tradicionalnih in novih medijskih sredstev, zato da bi akterji lahko posredovali razlage skladno s svojimi interesi in cilji. Namen je, osamiti in oslabiti nasprotnika z vsestranskim napadom na njegovo legitimnost oziroma doseči razkroj legitimnosti.

Na podlagi teh elementov omenjena avtorja opredelita hibridno vojskovanje kot: »/.../ obliko nasilnega konflikta, v katerega so hkrati vpleteni država in nedržavni akterji, z uporabo konvencionalnih in nekonvencionalnih sredstev bojevanja, ki ni omejen na bojišče ali konkretno fizično ozemlje« (Jacobs in Lasconjarias, 2015, str. 3).

Ne moremo pa tudi mimo pogledov na hibridno vojskovanje, ki se osredotočajo na pomen civilnega prebivalstva $\mathrm{v}$ tem vojskovanju. McCuen (2008) hibridno vojno obravnava kot kombinacijo simetrične in asimetrične vojne, v kateri se izvajajo tradicionalne vojaške operacije proti nasprotnikovim vojaškim silam in tarčam, ob tem pa si je treba odločno prizadevati za nadzor prebivalstva na vojnem območju. Hibridno vojskovanje ima tako svojo fizično dimenzijo, izraženo v bojevanju proti oboroženemu nasprotniku, in konceptualno dimenzijo, ki obsega prizadevanje za nadzor ter podporo prebivalstva na vojskovališču in tudi za podporo domače javnosti v vojskujoči državi ter podporo v mednarodni skupnosti. »Na bojiščih hibridnih vojn poteka boj za legitimnost in za podporo ljudi« (McCuen, 2008, str. 108). Podobno tudi Hoffman (2009, str. 36) opozarja, da gre pri aktivnostih, ki jih obsega hibridno vojskovanje za usmerjanje in koordinacijo na operativni in taktični ravni s ciljem doseganja sinergijskih učinkov v fizični in psihološki dimenziji vojskovanja.

V Sloveniji do zdaj ni bilo veliko razprav o konceptu hibridnega bojevanja. Eden redkih objavljenih prispevkov (Škerbinc, 2015) precej poglobljeno prikaže razvoj koncepta in njegove vsebinske prvine. Opozori, da hibridno vojskovanje ni nov pojav in opozori na podobne koncepte, ki so se pri nas uveljavili že v preteklosti, kot so npr. strategija posrednega nastopanja, specialna vojna, konflikt nizke intenzivnosti itn. Meni, da so današnji pogledi avtorjev na pojem hibridnega vojskovanja neenotni in 
predstavi danes najbolj uveljavljene definicije. Opozori tudi, da je bolj kot ukvarjanje s poimenovanjem tega pojava pomembno, da to obliko vojskovanja razumemo.

Medtem ko danes hibridno vojskovanje vse pogosteje obravnavajo kot obliko prihodnjih konfliktov in zato poudarjajo pomen razumevanja tovrstnega vojskovanja, pa med strokovnjaki zasledimo tudi dvome o smiselnosti takšnega pristopa. Najprej spoznamo prepričanja, da takšno vojskovanje pravzaprav ni nič novega. Strinjamo se lahko, da ima vojskovanje evolucijski značaj. Kot opozarjata Speller in Tuck (2008, str. 9), so številne njegove značilnosti rezultat postopnega razvoja konceptov in struktur iz preteklih obdobij. Skladno s takšnim razumevanjem je v razvoju vojskovanja bolj malo revolucionarnih preskokov in tudi razvoj hibridnega vojskovanja lahko razumemo kot postopni razvoj že poznanih oblik v novih razmerah.

Hibridno vojskovanje bi težko obravnavali kot nov koncept, meni Parameswaran (2015); podobne oblike oziroma kombinacije metod vojskovanja obstajajo že stoletja. Podobno meni Huber, da koncept hibridnega vojskovanja ni nov in da gre preprosto za obliko vojskovanja, ki jo poimenujemo vstajništvo (angl. insurgency) (Fleming, str. 15). Zavračanje koncepta hibridnega vojskovanja izhaja tudi iz prepričanja, da je ta ideja preveč abstraktna (Fleming, 2011, str. 3); ali da je neuporabna, kot meni Kiras (2008, str. 229), ki pove, da pojem »hibridno bojevanje opisuje vse, vendar ne pojasni ničesar«. Strinjamo se lahko s prepričanjem, da zamisel uporabe različnih in tudi nekonvencionalnih sredstev v konfliktu ni nova. Na nek način je stara toliko, kot je staro vojskovanje. ${ }^{3}$ Vendar pa moramo, kot opozarjata Jacobs in Lasconjaris (2015, str. 1), danes hibridno vojskovanje razumeti kot izkoriščanje »starih orodij na nov način«.

Zadržki glede uporabnosti koncepta hibridnega vojskovanja izhajajo tudi iz popolnoma pragmatičnih razlogov. Zasledimo lahko na primer očitke, ki prihajajo iz baltskih držav, da je ta koncept predvsem način, kako bi se Nato izognil odločnejši akciji proti Rusiji, še posebno zato, ker Nato nima delujočega koncepta za reševanje tovrstnih groženj (Schadlow, 2015). S tem se mogoče ne moremo popolnoma strinjati. Vendar pa bi se Nato lahko znašel v precej kočljivi situaciji, če bi bili proti kateri od zaveznic uporabljeni načini vojskovanja, podobni, kot jih je uporabila Rusija proti Ukrajini.

V razpravi ne moremo spregledati še razmerja hibridnega vojskovanja do drugega, $\mathrm{v}$ sodobnosti prav tako pogosto uporabljenega koncepta, to je asimetrično vojskovanje. Ob že omenjeni nezadostni konceptualizaciji prvega termina je natančna razmejitev še težja. Poskušajmo pogledati nekaj podobnosti in razlik. Oba termina opisujeta obliko vojskovanja, ki se razlikuje od konvencionalnega razumevanja vojskovanja. Nekateri avtorji asimetrično vojskovanje povezujejo predvsem z aktivnostmi nedržavnih akterjev proti močnejšemu nasprotniku (Palmer, 2015, str. 1). Termin

Fleming (2011, str. 9) meni, da je mogoče načela in poglede, ki sta jih razvila že Sun Cu Wu in Clausewitz, razumeti kot intelektualne temelje današnjega razumevanja hibridnega vojskovanja. 
asimetričnost kaže na različnost strani v konfliktu. Vendar pri tem ne gre samo za razliko v vojaški moči - te razlike so skoraj v vsakem konfliktu. Gre za bolj temeljne razlike v pristopih. Metz asimetrično vojskovanje opredeljuje kot »delovanje, organiziranje in razmišljanje, ki je drugačno od nasprotnikovega in ima za cilj maksimizirati relativno moč, izkoristiti nasprotnikovo šibkost in si pridobiti večjo svobodo delovanja« (Lonsdale, str. 55). Podobno pojem asimetrije razumejo tudi Svete, Guštin in Prebilič (2010), ki opozarjajo, da se ta ne nanaša le na merljive in materialistične kazalce moči, temveč tudi na neprimerljivost sodelujočih $\mathrm{v}$ konfliktih, ki se kaže pri uporabi sredstev in metod. Izraz asimetrično vojskovanje kaže predvsem na različnost v vojaških pristopih. Izraz hibridno vojskovanje pa je večinoma usmerjeno $\mathrm{v}$ opis kompleksnosti vojskovanja, pri čemer je poudarjena kombinacija različnih nevojaških in vojaških metod ter sredstev. Asimetričnost je pri tem ena od značilnosti hibridnega vojskovanja. Podobno razumevanje srečamo tudi pri več avtorjih, ki hibridno vojskovanje opisujejo kot kombinacijo asimetričnih in drugih oblik vojskovanja (McCuen, 2008; Fleming, 2011, str. 36).

Kljub vsem kontroverznostim, ki jih prinaša, je koncept hibridnih groženj in hibridnega vojskovanja iz vojaških vrst hitro prešel tudi v širšo uporabo in se začel uveljavljati v dokumentih ministrstev za obrambo in drugih varnostnih agencijah, najprej v ZDA, ter postopoma prešel tudi v druge zahodne države. Udomači se tudi v terminologiji v Natu. Še posebno aktualna postane obravnava hibridnega vojskovanja po začetku ukrajinske krize leta 2014, ki je spremenila dojemanje varnosti v Evropi s spoznanjem, da tudi vojaške grožnje Natu niso tako oddaljene, kot smo mislili v zadnjih petindvajsetih letih. ${ }^{4}$ Danes se je ta koncept dobro že uveljavil v vojaških vrstah (v različnih doktrinah in navodilih), v političnih dokumentih in razpravah ter tudi med teoretiki na področju vojskovanja.

\section{PRIMERI UPORABE HIBRIDNEGA VOJSKOVANJA}

Preučevanje hibridnega vojskovanja je danes postavljeno pred problem razumevanja na splošni ravni oziroma nezadostne konceptualizacije. Jacobs in Lasconjarias (2015, str. 3) temu konceptu ne pripisujeta značaja teoretičnega scenarija in poudarjata, da temelji na empiričnem opazovanju vojskovanja po koncu hladne vojne. Ob tem, ko ne moremo govoriti o teoretično jasno opredeljeni kategoriji vojskovanja, smo po drugi strani priča intenzivnemu preučevanju konfliktov, v katerih srečamo tovrstne oblike vojskovanja. Preučevanje hibridnega vojskovanja dobi zagon po operaciji izraelske vojske v Libanonu leta 2006, v kateri je naletela na organiziran in precej

\footnotetext{
4 Po letu 1989 je strategija Nata temeljila na prepričanjih, da je evro-atlantska skupnost stabilna; Natov sistem kolektivne obrambe ni resno ogrožen; Natove najbolj verjetne vojaške misije bodo t. $i$. out-of area operacije; širitev atlantske skupnosti bo vodila do enotne in miroljubne Evrope; Rusija je ali bo skoraj postala strateški partner. Vse te premise so z dogodki na vzhodu Evrope postale vprašljive (Kroenig, 2015, str. 49).
} 
učinkovit odpor gibanja Hezbolah. ${ }^{5}$ Za boljše razumevanje bomo v tem poglavju na kratko prikazali temeljne poteze dveh aktualnih konfliktov, ki jima največkrat pripisujejo značaj »hibridnih vojn«: prikrito delovanje Rusije proti Ukrajini od leta 2014 in delovanje »Islamske države« na ozemlju Iraka in Sirije.

\section{Ukrajina}

V začetku leta 2014 se je že dlje časa tleči konflikt med Rusijo in Ukrajino spreobrnil v nasilno fazo, katere posledici sta priključitev Krima Ruski Federaciji in oborožen konflikt v ukrajinskih regijah Donetsk in Lugansk. Delovanje Rusije v tem konfliktu obravnavajo kot izrazit primer izvajanja hibridnega vojskovanja, z vojaškega vidika pa kot implementacijo dalj časa razvijajoče se »Gerasimove doktrine«. Geopolitični cilj ruske strategije je destabilizacija Ukrajine, nasprotovanje njeni proevropski politiki in preprečitev tesnejšega povezovanja Ukrajine z EU in Natom. Rusija namreč širitev EU in Nata vidi kot proces, ki je v nasprotju z njenimi interesi, hkrati pa tudi nasprotuje vlogi ZDA v mednarodni politiki. ${ }^{6}$ Aktivnosti Rusije razumejo kot začetek eskalacije nedeklariranega bojevanja proti novi vladi v Kijevu in proti prizadevanjem »Zahoda«, da bi Ukrajino iztrgal iz ruskega vplivnega območja (Johnson, 2015, str. 8). Notranjepolitični razlog za takšno rusko politiko je predvsem bojazen, da bi se upor proti režimu, po zgledu nemirov v Ukrajini in drugih »barvnih revolucij«, pojavil tudi v Rusiji in ogrozil obstoječi režim. ${ }^{7}$

Ruske aktivnosti so sledile odstavitvi prorusko usmerjenega ukrajinskega predsednika Janukoviča 22. februarja 2014 in oblikovanju začasne vlade, potem ko je ta novembra 2013 zavrnil podpis asociacijskega sporazuma z EU. Začasno vlado je Rusija razumela za nelegitimno, po njeni vzpostavitvi je začela s koncentracijo vojaških sil na vzhodni meji Ukrajine in s prikritimi aktivnostmi in delovanjem pripadnikov svoje vojske na Krimu. Te je uporabljala predvsem kot sredstvo psihološkega vojskovanja. ${ }^{8} \mathrm{Na}$ Krimu, kjer sicer prevladuje rusko prebivalstvo, se je začela kampanja proruskega gibanja, ki ga je podpirala Rusija, in sicer za odcepitev Krima. ${ }^{9}$ V obdobju krize na Krimu je Rusija v svojem srednjem in zahodnem vojaškem območju začela izvajati obsežne vojaške vaje, v katerih je sodelovalo do

\footnotetext{
Učinkovit odpor Hezbolaha ob izraelski akciji je pomenil strateško presenečenje in poleg neposrednih vojaških posledic dosegel tudi znatni psihološki učinek. Danes ga analitiki pogosto obravnavajo kot primer za analizo težav, s katerimi se bodo sodobne zahodne vojske verjetno srečevale v prihodnjih konfliktih. Kot meni Piotrowski (2015), je lahko delovanje Hezbolaha verjetno najboljši indikator glede razvoja konfliktov in vojskovanja $v$ prihodnje in je zelo relevantno za razprave glede prilagajanja Nata novim grožnjam in hibridnemu vojskovanju.

Več o geopolitičnih dimenzijah tega konflikta v Speck, 2014.

Lidley-French (2015, str. 6) meni, da je Rusija danes revizionistična sila, ki se želi znebiti občutka ponižanja in si želi povečati svojo veljavo z vzpostavitvijo novega vplivnega območja; vendar pa uporablja hibridno vojskovanje predvsem za ohranitev svojega obstoječega režima v razmerah, ko mora rešiti znatne ekonomske in socialne probleme.

${ }^{8}$ Za pripadnike ruske vojske se je v medijih uveljavil izraz »mali zeleni možje« (little green men). Ti so se pojavljali v vojaških uniformah brez oznak, Rusija je njihovo pripadnost zanikala s trditvami, da gre za samoorganizirane lokalne obrambne sile.

9 Konflikti glede statusa Krima med lokalnimi krimskimi oblastmi in vlado v Kijevu so potekali že v 90-ih letih. Poleg tega je na Krimu ruska črnomorska flota s 25.000 pripadniki, sporazum o baziranju med Ukrajino in Rusijo pa je veljal do leta 2042.
} 
50.000 pripadnikov, ${ }^{10}$ hkrati pa je opozarjala na pripravljenost svojih jedrskih sil, s čimer je želela odvrniti vsako zunanje vpletanje v svoje operacije proti Ukrajini. V teh razmerah je krimski parlament $\mathrm{v}$ začetku marca izglasoval odločitev o priključitvi $\mathrm{k}$ Rusiji, o čemer je bil 16. marca organiziran referendum, ki je s 97-odstotno večino potrdil to odločitev.

Sočasno je prišlo do intenziviranja proruskih gibanj in separatističnih teženj $\mathrm{v}$ Donbasu na vzhodu Ukrajine. ${ }^{11}$ Rusija je izkoristila svoje manjšine v Ukrajini kot notranjo opozicijo in podpirala njihovo nasprotovanje oblastem. Gibanja, ki jih je podpirala Rusija, so postavljala različne zahteve, od povečanja avtonomije, izboljšanja socialnih pogojev pa vse do odcepitve in priključitev k Rusiji. V začetku aprila so uporniki razglasili samostojni republiki Donetsk in Lugansk, 11. maja pa so organizirali referendum o neodvisnosti, za katerega je v Donetsku glasovalo 89 in v Lugansku 96 odstotkov udeležencev. 18. maja sta se obe republiki združili v t. i. Novorusijo. Podpora Rusije tem procesom je bila nenehno intenzivna. ${ }^{12}$ V sredini aprila je Ukrajina začela z obsežnejšimi vojaškimi in policijskimi akcijami za ponovno vzpostavitev nadzora nad omenjenimi regijami. Hkrati pa so se v Ženevi začela mednarodna pogajanja o ukrajinski krizi. Do zdaj je bilo doseženih nekaj dogovorov o premirju, ki pa niso bili spoštovani. Spopadi med vladnimi silami in uporniškimi gibanji so potekali vse do konca leta in se nadaljevali tudi v letu 2015. Samo v letu 2014 so spopadi, po podatkih ZN, terjali najmanj 4700 smrtnih žrtev, 10.300 ranjenih na obeh straneh, približno pol milijona prebivalcev je zbežalo $\mathrm{v}$ tujino, okoli 600.000 pa je ubežnikov znotraj Ukrajine (Conflictbarometer, 2014, str. 42). V sedanji situaciji ni videti rešitve konflikta, saj vse kaže na dolgoročno nestabilnost, zastoj v približevanju Ukrajine EU in Natu ter dolgoročno konfliktnost z Rusijo.

V Ukrajini je Rusija svoje politične cilje dosegla brez odkritega vpletanja v vojno, z uporabo prikritega vojaškega delovanja, povezanega z nevojaškimi metodami, pri čemer je imelo pomembno vlogo informacijsko-propagandno delovanje. ${ }^{13}$ Uspešnost uporabljenih metod je v znatni meri povezana z značilnostmi Ukrajine, ki je že pred tem konfliktom kazala lastnosti »šibke države«, s številnimi notranjimi nasprotji, ekonomskimi problemi, slabim upravljanjem idr. Vsega tega Rusiji ni bilo težko izrabiti za slabitev Ukrajine. ${ }^{14}$ Ruske aktivnosti so ves čas vključevale tudi

\footnotetext{
${ }^{10}$ Ruska stran je zanikala kakršno koli povezavo teh vaj z dogodki v Ukrajini. Pojasnjevali so jih kot nenapovedano preverjanje vojaške pripravljenosti ali kot načrtovano bojno usposabljanje.

II Donbas, v katerem prevladujejo rusko govoreči državljani, obsega regije Donestsk, Harkov in Lugansk.

12 Ukrajina je Rusijo obtoževala za načrtovanje invazije, za usklajevanje zasedbe državnih ustanov na vzhodu Ukrajine, za pošiljanje pripadnikov ruske vojske na njeno ozemlje v podporo militantnim upornikom in za njihovo oskrbovanje z oborožitvijo in opremo. Rusija je vse obtožbe vztrajno zanikala (Conflicbarometer, 2014, str. 37-38)

${ }^{13}$ Reisinger in Golts (2014, str. 3) ugotavljata, da je v tem primeru Moskva uporablja predvsem specialne sile in svojo »mehko moč«, kot sta propaganda in tehnična pomoč.

${ }_{14}$ Tehnike hibridnega vojskovanja omogočajo optimalno izkoriščanje nasprotnikovih ranljivosti. Ukrajina je bila pod predsednikom Janukovičem krhka, razdeljena in skorumpirana ter v celoti slabo vodena država (Reisinger in Golts, 2014, str. 8).
} 
usmerjeno in sistematično dezinformiranje, kot je na primer označevanje ukrajinskih oblasti in njihovih podpornikov kot »fašističnih«, označevanje ukrajinskih ukrepov proti separatistom kot »vojno proti svojemu narodu«, poudarjanje humanitarnih posledic operacij ukrajinskih varnostnih sil proti separatistom in zahteve po omogočanju humanitarne pomoči. Netenje upora ruskih manjšin v Ukrajini pa je Rusija prikazovala kot »zaščito Rusov v tujini«. Vse to je potekalo z načrtno uporabo medijev z mednarodnim dosegom, kot na primer televizijskega kanala Russia Today.

Uspeh ruskega vojskovanja v Ukrajini je tudi posledica neustreznega odziva in slabe pripravljenosti ukrajinskih vojaških ter varnostnih sil. Analitiki na primer kot napako navajajo dejstvo, da je Ukrajina namesto enot za posebno delovanje proti upornikom uporabila enote redne vojske, večinoma sestavljene iz nabornikov in slabo izurjenih rezervistov. Te pa niso bile kos bojevanju v urbanem okolju proti upornikom, ki so delovali z oporo na civilno prebivalstvo. V splošnem je ukrajinska vojska $\mathrm{V}$ zadnjih letih trpela za veliko slabostmi, ki jim je lahko izpostavljena vojska v državi z notranjimi problemi. Znatne pomanjkljivosti vojske so na področju financiranja, kadrov, izurjenosti in logistike. ${ }^{15}$

Rusija je za doseganje svojih ciljev v Ukrajini uporabila dobro usklajeno kombinacijo sredstev in oblik vojskovanja, ki obsega uporabo opozicije oziroma manjšin za notranjo destabilizacijo države; spodbujanje nezadovoljstva in prikrito ter odkrito podporo proruskim gibanjem; intenzivno informacijsko in medijsko delovanje; koncentracijo vojaških sil $\mathrm{z}$ namenom zastraševanja; prikrito vojaško podporo proruskim gibanjem ter zastraševanje s pripravljenostjo jedrskih sil z namenom odvračanja morebitnega posredovanja Zahoda. ${ }^{16}$ Rusija je pri tem znala spretno izkoristiti družbene, politične in vojaške slabosti Ukrajine, delovanje pa je temeljilo na strategiji, ki jo je razvijala že dlje časa.

Strategijo, uporabljeno v Ukrajini, večina analitikov razume kot implementacijo ruskih doktrinarnih izhodišč, ki so bila razvita $v$ zadnjih letih, posebno pa po ruskem posegu v Gruziji leta 2008, in na podlagi preučevanja značilnosti konfliktov v t. i. arabski pomladi. ${ }^{17} \mathrm{Za}$ ta izhodišča se je uveljavil tudi izraz »Gerasimova doktrina« ${ }^{18}$ Bistvo doktrine je »integrirana uporaba« vojaških in nevojaških ukrepov (Rühle in Grubliauskas, 2015, str. 2). Temeljne značilnosti te doktrine so predstavljene v tabeli 1.

\footnotetext{
${ }^{15}$ Ukrajinska vojska šteje 41.000 pripadnikov kopenskih sil, od katerih jih je v resnici samo 6000 dosegalo stanje ustrezne bojne pripravljenosti. Glede opreme, logistike in zaščite je ukrajinska vojska uspela pokrivati samo 10 odstotkov potreb, velik del teh potreb so pokrivali s prostovoljnimi donacijami ali tako, da so si pripadniki oborožitev in opremo nabavljali sami (podrobneje glej Reisinger in Goltz, 2014, str. 8-10).

${ }^{16}$ Ruska strategija je kombinacija hibridnega vojskovanja in grožnje z uporabo jedrskega orožja, ki naj bi Nato odvračala od tega, da bi posegal v konflikt med Rusijo in katero koli državo (Kroenig, 2015, str. 53-54).

${ }^{17}$ Ta dogajanja v Rusiji vidijo kot posledico delovanja »Zahoda« s ciljem rušenja obstoječih režimov v arabskih državah.

18 Poimenovana po načelniku generalštaba generalu Valeriju Gerasimovu.
} 


\begin{tabular}{|c|c|}
\hline \multirow{6}{*}{$\begin{array}{r}\text { Tabela 1: } \\
\text { Značilnosti } \\
\text { Jerasimove« } \\
\text { doktrine }\end{array}$} & Prikriti in neposredni značaj večine izvajanih aktivnosti \\
\hline & $\begin{array}{l}\text { Odločilna vloga aktivnosti v informacijskem prostoru (informacijska kampanja zavzema osrednji pomen in } \\
\text { skladno s tem je treba načrtovati vse druge aktivnosti) }\end{array}$ \\
\hline & $\begin{array}{l}\text { Prikrivanje (rus. maskirovka) resničnih ciljev aktivnosti (uradno proglašeni cilji imajo namen prikriti resnične } \\
\text { cilje) }\end{array}$ \\
\hline & Povečana vloga sodelovanja med resorji in organizacijami \\
\hline & Delovanje sodelujočih vodi enoten organ vodenja, v katerega so vključeni predstavniki vladnih struktur \\
\hline & Vir: Johnson, 2015, str. 8. \\
\hline
\end{tabular}

Pomemben sestavni del učinkovitosti ruskega delovanja v Ukrajini je centralizirano vodenje delovanja. To omogoča centralizacija politične oblasti, ki v Rusiji poteka od prihoda Vladimirja Putina na oblast. Skladno s tem je bila izvedena tudi centralizacija državnih struktur na področju varnosti in obrambnih zadev. Johnson (2015, str. 10) razlaga, da je predsednik Putin v zadnjih dveh letih centraliziral in prestrukturiral procese določanja, okrepil koordinacijo med vladnimi telesi na področju obrambe ter posodobil poveljevanje in nadzor tako temeljito, da to spominja že na prakso vodenja v II. svetovni vojni.

\section{Islamska država}

Islamska država (Islamic State - IS) je sunitsko, militantno ekstremistično gibanje, prvotno imenovano ISIS, ${ }^{19}$ ki si je z vojaškimi aktivnostmi zagotovilo teritorialno bazo za svoje delovanje (Irak in Sirija), njegov vpliv pa v različnih oblikah delovanja sega mnogo širše. Korenine gibanja segajo v leto 2000, pozneje pa so njegovi pripadniki prihajali iz vrst častnikov razpuščene vojske Sadama Huseina, sunitskih plemen, čečenskih borcev in iz džihadističnih gibanj po svetu. IS deluje v razmerah nedelovanja ali razpada držav - Iraka in Sirije. Vojaški uspeh IS, menita Fromson in Simon (2015, str. 17-19), je treba pripisati dejstvu, da je IS uspela mobilizirati Sunite na podlagi njihovega nezadovoljstva z Asadovim režimom v Siriji in z iraško vlado, v kateri prevladujejo šiiti. ISIS je v letih 2013 in 2014 uspel zavzeti znatne dele ozemlja teh dveh držav. 29. junija 2014 je proglasil kalifat in se preimenoval v Islamsko državo - IS. Leta 2014 je IS uspelo osvojiti nekaj pomembnih mest in gospodarskih regij v obeh državah; junija 2014 na primer Mosul, drugo največje iraško mesto, od koder so se bili prisiljeni umakniti 18. avgusta. V določenih obdobjih je IS nadzorovala blizu 50 odstotkov sirskega ozemlja. ${ }^{20}$

\footnotetext{
19 Islamic State of Iraq and Syria.

${ }^{20}$ IS naj bi na območju Iraka in Sirije nadzorovala ozemlje s približno 7-8 milijoni prebivalcev (Fromson in Simon, 2015, str. 9)
} 
Ocenjujejo, da je IS v letu 2014 štela približno 30.000 pripadnikov. Bojna zmogljivost je sestavni del, ki podpira njene druge aktivnosti - politične, ideološke in socialne; njen vojaški napredek pa je mogoče pojasniti s tremi elementi: številčnostjo, kakovostjo enot in agresivnostjo, menita Fromson in Simon (2015, str. 9). Vojaške enote IS ocenjujejo kot dobro vodene in visoko motivirane, polega tega imajo dober sistem za urjenje novih pripadnikov. Leta 2014 je IS, predvsem z zaplembami, pridobila znatne količine sodobne oborožitve ruskega in ameriškega porekla, s katero se je po moči lahko primerjala z nekaj iraškimi divizijami (prav tam, str. 10). ${ }^{21}$ Vojaško delovanje IS temelji predvsem na uporabi hitro premičnih in dobro oboroženih enot na terenskih vozilih, ob tem pa uporabljajo še artilerijsko obstreljevanje, samomorilske napade in celo kemična sredstva. Razpolagajo z dobro obveščevalno podpro, ki se opira na lokalne podpornike in informatorje.

IS deluje $\mathrm{z}$ vojaškimi sredstvi, dopolnjenimi z brutalnostjo in propagandnopsihološkim delovanjem. Značilnosti vojskovanja IS so ekstremizem, netolerantnost do drugačnih in uporaba izrazito nasilnih metod, kot so poboji in izgoni civilistov, usmrtitve ujetih nasprotnikov in talcev, izvajanje terorističnih napadov zunaj območja, na katerem deluje idr. IS intenzivno izvaja psihološko-propagandno delovanje, pri čemer se opira na sodobne tehnologije, predvsem medmrežje. ${ }^{22}$ IS širi svoj vpliv tudi na območje Magreba in na zahod, kjer pridobiva somišljenika in rekrutira svoje pripadnike. ${ }^{23}$ IS se je pridružilo več tisoč prostovoljcev in drugih držav, med njimi jih po nekaterih ocenah 1500 prihaja iz Francije in okoli 700 iz Velike Britanije.

Delovanje IS je izrazit primer delovanja nedržavnih akterjev na območjih, na katerih ni učinkovitih državnih struktur. Kot so zapisali v poročilu iz Natove konference, posvečene hibridnemu vojskovanju, je ISIL akter, ki združuje lastnosti »teroristične skupine, vlade, kriminalne mafije, humanitarne organizacije, organizacije za pridobivanje kadrov in redne vojske« (Lindley-French, 2015, str. 6). Hkrati pa učinkovito uporablja kombinacijo različnih oblik vojskovanja, kot so konvencionalne vojaške operacije, terorizem, organiziran kriminal, kampanje prek družbenih medijev in kibernetsko vojskovanje.

\section{TEMELNE ZNAČILNOSTI HIBRIDNEGA VOJSKOVANJA}

Navedena primera hibridnega vojskovanja se zelo razlikujeta glede akterjev vojskovanja (države in nedržavni akterji), prikrivanja vpletenosti v konflikt, uporabljenih metod idr. Kljub razlikam je, že zato, ker so takšne vrste konfliktov

\footnotetext{
${ }^{21}$ Težja oborožitev obsega ruske tanke T-55 in T-72, ameriške tanke Abrams M1A1, vozila Humvee, artilerijo, vodene protitankovske rakete ter protiletalske rakete SA-7.

${ }^{22}$ Aprila 2015 je IS izvedla kibernetski napad na francosko televizijsko postajo TV5Monde, pri čemer je preprečila oddajanje na vseh enajstih programih in prevzela nadzor nad spletno stranjo postaje, na kateri je objavila svoje sporočilo. Ta televizijska mreža je za propagando IS posebno zanimiva, saj predvaja programe, ki jih spremljajo $v$ francosko govorečih delih Afrike.

${ }^{23}$ Eden od virov navaja, da objavljene propagandne vsebine IS na spletu v vsakem trenutku prebira 1400 posameznikov po svetu (Lindley-French, 2015, str. 6).
} 
vedno bolj verjetne tudi v prihodnosti, smiseln poskus opredelitve temeljnih skupnih značilnosti vojskovanja, ki ga akterji »hibridnih vojn« uporabljajo za dosego svojih političnih ciljev. Vse različice hibridnega vojskovanja predvsem odstopajo od splošno uveljavljenega razumevanja vojne. Hoffman (2014) na primer opozarja, da sedanji konflikt v Ukrajini ne ustreza zahodnim konceptom vojskovanja, pomeni izziv tem konceptom in ga ni mogoče umestiti $\mathrm{v}$ jasno opredeljene kategorije »vojne«. V določeni meri lahko najbrž to razumemo tudi kot posledico ozkosti in rigidnosti Zahodnih koncepcij vojskovanja.

Najizrazitejša značilnost hibridnega vojskovanja je usklajena uporaba različnih oblik vojskovanja. Gre za kombinacijo vseh vrst vojaškega (regularnega in neregularnega) delovanja in nevojaškega delovanja, ki je praviloma najpomembnejše. ${ }^{24} \mathrm{~V}$ ruskih doktrinarnih stališčih na primer najdemo prepričanje, da je v sodobnih konfliktih razmerje med nevojaškimi in vojaškimi sredstvi v razmerju 4 proti $1 \mathrm{v}$ korist prvih (Johnson, 2015, str. 6). V obeh primerih je pomembno informacijsko delovanje, obvladovanje kibernetičnega prostora in uporaba medijev za doseganje legitimnosti ter podpore svojim ciljem. Pomembni so tudi ekonomski vidiki vojskovanja. Pogosto so uporabljene oblike vojskovanja neskladne s pravno dovoljenimi in legitimnimi načini vojskovanja, kot so na primer terorizem in kriminalne dejavnosti. Kombinacija oblik vojskovanja seveda ni najpomembnejša novost, ki jo prinaša hibridno bojevanje. Tisto, kar je za sodobno hibridno vojskovanje posebno, je lahko, na kar opozarja Hoffman, zabrisovanje razlik med oblikami bojevanja in njihovo zlitje v celoto.

Druga značilnost hibridnega vojskovanje je prikrivanje akterjev, metod in ciljev. Sherr opozarja, da hibridno vojskovanje prikrije agresorja oziroma pravega protagonista vojne, prav tako pa tudi sredstva in cilje konflikta (Škerbinc, 2015, str. 26). V tej obliki vojskovanja, meni Thornton (2015, str. 41), se poskuša »ustvariti situacija, v kateri je nejasno, ali stanje vojne obstaja, če pa že, potem je nejasno, kdo je bojevnik in kdo ne«. V sodobnih konfliktih so udeleženci tako države kot številni drugi t. i. nedržavni akterji. Pogosto akterji ne želijo biti prepoznani kot udeleženci v konfliktu; kot na primer država, ki lahko svojo udeležbo prikriva tako, da pripadniki njenih oboroženih sil zakrijejo svojo identiteto, da izvaja vojskovanje prek posrednikov (proxies) ali prikrito zagotavlja vojaško pomoč. Še bolj kot na vojaškem področju je mogoče udeležbo v konfliktu prikrivati na drugih področij kot ekonomsko, informacijsko delovanje ipd. Akterji v takih konfliktih pogosto svoje cilje dosegajo tako, da ni jasno, kdo stoji za neko dejavnostjo. Prikrito (covert) vojaško delovanje pravzaprav ni novost, vendar intenzivna uporaba nevojaških metod še dodatno širi možnost prikritega delovanja. Tako je na primer Rusija v konfliktu z Ukrajino spretno izkoristila njeno energetsko odvisnost (Rühle in Grubliauskas, 2015) in prikrito uporabljala svoje oborožene sile, ob tem da uradno ni stran v konfliktu.

\footnotetext{
24 Thornton (2015, str. 5) takšno delovanje imenuje integracija in opozarja, da sodobne ruske »operacije« danes odražajo »integrirano uporabo vojaške sile ter političnih, ekonomskih, informacijskih in drugih nevojaških ukrepov«. Tako opuščajo preteklo doktrino, ki je temeljila na uporabi destruktivne ognjene moči.
} 
Izvajanje hibridnega vojskovanja pomeni tudi, da je vse težje razlikovati med mirom in vojno. V takšnem vojskovanju najdemo akterje in oblike delovanja, ki niso značilni za vojskovanje, prikriti značaj vojskovanja pa posledično zmanjšuje možnost zaznave, da to sploh poteka. Protagonist takšne vojne lahko svoje cilje večinoma doseže, še preden se žrtev in mednarodna javnost tega zavesta. Kot ugotavlja Sherr, je mogoče s hibridnim vojskovanjem onesposobiti državo, še preden ta zazna, da se je konflikt začel (Schadlow, 2015). Posledično so vse manj ustrezna tradicionalna razumevanja, pri katerih ločujemo med mirom in vojno. Na to na primer opozarja Johnson (2015, str. 8-10) pri analizi konflikta med Rusijo in Ukrajino, ki ga razume kot dolgotrajno prizadevanje Rusije, da Ukrajino z nevojaškimi sredstvi »preusmeri proti Vzhodu« oziroma na svoje vplivno območje; vojaško posredovanje od začetka leta 2014 pomeni samo fazo prehoda od uporabe nevojaških $\mathrm{k}$ uporabi prikritih vojaških sredstev.

Kot četrti sestavni del, značilen za hibridno vojskovanje, je mogoče obravnavati neomejeno delovanje (angl. unrestricted operational art). Tradicionalno vodenje vojaških operacij usmerjajo določeni načela, pravila in norme. Veščina izvajanja vojaških operacij, ugotavlja Fleming (2011, str. 32), zagotavlja povezanost strateških ciljev s posameznimi taktičnimi aktivnostmi, pri tem pa je delovanje omejeno $\mathrm{z}$ določenimi pravili. Hibridno vojskovanje pogosto poteka brez upoštevanja sprejetih norm. »Akterji hibridnih groženj poskušajo razviti neomejeno delovanje brez upoštevanja kognitivnih in moralnih omejitev in vojnega prava /.../« (Fleming, 2011, str. 34). Opažanja ameriškega avtorja opozarjajo na probleme, s katerimi se bodo zelo verjetno srečale vse zahodne vojske, saj so pravila in omejitve sprejete univerzalno. Uporaba določenih metod bo nedvomno pomenila izziv uveljavljenim zahodnim koncepcijam in »strateški kulturi«. Glede na prilagodljivost oblik hibridnega vojskovanja lahko v prihodnosti verjetno pričakujemo tudi spreminjanje socialno-kulturnih norm, znotraj katerih, vsaj na Zahodu, razumemo vojskovanje.

Čeprav je konceptualizacija hibridnega vojskovanja precej šibka, da je pravzaprav vse značilnosti že bilo mogoče zaslediti v preteklosti in da tudi ni enotnega mnenja o smiselnosti koncepta, lahko koncept hibridnega vojskovanja sprejmemo kot miselni okvir za razumevanje sprememb v bojevanju. Opozarja nas na to, da se sedanji in najbrž tudi prihodnji oboroženi konflikti bistveno razlikujejo od uveljavljenega razumevanja vojne. Pa tudi na to, da bodo različne »hibridne« oblike delovanja verjetno sestavni del vseh prihodnjih konfliktov. Strinjamo se lahko s prepričanji, da dosedanja uporaba hibridnih oblik vojskovanja omogoča številnim akterjem možnosti, da s preučevanjem izkušenj tovrstne metode še izpopolnijo in jih uporabijo v prihodnjih konfliktih (Military Balance, 2015, str. 6). Najbrž je tudi na splošno upravičeno pričakovanje, ki ga je McCuen (2008, str. 111) izrazil glede ameriške vojske, in sicer, da lahko ZDA pričakujejo, da bodo vodile hibridno vojno v vsakem prihodnjem posegu. 


\section{MOŽNOSTI IN PROBLEMI ZOPERSTAVLJANJA HIBRIDNEMU VOJSKOVANJU}

Spremembe v vojskovanju, ki jih obravnavamo s konceptom hibridnega vojskovanja, zahtevajo tudi razmislek o tem, kako se zoperstaviti morebitnemu akterju, ki takšno vojskovanje uporablja. S tega vidika se zdi smiseln razmislek na dveh ravneh: 1) na ravni organizacije in delovanja nacionalnih varnostnih in obrambnih struktur; 2) na ravni delovanja Nata v zagotavljanju varnosti svojih članic. Oba sklopa vprašanj sta tudi medsebojno povezana. $\mathrm{Na}$ obeh ravneh lahko zasledimo, da so razprave o hibridnih oblikah vojskovanja vedno intenzivnejše, vendar pa še ni niti jasnega koncepta, še manj pa strategije zoperstavljanja tovrstnemu vojskovanju. V tem poglavju bomo poskušali na kratko prikazati temeljne obrise, znotraj katerih se odvijajo razprave o tej problematiki.

Hibridno vojskovanje temelji na izkoriščanju slabosti nasprotnikov. Hoffman (2009, str. 38) meni, da je možno, da bo takšno vojskovanje učinkovito proti velikim, okornim in hierarhičnim organizacijam, ki so mentalno ali doktrinarno rigidne. Zato bo učinkovito zoperstavljanje zahtevalo hitro prilagajanje nepričakovanim novim situacijam in sposobnost inovativnega razmišljanja ter iskanja kreativnih rešitev. Ker hibridno vojskovanje temelji na raznovrstnosti sredstev in oblik, se pri tem povečuje pomen uporabe vseh instrumentov države, tako varnostnih, vojaških, diplomatskih, ekonomskih idr., kot tudi usklajeno delovanje na vseh teh področjih. Parameswaran (2015) na primer opozarja na pomen integriranega medresorskega pristopa in nasploh na potrebo po uporabi širšega nabora zmogljivosti ter koordinacije med njimi. Prikazani primeri hibridnega vojskovanja opozarjajo na pomen informacijskega delovanja, zato je pomembno, da zoperstavljanje poteka tudi na tem področju. Akterji v hibridnem vojskovanju za doseganje svojih ciljev praviloma uporabljajo tudi prikrivanje in ustvarjanje nejasnih situacij. Zato je zelo pomembno pravočasno zaznavanje in tudi pravilno razumevanje nasprotnikovih namenov.

Za vojaško organizacijo in druge državne strukture na področju varnosti je preučevanje in pripravljanje za soočanje z raznimi oblikami ogrožanja, ki jih lahko vsebuje hibridno vojskovanje, nujno, vendar pa je vse težje vnaprej načrtovati odzive na take grožnje. Čeprav hibridno vojskovanje obsega kombinacijo različnih oblik delovanja, pri katerem vojaško delovanje morda ni glavno, pa zoperstavljanje takemu vojskovanju ne zmanjšuje pomena dobre vojaške pripravljenosti. Delovanje v teh razmerah je za vojake kvečjemu še zahtevnejše. Izkušnje kažejo, da je hibridno vojskovanje tudi za dobro usposobljene vojske problem in da se premalo pripravljene in slabo organizirane vojske $\mathrm{v}$ takih spopadih zelo slabo izkažejo. ${ }^{25}$ Najpomembnejša je dobro opremljena in izurjena vojaška sila, ki dosega visoke profesionalne standarde. Poleg tega mora vojska razvijati sposobnosti hitrega prilagajanja razmeram in skupnega delovanja z drugimi sestavnimi deli nacionalnovarnostnega sistema.

${ }^{25}$ Izraelska vojska je leta 2006 v spopadih s Hezbolahom doživela znatne izgube. V primeru konflikta v Ukrajini se je pokazalo, da slabo organizirana in opremljena vojska ni kos uporniškim silam v regijah Donetsk in Lugansk. 
In ne nazadnje, primeri, ko je žrtev hibridnega vojskovanja država, kažejo, da je takšen nastop uspešen predvsem proti notranje nestabilnim državam, ki se spopadajo s problemi družbene kohezivnosti (notranjimi političnimi, etničnimi, verskim in drugimi nasprotji), ekonomskimi problemi, korupcijo, slabim upravljanjem države ipd. Zato lahko trdnost države in njen ekonomski razvoj razumemo kot enega ključnih dejavnikov v uspešnem zoperstavljanju grožnjam tovrstnega vojskovanja.

Hibridne grožnje so danes velik izziv za Nato. Po razmahu delovanja IS v Iraku in Siriji in po začetku konflikta v Ukrajini so vprašanja odziva na te grožnje v središču razprav znotraj zavezništva. Gre za grožnji, ki postavljata vprašanje ustreznosti Natovih mehanizmov odzivanja, vendar sta zelo različni in zahtevata tudi različne načine odzivanja. Kot so zapisali v poročilu iz konference o hibridnem vojskovanju, ${ }^{26}$ predstavlja Rusija neposredno grožnjo Natu; medtem se je treba IS upreti z »instrumentalizacijo regionalnih zaveznic« oziroma je mogoče IS poraziti tako, da se ob sodelovanju organizacij in držav iz regije na tem območju ponovno vzpostavijo delujoče države (Lindley-French, 2015, str. 7).

Politika Rusije je dejavnik, ki bistveno spreminja Natove strateško okolje in držo. Te spremembe pomenijo, da postaja med tremi ključnimi nalogami zavezništva vse pomembnejše zagotavljanje kolektivne obrambe. ${ }^{27}$ Čeprav ni velike verjetnosti odkritega vojaškega napada Rusije na katero od članic zavezništva, bi se moral Nato v takšnem primeru spoprijeti s številnimi dilemami:

»Dopustiti, da bi Rusija zasedla vsaj majhen del ozemlja Nata, bi imelo uničujoče posledice za kredibilnost zavezništva. Nato bi zato bil prisiljen z vojaško silo braniti napadeno zaveznico. Vendar, ali bi odkrita grožnja Rusije z jedrskim orožjem, kot smo jo videli v krizi v zvezi s Krimom in Donbasom, Nato odvrnila od takega posega? Če bi Nato z vojaško silo skušal povrniti zasedeno in bi Rusija izvedla omejen jedrski udar z namenom de-eskalacije konflikta, kako bi se Nato odzval? Na kratko, krepitev ruskih zmogljivosti in nova strategija prinašata vrsto težkih dilem, situacija pa zahteva temeljito prevrednotenje Natove obrambne strategije in postavitve« (Kroenig, 2015, str. 50).

Največjo skrb vzbuja možnost, da bi Rusija proti kateri od baltskih držav uporabila podoben scenarij kot v Ukrajini. V teh državah obstajajo odprti ali latentni konflikti z Rusijo. ${ }^{28}$ Takšen poseg bi zelo verjetno potekal brez neposredne in odkrite uporabe vojaških sredstev, zato ne bi bilo mogoče uporabiti 5. člena Severnoatlantske pogodbe (SAP) oziroma ne bi bilo podlage za izvajanje kolektivne obrambe. Pravzaprav

\footnotetext{
${ }^{26}$ NATO and New Ways of Warfare: Defeating Hybrid Threats, 29.-30. april, 2015. NDC Conference Report.

27 Strateški koncept Nata iz leta 2010 kot tri ključne naloge obravnava kolektivno obrambo, krizni menedžment in kolektivno varnost. Kroenig (2015, str. 57) meni, da bo kolektivna obramba morala postati Natova glavna naloga in da bo treba zmanjšati pozornost, namenjeno drugima dvema nalogama.

${ }^{28}$ Rusko govoreče manjšine živijo v Estoniji (25\% preb.) in Latviji (26\% preb.), v obeh so tudi določene napetosti med manjšinama ter večinskim prebivalstvom. VLitvi je ruskega prebivalstva manj (6\%), vendar so se leta 2014 zelo zaostrili njeni odnosi z Rusijo. Litva je ostra zagovornica sankcij proti Rusiji, na kar je Rusija odgovorila s povratnimi sankcijami in diplomatskimi potezami, celo z grožnjo prekinitve diplomatskih odnosov.
} 
Rusija šteje za zelo pomembno, da pri doseganju svojih ciljev Natu ne bi dala povoda za aktiviranje 5. člena SAP. Skrbi glede groženj, ki potekajo »pod pragom 5. člena« (angl. below the treshold of Article 5), so v Natu danes zelo izrazite. ${ }^{29}$ Ker bi se Nato s tradicionalnimi instrumenti kolektivne obrambe težko odzival na hibridno vojskovanje, bi v takšnih primerih bili najpomembnejši solidarnost in enotnost med zaveznicami.

Strokovnjaki opozarjajo, da v Natu še nimamo enotnega razumevanja glede uporabe, relevantnosti ali praktičnih koristi koncepta hibridnega vojskovanja (Jacobs, Lasconjarias, 2015, str. 2). Je pa enotno prepričanje zaveznic, da bo Nato v prihodnje moral oblikovati celovitejši pristop k temu problemu. Zavezništvo je decembra 2015 sprejelo Strategijo zoperstavljanja hibridnemu vojskovanju. Kot je povedal generalni sekretar Nata, strategija temelji na treh stebrih: pripravah, odvračanju in obrambi. Eden ključnih sestavnih delov te strategije je tudi krepitev sodelovanja v EU. ${ }^{30}$

Posledica spremenjene politike Rusije so tudi jasno izražena pričakovanja zaveznic v vzhodnem delu Nata, da mora zavezništvo oblikovati kredibilnejšo politiko obrambe. Na spremembe se je zavezništvo odzvalo $\mathrm{z}$ veliko aktivnostmi. Na političnem področju je pomemben korak v tej smeri Akcijski načrt pripravljenosti (angl. Readines Action Plan), sprejet na zasedanju v Walesu leta 2014. Na vojaškem področju so bile oblikovane Združene namenske sile v visoki pripravljenosti (Very High Readines Joint Task Force - VJTF) v velikosti kopenske brigade s pripadajočo podporo drugih zvrsti vojske. V zaveznicah na vzhodu (Bolgariji, Estoniji, Latviji, Litvi, Poljski in Romuniji) je Nato začel vzpostavljati elemente sistema poveljevanja, ki bi ob potrebi podpirali prihod zavezniških sil. Del odziva je tudi intenziviranje vojaških vaj in krepitev vojaškega sodelovanja, predvsem na področju usposabljanja z državami na vzhodnem obrobju. ${ }^{31}$

Poleg krepitve kakovosti in odzivnosti vojaških sil bo treba razviti še druge zmogljivosti. Jacobs in Lasconjarias (2015, str. 11) na primer opozarjata, da bo treba okrepiti kibernetsko obrambo, zmogljivosti za izvajanje psiholoških operacij, zmogljivosti za civilno-vojaško sodelovanje, obveščevalne zmogljivosti ter zmogljivosti za odzivanje na načrtno vodeno zlonamerno propagando. Nato, ki je

\footnotetext{
29 S tem so povezana tudi razmišljanja o spremembi 5. člena Severnoatlantske pogodbe, ki kot podlago za kolektivno obrambo šteje »oborožen napad « na katero od članic, tako da bi kot podlago za kolektivno obrambo upoštevali tudi druge vrste ogrožanja, na primer kibernetski napad, prikrito infiltracijo tujih oboroženih sil na ozemlje zaveznice, različne oblike hibridnega vojskovanja ipd. Več o tem glej Kroening, 2015, in Thornton, 2015. Doseganje konsenza v Natu o takšni spremembi se zdi zelo malo verjetno.

${ }^{30}$ Omenjena strategija je dokument zaupne narave, zato podrobnosti javnosti niso znane. Navedena stališča so bila predstavljena na tiskovni konferenci generalnega sekretarja Nata 1. decembra 2015. Vir: http://www.nato. int/cps/en/natohq/opinions_125362.htm?selectedLocale $=$ en.

${ }^{31}$ Nato je med 3. oktobrom in 6. novembrom 2015 izvedel vajo Trident Juncture, ki je bila največja vaja po letu 2002. Potekala je na ozemljih Italije, Śpanije in Portugalske ter v Sredozemskem morju. V njej je sodelovalo 36.000 vojakov, 140 letal in 60 plovil. Podlaga vaje je bil scenarij, po katerem neka večja država izvede invazijo na manjšo sosednjo državo in ogroža še tretjo državo. Nato na podlagi mandata VS ZN začne izvajati misijo za pomoč ogroženim državam in zagotavlja svobodno plovbo. Vaja je bila namenjena preverjanju pripravljenosti sil VJTF.
} 
predvsem vojaško-politična organizacija, se pravzaprav ne more ukvarjati s celotnim spektrom izzivov hibridnega vojskovanja. Za zdaj razvija predvsem politiko odvračanja, ki temelji na hitrem vojaškem odzivu. Za obsežnejše spopadanje s temi grožnjami pa mora Nato sodelovati z drugimi mednarodnimi organizacijami, posebno z EU (Pindjak, 2014).

Sklep Dosedanje razprave o hibridnem vojskovanju puščajo dvom o tem, ali je ta koncept upravičeno obravnavati kot novo kategorijo vojskovanja ali celo kot novo »revolucijo v vojaških zadevah«. Brez dvoma ta koncept opozarja na nove in širše dimenzije vojskovanja, ki bodo verjetno prisotne v vseh prihodnjih konfliktih. Priča bomo brisanju ločnice med vojaškim in nevojaškim delovanjem, uporabi vseh razpoložljivih sredstev in oblik delovanja, težnjam po ustvarjanju nejasnih situacij in vojskovanju, ki spreminja na Zahodu uveljavljene kulturne in civilizacijske norme vojaškega delovanja. V sodobnosti je vojna, vsaj v razvitem industrializiranem delu sveta, vse manj sprejemljiva in moralno upravičena. Najbrž ni odveč bojazen, da bodo hibridne oblike vojskovanja, s katerimi si njihovi izvajalci pravzaprav prizadevajo prikriti, da gre za vojno, postale prav zato sprejemljivejše in tudi bolj pogoste. Oblik hibridnega vojskovanja ne uporabljajo samo šibkejši udeleženci v spopadu z močnejšim nasprotnikom, kot je to praviloma v primeru asimetričnega vojskovanja. Takšne oblike vojskovanja lahko uporabljajo tudi močne države za pritisk na šibkejše nasprotnike, ker je to sprejemljivejše in tudi učinkovitejše ter zagotavlja možnost prikrivanja lastne vpletenosti.

Glede na raznovrstnost in izrazito prilagodljivost oblik hibridnega vojskovanja ni mogoče vnaprej načrtovati učinkovitih ukrepov upiranja. Lahko pa predvidimo, da je učinkovitost upiranja povezana vsaj s temi sestavnimi deli: 1. s socialnopolitično stabilnostjo družbe; 2. s sposobnostjo usklajenega odzivanja vseh državnih struktur; 3. s sposobnostjo skupnega delovanja znotraj mednarodnih ustanov; 4. z delovanjem profesionalnih vojaških sil, sposobnih operacij $\mathrm{v}$ nepredvidljivem in hitro spreminjajočem se okolju; 5. s pripravljenostjo prebivalstva, predvsem z vidika psihološko-propagandnih dimenzij vojskovanja. Vendar pa lahko danes v državah na območju Nata in EU na kar nekaj naštetih področjih najdemo tudi šibke točke.

Tudi v Sloveniji je nujen razmislek o tem, kaj nova strateška realnost, ki se trenutno kaže s pojavom hibridnega vojskovanja na vzhodnem in južnem obrobju Nata (Ukrajina, Sirija in Irak), prinaša v našo varnostno realnost. To bo verjetno zahtevalo tudi ponoven razmislek o ustreznosti veljavnih vojaško-strateških in doktrinarnih predpostavk. ${ }^{32}$ Zoperstavljanje hibridnim grožnjam ni zgolj vojaški problem, zato tudi obravnava ne more biti omejena samo na vojaško stroko, temveč zahteva sodelovanje vseh, ki se ukvarjajo z varnostjo v najširšem smislu.

V zadnjih dveh desetletjih je pri nas prevladalo prepričanje, da so vojaške grožnje zelo oddaljene. Dogajanja od leta 2014 naprej so takšna prepričanja relativizirala.

${ }^{32}$ Dokument Vojaška doktrina je bil sprejet leta 2006, od takrat pa ni doživel dopolnitev ali sprememb. 
Prisotnost konfliktov in tudi možnost oboroženih spopadov je postala večja kot kadar koli po koncu hladne vojne. Takšni konflikti najbrž ne bi pomenili neposredne teritorialne grožnje državi, vendar bi imeli veliko drugih posledic in bi terjali odziv. Članstvo v mednarodnih institucijah ne daje nujno trdnih varnostnih jamstev. Grožnje, ki imajo značaj hibridnega vojskovanja, so praviloma »pod pragom« 5. člena Severnoatlantske pogodbe, kar postavlja pod vprašaj izvajanje kolektivne obrambe. V takšnih primerih medsebojna pomoč med zaveznicami temelji predvsem na njihovi pripravljenosti in medsebojni solidarnosti. Vendar pa je, kot je pokazal primer »begunske krize« leta 2015, nacionalni interes pogosto bistveno močnejši motiv delovanja držav, kot je solidarnost.

Za zagotavljanje varnosti in obrambne sposobnosti so glavne zmogljivosti države. Ob vojskovanju, ki ima hibridni značaj, so nujne zelo raznovrstne zmogljivosti. Treba je povečevati sposobnost zaznavanja, analize in razumevanja varnostnega okolja in groženj v širšem okolju. $\mathrm{V}$ to spada tudi razumevanje sprememb vojskovanja, ki potekajo v sodobnosti. Obrambna sposobnost pa temelji na skupnem in usklajenem delovanju številnih državnih ustanov na različnih področjih. Eden najpomembnejših dejavnikov pa so vojaške zmogljivosti.

Vsi primeri sodobnega hibridnega vojskovanja kažejo na pomen dobro opremljenih, izurjenih, profesionalnih vojaških sil. Slovenska vojska po številnih merilih ne ustreza zahtevam sodobnega vojskovanja. Njene zmogljivosti so vprašljive zaradi razvojnega zaostajanja, ki je posledica nezadostnih finančnih sredstev. To se kaže predvsem v zastoju glede uvajanja nove sodobne oborožitve in opreme, zmanjšanju obsega stalne sestave vojske, vprašljivi kakovosti šolanja kadrov, zmanjšanju in nezadostni usposobljenosti prostovoljne rezerve idr. Za primer bistvenega poslabšanja varnostne situacije je bil vpeljan koncept vojaške strateške rezerve, ki pa je nedorečen, njegova izvedljivost in učinkovitost pa sta vprašljivi. V razmerah, ko se moramo spoprijeti s poslabšanjem varnostne situacije v širšem regionalnem okolju bo zanemarjanje razvoja vojaških zmogljivosti v prihodnosti vse težje opravičevati.

\section{Literatura}

1. Conflictbarometer, 2014. Heidelberg Institute for International Conflict Research. www. hiik.delen/konfliktbarometer/pdf/ConflictBarometer_2014.pdf(24. 8. 2015).

2. Ferris, J., 2010. Conventional Power and Contemporary Warfare. V Baylis, J. in drugi. Strategy in the Contemporary World. Oxford.

3. Fleming, B. P., 2011. The Hybrid Threat Concept. United States Army Command and General Staff College. Forth Leavenworth.

4. Freedman, L., 2014-2015. Ukraine and the Art of Limited War. Survival-Global Politics and Strategy, 56/št. 6.

5. Fromson, J., Simon, S., 2015. ISIS: The Dubious Paradise of Apocalypse Now. SurvivalGlobal Politics and Strategy, 57/st. 3.

6. Hoffman, F., 2009. Hybrid Warfare and Challenges. Joint Force Quarterly, 52/št. 1 .

7. Hoffman, F., 2014. On Not-So-New Warfare: Political Warfare vs Hybrid Threats. http:// warontherocks.com/2014/07/on-not-so-new-warfare-political-warfare-vs-hybrid-threats/ (2. 9. 2015). 
8. Jacobs, A., Lasconjarias, G., 2015. NATO's Hybrid Flanks. Rasearch Paper, NATO Defence College.

9. Johnson, D., 2015. Russia's Approach to Conflict-Implications for NATO's Deterrence and Defence. Rasearch Paper, NATO Defence College.

10. Kiras, J., 2008, Irregular Warfare. V Jordan, D. idr. Understanding Modern Warfare. Cambridge Univesity Press. Cambridge.

11. Kroenig, M., 2015. Facing Reality: Getting NATO Ready for a New Cold War. SurvivalGlobal Politics and Strategy, 57/št. 1.

12. Lindley-French, J., 2015. NATO and New Ways of Warfare: Defeating Hybrid Threats. NDC Conference Report. Research Division - NATO Defense College.

13. Lonsdale, D., 2008. Strategy. V Jordan, D. idr. Understanding Modern Warfare. Cambridge Univesity Press. Cambridge.

14. McCuen, J., 2008. Hybrid Wars. Military Review, March-April 2008.

15. Military Balance, 2015. Routledge. London.

16. Palmer, D. A. R., 2015. Back to the Future? Russia's hybrid warfare, revolutions in military affairs, and Cold War comparisons. Rasearch Paper, NATO Defence College.

17. Parameswaran, P., 2015. Are We Prepared for 'Hybrid Warfare'? http://thediplomat. com/2015/02/are-we-prepared-for-hybrid-warfare/ (21. 8. 2015).

18. Pindjak, P., 2014. Deterring Hybrid Warfare: a chance for NATO and EU to work together. NATO Review, November 2014.

19. Piotrowski, M., A., 2015. Hezbollah: The Model of a Hybrid Threat. PISM Bulletin. http:// www.pism.pl/files/?id_plik=19320.

20. Reisinger, H., Goltz, A., 2014. Russia's Hybrid Warfare. Rasearch Paper, NATO Defence College.

21. Rühle, M., Grubliauskas, J., 2015. Energy as a Tool of Hybrid Warfare. Rasearch Paper, NATO Defence College.

22. Schadlow, N., 2015. The Problem with Hybrid Warfare. http://warontherocks. com/2015/04/the-problem-with-hybrid-warfare/ (17. 9. 2015).

23. Speck, U., 2014. How the EU Sleepwalked Into a Conflict With Russia. http://www. carnegieeurope.eu/2014/07/10/how-eu-sleepwalked-into-conflict-with-russia/hfjn (2. 7. 2015).

24. Speller, I., Tuck, C., 2008. Introduction. V Jordan, D. idr. Understanding Modern Warfare. Cambridge Univesity Press. Cambridge.

25. Svete, U., Guštin, D., Prebilič, V., 2010. Asimetrija in vojaška organiziranost: slovenske izkušnje. VMalešič, M., (ur.) Mednarodne razsežnosti varnosti Slovenije. Ljubljana, Fakulteta za družbene vede.

26. Škerbinc, M., 2015. Hibridno vojskovanje. Revija Obramba, maj 2015.

27. Thornton, R., 2015. The Changing Nature of Modern Warfare: Responding to Russian Information Warfare. RUSI Journal, 160/št. 4. 
Viktor Potočnik

\section{KONCEPT EŠALONIRANJA OGNJEV IN SISTEMI OGNJENE PODPORE V SLOVENSKI VOJSKI}

\section{ECHELONMENT OF FIRES AND INDIRECT FIRE SYSTEMS IN THE SLOVENIAN ARMED FORCES}

Povzetek V članku se ukvarjamo s konceptom ešaloniranja ognjev. Zmogljivosti sistemov za ognjeno podporo pri majhnih vojskah so omejene, zato je pravilna in smotrna upraba koncepta ešaloniranja ognjev bistvena za uspeh na bojišču. Hkrati pa predvsem manjše članice Nata upravičeno pričakujejo, da bodo v operacijah zavezništva deležne tudi učinkov sistemov združene ognjene podpore, ki jih imajo na voljo velike države. V nadaljevanju predstavimo koncept ešaloniranja ognjev in njegov vpliv na oblikovanje dobrega sistema ognjene podpore na taktični ravni, od ravni voda do brigade. Nazadnje pa pogledamo na zmogljivosti Slovenske vojske in njenih sistemov za posredne ognje znotraj širšega sistema ognjene podpore Slovenske vojske in združene ognjene podpore zavezništva ter navedemo nekaj ključnih ugotovitev, ki bi lahko služile kot premislek pri nadaljnji gradnji zmogljivosti Slovenske vojske.

Ključne Slovenska vojska (SV), manever, ešaloniranje ognjev, artilerija, minometi, ognjena besede podpora, združena ognjena podpora, sistemi za posredne ognje.

Abstract The article discusses the concept of echelonment of fires. Small armed forces such as the Slovenian Armed Forces (SAF) have a limited joint fires capability. Therefore, in order to succeed on the battlefield, they have to correctly apply the principles of echelonment of fires. Additionally, smaller NATO members rightfully expect to receive some of the Joint Fires Effects from larger member armies in the Joint Operational Environment. The article looks at the Joint Fire Support and indirect fire systems, and what the terms mean for small NATO member states with limited capabilities. It then goes on to present the concept of echelonment of fires and some key terms within the concept. Lastly, it looks at SAF capabilities through the echelonment of fires concept and Indirect Fire Systems. The author also puts forward some suggestions for future development of SAF capabilities.

Key words Slovenian Armed Forces, manoeuvre, echelonment of fires, artilery, mortars, fire support, joint fire support, indirect fire systems. 
Uvod Slovenska vojska je avgusta 2015 prvič po letu 1997 opravila pripravljalno streljanje z minometi $60 \mathrm{~mm}$, ki so bili iz operativne uporabe umaknjeni leta 2001 (Pišlar, 2015, str. 20). To pomeni, da je bila od takrat brez minometne ognjene podpore na najnižjih taktičnih ravneh voda in čete. Nekateri bodo sicer trdili, da ni tako in da so bili minometi te vrste nadomeščeni z bombometi (ročnimi, podcevnimi in avtomatskimi), s čimer pa se ne strinjamo, razlaga je zapisana v točki 4. Vzroki, da so bili minometi leta 2001 umaknjeni iz uporabe, so nedvomno kompleksni, ostaja pa dejstvo, da je SV imela manko v eni ključnih zmogljivosti.

Razmere v ognjeni podpori v SV nikakor niso zavidljive. Uvod v koncept združene ognjene podpore $\mathrm{SV}^{1}$ ugotavlja, da je »/.../ v SV sodelovanje enot bojne podpore $\mathrm{z}$ bojnimi enotami omejeno« (Koncept, 2015, str. 4). Bistveni pa sta vprašanji, kaj z združeno ognjeno podporo v SV sploh želimo doseči in ali sploh lahko govorimo o združeni ognjeni podpori na ravni SV. Odgovor nanju zahteva jasno vizijo delovanja sistema ognjene podpore od ravni voda do ravni brigade.

Namen članka je preprost: oblikovati pogled SV na vlogo in nalogo sistemov, ki zagotavljajo posredne ognje za ognjeno podporo na taktični ravni od ravni voda do brigade. V članku bomo to naredili z razlago koncepta ešaloniranja ognjev in njegovega pomena za uspeh ognja in manevra na bojišču. Najprej bomo povzeli nekaj teoretičnih podlag, nujnih za razumevanje vloge ognjene podpore na bojišču, in opredelili pojme, ki jih srečujemo pri obravnavi združene ognjene podpore $\mathrm{v}$ majhnih oboroženih silah, kakršna je SV. Nato bomo na zagotavljanje ognjev za manever pogledali z vidika koncepta ešaloniranja ognjev in njegove vloge pri zagotavljanju razmer za uspeh manevra. Nazadnje pa bomo prek koncepta ešaloniranja ognjev in sistemov posredne ognjene podpore analizirali stanje »združene« ognjene podpore v SV.

\section{ZDRUŽENA OGNJENA PODPORA}

\section{a) Teoretična podlaga}

Clausewitz je zapisal »/.../ vojaška aktivnost ni nikoli usmerjena samo proti materialnim sredstvom, vedno je hkrati usmerjena tudi proti moralni sili, ki jim daje življenje, in teh dveh (materialne in moralne sile) ne moremo ločevati« (Johnson, 2000, str. 8). Na podlagi tega je Schneider razvil model procesa uničevanja človeške volje v boju (glej sliko 1), za kar uporablja prispodobe fizične, kibernetske in moralne domene. Poenostavljeno povedano gre enota $\mathrm{v}$ boj kot kohezivna celota, nato pa $\mathrm{s}$ časom, predvsem zaradi hitrosti uničevanja, njena kohezivnost pada in enota postaja vse bolj dezorganizirana. Dezorganizacija vpliva predvsem na funkcije poveljevanja, kontrole in komunikacije, ki zagotavljajo organizacijo enote. Če te še naprej slabijo kot posledica nadaljnjega uničevanja, dezorganizacija preide $\mathrm{v}$ dezintegracijo oziroma popoln zlom kohezije in organizacije enote (Johnson, 2000, str. 9).

Koncept je bil podpisan in velja. Ni pa še bil uveljavljen in je v pripravi za eksperiment, zato ga v članku niti ne obravnavamo. Tu samo povzemamo ugotovitve o trenutnem stanju ognjene podpore $v S V$. 
Slika 1:

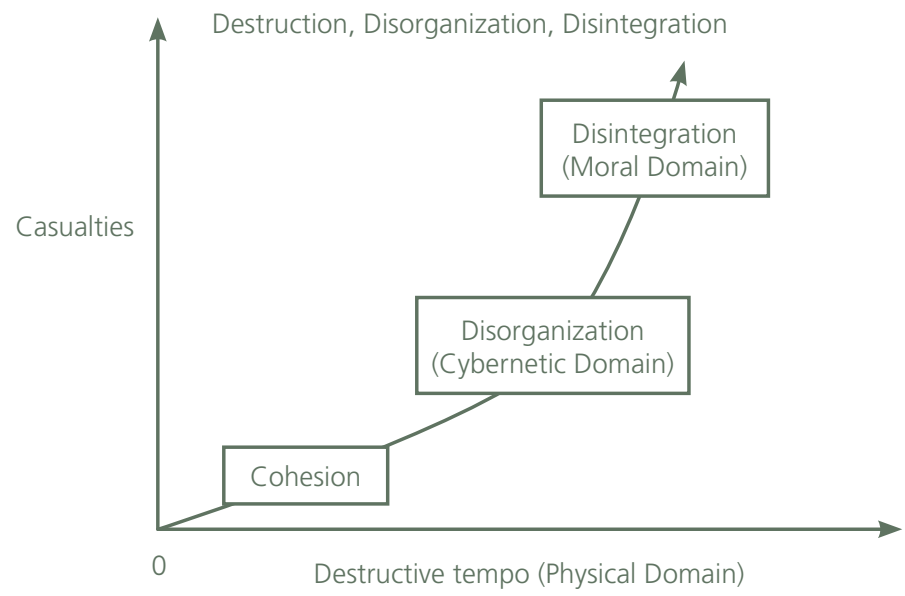

Dr. Schneider's model

V Schneiderjevem modelu je proces uničevanja nespremenljiv dejavnik na bojišču in vzrok izgube volje do bojevanja. Pri tem je vloga poveljnika na bojišču, da vzpostavi, vzdržuje in regenerira primarne skupine (enote) kot sredstvo za vzdrževanje volje do bojevanja. Ko so s časom oborožitveni sistemi postajali zmogljivejši in proces uničevanja vse učinkovitejši, so vojaške enote postajale vse manjše, bolj razpršene in so izgubljale organizacijsko kohezivnost. Prihajalo je do dezintegracije. Da bi zmanjšale učinke dezintegracije in osredotočile delovanje razpršenih sil, so vojaške organizacije izboljševale poveljevanje, kontrolo in komunikacijo ter organizacijsko strukturo. Združevanje ognjev z manevrom je bil eden izmed načinov, kako so vojske skušale osredotočiti bojno moč na točki odločitve (Johnson, 2000, str. 6-16).

Ogenj in manever se nanašata na uporabo vseh posrednih in neposrednih ognjev vojaške formacije pri združenem bojevanju rodov, s katerimi ta skuša doseči prednost na bojišču. Manever kot kombinacija ognja in premika pa je značilen za manevrsko enoto in se nanaša na njeno sposobnost uporabe neposrednih ognjev v podpori premiku enega dela enote. Razlikovanje med ognjem in manevrom je pomembno, ko govorimo o vlogi ognjene podpore na bojišču. Glede na to, da sta ogenj in manever primarna načina doseganja pozicije prednosti na bojišču, s katere bo enota, ki izvaja združeno bojevanje rodov, dosegla zase ugodno odločitev, je razumljivo, da sta ogenj in manever dve neločljivi sili (Johnson, 2000, str. 19).

Če torej povzamemo, Schneiderjev model pojasni vzroke za povečevanje ognjene moči vojaških formacij. Kot v svoji študiji ugotavlja Johnson, povečevanje ognjene moči in večanje natančnosti orožij vodita v še večjo disperzijo sovražnika in delovanje v vse manjših enotah, kar povzroča dezorganizacijo in dezintegracijo, zaradi česar 
morajo tudi lastne sile delovati v vse manjših enotah, da bi lahko odgovorile na disperzijo sovražnika. To hkrati pomeni, da morajo imeti lastne enote na vseh nižjih taktičnih ravneh dostop do ustreznih sistemov ognjene podpore, da bi lahko ustvarile dovolj bojne moči na točki odločitve (Johnson, 2000, str. 25).

\section{b) Terminologija}

Na področju ognjene podpore je nekaj terminoloških zadreg. S prevzemom Natovih doktrin in standardov so se v SV pojavili nekateri termini, za katere v slovarjih in terminoloških zbirkah ne najdemo neposrednih prevodov, niti jih ni v veljavni doktrini SV (2006).

Združene ognje(angl.joint fires) zavezništvo opredeljuje kot»/.../ ognje, ki se izvajajo med uporabo sil, sestavljenih iz dveh ali več komponent (zvrsti), v koordinirani akciji za dosego skupnega cilja« (AAP-6, 2013, str. 2-J-1)2. Združeno ognjeno podporo (angl. joint fire support) pa kot $» / . . . /$ koordinirano in integrirano uporabo vseh oborožitvenih platform, ki zagotavljajo ognje ${ }^{3}$, da bi dosegli želene učinke na zemeljske cilje v podpori kopenskih operacij v celotnem spektru spopadov. Obsega integracijo posrednih ognjev in učinkov z namenom vplivanja na sovražnikove sile, infrastrukturo in funkcije« (AartyP-5(A), 2011, str. 1-1) ${ }^{4}$.

Ko v zavezništvu govorijo o združenem, govorijo o »/.../ aktivnostih, delovanju in organizacijah, v katerih sodelujejo elementi vsaj dveh različnih zvrsti oboroženih sil« (AAP-6, 2013, str. 2-J-1). Znotraj zavezništva pa imajo majhne vojske, kot so na primer oborožene sile Litve, Latvije, Estonije in Slovenije, zelo omejene zmogljivosti po zvrsteh (Hacket, 2015, str. 87, 88, 111-114). SV zvrsti formalno sploh ne pozna, pomorstvo in letalstvo sta samo rodova znotraj enotne organizacije vojske (ZObr, 2004, 40. člen).

Doktrina SV (2006) ne pozna pojmov združeni ognji in združena ognjena podpora, opredeljuje zgolj ognjeno podporo, in sicer kot »/.../ skupno in usklajeno uporabo ognjenega delovanja kopenskih, mornariških in zračnih bojnih sistemov in delovanja ofenzivnih sistemov elektronskega bojevanja ter neubojnih sredstev na cilje na kopnem ali morju« (Furlan in drugi, 2006, str. 99).

Ko torej govorimo o pojmu združeno na primeru majhnih vojsk, se je treba zavedati, da imajo te vojske, četudi poznajo različne zvrsti oboroženih sil, precejšnje omejitve v vseh zvrsteh, še posebno pa v zmogljivostih mornariške in letalske komponente. Pri SV pa sploh težko govorimo o združeni ognjeni podpori, saj nima zvrsti in lahko o tej podpori govorimo le, ko SV s svojimi zmogljivostmi deluje v zavezništvu.

\footnotetext{
Fires applied during the employment of forces from two or more components, in coordinated action toward a common objective.

3 Ti vključujejo tudi kopenske, zračne in mornariške posredne ognje.

4 JFS is the coordinated and integrated employment of all weapon platforms delivering fires to achieve the required effects on ground targets to support land operations in the full spectrum of conflict. It encompasses the integration of indirect fires and effects in order to influence the adversary forces, installations or functions.
} 
Slika 2:

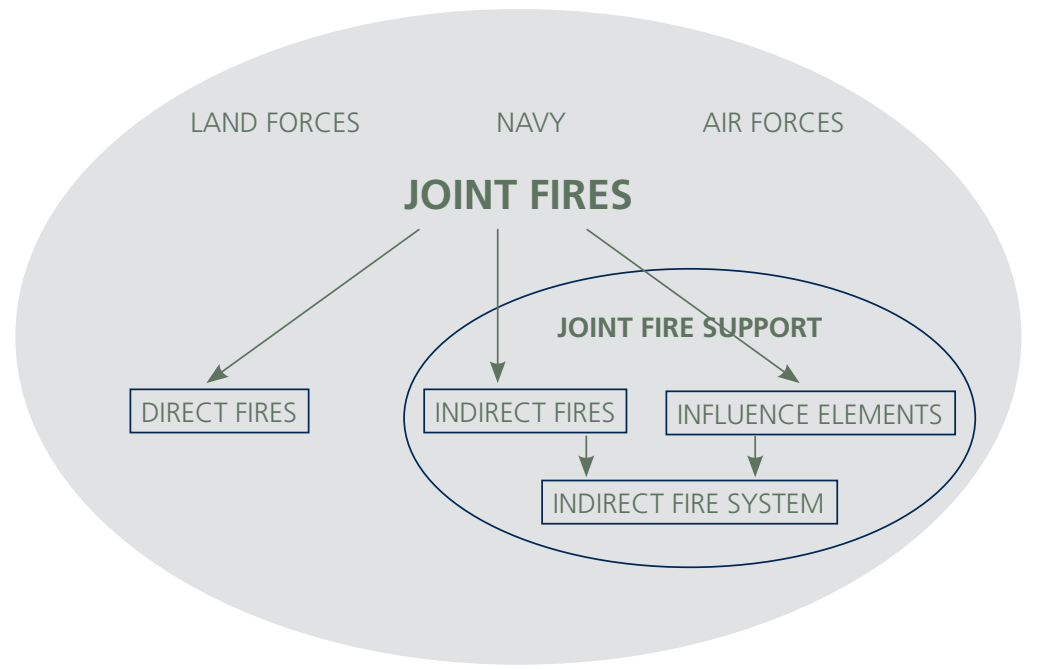

V zavezniški doktrini se pojavlja tudi izraz indirect fire support (Stanag 2484(2), Stanag 2605, Stanag 2490), za katerega pa pri nas nimamo uradnega prevoda niti ni Natove definicije izraza. V kontekstu Natovih dokumentov je po avtorjevem mnenju najprimernejši prevod posredna ognjena podpora, ki pomeni ognje, ki jih za manever zagotavljajo kopenski sistemi za posredno delovanje. Tudi pregled izrazov, opredeljenih v Vojni enciklopediji (druga izdaja), avtorju ni dal jasnega odgovora na terminološke zadrege. Izraz vatrena podrška (Gažević, 1975, str. 330) je v njej opredeljen kot sinonim za Natov fire support, taka je tudi razlaga pojma, medtem ko za pojem (ne)posredna podrška najdemo razlago, da gre za podporo, ki (ne)posredno vpliva na potek boja (Gažević, 1973, str. 786). Izraza, ki bi ustrezal Natovemu indirect fire support, v enciklopediji ne najdemo.

$\mathrm{V}$ tem članku bomo v delu, ki se nanaša na SV, zato govorili o združeni ognjeni podpori, in sicer z jasnim zavedanjem, da govorimo le o zmogljivostih različnih rodov SV ter da so te $\mathrm{v}$ mornariški in zračni komponenti zelo omejene. Poleg tega bomo za izraza indirect fire support ter indirect fire system uporabljali termina posredna ognjena podpora in sistemi za posredni ogenj.

\section{c) Sistemi za posredni ogenj}

Zavezniška taktična doktrina sistemov za posredni ogenj opredeljuje, kateri so ti sistemi po posameznih zvrsteh. V kopensko komponento zavezništvo šteje minomete ter cevno in raketno artilerijo, v zračno komponento pa letala z zmogljivostmi protipovršinskega delovanja (na morju), onemogočanja iz zraka in neposredne zračne podpore. Pri tem mora biti delovanje te komponente vedno podprto $\mathrm{s}$ kvalificiranimi skupinami za zračno taktično kontrolo. V zračno komponento spadajo 
tudi helikopterji z onemogočanjem iz zraka in bližnjo bojno podporo ter bojna brezpilotna letala. Mornariško komponento v zavezništvu sestavljajo vsi mornariški sistemi za posredne ognje. V vseh treh komponentah sistemi uporabljajo vodene in nevodene izstrelke (AartyP-5(A), 2011, str. 3-1 do 3-3).

$\mathrm{Na}$ prvi pogled je seveda očitno, da so zmogljivosti majhnih oboroženih sil po posameznih komponentah zelo omejene. Doktrina SV navaja, da »/.../ obstajajo naslednje vrste ognjene podpore: artilerijska podpora, minometna podpora, onemogočanje iz zraka in neposredna zračna podpora« (Furlan in drugi, 2006, str. 99). $\mathrm{V}$ resnici imajo vse naštete zmogljivosti na voljo le največje vojske zavezništva. Se pa zmogljivosti vseh teh sistemov pojavljajo v skupnih operacijah zavezništva, v katerih s svojimi zmogljivostmi delujejo tudi najmanjše članice. Doktrina SV celo eksplicitno navaja, da »/.../ vojaška obramba Republike Slovenije temelji na uporabi združenih sil zavezništva, v katerih bodo integrirane sile Slovenske vojske« (Furlan in drugi, 2006, str. 13).

\section{KONCEPT EŠALONIRANJA OGNJEV}

Zavezništvo opredeljuje manever ${ }^{5}$ kot $\gg /$.../ uporabo sil na bojišču s premiki in $\mathrm{V}$ povezavi z ognjem ali ognjenimi delovanji za dosego prednostnega položaja glede na sovražnika v izvedbi naloge« (Brinc in drugi, 2006, str. 148). Vojaška doktrina SV pa manever opredeljuje kot $» / .$. / uporabo sil s premikom v kombinaciji s hitrostjo in ognjeno močjo. Manever je osnovni dejavnik osredotočenja bojne moči na odločilni točki in dejavnik gospodarne uporabe sil in doseganja presenečenja (Furlan in drugi, 2006, str. 96). Preprosteje povedano je manever kombiniranje ognja in premika.

Za ognje, ki zagotavljajo dezintegracijo sovražnika in s tem omogočajo premik, pa je ključno razumevanje koncepta njihovega ešaloniranja. Pojem ešaloniranja, kot je opredeljen v Vojni enciklopediji, se razume kot razporejanje po globini (Gažević, 1971, str. 707). Podrobneje pa koncept opredeljuje doktrina kopenske vojske ZDA. Koncept je relevanten tako $\mathrm{v}$ izvajanju ofenzivnega kot defenzivnega delovanja. Namen ešaloniranja ognjev je vzdrževanje ognja na cilju z optimalnim oborožitvenim sistemom, dokler se lastne sile ne približajo na razdaljo do cilja, ki jo v boju določa tako imenovana razdalja sprejemljivega tveganja (angl. risk estimate distance RED) ${ }^{6}$ za vsak posamezni oborožitveni sistem (FM 3-21.10, 2006, str. 10-21).

Koncept ešaloniranja ognjev zahteva, da se na cilje začne delovati z oborožitvenim sistemom z največjo razdaljo sprejemljivega tveganja. Ko manevrska enota na poti do cilja prečka razdaljo določenega sistema, ogenj tega sistema prekinemo, premaknemo ali prenesemo na drug cilj. To sproži delovanje na cilj s sistemom z naslednjo manjšo razdaljo sprejemljivega tveganja. Čas delovanja po cilju s posameznim sistemom

\footnotetext{
Employment of forces on the battlefield through movement in combination with fire, or fire potential, to achieve a position of advantage in respect to the enemy in order to accomplish the mission.

${ }_{6}$ Pri usposabljanju namesto razdalje sprejemljivega tveganja uporabljamo minimalno varno razdaljo (angl. minimum safety distance-MSD).
} 
je povezan s hitrostjo premika lastnih sil med posameznimi linijami razdalj sprejemljivega tveganja. Proces se nadaljuje do točke, ko oborožitveni sistem z najmanjšo razdaljo sprejemljivega tveganja neha delovati in lastne sile lahko uničijo sovražnika z neposredim ognjem ali so v položaju za izvedbo zaključnega juriša in zavzetje cilja (FM 3-21.10, 2006, str. 10-21).

Za razumevanje koncepta ešaloniranja ognjev je nujno tudi jasno razumevanje pojmov risk estamated distance, minimum safe distance in danger close (bližina lastnih sil). Natančneje te pojme opredeljuje ustrezna zavezniška doktrina, pa tudi publikacija JFIRE (JFIRE, 2012, str. 143-144, 155).

Na kratko pa je razdalja sprejemljivega tveganja tista, ki služi za ešaloniranje ognjev v boju, minimalna varna razdalja ${ }^{7}$ pa v miru med usposabljanjem. Bližina lastnih sil ${ }^{8}$ pa je zgolj opozorilo na povečano tveganje.

\section{EŠALONIRANJE OGNJEV IN SISTEMI OGNJENE PODPORE}

Publikacija JFIRE opredeljuje razdaljo sprejemljivega tveganja in minimalno varno razdaljo za različne sisteme, ki jih uporabljajo v oboroženih silah ZDA, pa tudi v nekaterih drugih članicah Nata. Razdalje, navedene v publikaciji, nam prikazujejo uporabnost koncepta ešaloniranja ognjev. V spodnji tabeli 1 je izvleček teh razdalj za različne oborožitvene sisteme. Nekatere ekvivalente uporabljajo tudi v SV.

Tabela 1:

\begin{tabular}{|l|c|c|c|c|c|}
\hline & & & \multicolumn{2}{|c|}{ RED $(\mathrm{m})$} & \\
\hline oborožitveni sistem & SV & strelivo & stoje & leže & opomba \\
\hline minomet M 224 & M 57 & $60 \mathrm{~mm} \mathrm{HE}$ & 125 & 120 & $2 / 3$ maks. \\
\hline minomet M 252 & $/$ & $81 \mathrm{~mm} \mathrm{HE}$ & 195 & 190 & $2 / 3$ maks. \\
\hline nevodene rakete 70 mm & (PC-9 M) & $70 \mathrm{~mm}$ & 290 & 265 & kontaktni vž. \\
\hline havbica M 119 & $/$ & $105 \mathrm{~mm} \mathrm{HE}$ & 300 & 285 & $2 / 3$ maks. \\
\hline Mk 82 & (PC-9 M) & $500 \mathrm{~kg}$ & 310 & 235 & kontaktni vž. \\
\hline minomet M 120 & MN-9 & $120 \mathrm{~mm} \mathrm{HE}$ & 395 & 365 & $2 / 3$ maks. \\
\hline top-havbica M 109 & TN 90 & $155 \mathrm{~mm} \mathrm{HE}$ & 460 & 440 & $2 / 3$ maks. \\
\hline
\end{tabular}

V praksi pomeni, da se kot minimalne varne razdalje za usposabljanje uporabljajo razdalje, ki jih za posamezne sisteme določijo na posebnem vadišču - v upravi strelišča oziroma vadišča. Le če vadišče/strelišče teh razdalj ne določa, se lahko uporabljajo splošne, kot so zapisane npr. v JFIRE.

8 Razdalja danger close (bližina lastnih sil) za minomete in cevno artilerijo je $600 \mathrm{~m}$, za mornariške topove pa $750 \mathrm{~m}$. Za vse druge sisteme je določena posebej in običajno ustreza 0,1\% PI za stoječo osebo. 
Grafikon 1 kaže, kako pomembna je uporaba različnih sistemov ognjene podpore za delovanje koncepta ešaloniranja ognjev. S konceptom ešaloniranja ognjev in uporabo sistemov različnih zvrsti oziroma rodov manevrsko enoto razmeroma varno pripeljemo na razdaljo 125 metrov do sovražnikovih položajev. Zadnjih 125 metrov je vedno najtežjih in jih je treba premagati s pomočjo neposrednih ognjev in odločnega juriša pehote na nasprotnikove položaje. Če izpustimo enega izmed sistemov ognjene podpore, se nam v konceptu ešaloniranja ognjev pojavi vrzel, ki jo morajo pokriti drugi sistemi ali pa se poveča tveganje izpostavljenosti lastnih sil.

Grafikon 1:

Ešaloniranje ognjev
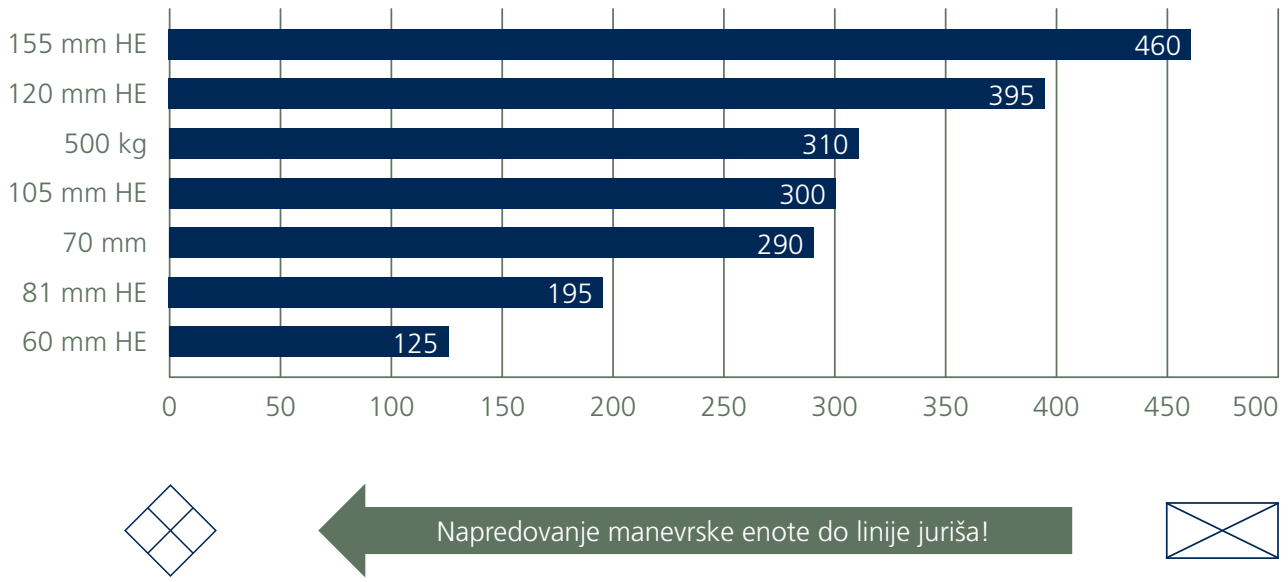

Napredovanje manevrske enote do linije juriša!

Ponazorimo s primerom. Recimo, da je manevrski enoti iz grafikona 1 na voljo le minometna podpora $60 \mathrm{~mm}$ in $120 \mathrm{~mm}$ ter podpora artilerije $155 \mathrm{~mm}$. To pomeni, da ima manevrska enota v približevanju nasprotniku med minometi $120 \mathrm{~mm}$ in $60 \mathrm{~mm}$ 200-metrsko vrzel, ki jo morajo pokriti minometi $60 \mathrm{~mm}$. Za premagovanje 200metrske razdalje bi pehota porabila približno 30 minut $^{9}$. To pomeni dodatnih 750 izstreljenih 60 -milimetrskih minometnih $\min ^{10}$. To so velike številke za raven enote, v kateri so 60-milimetrski minometi, in močno presegajo bojne komplete za takšno oborožitev. To pomeni približno $975 \mathrm{~kg}$ streliva $60 \mathrm{~mm}$, ki bi ga morali nositi vojaki v

\footnotetext{
Izračun temelji na teh predpostavkah: dnevni premik ob dobri vidljivosti, 50 \% vlažnost, 15 stopinj Celzija zračne temperature, 50 stopinj naklona terena. Za te razmere je predvidena hitrost premika 0,1 m/s. Avtor meni, da so te predpostavke ustrezne glede na povprečne letne temperature in vlažnost v Sloveniji. 50-stopinjski naklon pa je bil izbran, ker predstavlja najtežje mogoče razmere na terenu. Hitrosti premikanja v tabeli namreč veljajo za nebojno situacijo oz. fazo premika v zbirni rajon. Ko dodamo dejavnik nevarnosti in stresa, ki se pojavi pri premiku z izhodiščnega na jurišni položaj, se te hitrosti zelo zmanjšajo. To zmanjšanje hitrosti v tabeli najbolje ponazori naklon terena (Hayes, 1996, str. 52).

${ }_{10}$ Za 60-milimetrski minomet, kakršen je M57 v SV, je hitrost streljanja, ki se lahko vzdržuje dlje časa, do 25 min na minuto (Stanimirović, 1973, str 10).
} 
pehotni četi ${ }^{11}$, kakršna je pehotna četa SV brez vozil. Prva alternativa temu je manjša gostota minometnega ognja $\mathrm{v}$ podpori manevru enote, kar pomeni večjo verjetnost izpostavljenosti sovražnikovemu ognju. Druga možnost pa je uporaba ognjev drugih sistemov, kot so minometi $81 \mathrm{~mm}$ ter ognji letalskih in mornariških sil.

Poveljujoči seveda nikoli nima na voljo dovolj streliva, da bi zadostil teoretičnim potrebam v podpori manevru, zato se bo morala enota zanašati na njegovo sposobnost presoje tveganja in racionalne uporabe sredstev. Z zgornjim primerom poskušamo zgolj ponazoriti, kako se težave množijo, če izpuščamo oborožitvene sisteme pri ešaloniranju ognjev.

Če zdaj prek koncepta ešaloniranja ognjev pogledamo formacije enot na ravni brigade $\mathrm{v}$ treh vojskah, ki so reference za vse druge, ugotovimo, da ima ameriška pehotna brigada na ravni brigade bataljon havbic $105 \mathrm{~mm}$ (16 cevi), na ravni pehotnega bataljona pa $\mathrm{v}$ minometnem vodu po štiri minomete $120 \mathrm{~mm}$ in štiri minomete $81 \mathrm{~mm}$, na ravni pehotne čete pa najdemo dva minometa $60 \mathrm{~mm}$ (FKSM, 2010, str. B-21, B-23, B-35). Brigada Stryker ima v artilerijskem bataljonu na ravni brigade 12 havbic $155 \mathrm{~mm}$. Na ravni bataljona Stryker pa ima štiri minomete $81 \mathrm{~mm}$ in na ravni čete dva minometa $60 \mathrm{~mm}$ (FKSM, 2010, str. C-16, C-18, C-29).

Britanci so nekoliko bolj prilagodljivi in artilerijo na ravni brigade kombinirajo skladno s potrebami. Običajno jo predstavlja osem 105-milimetrskih ali 155-milimetrskih topov/havbic, organiziranih $\mathrm{v}$ artilerijski bataljon ${ }^{12}$. Na ravni bataljonov imajo minometne vode $\mathrm{s}$ po šestimi 81 -milimetrskimi minometi in na ravni čete po tri 60-milimetrske minomete (The British Army, 2015).

Brigade oboroženih sil Ruske federacije poznajo artilerijske bataljone s sistemi kalibra $152 \mathrm{~mm}$ in bataljone raketne artilerije. Na ravni bataljonov pa imajo minometne čete, v katerih kombinirajo minomete $120 \mathrm{~mm}$ (8 orožij) ali $82 \mathrm{~mm}$ (8 orožij). Na ravni pehotne čete poznajo 60-milimetrske minomete (Ortman, 2015).

Priloge 4, 5 in 6 grafično prikazujejo organiziranost minometnih in artilerijskih sistemov v prej omenjenih oboroženih silah, vendar smo jih za članek omejili na dva manevrska elementa v brigadi, da bi lažje primerjali stanje v SV. Treba je vedeti, da ima sodobna brigada tri do pet manevrskih elementov v rangu bataljona, od katerih je vsaj en izvidniški.

Vse omenjene vojske predpostavljajo vsaj lokalno prevlado $\mathrm{v}$ zraku, tako da bi bile manevrskim enotam na bojišču na voljo tudi zmogljivosti neposredne zračne podpore in ob delovanju v priobalnem pasu tudi zmogljivosti mornariških ognjev.

\footnotetext{
${ }^{I I}$ MM 60 mm je četno orožje, kar pomeni da se njegovo breme lahko razporedi na vse vojake v četi. Če ima četa pribl. 110 pripadnikov, ki lahko nosijo dodatno breme, to pomeni dodatnih $9 \mathrm{~kg}$ na posameznika.

${ }_{12}$ Brigadna artilerijska skupina ima lahko na voljo tudi MLRS-sisteme. Zanimiva je opazka, da so OS Hrvaške pred kratkim objavile namero pridobiti iz ZDA 16 MLRS-sistemov.
} 
Sem lahko štejemo tudi zmogljivosti manevrirnih raket in raketne artilerije, za katero razdalje več sto kilometrov navadno ne pomenijo ovir.

Za koncept ešaloniranja ognjev je skoraj nepomembno, ali govorimo o ubojnih ali neubojnih učinkih. Gre za to, da sovražniku preprečimo delovanje na naše sile, kar pomeni, da ne gre nujno za ubojne učinke. Če z delovanjem elementov vplivanja, kot so operacije civilno-vojaškega delovanja, psihološke operacije in informacijske operacije, lahko zagotovimo varnost lastnega manevra, to lahko razumemo v smislu koncepta ešaloniranja ognjev. Za racionalno uporabo razpoložljivih virov je pri ešaloniranju ognjev nujno upoštevati vse elemente združene ognjene podpore, kar dosežemo z izbiro ciljev in delovanjem nanje (angl. targeting).

\section{SLOVENSKA VOJSKA IN EŠALONIRANJE OGNJEV}

Kot je bilo že ugotovljeno, je bila SV med letoma 2001 in 2015 na taktični ravni brez sistemov za posredni ogenj, manjših od $120 \mathrm{~mm}$. Kot je prikazano v tabeli in grafikonu 1, to pomeni, da se je ešaloniranje ognjev s sistemi za posredni ogenj končalo 395 metrov od cilja, kar pomeni 270 metrov izpostavljenosti ${ }^{13}$ oziroma $\mathrm{v}$ fazi približevanja cilju več kot dodatne pol ure izpostavljenosti sovražnikovemu ognju. Tega ne more nadomestiti nobena zaščitna oprema posameznika ali oklepna zaščita vozila. Pol ure in več izpostavljenosti organiziranemu in discipliniranemu sovražniku pomeni skoraj gotovo smrt.

Uspeh na sodobnem bojišču zahteva učinkovito ravnotežje med ognjem in manevrom. Zanemarjanje enega na račun drugega povzroča, da je prvi ranljiv zaradi učinkov drugega (Johnson, 2000, str. 26). S transformacijo leta 2013 in ponovnim uvajanjem minometov $60 \mathrm{~mm}$ v pehotne čete je SV pridobila na sposobnosti ešaloniranja ognjev (glej prilogo 1). Treba pa je opozoriti na zmoto, ki je dolgo veljala, ne le v SV, temveč tudi v razpravah zunaj nje. Zmota je, da minomete $60 \mathrm{~mm}$ kot orožje za ognjeno podporo na najnižji taktični ravni lahko nadomestimo s sodobnimi avtomatskimi bombometi. Tega niso storili v nobeni pomembnejših oboroženih sil, vzrokov za to je več. Avtomatski bombometi so predvsem orožje za neposredno ognjeno delovanje, minometi pa za posredno. Avtomatski bombometi so okornejši in izkrcana pehota ${ }^{14}$ jih težje prenaša, njihovo strelivo ima manjši polmer onesposabljanja žive sile, zato je manj primerno za onemogočanje sovražnika, in ne nazadnje je krivulja leta granate bombometa položnejša ${ }^{15}$ ter zato manj primerna za delovanje na sovražnika v zaklonu ali za vertikalno oviro (Žabkar, 2007, str. 210 2014). To pa ne pomeni, da avtomatski bombometi nimajo svoje vloge na bojišču. Namen tega članka ni problematizirati uporabnosti avtomatskih bombometov kot

\footnotetext{
${ }^{13}$ Kot že rečeno, je zadnjih 125 m do cilja v napadu oz. ko se sovražnik približa na 125 m do naših obrambnih linij to v vsakem primeru prostor, ki ga je treba pokrivati s sistemi za neposredno delovanje.

${ }^{14}$ So pa odlični, ko so nameščeni na vozila.

15 Seveda je tu govora o merjenem delovanju na cilj.
} 
nadomestka za minomete $60 \mathrm{~mm}$, za zdaj naj zadostuje, da se avtomatski bombometi in minometi na bojišču dopolnjujejo, vsak sistem ima na njem svojo vlogo.

Če torej nadaljujemo, je danes v pehotni četi SV vod za ognjeno podporo z dvema minometoma $60 \mathrm{~mm}$ (Pišlar, 2015, str. 21), na brigadni ravni pa ima SV baterijo za ognjeno podporo, v kateri kombinira topove/havbice $155 \mathrm{~mm}$ in minomete $120 \mathrm{~mm}^{16}$ (Pišlar, 2014, str. 16). Na ravni baterije za ognjeno podporo je do osem minometov MN-9 $120 \mathrm{~mm}$ in do šest topov/havbic TN90 $155 \mathrm{~mm} .{ }^{17}$ Popolnjenost materialno-tehničnih sredstev in usposobljenost baterije za ognjeno podporo pa je slaba ${ }^{18}$. Avtorjeva ocena temelji na javno dostopnih podatkih o težavah s kadrovsko popolnjenostjo celotne SV, s pomanjkanjem finančnih sredstev za posodabljanje opreme, načrtovanih v SOPR, in izjav predsednika republike ter ministrov za obrambo v zadnjih petih letih.

Tu je treba opozoriti tudi na nesprejemljivost stališča, po katerem je mogoče havbice $105 \mathrm{~mm}$ nadomestiti z uporabo minometov $120 \mathrm{~mm}$. Kot pri vprašanjih, ali avtomatski bombomet ali minomet $60 \mathrm{~mm}$, gre tudi tu za dva oborožitvena sistema, ki imata na bojišču svojo posebno vlogo. Kljub temu da sodobni samovozni 120-milimetrski minometi dosegajo približno enake razdalje kot 105-milimetrske havbice, gre za bistveno razliko v namenu orožja. Minometi $120 \mathrm{~mm}$ ostajajo v vseh vojskah orožje, ki je na voljo poveljniku manevrskega elementa na ravni bataljona in je s svojo prilagodljivostjo ter odzivnostjo tam tudi najbolj uporabno. Havbice $105 \mathrm{~mm}$ pa ostajajo oborožitveni sistem, ki je na voljo poveljniku brigadne ravni za oblikovanje razmer na bojišču, skladno z njegovimi potrebami. Z vidika potrebe po ešaloniranju ognjev pa je nujnost obeh sistemov v formacijah povsem jasno opredeljena zgoraj.

SV ima v 15. polku vojaškega letalstva šolska bojna letala PC-9M, na katerih lahko kombinira različno oborožitev, od letalskih bomb Mk 81 in Mk 82 prek lanserjev nevodenih raket $70 \mathrm{~mm}$ do mitraljeza $12,7 \mathrm{~mm}$ (Slovenska vojska, http://www.slovenskavojska.si/).

Za sprejemanje zmogljivosti ognjev zavezništva ima SV v bateriji za ognjeno podporo, pa tudi v 15. polku vojaškega letalstva, usposobljene usmerjevalce združenih ognjev, ki so usposobljeni za usmerjanje različnih zavezniških oborožitvenih sistemov, tako letalskih kot helikopterskih, artilerijskih, minometnih in mornariških. SV je na področju usmerjanja združenih ognjev prevzela regionalno pobudo in začela ustanavljati regionalno šolo za te zmogljivosti (Oblak, 2015, str. 19).

\footnotetext{
${ }^{16}$ Edina podobna rešitev $v$ Natu, poznana avtorju, je francoska, pri kateri ravno tako $v$ artilerijskih enotah kombinirajo minometne $120 \mathrm{~mm}$ in artilerijske sisteme, a z jasno opredelitvijo, da je to storjeno zaradi usposabljanja in logistike. Minometi so sicer eksplicitno namenjeni pehotnim enotam (Armee de Terre, 2015, http//:www). V bojih so lastnice minometov $120 \mathrm{~mm}$ pehotne enote ranga bataljonov, artilerija pa je prisotna na ravni brigade in višje.

${ }^{17}$ Gre za domnevo. Številke so okvirne in so pridobljene na podlagi avtorjevih analiz razpoložljivih virov (predvsem revije SV). Uradni podatki o številu sistemov v enotah so namreč zaupni.

18 Gre za osebno oceno avtorja in ne uradno stališče pristojnih v SV. Mnenja pristojnih so izražena v različnih poročilih in zapisnikih analiz, ki sicer niso zaupne narave, a jih zaradi osebne prizadetosti posameznikov $v$ članku ne uporabljamo.
} 
V pehotnih enotah naj bi SV v obdobju od 2013 do 2018 oblikovala tudi zmogljivosti za civilno-vojaško sodelovanje, za potrebe bataljonske bojne skupine pa tudi modul za psihološko delovanje (SOPR, 2013, str. 14).

Po letu 2013 SV ponovno dobiva zmogljivosti za ešaloniranje ognjev, dejstvo pa je, da pri tem v organizacijskem smislu še vedno ostajajo precejšnje vrzeli, predvsem v minometni podpori, pa tudi podpori 105-milimetrskih havbic. Nekaterih zmogljivosti SV ne bo imela, saj presegajo njene okvire, marsikatero zmogljivost v ešaloniranju ognjev pa si bo lahko zagotovila tudi z delitvijo zavezniških zmogljivosti.

Ne moremo pa oceniti učinkovitosti sedanjih zmogljivosti sistemov ognjene podpore, saj SV zanje nima razvitih nikakršnih kazalnikov ${ }^{19}$. Tako ne moremo ne potrditi ne ovreči domneve, da je njena učinkovitost omejena in da enote niso dovolj usposobljene za uporabo sistemov ognjene podpore v konceptu združenega bojevanja rodov. Že našteta dejstva kažejo na to, da ima SV pri zagotavljanju učinkovite ognjene podpore še velike težave. Nimamo razloga, da bi domnevali drugače.

\section{UGOTOVITVE, POMEMBNE ZA SV}

Ko govorimo o zagotavljanju zaščite in varnosti vojaka na sodobnem bojišču, prevečkrat prevladuje mnenje, da ju dosežemo z boljšo individualno zaščito (uniforme, čelade, neprebojni jopiči) in oklepno zaščitenimi transportnimi sredstvi. Tudi če imajo ti sistemi pomembno vlogo, skladno s tipom operacije, v kateri so manevrske enote, pa ostaja dejstvo, da je največja stopnja varnosti za vojaka na manevrskem bojišču dosežena tako, da sovražnik nanj ne more delovati, kar na manevrskem bojišču dosežemo z uporabo sistemov ognjene podpore s konceptom ešaloniranja ognjev.

V Natu imajo vodilne države na voljo precejšnje zmogljivosti združene ognjene podpore, ki vse močno presegajo zmogljivosti, ki jih ima SV. SV tako v Natovih operacijah računa na to, da bo imela na voljo tudi zmogljivosti združene ognjene podpore iz drugih držav članic. Pri tem pa mora poskrbeti, da bo sposobna sprejemati učinke teh sistemov, pri čemer ima bistveno vlogo ustrezno usposobljen kader predvsem pripadniki enot za usmerjanje združenih ognjev in enot artilerijskih izvidnikov.

Nato je jasen v tem, da mora vsaka država članica najprej sama poskrbeti za svojo varnost in razvijati zmogljivosti zanjo (The North Atlantic Treaty, 1949). Kot je ugotovil Johnson v svoji študiji leta 2000, je treba zagotoviti dovolj sistemov za ognjeno podporo in na čim nižji taktični ravni. Ker je skladno z doktrino zavezništva

\footnotetext{
${ }^{19}$ Kot zanimivost lahko navedemo podatke za kopensko vojsko ZDA, ki je s kazalniki, ki jih uporabljajo v njihovih NTC (National Training Center - naša verzija se imenuje CBU), ugotovila, da so enote v NTC leta 1987 dosegale 60-odstotno učinkovitost ognjenih nalog, leta 2001 pa samo še 12-odstotno. Ti kazalniki so bili skrb vzbujajoči in vojska se je lotila temeljite analize vzrokov. Johnson v svoji študiji izpostavlja predvsem vprašanje neustrezne digitalizacije procesov (Johnson, 2000, str. 27 in 34-36).
} 
vod najnižja taktična raven, od katere se pričakuje samostojno izvajanje nalog, menimo, da mora SV na ravni voda zagotoviti minomete $60 \mathrm{~mm}$. Graditi mora sistem ognjev od ravni voda navzgor. Vod je tista taktična enota, ki lahko že samostojno opravlja nekatere naloge oziroma zavzema cilje na bojišču. $\mathrm{V}$ ta namen mora imeti poveljnik voda na voljo tudi ustrezne sisteme za posredno delovanje, kar so minometi $60 \mathrm{~mm}$. Ti bi omogočali poveljniku voda, da bi svoje oddelke lahko razmeroma varno pripeljal v položaj za odločilni juriš na objekt ali v položaj, iz katerega bi z ognjem iz orožja za neposredno delovanje lahko uničili sovražnika. SV bi morala na raven čete uvesti tudi minometne oddelke z minometi $81 \mathrm{~mm}$ (dve orožji) in ponovno tudi minometne vode z minometi $120 \mathrm{~mm}$ oziroma tako imenovane čete za ognjeno podporo na ravni polka. Minometni sistemi so po našem mnenju bistveni za uspeh manevra $\mathrm{SV}^{20}$. Uvedba minometov v obliki minometnih oddelkov (dve orožji) na raven voda in čete seveda pomeni precejšen izziv, tako materialni kot kadrovski in voditeljski. Izziv bi bil tudi zagotoviti ustrezno količino streliva na vodni ravni, predvsem pa njegovega transporta. Prav tako bi morali v sistemu izobraževanja častnikov na vstopni ravni šole za častnike zagotoviti razumevanje uporabe minometov na vodni ravni. Toda prednosti minometov na vodni in četni ravni bi odtehtale izzive.

Oborožene sile ZDA, Velike Britanije in Ruske federacije ne poznajo minometnih sistemov na ravni voda, toda na tej ravni lahko zagotavljajo ognje tudi z uporabo različnih zračnih, kopenskih in mornariških sistemov. In ko govorimo o njih, govorimo o bojnih helikopterjih, jurišnih letalih, manevrirnih raketah, vodenih artilerijskih in minometnih izstrelkih. Vseh teh pa SV nima in jih še nekaj časa ob sedanjih finančnih perspektivah ne bo imela.

Seveda predlagana rešitev (glej prilogo 2) pomeni izziv. Vztrajamo pa, da je $\mathrm{v}$ manevrskih enotah treba zagotoviti vse tri tipe minometov $(60 \mathrm{~mm}, 81 \mathrm{~mm}$ in $120 \mathrm{~mm}$ ), ker je potreba po njih jasno izražena. Mogoče so tudi druge rešitve, ki trenutno najbrž ne bi pomenile tolikšnega izziva (priloga 3). Minomete $60 \mathrm{~mm}$ bi lahko zadržali na četni ravni in njihovo število povečali na tri orožja v oddelku. Mogoča bi bila tudi kombinacija minometov $60 \mathrm{~mm}$ in $81 \mathrm{~mm}$ na četni ravni $\mathrm{v}$ večjem vodu za ognjeno podporo, ali pa kombinacija minometov $81 \mathrm{~mm}$ in $120 \mathrm{~mm}$ na polkovni ravni $\mathrm{v}$ tako imenovani četi za ognjeno podporo. Na polkovni ravni je pri minometih mogočih več rešitev. Prva je dvojna oborožitev v teh enotah, druga je enota minometov $81 \mathrm{~mm}$ in enota minometov $120 \mathrm{~mm}$, mogoča pa je tudi rešitev s tako imenovanimi vložnimi cevmi, s katerimi iz minometov $120 \mathrm{~mm}$ s posebnimi prilagoditvami lahko streljamo tudi mine kalibra $81 \mathrm{~mm}^{21}$ (Jones, 2008, str. 585 in 587). Minometov je na ravni polka težko preveč, je pa zaradi dovoljenih režimov ognja in maksimalne dovoljene obremenitve na posamezno orožje minimalna enota vod - torej štiri orožja. Sodobne vojske poznajo tudi rešitve s šestimi in osmimi

\footnotetext{
${ }^{20}$ Govorimo o delovanju SV zunaj zavezništva. Vsaka članica je najprej sama odgovorna za svojo varnost. Ko bodo enote SV delovale v formacijah zavezništva, seveda lahko računajo na zavezniške sisteme ZOGP.

${ }^{21}$ Gre za minomete ki jih uporablja kopenska vojska ZDA. Vložne cevi uporabljajo za usposabljanje zaradi viškov streliva $81 \mathrm{~mm}$.
} 
orožji v enotah bataljonske ravni. Pred transformacijo smo v SV poznali minometne čete na ravni bataljona s po dvema ognjenima vodoma, opremljenima z orožji kalibra $120 \mathrm{~mm}$ - skupaj osem orožij.

Minometni sistemi morajo biti pod nadzorom manevrskega poveljnika, to je najmanj poveljnika čete in polka, saj samo to zagotavlja njihovo razpoložljivost, ko jih manevrska enota potrebuje. Za uspeh koncepta ešaloniranja ognjev je ključna integracija minometnih sistemov $\mathrm{z}$ manevrsko enoto, ki jo zagotavljajo skupno usposabljanje ter učinkovito vodenje in upravljanje.

Na prvi pogled se sicer zdi, da bi lahko katerega izmed teh sistemov tudi izpustili in bi to vrzel pokrili z drugimi sistemi, $v$ resnici pa, kot smo pokazali zgoraj, to z vidika varnosti ni sprejemljivo. Zaradi količine in teže streliva minometnih sistemov pa je treba enote najnižje taktične ravni (čete in polki) opremiti z ustreznimi transportnimi sredstvi. To velja za manevrske enote lahke oziroma motorizirane pehote ${ }^{22}$, zračnodesantne in zračno-jurišne pehote, saj se pehota bojuje pretežno izkrcano.

Nekoliko drugače velja za enote gorske in oklepno-mehanizirane pehote ${ }^{23}$. Pri slednjih se taktične naloge rešujejo pretežno z vozili, pehota pa služi predvsem za zaščito teh vozil. Vozila oklepno-mehanizirane pehote imajo sisteme ognjene podpore za neposredno delovanje in stopnjo mobilnosti, ki jim omogoča večjo hitrost premika in ognjeno delovanje na večjih razdaljah. Poleg tega njihov temeljni način delovanja ni z izkrcano pehoto, ampak taktične naloge rešujejo predvsem z vozili. Zato potreba po podpori 60-milimetrskih minometov ni tako velika, potrebujejo pa več ognjene podpore sistemov za posredni ogenj večjega kalibra $\mathrm{z}$ daljšim dometom in boljšo mobilnostjo, torej samovozne sisteme (kolesne ali gosenične, odvisno od osnovnega tipa vozila). Po drugi strani je gorski polk manj gibljiv, transport v gorskem okolju je zelo omejen. Hkrati pa je gorski teren poseben bojni multiplikator za orožje ognjene podpore (Kuhar, 2008, str. 48). Tako je količino in kaliber orožja za posredne ognje v gorski enoti primerno omejiti na dva minometa $60 \mathrm{~mm}$ v četi in minomete $81 \mathrm{~mm}$ na ravni polka. Kar sicer ne pomeni, da so minometi $120 \mathrm{~mm}$ v gorski enoti neuporabni, a je treba prej ustrezno rešiti transport orožja in streliva.

Z vidika ešaloniranja ognjev je treba zagotoviti tudi več artilerije na ravni brigade. Ena baterija topov/havbic $155 \mathrm{~mm}$ lahko podpira en sam polk. Zato je treba zagotoviti vsaj dve bateriji z minimalno šestimi orožji na baterijo. Za SV pomeni

\footnotetext{
${ }^{22}$ Zavezništvo sicer pojma lahka pehota v svoji klasifikaciji različnih tipov pehote ne pozna. Pozna samo motorizirano pehoto, ki se bojuje pretežno v izkrcnem načinu, opremljena pa je z vozili, ki ji dajejo določeno stopnjo zaščite, mobilnosti in ognjene moči. Polki SV ne spadajo v to kategorijo pehote, saj v svoji sestavi nimajo ustreznih vozil, zato bi bila zanje še najustreznejša oznaka lahka pehota, za katero se domneva, da je zelo omejeno mobilna (noge vojakov) in nima oklepne zaščite vozil (če že ima vozila, so to tovornjaki ali neoklepna transportna vozila $4 \times 4$ ).

${ }^{23}$ SV ima kot enoto za gorsko bojevanje 132. pehotni polk, nima pa polka v vlogi mehanizirane enote. Pred transformacijo je bila ta vloga predvidena za 74. MOTB, zdaj pa je 72. brigada ( $v$ njeni sestavi je tudi 74 pehotni polk) nosilka oblikovanja zmogljivosti srednje bataljonske bojne skupine, ki naj bi bila zametek prihodnje mehanizirane bataljonske bojne skupne.
} 
artilerija brigadne ravni tudi najvišjo stopnjo artilerijske podpore, nad njo nima in ne bo imela zmogljivosti zagotavljanja artilerijskih ognjev. Predvsem je artilerija na brigadni ravni v SV tako imenovani fire provider, medtem ko so polki oziroma bataljonske bojne skupine uporabniki teh ognjev. Zato je treba razmisliti o čim močnejših zmogljivostih na tej ravni, morda celo z dvojno (105 mm in $155 \mathrm{~mm}$ ) oborožitvijo v baterijah, saj bodo te zmogljivosti zagotavljale ognje za vso SV tudi ob aktiviranju vojaške strateške rezerve. Z dvojno oborožitvijo bi pri oblikovanju razmer na bojišču poveljniku brigade omogočali večjo prilagodljivost njegovih manevrskih elementov, hkrati pa bi lahko ob aktiviranju vojaške strateške rezerve iz enega artilerijskega bataljona ustvarili dva. Predvsem pa ne smemo dovoliti, da bi artilerija postala sama sebi namen. ${ }^{24}$ Njena vloga mora biti najprej osredotočena na bližnjo ognjeno podporo manevrskim enotam in šele drugotno na zagotavljanje ognjev po globini. Transformacija leta 2012 je brigadam na taktični ravni dodelila artilerijske enote, ki jih poveljniki tudi vključujejo v usposabljanje manevrskih enot. Učinkovitost te integracije pa, kot že rečeno, ostaja vprašljiva.

Kombiniranje orožij 105 mm in 155 mm (po možnosti samovoznih na kolesnih vozilih) bi sicer povzročilo nekaj dodatnega logističnega bremena za enoto, toda $\mathrm{z}$ vidika ešaloniranja ognjev bi bila odločitev povsem smiselna. Navsezadnje zdaj v bateriji za ognjeno podporo združujemo minomete $120 \mathrm{~mm}$ in topove/havbice $155 \mathrm{~mm}$, tako da v smislu logističnega bremena zaradi streliva velikih razlik ne bi bilo.

V artilerijskih izvidniških enotah je treba zagotoviti usposobljeno moštvo, ki bo usklajevalo ognjeno podporo poveljnikom manevrskih enot in bo vodilo minometne in artilerijske ognje na cilje. Artilerijske izvidnike je treba usposobiti do ravni opazovalcev posredne ognjene podpore (angl. JFO) ${ }^{25}$, da bi lahko sodelovali v sistemu združene ognjene podpore SV in Nata. Artilerijski izvidniki na ravni opazovalcev posredne ognjene podpore bi tudi okrepili delo usmerjevalcev združenih ognjev. $\mathrm{V}$ ta namen bi bilo treba razširiti vlogo in naloge šole za usmerjevalce združenih ognjev v SV.

Te zahteve seveda pomenijo povečanje moštva v enotah s sistemi za ognjeno podporo. Po našem mnenju bi to lahko storili, saj rezerve v formacijah SV so. Priloga 3 je avtorjev predlog, za katerega je menja, da je trenutno uresničljiv ob predpostavki, da je pristop k spremembam formacij SV celovit. Dolgoročni cilj pa bi moral ostati tak, kot je zapisan v prilogi 2.

Alternativa minometnim in artilerijskih sistemom ognjene podpore je, da vrzel pokrivajo drugi sistemi ognjene podpore, pretežno letala in helikopterji z ustrezno oborožitvijo. Teh pa SV nima in jih z razvojnimi dokumenti niti ne predvideva.

\footnotetext{
${ }^{24}$ Na to je na primeru kopenske vojske ZDA opozoril tudi Johnson v svoji študiji, v kateri je ugotovil, da artileristi zavračajo vlogo »podpore kupca« in so precej raje »za volanom» (Johnson, 2000, str. 30).

${ }_{25}$ JFO = Joint Forward Observer ... v Natu označuje specialiste za usmerjanje predvsem artilerijskih in sekundarno tudi drugih sistemov ZOGP. Njihov status ni enak usmerjevalcem združenih ognjev, lahko pa dopolnjujejo njihovo delo in s tem bistveno pripomorejo $k$ njihovi učinkovitosti.
} 
PC-9M je šolsko bojno letalo z odličnimi karakteristikami in primerno oborožitvijo, a je bojno uporabno le v zelo omejenem obsegu in v situacijah, ko zračne grožnje ni in je grožnja sistemov zračne obrambe minimalna (Peacock, 2012, str. 430). To so samo protiuporniške operacije, kakršne poznamo iz Afganistana. Je pa seveda PC-9M odlično letalo za usposabljanje za uporabo združene ognjene podpore in ešaloniranje ognjev.

Za delovanje koncepta ešaloniranja ognjev je absolutno nujna tudi vzpostavitev ustreznega sistema vodenja in upravljanja sistemov ognjene podpore oziroma »združene« ognjene podpore. Ti sistemi so danes digitalizirani, kar omogoča večjo odzivnost in načeloma zmanjšuje potrebo po moštvu. Vendar pa se je digitalizacije sistema upravljanja in vodenja sistemov ognjene podpore treba lotiti zelo previdno. $\mathrm{Na}$ pasti digitalizacije je zelo nazorno opozoril podpolkovnik ameriške kopenske vojske Johnson, R. C., ki je ugotovil, da je digitalizacija sistema vodenja in upravljanja pravzaprav zmanjšala učinkovitost artilerijskih enot pri zagotavljanju bližnje podpore manevrskim enotam. Digitalizacija je namreč povzročila centralizacijo odločanja in mikromenedžment, namesto da bi omogočila decentralizacijo in prepuščala pobudo podrejenim in tako povečala odzivnost tam, kjer je najbolj potrebna - v bližinskem boju (Johnson, 2000, str. 34-36).

Tudi elementi vplivanja imajo svojo vlogo pri ešaloniranju ognjev za manevrske enote SV. Odvisno od tipa operacije lahko elementi civilno-vojaškega in psihološkega delovanja ter drugi različno učinkovito vplivajo na sovražnika in tako zmanjšajo izpostavljenost pripadnikov SV njegovemu ognju. SV mora razmisliti o vzpostavitvi formacijskih enot za elemente vplivanja, predvsem civilno-vojaškega in psihološkega delovanja.

Med ključnimi nalogami za delovanje ešaloniranja ognjev, ki SV še čakajo, pa sta sprejetje ustreznih doktrinarnih in pravnoformalnih podlag ter organizacija ustreznega usposabljanja enot in predvsem poveljujočega kadra. Za delovanje koncepta ešaloniranja ognjev je nujno razumevanje razdalje sprejemljivega tveganja, minimalne varne razdalje in bližine lastnih sil ter teorije, ki je za njimi. Stanag 7144 je v veljavi v SV, a poleg razlage pojmov razdalja sprejemljivega tveganja in bližina lastnih sil ter navedbe nekaj primerov razdalj ne vsebuje nekaterih drugih pomembnih informacij za delovanje koncepta ešaloniranja ognjev. Predvsem manjkajo definicije in opredelitve minimalnih varnih razdalj za posamezne oborožitvene sisteme. ${ }^{26}$ To je tudi razumljivo, saj Stanagi pomenijo minimalni dogovorjeni skupni standard. Stvar posamezne članice pa je, da podrobneje opredeli strokovno-tehnične podrobnosti skladno s skupnimi standardi, svojimi potrebami in omejitvami. SV ima pri tem dve možnosti. Prva je, da razvije svojo metodologijo določanja teh razdalj in jih uvede v uporabo. Druga pa je, da se ozre po dostopnih publikacijah zaveznic, ki obravnavajo sisteme $\mathrm{z}$ enakimi ali podobnimi značilnostmi in jih formalno uvede $\mathrm{v}$ uporabo $\mathrm{v} \mathrm{SV}$. Po avtorjevem mnenju je JFIRE publikacija (ALSA-center), ki bi povsem zadoščala

${ }^{26}$ Minimalne varne razdalje so nujne za usposabljanje z ostrim strelivom $v$ SV. 
$\mathrm{SV}$, tako pri samostojnem delovanju kot pri delovanju v zavezništvu. Z aktom ministra bi tako publikacijo lahko uvedli v uporabo v SV, skupaj z morebitnimi strokovnimi pripombami ali omejitvami pri njeni uporabi. To je nujno tudi zaradi pravne varnosti poveljujočih in pripadnikov, ki načrtujejo in izvajajo ognje v podpori manevru enot SV.

Najpomembnejša za razumevanje delovanja koncepta ešaloniranja ognjev in sistemov za posredni ogenj v združeni ognjeni podpori SV in Nata pa sta izobraževanje in usposabljanje. Ešaloniranje ognjev je treba najprej poučevati na vseh častniških šolah nad ravnjo voda in na vseh podčastniških šolah nad ravnjo četnega podčastnika. SV tudi že izvaja mednarodno uveljavljeno vajo Adriatic Strike, ki je namenjena predvsem usmerjevalcem združenih ognjev. S tem je dokazala, da je vaja lahko odlična priložnost za usposabljanje manevrskih elementov iz uporabe sistemov ognjene podpore (tako SV kot zavezniške).

Vsekakor pa mora pravilno ešaloniranje razpoložljivih ognjev v podpori manevru postati v SV pogoj za pozitivno oceno izvedbe katere koli taktične vaje z bojnim streljanjem nad ravnjo oddelka.

\section{Literatura}

1. ATTP 3-21.90, 2011. Tactical Employment of Mortars. HQ, Department of the Army, Washington, $D C$.

2. Brinc in drugi, 2006. Angleško-slovenski vojaški terminološki slovar. PDRIU http://intra. mors.si/index.php?id=1718 (13. 6. 2015).

3. Državni zbor Republike Slovenije, 2004. Zakon o obrambi (uradno prečiščeno besedilo) (ZObr-UPB1). Ljubljana.

4. FKSM 71-8, 2010. Armor/Cavalry reference data; Brigade combat teams. US Army Armor Center, Fort Knox, KY.

5. FM 3-21.10, 2006. The Infantry Company. Headquarters Department of the Army, Washington, $D C$.

6. Furlan, B. (in drugi), 2006. Vojaška doktrina. Ljubljana: Defensor, d. o. o.

7. Gažević, N., in drugi, 1971. Vojna enciklopedija (drugo izdanje) - 2 Brdo-Foa. Izdanje redakcije vojne enciklopedije, Beograd.

8. Gažević, N., in drugi, 1973. Vojna enciklopedija (drugo izdanje) - 6 Nauloh-Podvodni. Izdanje redakcije vojne enciklopedije, Beograd.

9. Gažević, N., in drugi, 1975. Vojna enciklopedija (drugo izdanje) - 10 Tirani-Žužul. Izdanje redakcije vojne enciklopedije, Beograd.

10. Garb in drugi, 2009. Razlagalni vojaški slovar. http://intra.mors.si/index.php?id=1718 (13. 6. 2015).

11. Hacket, J., 2015. The Military balance; the annual assessment of global military capabilities and defence economics 2015. The International Institute for Strategic Studies, London, UK.

12. Hayes, T. R., 1996. Dismounted Infantry Movement Rate Study. Simulation Technologies, Inc., Dayton, Ohio.

13. JFIRE, 2012. Multi-service tactics, tehniques, and procedures for the joint application of firepower. Air Land Sea Aplication Center, ZDA.

14. Jones, R. D., in Leland, N., 2008. Jane's Infantry Weapons 2008-2009. Biddles Ltd., Kings Lynn, Great Britan. 
15. Johnson, R. C., 2000. Fighting with fires: Decentralised Control to Increase Responsivness. School of Advanced Military Studies, USA CGSC, Forth Leavenworth, Kansas.

16. Kolednik, A., 2015. Zakaj hočejo Hrvati imeti raketometes 300-kilometrskim dosegom? (video). Planet Siol.net http://www.siol.net/novice/svet/2015/10/hrvaska_zeli_imeti_ raketomete.aspx (13. 10. 2015).

17. Kuhar, M., 2008. Taktika bojevanja v gorah-priročnik. MORS, Ljubljana, 2008.

18. NATO, 2013. AAP-06 Edition 2013, NATO glossary of terms and definitions (English and French). NATO Stardandisation Agency.

19. NATO, 2011. AartyP-5(A) Nato Indirect Fire Systems Tactical Doctrine. NATO Stardandisation Agency.

20. Osterman, A., 2015. Koncept Združene Ognjene Podpore SV. GŠSV, Ljubljana.

21. Oblak, N., 2015. Šola za usmerjevalce združenega ognja. Revija SV, 5. maj 2015. Ljubljana: $M O R S$.

22. Oblak, N., 2015. Adriatic Strike 2015. Revija SV, 6. junij 2015. Ljubljana: MO RS.

23. Peacock, L., in von Rosenback, A., 2012. IHS Jane's World Air forces 2012 - issue thrtiyfive. IHS Global Limited, UK.

24. Pišlar, M., 2015. Artilerija 72. Brigade na usposabljanju za vojaško evidenčne dolžnosti. Revija SV, 1. januar 2014. Ljubljana: MO RS

25. Pišlar, M., 2015. SV bogatejša za 46 artilercev. Revija SV, 12. december 2014. Ljubljana. MO RS.

26. Pišlar, M., 2015. Streljali z minometi 60 milimetrov. Revija SV, 9. september 2015. Ljubljana: $M O R S$.

27. Stanimirovič, M., 1973. Minobacač $60 \mathrm{~mm}$ M57 sa tablicama gađanja. SSNO, Vojna štamparija, Beograd.

28. Vlada RS, 2013. Srednjeročni obrambni program Republike Slovenije 2013 - 2018. Ljubljana: št. 80300-1/2013/3 z dne 1. 2. 2013.

29. Žabkar, A., 2007. Pehotna oborožitev in oprema - stanje in smeri razvoja. Založba Defensor, Ljubljana.

30. Armee de Terre, Organisation des forces, Artillerie http://www.defense.gouv.fr/terre/ presentation/organisation-des-forces/artillerie/40e-regiment-d-artillerie (16. 10. 2015).

31. Otmann, S., New Russian Brigade TO\&E; http://defense-and-freedom.blogspot. com/2009/10/new-russian-brigade-to.html (23. 6. 2015).

32. Pilatus PC-9M Hudournik, http://www.slovenskavojska.si/oborozitev-in-oprema/letala-inhelikopterji/pilatus-pc-9m-hudournik/ (16. 10. 2015).

33. The British Army, Armoured Infantry Brigade Organisation http://www.armedforces. co.uk/army/listings/l0013.html (23. 6. 2015).

34. The British Army, Battlegroups And Company Groups/Task Group http://www. armedforces.co.uk/army/listings/l0014.html (23. 6. 2015).

35. The British Army, Heavy Protected Mobility Battalion http://www.armedforces.co.uk/ army/listings/l0030.html (23. 6. 2015).

36. The British Army, Light Protected Mobility Battalion http://www.armedforces.co.uk/army/ listings/l0031.html (23. 6. 2015).

37. The North Atlantic Teraty na http://www.nato.int/nato_static/assets/pdf/stock publications/20120822_nato_treaty_en_light_2009.pdf (16.1. 2015). 


\section{RAZVOJ POJMA IN KONCEPTA CIVILNO- VOJAŠKEGA SODELOVANJA IN USKLAJEVANJA V MIROVNIH OPERACIJAH}

\section{DEVELOPMENT OF THE TERM AND THE CONCEPT OF CIVIL-MILITARY CO-OPERATION AND CO- ORDINATION IN PEACE OPERATIONS}

Povzetek Civilno-vojaško sodelovanje (Civil-military co-operation - CIMIC) je v sodobnih mirovnih operacijah pomemben del aktivnosti. Koncept se je razvil iz potrebe po medsebojnem sodelovanju civilnih in vojaških akterjev in je na začetku deloval kot kolektivni termin. Nanašal se je na vse vrste interakcij in stikov med civilnimi organizacijami ter vojsko. Toda povečevanje stopnje interakcije med akterji in rast pomena civilno-vojaškega sodelovanja sta prinesla s seboj razvoj različnih konceptov pod istim izrazom in kratico CIMIC (slov. CVS), kar je vodilo v zmedo in nesporazume. Prispevek predstavlja razvoj koncepta ter značilnosti razvoja konceptov civilno-vojaškega sodelovanja različnih akterjev mirovnih operacij, kot so Nato, Organizacija združenih narodov in njene agencije, Evropska unija ter nekatere humanitarne organizacije. Njegov namen je prispevati k razumevanju različnosti konceptov civilno-vojaškega sodelovanja in s tem k manjšanju možnosti morebitnih sporov med akterji mirovnih operacij.

Ključne besede

Abstract

\section{Civilno-vojaško sodelovanje, CIMIC, CVS, civilno-vojaško usklajevanje.}

In modern peace operations, civil-military cooperation (CIMIC) constitutes an important part of activities. The concept has developed from the need for mutual cooperation of civil and military actors and was initially used as a collective term referring to all types of interaction and relations between civil organizations and the military. However, the increased level of interaction between the actors, and the growing importance of civil-military cooperation have brought along the development of different concepts under the same term and acronym CIMIC, which has resulted in confusion and misunderstanding. The article presents the development of the concept and the characteristics of concept development in civil-military cooperation by different actors of peace operations, such as NATO, the United Nations Organization and its agencies, the European Union and some humanitarian organizations. 
Its aim is to develop the understanding of different civil-military cooperation concepts and consequently reduce the possibility of disputes between peace operations actors.

\section{Key words Civil-military cooperation, CIMIC, civil-military coordination.}

Uvod Sodobne mirovne operacije, ki po definiciji Ramsbothama in Woodhousa (1999, str. xix) vključujejo operacije ohranjanja ali vsiljevanja miru in druge vojaške operacije $\mathrm{v}$ kontekstu političnih in diplomatskih prizadevanj za ustanovitev ter ohranjanje miru, označujeta izrazita večdimenzionalnost in težnja po vse bolj integriranem delovanju vojaških in različnih civilnih akterjev. Zaradi različnih mandatov, narave delovanja in organizacijske kulture ter še drugih razlik med vojaškimi silami in civilnimi akterji v mirovnih operacijah je sodelovanje med njimi polno najrazličnejših dilem, izzivov, težav, kar se kaže že na pojmovni ravni. Kot ugotavlja Rehse $(2004,24)$, je vse od začetka 90. let prejšnjega stoletja civilnovojaško sodelovanje (Civil-Military Cooperation) oziroma njegova kratica CIMIC (v Sloveniji se uveljavlja kratica CVS) kontroverzen termin v vroči razpravi v civilni, humanitarni in vojaški skupnosti, kadar je šlo za njihove medsebojne odnose. V tem času se je termin razvijal od kolektivnega termina za vsakršne civilno-vojaške interakcije in stike, pogosto za menedžment civilno-vojaške prepletenosti (zlasti še med vojsko in humanitarnimi organizacijami), do termina vojaška doktrina.

Razprava o civilno-vojaškem sodelovanju prinaša kar nekaj težav. V pregledu in analizi tega sodelovanja leta 2004 Rehse ugotavlja, da do takrat še ni bilo splošno sprejete in usklajene definicije tega termina. Različni akterji govorijo o civilnovojaškem sodelovanju v različnih kontekstih, z različnimi pomeni in različnimi interpretacijami. Na začetku je civilno-vojaško sodelovanje sicer delovalo kot kolektivni pojem in se je nanašalo na vse vrste interakcij ter stikov med civilnimi organizacijami in vojsko. Oboji so ga jemali kot oznako svojih akcij do druge strani. Toda povečevanje stopnje interakcije med akterji in rast pomena civilno-vojaškega sodelovanja sta s seboj prinesla različne koncepte, ki jih je združeval enak izraz (CIMIC), kar je vodilo v zmedo in nesporazume. Mednarodna skupnost je zato uvedla bolj raznolike pristope $\mathrm{k}$ terminu. Med pomembnejšimi dejavniki tega procesa je bilo povečano sodelovanje Nata v mirovnih operacijah. Delovanje te zveze na Balkanu je povečalo potrebo po nekakšni politiki civilno-vojaškega sodelovanja oziroma doktrini Nata. Nato je tako razvil procedure in vojaško doktrino, po katerih je civilno-vojaško sodelovanje postalo v vojaškem besednjaku dobro opredeljen in specifičen pojem, s tem pa je Nato izraz (mislimo še posebej na kratico CIMIC) pravzaprav prevzel in ga navezal na svoje razumevanje tega sodelovanja. Posledično so druge organizacije za svoje koncepte civilno-vojaškega sodelovanja, da bi jih ločile od Natovega, morale začeti razvijati nove pojme. Tako je na primer Urad Združenih narodov za usklajevanje humanitarnih zadev (United Nations Office for Coordination of Humanitarian Affairs - UNOCHA) za svoje programe, ki so pred letom 2001 potekali pod oznako CIMIC, predstavil okrajšavo UN CMCoorD (Rehse, 2004, str. 15-16). CIMIC moramo sicer še vedno razumeti tudi v širšem oziroma 
splošnem pomenu, torej kot vsake vrste interakcijo med civilnimi in vojaškimi subjekti, hkrati pa se zavedati, da je tudi izraz Natovih politike in doktrine civilnovojaškega sodelovanja. Ob uporabi izraza pa je seveda nujno, da ločimo oboje in poudarimo, na katero razumevanje se izraz CIMIC nanaša (po Rehse, 2004, str. 16).

Prispevek je v osnovni obliki nastal v projektu Vloga države pri vključevanju civilnih subjektov v mednarodne operacije na kriznih območjih, ki je v letih 2007-2008 potekal v okviru Ciljnega raziskovalnega programa Znanost za varnost in mir 20062010, v pripravi za objavo v reviji Sodobni vojaški izzivi pa je bil dopolnjen in posodobljen. ${ }^{1}$ Namenjen je predstavitvi nastanka pojma in prakse civilno-vojaškega sodelovanja ter smeri razvoja njegovega koncepta pri različnih organizacijah. S tem želimo prispevati ne samo $\mathrm{k}$ razumevanju naslovnega pojma, temveč tudi $\mathrm{k}$ razumevanju razlik oziroma posebnosti civilno-vojaškega sodelovanja v mirovnih operacijah pri različnih organizacijah.

\section{NATO IN CIMIC}

Za razvoj Natove doktrine civilno-vojaškega sodelovanja sta bistvenega pomena misiji Iforja in Sforja v Bosni in Hercegovini. Z delovanjem Iforja, ki je imel nalogo uveljaviti vojaške vidike daytonskega mirovnega sporazuma, je bila približno $\mathrm{v}$ letu dni dosežena takšna stopnja varnosti v okolju, da so se lahko začeli uveljavljati civilni vidiki sporazuma in so lahko začele delo nevojaške organizacije. Ifor se je v tem času aktivno vključeval v humanitarno podporo, volitve, dolgoročne projekte in rekonstrukcijo infrastrukture (po Rehse, 2004, str. 27). Kot primer sodelovanja vojske in civilnih organizacij lahko navedemo tudi sodelovanje Sforja in Urada Visokega komisarja Združenih narodov za begunce (UNHCR). Častniki za zvezo in vojaški svetovalci so bili skupaj $\mathrm{v}$ pisarnah tako na regionalnih kot lokalnih ravneh. Vzrok tega sodelovanja je v pomenu, ki ga je UNHCR pripisoval varnosti pri svojih aktivnostih, zlasti pri podpori vračanju beguncev in razseljenih oseb. Mandat Sforja je ne nazadnje vključeval tudi sodelovanje pri uveljavljanju civilnih vidikov mirovnega sporazuma (Studer, 2001, str. 377). Mednarodno delovanje v Bosni in Hercegovini po letu 1995 je torej nekakšna zibelka Natovega civilno-vojaškega sodelovanja.

Razvoj Natovega civilno-vojaškega sodelovanja lahko na kratko pogledamo z analizo, ki jo je opravila Logar Kelc. Ifor je v Bosni in Hercegovini s svojim delovanjem do leta 1996 vzpostavil varno okolje. »To je bilo bistveno za implementacijo civilnih aspektov mirovnega dogovora. Nevojaške organizacije so lahko začele $\mathrm{z}$ delom. Istočasno pa se je Ifor vedno bolj vključeval v humanitarno podporo, volitve na državni ravni, dolgoročne projekte in rekonstrukcijo infrastrukture.« Ta preobrat $\mathrm{v}$ nalogah Iforja je pokazal potrebo po doktrini o civilno-vojaškem sodelovanju kot tudi po posebnih silah, ki bi bile v pomoč Natovim poveljnikom v operacijah v podporo miru. Kmalu po začetku misije Ifor

1 Avtorica se zahvaljuje recenzentom za koristne strokovne napotke. 
je bil v poveljstvu SHAPE ${ }^{2}$ ustanovljen oddelek za civilno-vojaško sodelovanje. Ta je bil odgovoren za zahteve urjenja in pripravo učnih načrtov. Leta 1997 je Vojaški odbor sestavil dokument MC-411 Nato CIMIC. V začetku leta 1998 pa je SHAPE razvil direktivo CIMIC 2000, ki je od tedaj predstavljala podlago za vse nadaljnje načrte in izvedbe.

Kadrovska struktura sil za civilno-vojaško sodelovanje (Civil-Military Task ForceCMTF) je bila še en dejavnik, ki je prispeval $k$ razvoju Natove doktrine o civilnovojaškem sodelovanju. CMTF so bile oblikovane za podporo IFOR-ju in SFOR-ju v Bosni in Hercegovini, večino osebja pa so prispevale Združene države Amerike. Ker pa so hotele biti evropske članice bolj vključene v'novi' Nato, je bilo to neravnovesje treba odpraviti. Cilj je bil 50-odstotna udeležba drugih članic poleg ZDA. Vendar pa je evropskim članicam primanjkovalo usposobljenega osebja, zato je poveljstvo SHAPE začelo izvajati usposabljanje za civilno-vojaško sodelovanje in kmalu se je CMTF prestrukturiral v CIMIC Task Force (CIMIC TF), v katerem so imeli Evropejci znatno večji delež osebja. Strateški koncept iz leta 1999 se eksplicitno nanaša na civilno-vojaško sodelovanje in poudarja pomen le-tega za uspešno dokončanje vojaške operacije - interakcija med zavezniškimi silami in civilnim okoljem (tako vladnim kot nevladnim), v katerem delujejo, je ključna za uspeh operacije. Civilnovojaško sodelovanje je $v$ medsebojni odvisnosti: vojaška sredstva so vedno bolj namenjena le za podporo civilnim oblastem, hkrati pa je civilna podpora vojaški operaciji pomembna za logistiko, komunikacijo, medicinsko oskrbo in javne zadeve. Sodelovanje med zavezniškimi vojaškimi in civilnimi telesi bo zato ostalo bistvenega pomena (Logar Kelc, 2007, str. 20-22).

Izkušnje iz Bosne in Hercegovine torej kažejo, kot ugotavlja Zandee (1999), da se je žarišče civilno-vojaškega sodelovanja po koncu hladne vojne premaknilo z načrtovanja civilne podpore za vojaške operacije na zagotavljanje vojaške podpore za civilne operacije graditve miru. Avtor tudi pravi, da:

/.../ vloge CIMIC-a ne smemo ne precenjevati in ne podcenjevati. Prvič, CIMIC ne nadomešča civilne implementacije, ampak podpira civilne napore. Ima pa vendarle bistveno vlogo pri zapolnjevanju praznega prostora, dokler strani in civilne organizacije niso v položaju, ko lahko same peljejo naprej mirovni proces. Drugič, CIMIC predstavlja veliko več kot le preprosto gradnjo šol in bolnišnic ter lokalnih skupnosti, čeprav so to, jasno, pomembne dejavnosti in prispevajo $k$ nastajanju lokalne podpore vojaškim enotam. CIMIC ima ključno vlogo v skoraj vsakem vidiku civilne implementacije, pa bodisi gre za vračanje beguncev in razseljenih oseb, ponovno vzpostavljanje reda in miru, ekonomsko rekonstrukcijo, obnovo infrastrukture, organiziranje volitev ali ustanavljanje novih institucij. Je cement, ki drži skupaj zidake za mir. In še, ko se postavijo prihodnje zahteve za CIMIC, ne smemo upoštevati le izkušenj iz IFOR-ja oziroma SFOR-ja. Vsak konflikt ima namreč specifičen kontekst in mirovni sporazumi so narejeni od primera do primera. Ne

2 SHAPE - Supreme Headquarters Allied Powers Europe. Vrhovno poveljstvo sil zavezništva v Evropi. 
glede na to pa je treba $v$ vsaki pokonfliktni mirovni operaciji izvajati vrsto podobnih dejavnosti s podporo vojske. Obstaja jasna potreba po skupnih načrtih glede CIMIC-a in njegove strukture, toda vse mora biti fleksibilno, da se lahko prilagodi neposrednim razmeram (Zandee, 1999).

Natova definicija civilno-vojaškega sodelovanja je: usklajevanje in sodelovanje (koordinacija in kooperacija) v podporo misiji med poveljnikom Nata in civilnimi akterji, vključno $\mathrm{z}$ nacionalnim prebivalstvom in lokalnimi oblastmi ter $\mathrm{z}$ mednarodnimi, nacionalnimi in nevladnimi organizacijami ter agencijami (po AJP-9 2003, AJP-3.4.9. 2013 in po Natovi vojaški politiki o civilno-vojaškem sodelovanjuMilitary Council Doctrine-MC 411/1). Namen in cilj civilno-vojaškega sodelovanja je interakcija med vojaškimi in civilnimi akterji v okolju v podporo načrtom vojaškega poveljnika. V idealnih razmerah bodo vsi akterji delovali za skupen cilj, kadar pa to ne bo mogoče, bo ta interakcija zagotavljala, da bodo vsi načrti usklajeni, kolikor bo pač mogoče. S tem se bodo, kolikor je mogoče, zmanjšali vmešavanje in nehoteni spori med akterji (AJP-3.4.9., str. 2-1). J9 - oddelek za CIMIC - je odgovoren za zagotavljanje celovitih usmeritev ter usklajevanje in svetovanje Natovemu strateškemu poveljstvu za operacije (Allied Command Operations - ACO) (NATO SHAPE - Civil-Military Cooperation). V organizacijskem smislu moramo omeniti še Večnacionalno skupino za civilno-vojaško sodelovanje, ki je Natova specializirana enota za civilno-vojaško sodelovanje na operativni in taktični ravni, ter Center odličnosti za civilno-vojaško sodelovanje (CCOE), ki ne spada v poveljevalno shemo Nata, ukvarja pa se s svetovanjem, usposabljanjem in izobraževanjem, razvojem doktrin in konceptov ter procesom učenja iz izkušenj (Mazurkiewicz 2014, str. 133; Multinational CIMIC Group; CIMIC Centre of Excellence).

Rehse (2004, str. 30) glede na opredelitev civilno-vojaškega sodelovanja v Natovih dokumentih ugotavlja, da je CIMIC taktična doktrina in ne strategija. Uporablja se kot instrument za dosego ciljev vojaške operacije. Mustonen (2008, str. 21) pravi, da Natova doktrina predstavlja CIMIC predvsem kot orodje poveljnika in taktično doktrino, ne kot strategijo za usklajevanje.

Za CIMIC se označuje tista pomoč, ki je nujna za podporo vojaškim operacijam. Prek verige poveljevanja pa se izvaja le, če pri tem sodeluje primerna organizacija, na primer Organizacija združenih narodov (OZN). Natova politika civilno-vojaškega sodelovanja torej opredeljuje vojaško vključevanje v naloge, ki so nevojaške narave in so običajno pod odgovornostjo mandatne civilne oblasti. Dodatna pomoč, ki ni del vojaškega mandata z vojaško-političnimi cilji, se ne razume kot CIMIC (Rehse, 2004, str. 31-32).

Natova doktrina civilno-vojaškega sodelovanja predvideva civilno-vojaško sodelovanje $\mathrm{v}$ treh stopnjah življenjskega ciklusa operacije. V predoperacijski fazi njegovo osebje pomaga silam pri pripravah na civilne razmere operacije. Med operacijo zagotavlja civilno-vojaško sodelovanje, vzpostavljanje in ohranjanje odnosov s civilnimi telesi za podporo delu poveljnika. V tranzicijskem obdobju 
pa pomaga pri predaji aktivnosti novim oblastem (Rehse, 2004, str. 33). Naloge Natovega CIMIC-a obsegajo tri področja delovanja, in sicer civilno-vojaške zveze ${ }^{3}$ (nujno usklajevanje s civilnimi telesi), podporo civilnemu okolju (interakcija s civilnimi telesi med operacijo) in podporo silam (zadeve, ki zahtevajo civilno podporo vojski) (Rehse, 2004, str. 33-34).

Natova doktrina civilno-vojaškega sodelovanja v splošnem poudarja, da se zavezništvo ukvarja izključno z nalogami, ki so povezane z varnostjo. Če je treba in če je skladno z operativnim načrtom ter mandatom civilnih oblasti, se lahko podprejo tudi civilne naloge, ki jih izvaja primerna civilna avtoriteta (nima pa CIMIC nadzora nad civilnimi telesi) ${ }^{4}$ (Rehse, 2004, str. 36, 39). Ne nazadnje je civilno-vojaško sodelovanje tudi del Natovega celovitega pristopa, ki je usmerjen $\mathrm{v}$ doseganje enotnosti cilja in ne toliko enotnosti prizadevanj ali enotnosti poveljevanja (glej Mazurkiewicz, 2014, str. 131).

Kljub novim dokumentom (kot je AJP-3.4.9.) se zdi, da vsebina Natovega civilno-vojaškega sodelovanja ostaja podobna, se je pa področje v zadnjih letih institucionalno razvilo. Že omenjena Večnacionalna skupina za civilno-vojaško sodelovanje (Multinational CIMIC Group - MNCG) ${ }^{5}$ oziroma poveljstvo za CIMIC je bilo v Natu uradno ustanovljeno aprila 2009 (SHAPE News Release, 5. maj 2009). Njegova predhodnica, CIMIC skupina jug, je bila ustanovljena v Motta di Livenza v Italiji že leta 2002 (Mazurkiewicz, 2014, str. 133-134).

\section{ORGANIZACIJA ZDRUŽENIH NARODOV TER CIVILNO-VOJAŠKO SODELOVANJE IN USKLAJEVANJE}

Rehse (2004) v analizi konceptov, definicij in prakse civilno-vojaškega sodelovanja ugotavlja, da se je po letu 1991 začel značaj operacij OZN za ohranjanje miru precej spreminjati. Čeprav je vojska še vedno bistven del mirovnih sil, se povečuje število civilistov, ki delajo skupaj z vojaki. Operacije so namreč postale celovitejše, OZN uporablja termin večdimenzionalne mirovne operacije, ki vključujejo poleg vojaških še vrsto humanitarnih vidikov. Drugi razlog je širitev humanitarnega vidika in naraščanja števila različnih agencij (tako agencije OZN kot nevladne) za razdeljevanje pomoči v teh operacijah. Vzrok je tudi v tem, da se je vojska približala

\footnotetext{
Civil-Military Liaison.

${ }_{4}$ Doktrina sicer predvideva nekaj izjemnih okoliščin, v katerih se od vojske lahko zahteva, da prevzame tudi tiste naloge, ki so običajno v odgovornosti civilnih oblasti. Govorimo o okoliščinah, ko neko civilno telo ni prisotno ali pa je nesposobno izpolnjevati svoj mandat ipd. (dokler to civilno telo ni pripravljeno na prevzem nalog), kadar gre za življenjsko ogroženost lokalnega prebivalstva ali za dolgoročno stabilnost družbe (po Rehse, 2004, 37).

Memorandum of Understanding, ki je uvedel civilno-vojaško sodelovanje na ravni poveljstva, so 28. aprila 2009 podpisali predstavniki petih držav članic Nata, in sicer Grčije, Madžarske, Italije, Portugalske in Romunije, ter SHAPE. S tem se je leta 2002 ustanovljena skupina jug (sedež v Motta di Livenza v Italiji), v kateri so sodelovale Grčija, Madžarska, Portugalska in Romunija, leta 2009 pa sta sile poverili tudi Bolgarija in Slovenija, preoblikovala v Večnacionalno skupino za civilno-vojaško sodelovanje (SHAPE News Release, 5. maj 2009).
} 
civilnim vidikom misije, s čimer so se povečali stiki med vojsko in civilnimi akterji, odnosi med njimi pa postajajo vse pomembnejši.

Rehse (2004, str. 13) tudi ugotavlja, da se je po polomih v mirovnih operacijah v Somaliji, Ruandi ter Bosni in Hercegovini (primer Srebrenice) v 90. letih prejšnjega stoletja spremenil odnos članic OZN. Niso bile več pri volji, da bi se z operacijami lotevale bistvenih vzrokov konfliktov, temveč so se nagibale k uporabi mešanice humanitarnih in političnih mandatov - kot nadomestilo vojaških in političnih akcij za končanje konfliktov. ${ }^{6}$

OZN je namesto civilno-vojaškega sodelovanja začela razvijati koncept civilnovojaškega usklajevanja (oziroma civilno-vojaško koordinacijo), Urad ZN za usklajevanje humanitarnih zadev (UN Office for the Coordination of Humanitarian Affairs - OCHA) za označevanje te aktivnosti uporablja kratico CMCoord (CivilMilitary Co-ordination). Za oznako civilno-vojaškega usklajevanja oziroma koordinacije se uporablja tudi kratica CMCO (po Mustonen, 2008, str. 21). V praksi najdemo poleg CIMIC in CMCoord še precej drugih poimenovanj in okrajšav oziroma kratic - CIMCO, CMO, CMA, CML, CMLO ipd. CIMIC povezujemo z Natom, poznajo ga tudi v večini evropskih držav ter v Kanadi, Avstraliji ter na Novi Zelandiji. Evropska unija razvija nov koncept civilno-vojaškega usklajevanja (angl. CIMCO), Združene države Amerike (ZDA) pa imajo svojo doktrino in terminologijo ter uporabljajo termin civilno-vojaške operacije (angl. CMO) (Coning, 2007, str. 4-5).

Coning (2007, str. 5) ugotavlja, da se mirovne operacije OZN razlikujejo od večine mirovnih in stabilizacijskih operacij Nata, Evropske unije ter koalicij, in sicer v dvojem. Prvič, zanje je značilno, da temeljijo na konsenzu - da se vzpostavijo po premirju ali podpisu mirovnega sporazuma na zahtevo strani v konfliktu in za podporo pri uveljavljanju mirovnega sporazuma. In drugič, vojaška sila je le del integriranih mirovnih misij pod celovitim civilnim vodenjem in je torej le nekako vstavljena v misijo OZN. Zato tudi ni potrebe, da se v teh misijah oblikuje poseben mehanizem za civilno-vojaško usklajevanje, saj so odnosi med vojaško in drugimi komponentami misije že določeni v veljavnih politikah $\mathrm{OZN}^{7}$ ter $\mathrm{v}$ mandatu in organizacijski strukturi operacije. ${ }^{8}$ Že v OZN torej obstaja več usklajevalnih mehanizmov za misije nasploh.

\footnotetext{
6 Rehsejevi ugotovitvi o nenaslavljanju vzrokov konflikta je mogoče ugovarjati. Ravno spremenjeni mandati in vidiki operacij (humanitarni in politični mandati) naj bi določali vzroke konfliktov (pogosto so to revščina in druge neenakosti ter slabo delovanje političnih institucij), medtem ko vojaške misije predvsem pomagajo vzpostavljati ali ohranjati varno okolje ali vsaj okolje brez odkritih oboroženih konfliktov.

Na primer: UN Administrative Committee on Coordination (ACC) Guidelines on the Functioning of the Resident Coordination System (24 September 1999); UN Secretary-General's Note of Guidance on Relations between Representatives of the Secretary General, Resident Coordinators and Humanitarian Coordination (11 December 2000); UN Secretary-General's Note of Guidance in Integrated Missions (17 January 2006), in DPKO's Policy Directive on Joint Operations centers and Joint Mission Analysis Centres (31 May 2006) (Coning, 2007, 5 - footnote 6).

8 Vključeni, na primer: Joint Operations Centre (JOC), Joint Mission Analysis Cell (JMAC), Integrated Mission Planning Team (IMPT) ipd. (Coning, 2007, 6).
} 
Uporaba terminov sodelovanje (kooperacija) nasproti usklajevanje (koordinacija) kaže na razlikovanje med Natovimi operacijami, v katerih je tudi na strateški ravni nujno civilno-vojaško sodelovanje, in kontekstom misij OZN, v katerih je vojaška komponenta vstavljena $\mathrm{v}$ misijo in udeležena $\mathrm{v}$ več usklajevalnih mehanizmih v celotni misiji. Z vidika OZN se usklajevanje nanaša na spekter odnosov, ki se vrstijo od koeksistence do kooperacije. Koncept usklajevanja je bil v OZN razvit v kontekstu humanitarnega civilno-vojaškega usklajevanja, v katerem se koeksistenca nanaša na položaj, pri katerem se med humanitarno skupnostjo in vojaško bojno silo deli minimum nujnih informacij. To najpogosteje vključuje delitev informacij o varnosti, premikih humanitarnih konvojev in menedžmentu skupnih virov (npr. pristanišča ali letališča). Sodelovanje se nanaša na maksimalno stanje civilnovojaškega usklajevanja, $\mathrm{v}$ katerem najdemo vrsto sodelovalnih odnosov med humanitarno skupnostjo in vojaško silo, ki pa je ne razumemo kot bojno silo. Ti odnosi vsebujejo skupno načrtovanje, delitev dela in informacij (Coning, 2007, str. 7). Coning ugotavlja, da se zdi, da Nato in OZN razumeta sodelovanje in usklajevanje nasprotno. V Natovem kontekstu je namreč sodelovanje razumljeno kot manj povezovalno v primerjavi z usklajevanjem, Nato tudi trdi, da je humanitarna skupnost pripravljena sodelovati, ne pa se usklajevati.

Vendar so terminologija in koncepti civilno-vojaškega usklajevanja različni že znotraj OZN. Kot ugotavlja Coning (2007, str. 8), najdemo pri OZN sicer dva skladna, čeprav različna pristopa $\mathrm{k}$ civilno-vojaškemu usklajevanju, in sicer humanitarnega in pristop mirovnih operacij. Humanitarni pristop je pristop Urada OZN za usklajevanje humanitarnih zadev, ki je pod vodstvom Medagencijskega stalnega odbora (Inter-Agency Standing Committee - IASC) razvil vrsto politik in smernic za humanitarno civilno-vojaško usklajevanje v OZN. Leta 2004 je bil koncept humanitarnega civilno-vojaškega usklajevanja v OZN s kratico UN CMCoord opredeljen kot bistven dialog in interakcija med civilnimi in vojaškimi akterji v humanitarnih krizah, ki je nujen, da se zaščitijo ter spodbujajo humanitarna načela, da se izognejo tekmovanju, da se minimalizirajo protislovja in se, kadar je treba, teži k skupnim ciljem. Temeljne strategije se vrstijo od koeksistence do sodelovanja. Usklajevanje je skupna odgovornost, ki se krepi s stiki in skupnim usposabljanjem (Coning, 2007, str. 8-10).

Humanitarni pristop poudarja prednost humanitarnih ciljev in delo humanitarnih organizacij, medtem ko naj bi se vojaške zmogljivosti vključevale, kolikor je najmanj mogoče, in znotraj humanitarnih načel ravnanja. ${ }^{9}$

Koncept civilno-vojaškega usklajevanja v kontekstu mirovnih operacij OZN mora pokriti vse mogoče scenarije misij in ustrezati celotnemu življenjskemu ciklu mirovne operacije, torej od stabilizacijske faze, ki se osredotoča na doseganje varnega okolja in zagotavljanje podpore humanitarnim akcijam, prek faze tranzicije do faze

\footnotetext{
Na kratko povzetih šest operativnih načel za uporabo vojaških zmogljivosti v humanitarnih operacijah (po Coning, 2007, 9).
} 
konsolidacije, ki je osredotočena predvsem na graditev miru. Oddelek Združenih narodov za operacije ohranjanja miru (Department for Peacekeeping Operations DPKO) je oblikoval posebno definicijo civilno-vojaškega usklajevanja. Sprejeta je bila septembra leta 2002. Glasi se:

Civilno-vojaška koordinacija Združenih narodov je sistem interakcije, ki vključuje izmenjavo informacij, pogajanja, odpravo nasprotij, medsebojno podporo in načrtovanje na vseh ravneh med vojaškimi elementi in humanitarnimi organizacijami, razvojnimi organizacijami in lokalnim civilnim prebivalstvom z namenom, da se dosežejo cilji Združenih narodov (Coning, 2007, str. 8-11).

Novejši dokumenti OZN civilno-vojaško usklajevanje v okviru misij ohranjanja miru, pri čemer uporabljajo kratico UN-CIMIC, opredeljujejo kot vojaško štabno funkcijo v integriranih misijah OZN, ki pospešuje vzajemno delovanje med vojaškimi in civilnimi sestavinami misije ter humanitarnimi razvojnimi akterji na območju misije, da podprejo cilje misije (UN-CM Coord Field Handbook, 2015, str. 77). De Coning in Holshek (2012, 15-17) pa opozarjata tudi, da sta interakciji med vojsko in civilnimi sestavinami misije ter vojsko in humanitarnimi organizacijami le del vloge civilno-vojaškega sodelovanja OZN. V tej vlogi CIMIC OZN deluje kot element za zvezo in deljenje informacij. V svoji drugi vlogi pa skrbi za zagotavljanje podpore pri ustvarjanju okolja, ki bo omogočalo izpolnitev mandata misije. Pri tem deluje posredno, predvsem pa se usmerja $v$ gradnjo lokalnih zmogljivosti in zaupanja.

\section{EVROPSKA UNIJA TER CIVILNO-VOJAŠKO SODELOVANJE IN USKLAJEVANJE}

EU je leta 2002 sprejela koncept o civilno-vojaškem sodelovanju v operacijah kriznega menedžmenta ${ }^{10}$, ki jih vodi (CIMIC Concept for EU-led Crisis Management Operations). Definicija civilno-vojaškega sodelovanja pri EU je: usklajevanje in sodelovanje $\mathrm{v}$ podporo misiji, usklajevanje med vojaškimi sestavinami operacij kriznega menedžmenta EU in civilnimi akterji (zunaj EU), vključno z nacionalnim prebivalstvom in lokalnimi oblastmi, ter mednarodnimi, nacionalnimi in nevladnimi organizacijami in agencijami (po Mustonen, 2008, 21). CIMIC izhaja iz vojaške perspektive, ki jo zanimata zlasti zaščita sil in s tem povezana potreba po sodelovanju z lokalnimi oblastmi in civilisti (Khol, 2006, str. 124). Kot ugotavlja Mustonen (2008, str. 21), definicija civilno-vojaškega sodelovanja v EU sicer odraža Natov koncept, je pa pogled EU širši in poudarja možnost uporabe različnih instrumentov, vojaških in civilnih, v operacijah kriznega menedžmenta.

Operacije kriznega menedžmenta EU razvijajo dve vrsti interakcij, ki spadajo v civilno-vojaško sodelovanje. Te operacije so vsaj deloma odvisne od civilnih institucij

\footnotetext{
${ }^{10}$ Evropska unija ne uporablja splošnega termina mirovne operacije, ampak govori o operacijah civilnega in vojaškega kriznega menedžmenta, pri čemer razumemo kot mirovne operacije tiste, ki se izvajajo v okviru skupne varnostne in obrambne politike (glej Garb in Ober, 2005, str. 97).
} 
in prebivalstva zaradi virov, informacij in tudi varnosti, poleg tega pa vojaške sile sodelujejo z drugimi mednarodnimi ali nevladnimi organizacijami. Civilno-vojaško sodelovanje je torej tako notranja vojaška podporna funkcija kot značilnost operacij kriznega menedžmenta EU, ki naj bi povečevala učinkovitost operacij (Khol, 2006, str. 124).

Ker se je EU odločila, da bo razvijala tako vojaške kot civilne zmogljivosti za krizni menedžment, je za notranje usklajevanje razvila koncept civilno-vojaškega usklajevanja (Civil-Military Co-ordination - CMCO). Svet EU je dokument o tem usklajevanju ${ }^{11}$ sprejel novembra 2003, pomen razvoja civilno-vojaškega usklajevanja pa se je znotraj evropske varnostne in obrambne politike poudarjal že od leta 1999. V splošnem je med civilno-vojaškim sodelovanjem in usklajevanjem mogoče potegniti ločnico, in sicer tako, da sodelovanje razumemo kot podporno funkcijo vojaški misiji (ki pokriva sodelovanje z zunanjimi akterji na taktični ali operativni ravni), usklajevanje pa je bilo izvirno oblikovano za notranje usklajevanje (ki pokriva načrtovanje, politično sprejemanje odločitev in implementacijo akcij EU v kriznem menedžmentu), lahko pa ga razumemo tudi kot pogoj za sodelovanje z zunanjimi akterji (po Mustonen, 2008, str. 21-22; Mazurkiewicz, 2014, str. 129-130).

Zamisel CMCO EU naj bi sicer bolj kot poudarjanje in razvijanje natančne strukture in postopkov vodila potreba po razvoju kulture usklajevanja, ki naj bi se vgrajevala v aktivnosti EU. Khol (2006, str. 127) ob tem ugotavlja, da snovanje skupnega modela civilno-vojaškega usklajevanja na ravni EU zapletajo različne nacionalne kulture civilno-vojaških razmerij držav članic EU. Poleg tega so še drugi dejavniki zapletanja. Mednje lahko štejemo različne institucionalne kulture vojakov in civilnega osebja, čeprav so zaradi skupne lokacije delovni stiki med vojaškim in civilnim osebjem v direktoratu generalnega sekretariata Sveta olajšani. Problematično je tudi nesorazmerje med vojaško in civilno sestavino, saj je civilnega osebja na sekretariatu že vseskozi precej manj. Kot ugotavlja Khol, je okvir kriznega menedžmenta EU oblikovala vojska, civilni prispevek pa je prišel pozneje in ni bistveno spremenil pristopa k strateškemu planiranju. Civilna stran tudi nima vstopa v verigo poveljevanja. Razlika med civilnim in vojaškim pristopom je vidna tudi v odnosu (bližini) do lokalnega prebivalstva. Vojska je usposobljena za najmanjši mogoči stik $\mathrm{z}$ njim in izolirana $\mathrm{v}$ vojaških bazah, medtem ko je civilno osebje EU $\mathrm{v}$ stalni interakciji z lokalnimi oblastmi in pomešano med lokalno prebivalstvo. Naslednja razlika med vojaki in civilisti v operacijah kriznega menedžmenta je $\mathrm{v}$ novačenju za operacijo. V vojskah večine držav EU je razmestitev v tujini razumljena kot običajna naloga za vojaka. Za delo v operacijah je torej vojake precej preprosto dobiti. Drugače je s civilnimi eksperti. Njihovo novačenje temelji praviloma na prostovoljni odločitvi posameznika, poleg tega je različne strokovnjake (zlasti na ozkih strokovnih področjih) iz domačih struktur zelo težko dobiti (običajno so v službah pri državnih ali lokalnih oblasteh) (po Khol, 2006, str. 127-128).

\footnotetext{
"I Civil-Military Coordination (CMCO), Council Document 14457/03, 7 November 2003 (Khol, 2006 opomba 11).
} 
Ko govorimo o sodelovanju vojske in civilnih akterjev na področju operacij kriznega menedžmenta v EU, moramo omeniti še civilno-vojaško celico (Civilian-Military Cell - CMC), ki je bila znotraj Vojaškega štaba EU ustanovljena decembra 2003. Med različnimi nalogami na področju strateškega planiranja je tudi planiranje skupnih civilno-vojaških operacij (Khol, 2006, str. 130-132; European Union Military Staff, 2009).

\section{SODELOVANJE VOJSKE IN HUMANITARNIH ORGANIZACIJ}

Besedno zvezo civilno-vojaško sodelovanje različni akterji uporabljajo v različnih kontekstih. Skupnost nevladnih organizacij uporablja izraz kot termin, ki se nanaša na vojaško vključevanje v humanitarno pomoč (Rehse, 2004, str. 13). Nevladne organizacije zavračajo vpletanje vojske v »humanitarni prostor«. Vidijo ga kot legitimizacijo intervencije s prizadevanjem za druge cilje ali za prikrivanje politične neuspešnosti. Verjamejo, da stapljanje vojaških in humanitarnih ciljev kompromitira humanitarne cilje in načela. Skupnost nevladnih organizacij neprestano opozarja, da vojske ne moremo jemati kot nevtralno in nepristransko, saj jo nadzoruje politika. Povezovanje nepristranskih humanitarnih akcij z vojaškimi cilji, ne glede na to, ali so stvarni ali le zaznani, vodi tudi k tveganju, da bodo humanitarni delavci zaznani kot sovražniki, s čimer bo ogrožena njihova osebna varnost. Mešanje mandatov naj bi tudi zmanjševalo uspešnost humanitarne pomoči ali celo onemogočalo nepristransko humanitarno delo. Zamisel, da bi bile humanitarne akcije podrejene vojski, je pri humanitarnih organizacijah povzročila hud odpor. Humanitarna skupnost vztraja pri tem, da mora razdeljevanje pomoči potekati po načelih nepristranskosti, nevtralnosti in neodvisnosti. Po drugi strani pa je vojska odkrila, da njena nova vloga v mirovnih operacijah zahteva učinkovito upravljanje za področje vojaško-humanitarnega prekrivanja (Rehse, 2004, str. 13-14).

Sodobne večdimenzionalne operacije v podporo miru se osredotočajo na civilno in humanitarno področje. Takšna širitev operacij lahko vodi do problematičnih odnosov ali celo do tekmovanja med vojsko in humanitarnimi organizacijami. Mednarodni odbor Rdečega križa (MORK) celo ugotavlja, da se zaradi zamegljene ločnice med vojaškim in humanitarnim delovanjem ruši koncept humanitarnega delovanja, ki je jedro mandata in aktivnosti odbora (Studer, 2001, str. 367).

Mednarodni odbor Rdečega križa je zaskrbljen, da bi humanitarna prizadevanja postala del političnega procesa in se tako politizirala. Politični proces naj bi sicer vodil v rešitev konflikta (pri tem je nujna tudi podpora vojaških sil), a humanitarne akcije so usmerjene v lajšanje trpljenja ljudi, ki nastaja zaradi krize. Humanitarno delovanje mora biti strogo ločeno od političnih ciljev mirovne operacije. Odbor zato zagovarja nevtralno in nepristransko humanitarno delovanje sredi konflikta (po Studer, 2001, str. 368, 372). Nasprotuje tudi neposrednemu vključevanju vojske v humanitarne aktivnosti, saj se želi izogniti lokalnemu razumevanju, da so humanitarne akcije povezane s političnimi in vojaškimi cilji, zato zahteva zelo jasno razločevanje med operacijami v podporo miru in humanitarnimi aktivnostmi (Rehse, 
2004, str. 41). Usmerjevalni odbor za humanitarni odziv (Steering Committee for Humanitarian Response - SCHR), ki je koalicija devetih največjih mednarodnih humanitarnih organizacij (član je tudi Mednarodni odbor Rdečega križa), je vojaško izvajanje humanitarne pomoči sicer ločil na izvajanje v »normalnih okoliščinah« in V »izjemnih okoliščinah«. V »normalnih okoliščinah«, ko humanitarne organizacije ustrezno opravljajo svoje delo, za vojsko ni primerno, da izvaja akcije na humanitarnem področju ${ }^{12}$ (Rehse, 2004, str. 41-42).

Zakaj vojska želi biti povezana s humanitarnim delovanjem? Vojska verjame, da so za uspeh vojaške operacije bistveni tudi dobri odnosi z lokalnim prebivalstvom. Humanitarno delo sicer ni glavna naloga vojske, se pa gleda nanj kot na pomožno nalogo v okviru doseganja cilja sprejemljivosti misije. Drugo, bolj razširjeno mnenje v vojski je, da lokalno prebivalstvo pričakuje, ne glede na mandat, da bodo »mirovniki« pomagali pri skrbi za njihove potrebe, še zlasti, kadar humanitarne organizacije same ne obvladujejo razmer. Nekatere vlade pa s humanitarno dejavnostjo svojih vojsk v mirovnih operacijah (in zlasti z opozarjanjem na humanitarni značaj dejavnosti) tudi želijo izboljšati domačo podobo vključenosti v operacije (Studer, 2001, str. 378-379).

Humanitarno delo vojske, ki se je posebno razmahnilo po neuspehih mirovnih operacij v Mogadišu, Kigaliju in Srebrenici (zato se je namreč zmanjšala politična volja po mandatih, ki bi bili usmerjeni v preprečevanje konfliktov, raje se je tvegalo z mešanjem humanitarnih in političnih mandatov ter vlog; politično in vojaško delovanje se zamenja s humanitarnim), prinaša s seboj dve vrsti nevarnosti. Prva je, da se lahko zgodi, da so mednarodne vojaške sile videne kot stran v konfliktu, zato je v trenutku, ko misija od njih zahteva uporabo sile, njihovo humanitarno delovanje kompromitirano. Obstaja pa tudi skušnjava, da humanitarna pomoč postane odvisna od privolitve strani v sporu, pri čemer bi politična telesa postavljala politične pogoje. Druga nevarnost je, da humanitarno delovanje vojsko lahko odvrača od njenega glavnega cilja. Vojaki so tako uporabljeni za »zdravljenje simptomov in ne bolezni«. Mednarodni odbor Rdečega križa je še zlasti zaskrbljen zaradi nevarnosti, da V očeh vojskujočih se strani oslabi koncept nepristranskega humanitarnega delovanja. Ne zavrača humanitarnega delovanja vojske kot takšnega, ampak ga bolj skrbi škodljiv učinek na civilno humanitarno delovanje, na slabšanje podobe civilnih humanitarnih delavcev (skrb, da se ta podoba ne bi spremenila iz podobe $»$ nedolžnih opazovalcev« v podobo potencialnih strani v konfliktu). V pokonfliktnih razmerah sicer humanitarna vloga vojske ni tako vprašljiva kot v konfliktnih, čeprav nekaj nevarnosti zaradi prepletanja humanitarnega in vojaškega delovanja ostaja, zlasti ob obnovitvi sovražnosti (Studer, 2001, str. 373-375).

\footnotetext{
12 Zlasti se ugovor nanaša na projekte stila hitrega vpliva (Qiuck Impact Projects - QIPs), ki so namenjeni mednarodni publiciteti in psihološkim razlogom, da se ohranja javna podpora misiji in izboljšuje morala osebja. SCHR trdi, da ti projekti služijo izboljševanju uspeha vojaške misije in nanje ne moremo gledati kot na humanitarne (Rehse, 2004, 42). QIPs sicer pozna tudi OZN, in sicer jih definira kot majhne, hitro izvršljive projekte, ki so v korist prebivalstvu. Voperacijah OZN se uporabljajo za ustanavljanje in graditev zaupanja $v$ misijo, njen mandat in mirovni proces, torej izboljšujejo okolje za učinkovito uveljavljanje mandata (DPKO Policy Directive, 12. februar 2007).
} 
Studer (2001, str. 375-376) opozarja tudi na razpravo, v kateri se pojavljata dva argumenta proti humanitarnemu delovanju vojske. Vojska naj bi namreč največ prispevala $\mathrm{k}$ humanitarnemu delovanju ravno s tem, da skrbi za red in varnost. Zgolj humanitarna misija ne bi nikoli smela biti razlog za namestitev vojaških enot, niti ne bi smela služiti kot »figov list« za prikrivanje politične nedejavnosti. In drugič, upoštevati je treba, da ima humanitarna pomoč tako pozitivne kot negativne posledice. Po eni strani pripomore k ustvarjanju razmer za reševanje konflikta, po drugi pa lahko konflikt tudi podaljšuje.

O delovanju vojske v mirovnih operacijah je na politično-odločevalski ravni (vsaj bilo) jasno, da je primarna vloga vojske vojaška, se pa v zadnjem času pojavlja težnja po politiki neposrednega vključevanja vojske $\mathrm{v}$ civilne in humanitarne naloge. $\mathrm{Na}$ operativni ravni se skušajo vojaške in humanitarne organizacije bolj povezati, zlasti v obliki aktivne vojaške podpore humanitarnemu delu. Za humanitarne organizacije je pravi izziv, da jasno ločijo humanitarno delovanje od vojaškega, pri tem pa ohranijo prednosti sodelovanja z vojsko (Studer, 2001, str. 376-377).

Mednarodni odbor Rdečega križa zavrača termin CIMIC (civil-military cooperation) za opisovanje svojega odnosa z vojsko, saj CIMIC zlasti vidi kot vojaško funkcijo. Nevarnost civilno-vojaškega sodelovanja je $\mathrm{v}$ tem, da lahko privede vojsko do tega, da gre prek svojega (vojaškega) mandata in se osredotoči bolj na humanitarne aktivnosti kot na naloge miru in varnosti (Studer, 2001, str. 378).

Mednarodni odbor Rdečega križa se torej nekako upira tesnemu usklajevanju svojih aktivnosti $\mathrm{z}$ aktivnostmi vojske. Razlogi so $\mathrm{v}$ njegovem posebnem mandatu, $\mathrm{v}$ načelih in »kulturi«. Eden izmed argumentov proti sodelovanju in usklajevanju je mogoče strniti v stavek: »vojska lahko postane del problema in ne rešitve«. Težava lahko nastane, če vojska ne spoštuje dovolj mednarodnega humanitarnega prava (primer v Somaliji leta 1992). Drugi pogosto uporabljani argument odbora proti sodelovanju z vojsko v mirovnih operacijah pa je, da bi vojska lahko potrebovala odbor kot nevtralnega posrednika (primer v Somaliji, ko je obiskal osebe, ki jih je priprl UNOSOM II ${ }^{13}$, in Aididove zapornike; primer Kosova, ko je Mednarodni odbor Rdečega križa obiskal osebe, ki jih je priprl Kfor). Nekaj težav povzročata tudi zbiranje in delitev informacij. Vprašanje namreč je, ali bi imel odbor koristi od informacij, ki bi jih dobil od vojske, pa tudi, kakšne informacije naj bi dajal vojski. Zavezan je namreč zaupnosti, kar je omejevalni dejavnik pri zagotavljanju informacij. Studer (2001, str. 381) sicer ugotavlja, da vojska načeloma razume in sprejema to zaupnost.

Nadalje je nekoliko vprašljivo tudi zagotavljanje vojaškega spremstva humanitarnim agencijam. Humanitarna skupnost sicer o tem nima enotnega stališča. Stališče Mednarodnega odbora Rdečega križa je, da ne uporabljajo oboroženega spremstva niti zaščite vojakov OZN. Meni namreč, da bi povezava s komerkoli oboroženim

${ }^{13}$ UNOSOM II je bila operacija OZN v Somaliji v letih 1993-1995. 
lahko bolj ogrozila kot varovala njegovo osebje. Drugače je z opremo, ki jo redno hranijo in varujejo mirovne sile. Po mnenju odbora takšna zaščita lastnine proti banditstvu in drobnemu kriminalu ne more ogroziti njegove podobe kot nevtralne in nepristranske institucije.

Kaj pa uporaba vojaških zmogljivosti za humanitarno delovanje? V 80. in 90. letih prejšnjega stoletja so se vojaške zmogljivosti v humanitarnih operacijah veliko uporabljale (npr. zračni most v Etiopiji leta 1985 in 1988 ipd.). V zadnjem času je Mednarodni odbor Rdečega križa pri uporabi vojaških zmogljivosti pazljivejši (povsem zavrača je sicer ne), saj vojska uporablja svoje zmogljivosti za različne naloge, med katerimi so tudi takšne, ki bi odbor lahko kompromitirale.

Pogosto se izkaže, da je glavna ovira učinkovitemu sodelovanju humanitarnih organizacij in vojske kulturna neskladnost (na primer humanitarnost vojske, sodelovanje humanitarnih delavcev $\mathrm{v}$ vojaških aktivnostih težje predstavljivo; vojaška linija poveljevanja, pravila in operativni ukazi pri vojski, neodvisnost mišljenja in precej odločanja neposredno na terenu pri humanitarnih delavcih). Pred skupnim delovanjem je nujno, da vojska dobi vpogled v načine dela humanitarnih delavcev in da se ti seznanijo z vojaškimi pristopi. Spoznati in spoštovati morajo tudi mandate drug drugega, da se izognejo nesporazumom. Usposabljanje pomaga dosegati skupno znanje in povečuje predvidljivost (povzeto po Studer, 2001, str. 380-384).

Za konec še zanimive ugotovitve iz empirične raziskave Mojce Pešec o sodelovanju akterjev znotraj Natovega celovitega pristopa v operacijah. Na vprašanja v raziskavi so odgovarjali izbrani predstavniki civilnih in vojaških organizacij, predvsem z izkušnjami iz Afganistana (več v Pešec, 2015, str. 190). V raziskavi je avtorica anketiranim med drugim postavila tudi vprašanje, če so njihove matične organizacije (Nato, OZN, UNICEF, CCOE, Mednarodna organizacija za migracije, Norveški svet za begunce itn.) izvedle strukturne ali procesne spremembe, ki bi izboljšale sodelovanje s civilnimi oziroma vojaškimi akterji v kompleksnih krizah. Odgovori na to vprašanje so potrdili, da si vladne organizacije in Nato prizadevajo, da bi $\mathrm{v}$ kompleksnih krizah vzpostavili boljše sodelovanje med vojaškimi in civilnimi akterji, pri tem pa upoštevajo operativne usmeritve OZN. Vlade in Nato so za boljše sodelovanje razvili nekatere zmogljivosti, medtem ko nevladne organizacije in posamezne agencije OZN v posameznih situacijah pristajajo na usklajevanje aktivnosti, skupno delovanje pa večinoma zavračajo. V zaostrenih varnostnih razmerah so nekatere izmed njih na sodelovanje $\mathrm{z}$ vojaškimi akterji pripravljene, druge pa se od njih povsem umaknejo. Odgovori anketiranih iz različnih organizacij na vprašanje o optimalnih oblikah sodelovanja so precej različni, vsi pa vidijo možnosti v medsebojni izmenjavi informacij (Pešec, 2015, str. 208-212). 
Sklepne Pregled vsebine in uporabe termina civilno-vojaško sodelovanje, najpogosteje ugotovitve poznanega pod kratico CIMIC, pokaže, da v okviru sodobnih mirovnih operacij tako v vsebini kot uporabi tega termina ni enotnosti. Pa ne samo to, srečamo celo nasprotovanje sodelovanju na terenu, kar vidimo zlasti v razmerju med humanitarnimi organizacijami in vojaškimi silami.

Vsekakor pa lahko ugotovimo, da sodobne mirovne operacije, ki jih označujeta večdimenzionalnost (koncept Organizacije združenih narodov) in celovitost (koncept Nata) v pristopih in kompleksnost v akterjih, potrebujejo sodelovanje in tudi usklajevanje teh akterjev pri opravljanju njihovih dejavnosti. Za opisovanje procesov vzpostavljanja tega odnosa se je v mednarodni skupnosti najprej začel razvijati termin civilno-vojaško sodelovanje, ki ga je kmalu za eno svojih doktrin delovanja v mirovnih operacijah privzel Nato, pozneje pa še EU, predvsem za tisti del aktivnosti, ki se nanašajo na podporo vojski. Danes zato CIMIC povezujemo predvsem z eno izmed funkcij vojske v Natovih operacijah (tako na ozemlju operacij kot doma) in vojaških operacijah Evropske unije, preostali akterji pa so začeli uporabljati nove termine in kratice, pri čemer je večjo vlogo dobilo usklajevanje namesto sodelovanja.

Potreba po sodelovanju in usklajevanju vojaškega in civilnih akterjev se je pokazala zlasti po razvoju razmer (in operacij) v Bosni in Hercegovini od leta 1995 ter se nasploh stopnjevala $\mathrm{z}$ večanjem števila civilnih akterjev v mednarodnih operacijah in na misijah.

Še bolj kot sodelovanje med vojsko in civilnimi agencijami različni akterji poudarjajo pomen koordinacije (usklajevanja) med vojsko in drugimi akterji. Nekatere opredelitve civilno-vojaškega sodelovanja (na primer Natova) vsebujejo tako sodelovanje kot usklajevanje. Druge (na primer OZN) se bolj osredotočajo na usklajevanje. Ena izmed razlag pravi, da gre pri uporabi različnih pojmov za to, da OZN razume sodelovanje le kot najmočnejši odnos med sestavinami misije, kot so vojaška, civilna in policijska

S pojmom usklajevanje pa želi pokazati, da se lahko razvijejo tudi manj trdne oblike sodelovanja, včasih zgolj koeksistenca. Pojem usklajevanje naj bi tako pomenil le lestvico, na kateri se razvijejo različni odnosi med omenjenimi akterji (glej Coning in Holshek, 2012, 28-29).

Deloma se kaže nezdružljivost delovanja humanitarnih organizacij z delovanjem aparata mirovnih operacij, zlasti z vojsko. Ob tem humanitarne organizacije izražajo strah pred politizacijo njihovega delovanja in večjo ogroženostjo, če bi se njihovo delovanje prepletalo z delovanjem (čeprav humanitarnim) vojaških mirovnih sil. Humanitarno delovanje vojske naj bi bila le podporna funkcija vojaškemu delovanju v mirovnih operacijah, ki je še vedno temeljno. Kot ugotavlja Ritjens (2006, str. 6), sta (torej) pri civilno-vojaškem sodelovanju razvidni tako njegova politična kot humanitarna identiteta. 


\section{Literatura}

1. AJP-3.4.9. Allied Joint Doctrine for Civil-Military Cooperation. February 2013.

2. AJP-9. NATO Civil-military Co-operation (CIMIC) Doctrine. June 2003.

3. Ankersen, C. (ed)., 2007. Civil-military Cooperation in Post-conflict Operations: Emerging theory and practice. Cass Military Studies.

4. CIMIC Centre of Excellence. Dostopno na http://www.cimic-coe.org/, 25. 3. 2016

5. Coning, C., 2007. Civil-Military Coordination Practices and Approaches within United Nations Peace Operations. Journal of Military and Strategic Studies. Fall, Vol.10, Issue 1.

6. Coning, C., Holshek, C., 2012. United Nations Civil-Military Coordination (UN-CIMIC). Williamsburg, USA: Peace Operations Training Institute.

7. DPKO Policy Directive, 12 February 2007. Quick Impact Projects (QIPS). United Nations Department of Peacekeeping Operations.

8. European Union Military Staff. Brochure. February 2009. Dostopno na: www.consilium. europa.eu/eums, 14. 5. 2009.

9. Garb, M., in Ober, K., 2005. Mirovne operacije Zahodnoevropske in Evropske unije. V: Jelušič, L., (ur.): Mirovne operacije in vloga Slovenije. Ljubljana: Fakulteta za družbene vede, str. 97-109.

10. Gebhard, C., 2008. Civil-Military Coordination and Cooperation in the Context of the EU's Crisis Management: CMCO versus CIMIC. Conceptual and Terminological Clarifications Second version. Info Aktuell 01/2008. National Defence Academy, Institute for Peace Support and Conflict management.

11. Henriksson, K. (ed.), 2008. CMC Finland Yearbook 2008. CMC Finland Civilian Crisis Management Studies, Volume 1, Number 6/2008.

12. Khol, R., 2006. Civil-Military Co-ordination in EU crisis management. V: Agnieszka Nowak (ed): Civilian Crisis management: the EU way. Chaillot Paper, No. 90, June 2006.

13. Logar Kelc, M., 2007. Civilno-vojaško sodelovanje. Diplomsko delo. Fakulteta za družbene vede, Ljubljana.

14. M2 Presswire. Nov. 16, 2007. Norwegian Government: Multidimensional and Integrated Peace Operations: Trendsand Challenges. Coventry.

15. Mazurkiewicz, A., 2014. NATO and EU approach towards civil-military relations in military operations. Polityka i Spoleczeństwo, 2(12), str. 125-140.

16. MC 411/1. NATO Military Policy on Civil-Military Co-operation. NATO International Military Staff, 2002.

17. Multinational Cimic Group. Dostopno na http://www.cimicgroup.org/, 25. 3. 2016.

18. Mustonen, J., 2008. Coordination and Cooperation on Tactical and Operational levels. Stdying EU-ESDP Crisis management Instruments in Bosnia and Herzegovina. $V$ : Henriksson, Kirsi (ed.): CMC Finland Yearbook 2008. CMC Finland Civilian Crisis Management Studies, Volume 1, Number 6/2008, str. 1-41.

19. NATO - SHAPE - Civil Military Cooperation (CIMIC). Dostopno na: http://nato.int/ shape/community/pio/contact_cimic.htm, 16. 3. 2009.

20. Pě̌ec, M., 2015. NATO in celovit pristop pri reševanju kompleksnih kriz. Doktorska disertacija. Ljubljana: FDV.

21. Ramsbotham, O., Woodhouse, T., 1999. Encyclopedia of international Peacekeeping Operations. Santa Barbara: ABC-CLIO.

22. Rehse, P., 2004. CIMIC: Concepts, Definitions and Practice. IFSH Heft 136. IFSH Hamburg, junij, 2004.

23. Ritjens, S. J. H., 2006. Civil-military cooperation in response to a complex emergency: just another drill? Dissertation. University of Twente, the Netherlands.

24. SHAPE News Release, 05 May 2009: The Multinational Civil-military Cooperation (CIMIC) Group HQ is officially established. Dostopno na http://www.nato.int/shape/ news/2009/05/090505a.html, 15. 05. 2009. 
25. Studer, M., 2001. The ICRC and civil-military relations in armed conflict. International Review of the Red Cross, Vol. 83, No. 842, str. 367-391.

26. UN-CMCoord Field Handbook (v1.0). 2015. Geneva: United Nations.

27. Zandee, D., 1999. Civil-military interaction in peace operations. NATO Review, Vol. 47, No. 1, Spring, str. 11-15. Webedition. 


\section{GORSKE ENOTE NEMŠKIH OBOROŽENIH SIL}

\section{THE GERMAN ARMED FORCES MOUNTAIN TROOPS}

Povzetek V članku je predstavljen kratek zgodovinski pregled gorskih enot nemških oboroženih sil. Opisan je njihov razvoj od začetkov, ko so delovale kot specializirane enote pehote, prek obdobja obeh vojn in hladne vojne do današnjega položaja $\mathrm{v}$ kompleksnem in večdimenzionalnem bojevanju. Na kratko so predstavljene tudi posebne kompetence pripadnikov teh enot, $\mathrm{v}$ nadaljevanju pa avtor predstavi še trenutno opremo in strukturo gorskih enot ter njihove sedanje zmogljivosti. Članek ponuja tudi kratek pregled sodelovanja enot in njihovih pripadnikov na mednarodnih misijah, na katerih nemške oborožene sile sodelujejo. Na koncu je predstavljena vaja brigadne ravni Edelweiss 2015 kot primer izzivov, s katerimi se srečujejo nemška kopenska vojska in njene gorske enote v okolju kompleksnega in večdimenzionalnega bojevanja.

Ključne Nemške oborožene sile, gorsko bojevanje, naloge, taktične operacije, misije v besede podporo miru.

Abstract The article provides a short historical overview about the German Armed Forces Mountain Troops. It describes the development from its beginnings as specialized infantry through two World Wars and the cold war era until today's situation in a complex and multidimensional warfighting environment. In addition, a short view into some specific qualifications of the Mountain Troops is given. Furthermore, it highlights the current equipment and structure to show the present capability profile of the German Armed Forces Mountain Troops. Moreover, the article gives a short overview of the participation of units and soldiers in international missions, the German military was and is involved in. Finally, the Brigade Battle Exercise EDELWEISS2015 is presented as an illustration of the challenges the German Army and its Mountain Forces have to face in the afore mentioned complex and multidimensional warfighting environment. 


\section{Key words German Armed Forces, mountain warfare, missions, tactical operations, peace} support missions.

\section{Introduction}

The German Mountain Infantry Brigade 23 "BAYERN" ("BAVARIA"), the core of German Armed Forces mountain troops, is specialized in infantry warfighting in difficult to extreme terrain, including high altitudes, and under extreme climate and weather conditions.

In addition to regular peacetime activities, this unique unit looks back on a vast operational experience, having been deployed to multiple theatre environments on the Balkans, Afghanistan and some African countries such as Somalia and Mali. To be able to master its specific tasks, training and practice concepts as well as a demanding training environment are required, which cannot be carried out solely at a national level. For this reason, close cooperation with other European nations like Austria or France is paramount. This article provides an overview of the history and the capabilities of German mountain troops and offers an insight into the current implementation of the current training concept with reference to the recent Brigade Combat Exercise EDELWEISS 2015.

\section{HISTORY OF GERMAN MOUNTAIN TROOPS}

Despite the fact that mountain warfare always had played a role in German war history, the history of German mountain troops, specifically dedicated to mountain warfare, is a rather young one. It all started during the First World War, when Germany had to face French alpine troops in the Vosges Mountains and, later in 1915, decided to support the Austro-Hungarian Empire in the alpine theatre, fighting the Dolomites campaign. For this reason, the German Empire trained and equipped specialized forces, mostly from its southern states like Baden, Württemberg and Bavaria. This circumstance marks the origin of regular German Mountain Troops. From this time on, German Mountain Troops wore the Edelweiss, a metal version of a flower, which only grows at high altitude, on their caps. This symbol was donated by AustrianHungarian Mountain Troops, showing their gratitude for the support they received by their German brothers-in-arms.

Since the Versailles Treaty denied Germany any mountain troops, Germany started to inaugurate the capability of mountain warfighting again in 1937. Throughout the Second World War, Germany had 18 Mountain Divisions available, which, of course, did not operate only in their designated high-altitude terrain, but were mostly used as regular infantry divisions. However, due to their character as specialized infantry, they were often utilized as a spearhead for smaller scale operations, like the Norwegian campaign, or, together with paratroopers, the landing on the Greek island of Crete. 
During the Second World War, the German Mountain Infantry did not only excel in bravery, but was also responsible for war crimes, which had been subject to various investigations in the post-war era (Jeschonnek, 2015, p. 79).

After the Second World War and with the foundation of the Bundeswehr (Federal Armed Forces) in 1956, Germany considered the capability of mountain warfare as crucial for success even in early cold war scenarios. Therefore, the Bundeswehr's $1^{\text {st }}$ Mountain Division was inaugurated as the eighth of twelve divisions, which formed the major fighting force of the new German Army. Initially, the $1^{\text {st }}$ Mountain Division encompassed the Battle Groups A8 and B8, the Army Aviation Company 8, the Mountain Signals Company 8, the Mountain Armoured Reconnaissance Company 8, the Mountain Artillery Regiment 8, the Mountain Engineer Battalion 8 and four subordinated mountain infantry battalions.

Since then, as most western armies, the Bundeswehr and its units have seen severe and multiple changes in their structure, accompanied by cuts in strength and capabilities. This indeed impacted also the German Mountain troops.

In 1959, the battle groups were renamed "brigades": Battle Group A8 became the Mountain Infantry Brigade 23 (home garrison: Bad Reichenhall) and B8 became the Mountain Infantry Brigade 22 (home garrison: Mittenwald). In 1960, a new and unique unit in the German military was introduced with the first pack animal platoon. It was the precursor of today's Operations and Training Centre for Pack Animals 230 (Einsatz- und Ausbildungszentrum für Tragtierwesen 230). In 1981, the Mountain Infantry Brigade 23 was restructured and all mountain infantry battalions of the German Army were attached to this brigade. The Mountain Infantry Brigade 22 was transformed into the Mechanized Infantry Brigade 22, which also moved their home garrison from Mittenwald to Murnau. Due to operational considerations after the fall of the Berlin Wall, the latter was disbanded in 1993.

After the conclusion of the German reunification in 1990, the Infantry Battalion 571 in Schneeberg, Saxony became part of the Mountain Infantry Brigade 23 as Mountain Infantry Battalion 571 in 1996. Finally, it was disbanded in 2007.

On the 26 June 2001, the parent $1^{\text {st }}$ Mountain Infantry Division was disbanded in the course of a reorganisation of the German Army and the Mountain Infantry Brigade 23 was attached to the $10^{\text {th }}$ Armoured Division, the only remaining division-sized unit in Southern Germany.

In 2003, the Mountain Maintenance Battalion 8 joined the brigade as Mountain Logistic Battalion 8 and the Mountain Engineer Battalion 8, which had been temporarily outside of the Mountain Troops, was re-attached to the brigade from Engineer Brigade 60 as well. In 2004, the Federal Ministry of Defence took the decision to keep the capability of Mountain Warfighting in the German Armed Forces. 
Consequently, the current garrisons of the Brigade were massively enlarged and the brigade received a new structure with three Mountain Infantry Battalions, one Mountain Engineer Battalion, one Mountain Reconnaissance Battalion, one Mountain Logistic Battalion, one Mountain Signals Battalion and the Operations and Training Centre for Pack Animals. In 2008, the Mountain Infantry Brigade 23 celebrated its $50^{\text {th }}$ anniversary. On the occasion of this event, the brigade received its epithet Bayern (Bavaria) by the Prime Minister of the Federal State of Bavaria (editorial office German Army, 2014).

\section{CURRENT STRUCTURE AND EQUIPMENT}

Since its $50^{\text {th }}$ anniversary, the brigade was again subject to some slight structural adjustments.

Currently, the brigade is organized as follows

- Headquarters and Signals Company in Bad Reichenhall,

- Mountain Infantry Battalion 231 in Bad Reichenhall,

- Mountain Infantry Battalion 232 in Bischofswiesen,

- Mountain Infantry Battalion 233 in Mittenwald,

- Mountain Reconnaissance Battalion 230 in Füssen,

- Mountain Support Battalion 8 in Füssen

- Mountain Engineer Battalion 8 in Ingolstadt,

- Operation and Training Centre for Pack Animals 230 in Bad Reichenhall.

Nowadays, more than 6,500 soldiers serve in the Mountain Infantry Brigade 23, which makes it the Bundeswehr's strongest brigade in personnel figures.

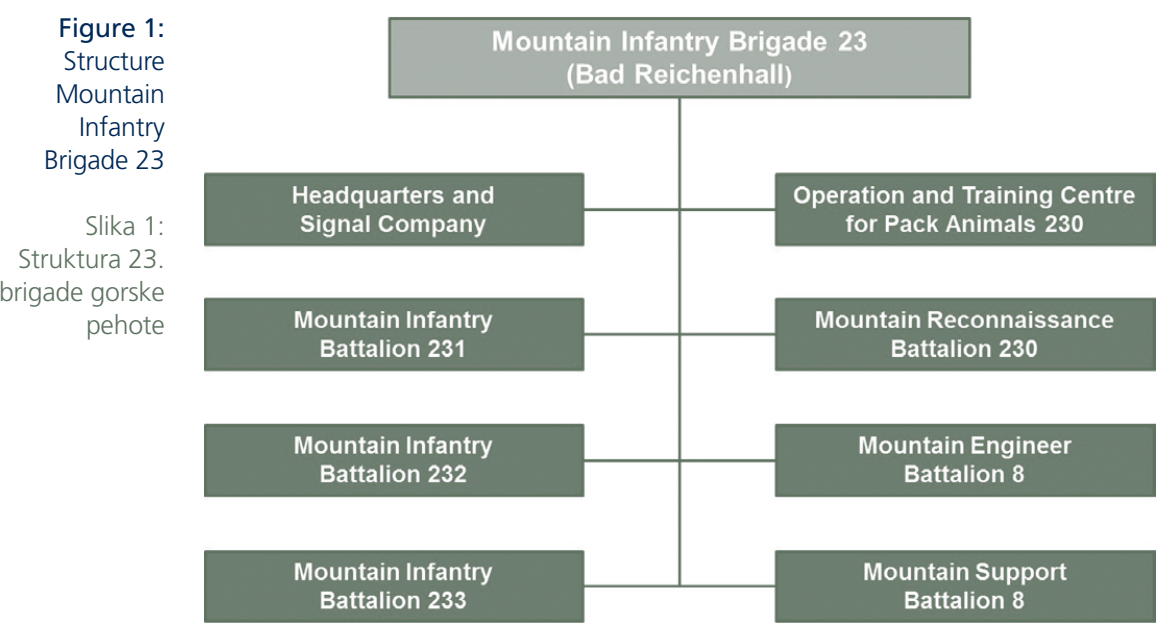


The three Mountain Infantry Battalions (231, 232 and 233) represent the core of the brigade's fighting force. In addition to three (light) mountain infantry companies, each battalion consists of an additional heavy mountain infantry company, a training and support company, and a headquarters and support company. The heavy company is comprised of a mortar platoon, a reconnaissance platoon, an antitank platoon and a machine cannon platoon. The headquarters and support company has a high-altitude mountain infantry platoon, where specialized assets and Heeresbergführer (army mountain guides) are pooled.

Mountain Infantry Battalion 231 differs from 232 and 233 in its tactical mobility on the ground, being equipped with BOXER-type MRAVs (multi-role armoured vehicle) whereas Mountain Infantry Battalions 232 and 233 utilize the tracked BV 206/206S for tactical movement.

The Mountain Reconnaissance Battalion 230 is structured into a headquarters and support company, two highly mobile reconnaissance companies, one unmanned aerial vehicles (UAV) company and a supply company. The reconnaissance companies are equipped with either the FENNEK reconnaissance vehicle or the BV $206 \mathrm{~S}$ in a reconnaissance version. The UAV company is comprised of a radar platoon and two different UAV platoons, including a human intelligence (HUMINT) platoon. The headquarters and support company provides a high altitude mountain reconnaissance platoon, which is a unique unit within German armed forces, providing reconnaissance capabilities on highest alpine terrain and under harshest climate conditions.

The Mountain Engineer Battalion 8 is structured into a headquarters and support company, two mountain engineer companies and an armoured engineer company. The headquarters and support company has the special skills of a diving squad and a mine-detection-dog platoon. The two mountain engineer companies are equipped with regular and mountain-specific material, including a field cable railway and rotary snowploughs. The armoured company is structured into an armoured engineer platoon, an EOD (explosive ordnance disposal) platoon, a folding dry support bridge platoon and an engineer construction equipment platoon.

The Mountain Support Battalion 8 is structured into a headquarters and support company, three supply companies and a non-active transportation company. The supply companies are dislocated at the brigade's garrisons Bad Reichenhall, Mittenwald and Füssen, where also the battalions' HQ is stationed. Each of them comprises a supply echelon, a maintenance echelon and a transportation platoon.

The Operations and Training Centre for Pack Animals 230 is another special feature of the brigade. Being directly subordinated to the brigade HQ, it guarantees mobility in high alpine terrain and under all possible weather conditions. The company-sized unit has both pack mules and horses to transport mainly equipment and, for special tasks, also soldiers. It comprises three pack animal platoons, a company maintenance section, a blacksmith and a veterinarian team. 
In addition, the German Armed Forces have the Ausbildungsstützpunkt Gebirgs- und Winterkampf (training base for mountain and winter warfare) in MITTENWALD at their disposal. Although this training base is stationed at a brigade garrison location, it is not subordinated to the brigade but to the German Army Infantry School. However, the brigade has a very close and special relationship with this training centre. It provides expertise and vital alpine training opportunities for all the brigade's soldiers. E.g., together with its Austrian counterpart, all army mountain guides and specialized mountain personnel receive their training at this installation (Friedrich K. Jeschonnek, 2015, pp. 78-79).

\section{THE ARMY MOUNTAIN GUIDE ("HEERESBERGFÜHRER")}

The army mountain guides are specifically qualified experts in high altitude mountain warfare. All the brigade's units are equipped with these assets. Being officers or non-commissioned officers (NCOs), they are advising military leaders on all tactical levels during the preparation and execution of military operations in difficult and/or alpine terrain, including high altitudes and extreme climate and weather conditions. The army mountain guides evaluate terrain structures, recommend climbing routes and assess the weather and avalanche situation as a prerequisite for successful military planning and operations. Furthermore, they significantly contribute to the training and improvement of mountain skills of all brigade units. Moreover, they are qualified to lead mountain medical teams in combat and peace-time searchand-rescue missions. Additionally, the army mountain guide, also referred to as a "scout", is qualified to support the deployment of specialized and Special Forces to their mission areas in the mountains, if deemed necessary. The army mountain guide training is one of the longest and hardest in the German Armed Forces. It takes more than a year, has extensive, both winter and summer, training periods and takes place inter alia in Germany, Austria, France and Italy (Matthias Duchscherer, 2013).

\section{MISSIONS}

From 1993 to 1994, the commander of Mountain Infantry Brigade 23, Colonel Holger Kammerhoff took command of $2^{\text {nd }}$ German Contingent UNOSOM II in Belet Uen, Somalia. This mission marked the first deployment of German mountain troops to an overseas theatre after the Second World War. From 1995 to 1996, the brigade deployed soldiers to Croatia as security forces several times. From 1996 to 1999 , some 900 brigade members were deployed to IFOR (Implementation Force), SFOR (Stabilization Force) and "Extraction Force" in the former Yugoslavia. In 2000, the Mountain Infantry Battalion 232 was in charge to train the first joint KFOR/ SFOR (Kosovo Forces/Stabilization Forces) for their mission. From 2002 to 2003 , the KFOR task force headquarters were manned by brigade officers and NCOs. In 2003, the commanders of mountain infantry battalions 232 and 233 commanded battle groups West and East in Kabul, Afghanistan, starting a more than decade-long mission history in this rugged and war-torn country. 
Since 2003, units and separate detachments of Mountain Infantry Brigade 23 have been regularly deployed to several missions in the Balkans, Afghanistan and again Africa. As one of the most experienced combat units of the German Armed Forces, this history will for sure continue. Today, soldiers of the Mountain Infantry Brigade 23 are currently deployed to missions in Iraq, Afghanistan, Mali, Somalia and Kosovo (Editorial office German army, 2014).

\section{BRIGADE BATTLE EXERCISE EDELWEISS 2015}

In 2014, when the ISAF mission concluded, the operating environment of German combat troops, including the Mountain Infantry Brigade 23 changed. The German Armed Forces are now moving from a "forces on mission" approach to a "forces in readiness" approach. For a successful implementation of this transformation, the Mountain Infantry Brigade 23 has to re-enforce mountain warfare training events and exercises. It is a movement "back to the roots".

The Brigade Battle Exercise EDELWEISS, conducted in springtime 2015, was an important element to benchmark the progress of this development. The exercise locations exceeded the brigade's peacetime garrisons and included the Austrian high alpine training area Litzum-Walchen, close to the city of Innsbruck.

Figure 2:

Boarding during

Field Integration

Training

Slika 2:

Vkrcanje med

terenskim

integracijskim usposabljanjem

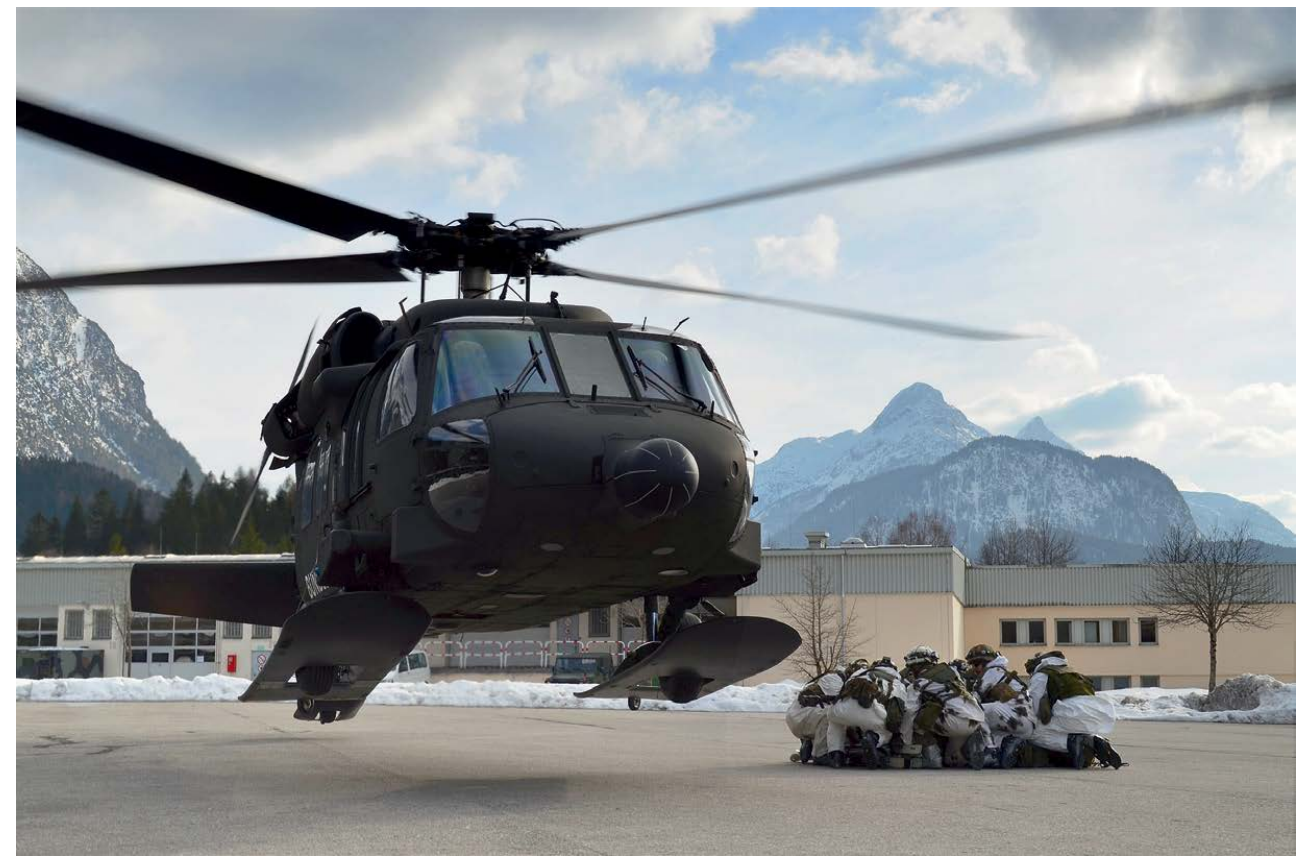


Figure 3:

Support by Pack Animal

Slika 3:

Podpora tovornih živali

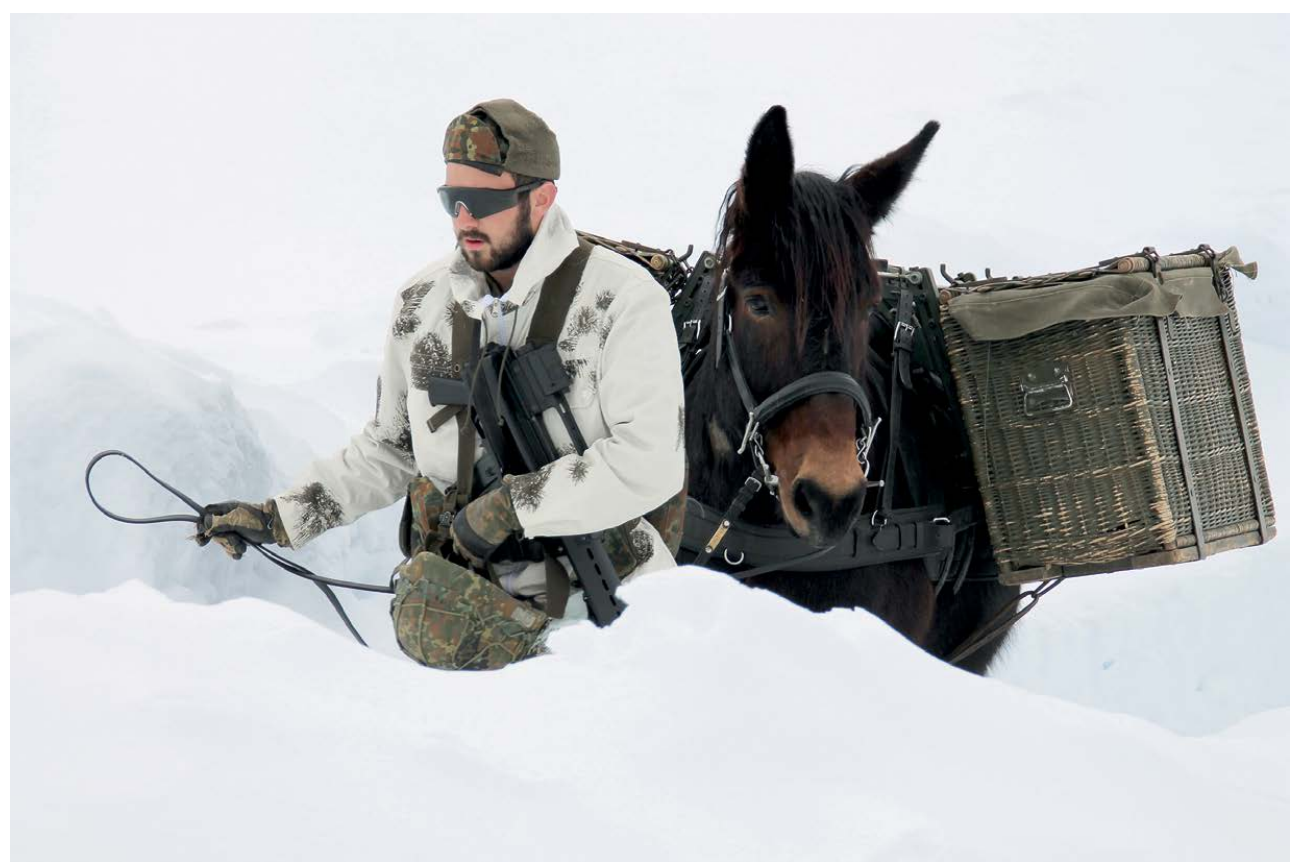

\subsection{Situation}

Opposing forces were operating in an area at heights up to 2500 metres. They allegedly ran a training camp and brought a friendly air defence system under their control.

A battalion task force under the lead of Mountain Infantry Battalion 233 was tasked to repel the enemy forces and to secure or destroy the air defence system. An Austrian company force, derived from the $6^{\text {th }}$ (AUT) Infantry Brigade was part of the task force to intensify the bi-national cooperation between German and Austrian armed forces. This scenario took place as part of a notional European stabilization mission.

\subsection{Mission preparation}

One year before the mission, the Mountain Infantry Battalion 233 received the order to generate troops as response forces for the European Union. According to the notional situation the battalion should be combat ready and take charge of response forces at the beginning of 2015 .

As the situation developed, the battalion task force was activated and got the deployment order. One week prior to STARTEX, all task-force troops were deployed in the vicinity of Mittenwald, home garrison of Mountain Infantry Battalion 233. At that location, the Battalion Task Force 233, including the Austrian company, forces 


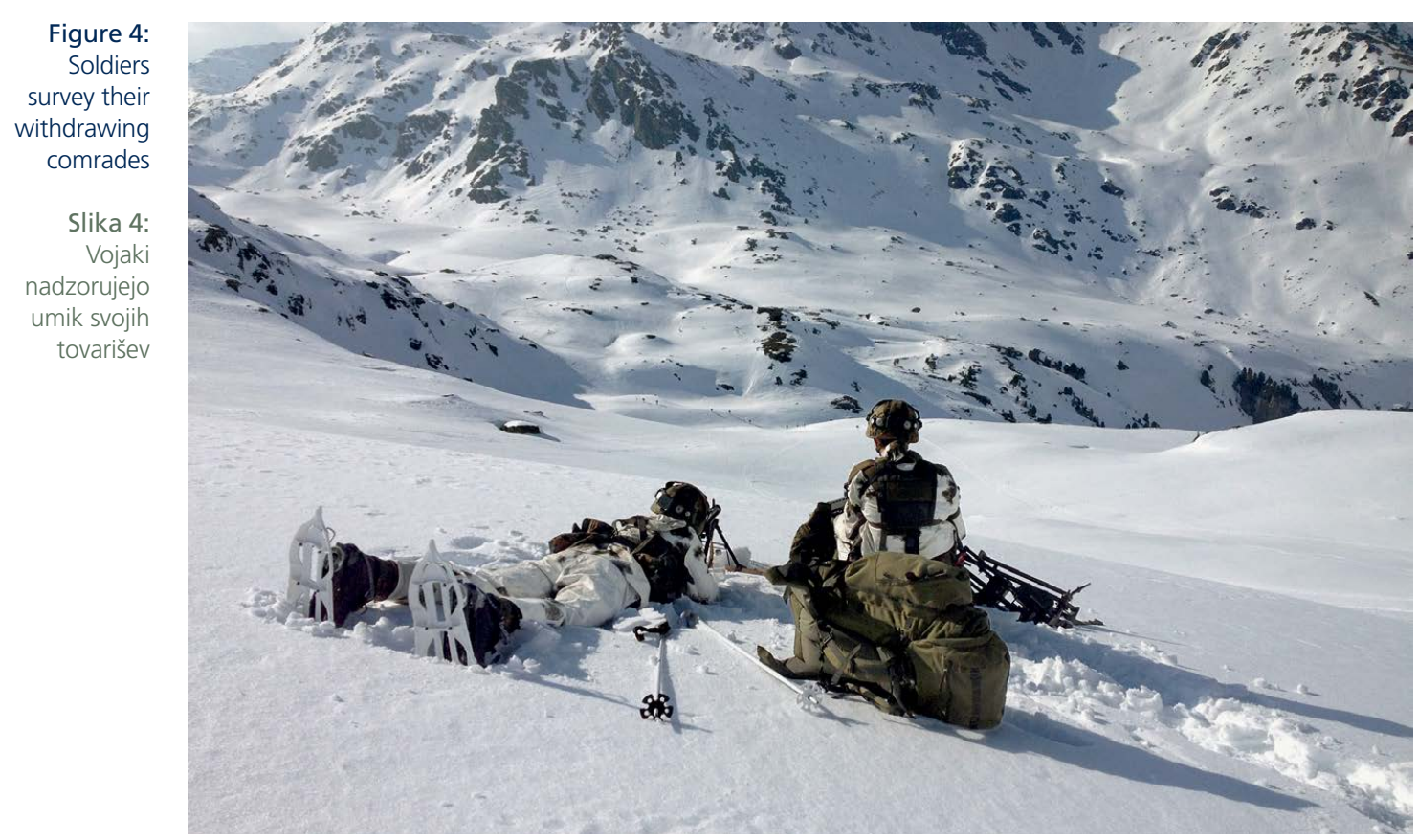

of the Mountain Reconnaissance Battalion 230, Mountain Support Battalion 8 and Mountain Engineer Battalion 8, completed their field integration training.

\subsection{Battle Exercise}

During the field integration training, the high altitude mountain reconnaissance platoon already started to reconnoitre the area of operations. Once the field integration was concluded, the main bulk of the task force deployed as well. Between the departure and the accomplishing of the objective, the battalion task force 233 had to overcome the altitude difference of 1100 metres and to coordinate the attack in two parallel high-alpine valleys within four days. In March, the area of operations had wintry conditions with piles of snow and ice. The temperature fell partly below $-10^{\circ} \mathrm{C}$.

The operation was supported by Austrian Army close air support helicopters and high-trajectory weapons of the Mountain Infantry Battalion 233. These elements of manoeuvre had to be coordinated by the forward air controllers of the task force. Furthermore, light cargo helicopters supported the task force by deploying soldiers and equipment in the area of operations. Nevertheless, most forces were ground-deployed.

The second company of the Mountain Infantry Battalion 232 formed the opposing forces. During the force integration training of the task force, the company prepared 
Figure 5: Support by light cargo helicopter

Slika 5:

Podpora lahkega

tovornega

helikopterja

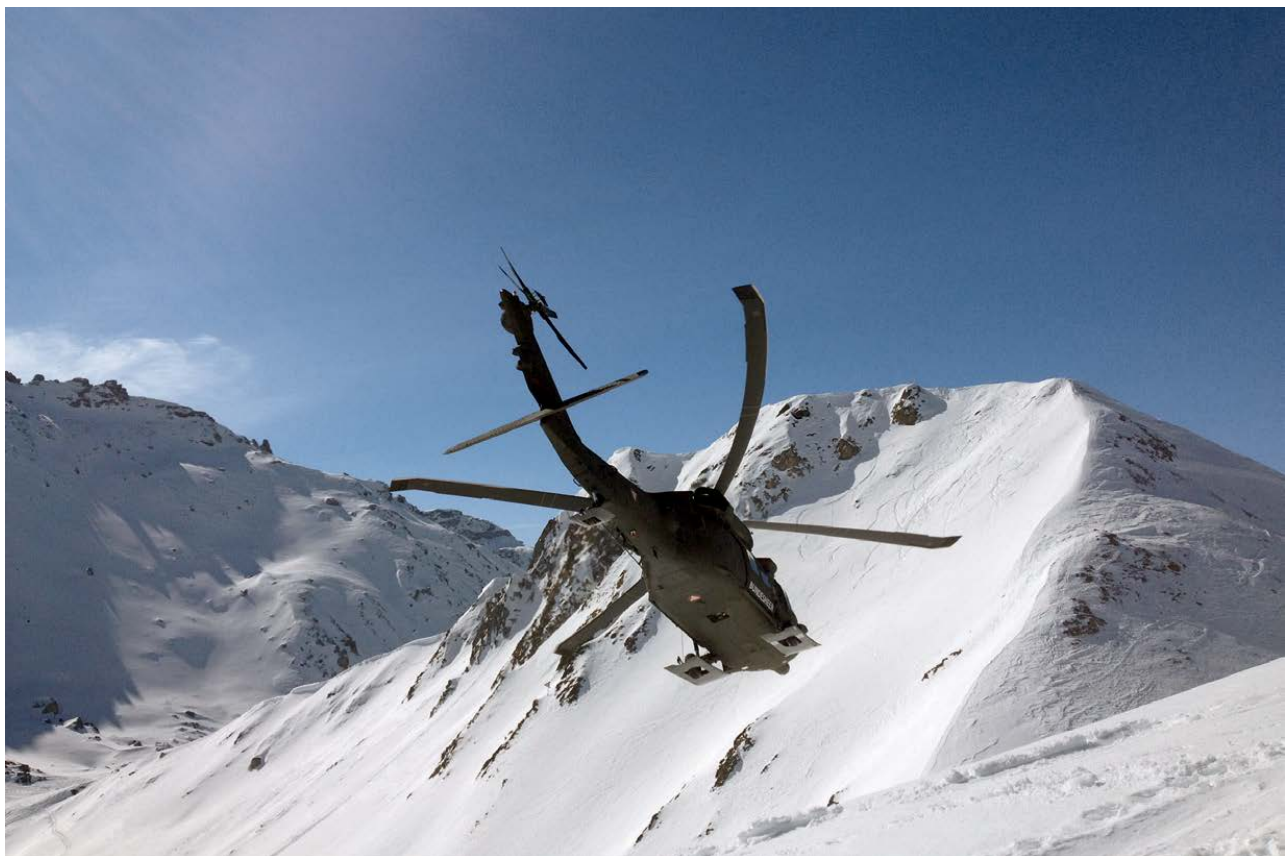

Figure 6: Shooting mortar position

Slika 6: Položaj za streljanje z minometom

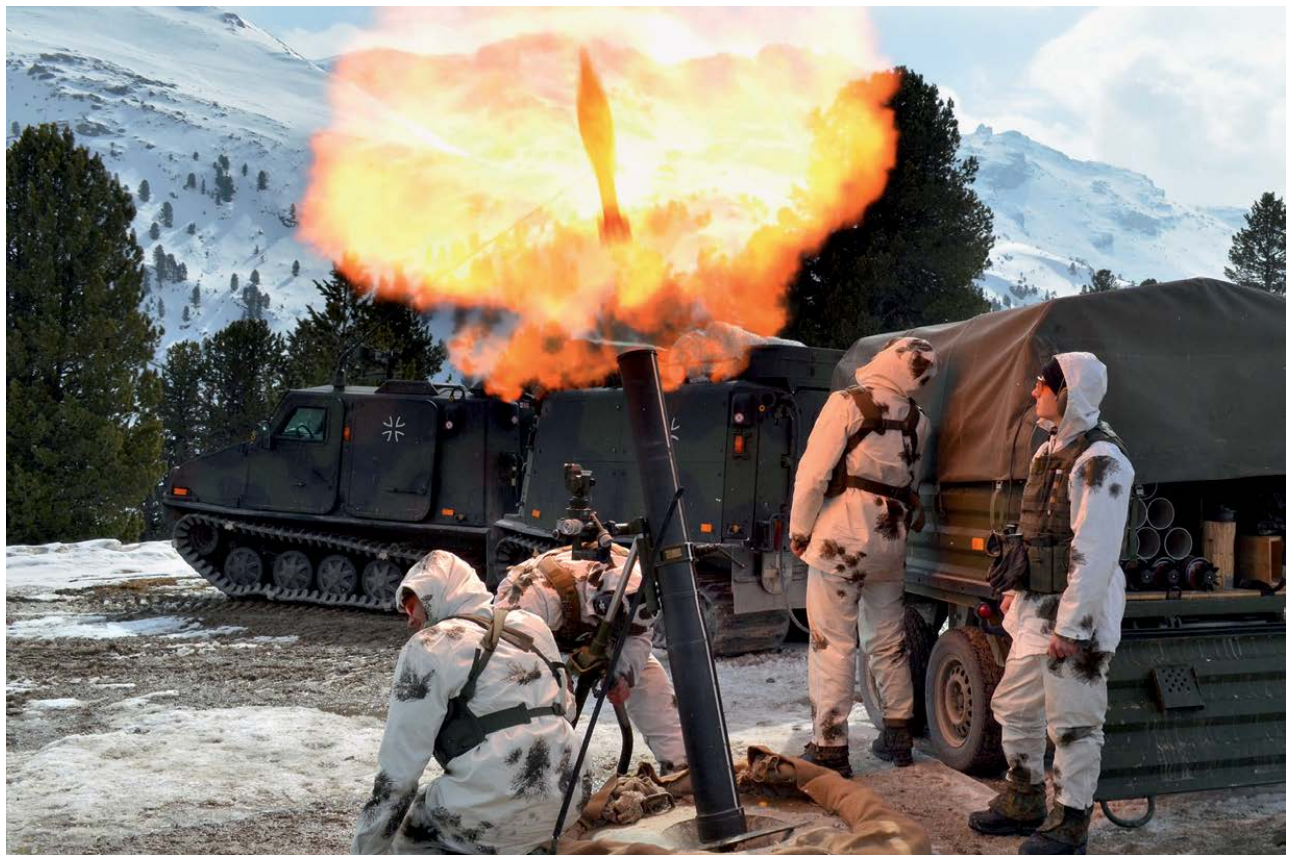


Figure 7: Machine gun in firing

Slika 7: Streljanje z mitraljezom

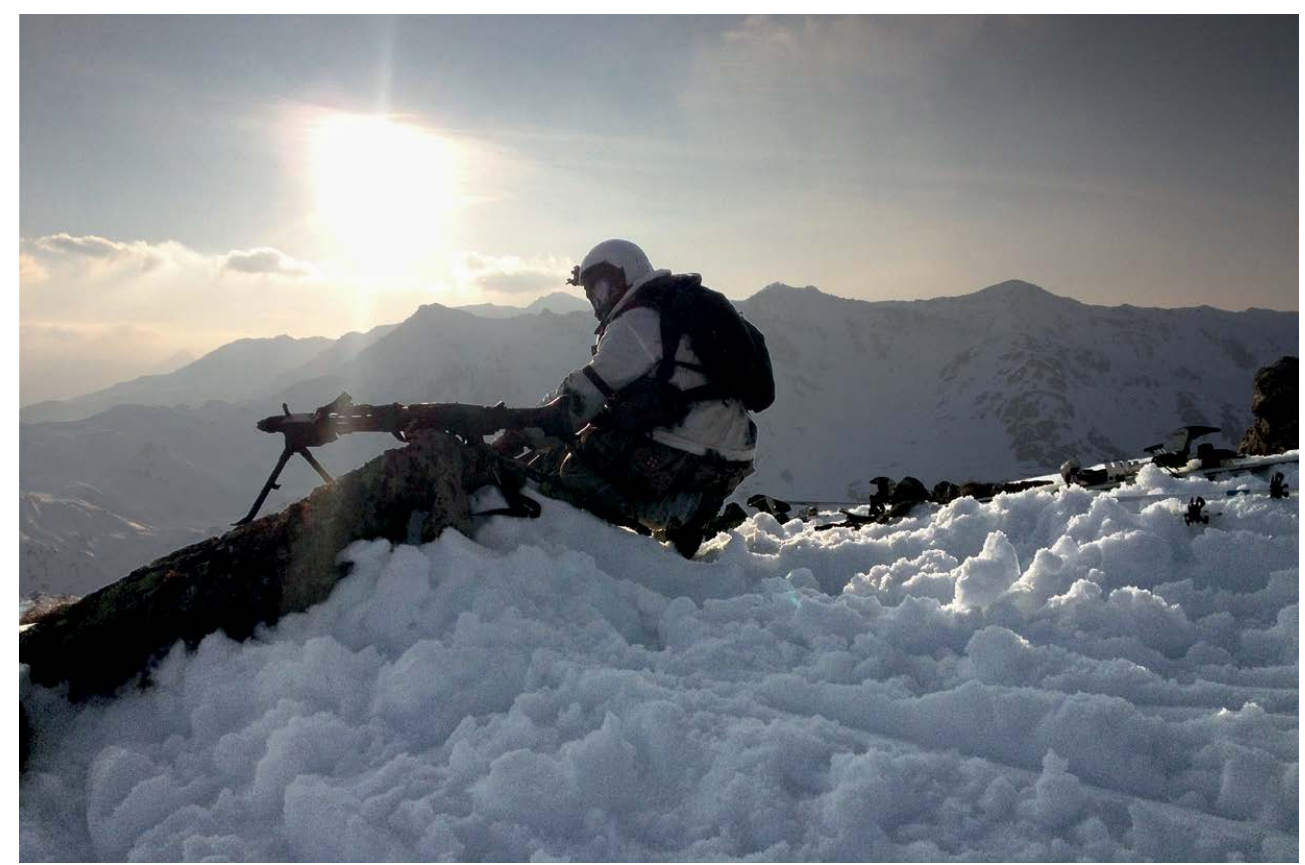

delay and defence operations in the area. Both exercise parties were equipped with the AGDUS duel-simulator training system. Under these circumstances, a realistic battle scenario was given.

\subsection{Summary of the Brigade Combat Exercise EDELWEISS 2015}

About one thousand soldiers participate at the Brigade Combat Exercise EDELWEISS 2015. In this exercise, the brigade trained defence and attack tactics in alpine terrain and under very demanding weather conditions. The complex scenario required the whole spectrum of military mountain warfare in winter, which was perfectly mastered by all exercise participants.

Subsequent to the task force operation, several live-firing exercises and mountainspecific trainings took place. This three week exercise marked the peak of a series of exercise in 2014/15 and will see a continuation in fall 2016 in the same area.

Conclusion The Mountain Infantry Brigade 23 has a multifaceted and eventful history. As one of the first German brigade units after the Second World War, it was established in the early Cold-War era and saw first combat missions after the fall of the Berlin wall. Warfare in rugged, even extreme terrain and non-permissive climate conditions requires specially trained and equipped forces. Throughout all recent developments in military strategy and challenges in the global security environment, it proved to 
be right to contain a unit with unique character and expertise such as the Mountain Infantry Brigade 23.

Over time, the brigade's ability and range grew from pure mountain warfare, to skills in urban warfare, fighting under extreme climate and weather conditions, even mechanized warfare and, of course, mountain rescue skills. With this wide range of capabilities, the brigade is an important mainstay of the German Army for future challenges in the security environment within the framework of collective security systems.

The brigade will maintain an important portion of future tasks in the German Armed Forces and its international allies. The challenge today is to intensify the cooperation at the international level in order to keep and improve the high skill level of mountain warfare. Currently, the Mountain Infantry Brigade 23 cooperates with Austria, France and Poland and is interested in further cooperation with other NATO and EU countries to improve mountain warfare skills and fighting under extreme weather conditions.

\section{Bibliography}

1. Duchscherer, M, 2013. Klettern bis die Finger glühen, http://www.deutschesheer.de/ portal/a/heer/!ut/p/c4/NYzBCsIwEET_aDctLYi3lly8CO1F621NQxNNk7Js9OLHmwrOw PBghsEbFkd6-YXEp0gBrzgZf7y_wVinLQE_JNgSIZBx748RGeJDjWlV1gZjph3jZf2YLJkU re5ah-JILkySGLbGEvcnMpQE_46Qq3atW_VV9DoPuzkPbNPrUj7ita_cFom-v7A!!!, 25 November, 2103

2. Editorial office German Army, 2014. Gebirgsjägerbrigade 23 - Geschichte, http://www. deutschesheer.de/portal/a/heer/!ut/p/c4/DcZJDoAgDADAt_iB1uXmzV-oN5amVAkSaDDx 9ZK5DJ7YJdOEjcqTTMQdDyerfSEQFfBCqWpVmMb8eWnA0TMw2YttEZ6X_uqCuKCEd6GH28qvfk!/, 19 December, 2014.

3. Jeschonnek, F. K., 2015. Historie deutscher Gebirgstruppen. Bonn/Berlin: HardthöhenKurier, $p$ 79, 2015.

4. Jeschonnek, F. K., 2015. Bereit zum Einsatz in extremen klimatischen und geografischen Bedingungen: Die Gebirgstruppe der Bundeswehr. Bonn/Berlin: Hardthöhen-Kurier, pp. 78-83, 2015.

\section{Reference of figures}

Figure 1:http://www.deutschesheer.de/portal/a/heer/!ut/p/c4/04 SB8K8xLLM9MSSzPy8xBz9CP3I5EyrpHK9jNTUIr2UzNS84pLiEj1Dg4KqlMwyvfSclHS99NSkrPSkosx0I2OwgH5BtqMiAKPZPec!/,

Figure 2, 3 and 5: Hauptman Sebastian Zäch,

Figure 4, 6 and 7: Oberstleutnant Johannes Schwegler 
Slikovno gradivo

\section{Photos}


Priloga 1:

Stanje v SV

Appendix 1:

Situation

in the SAF
凶

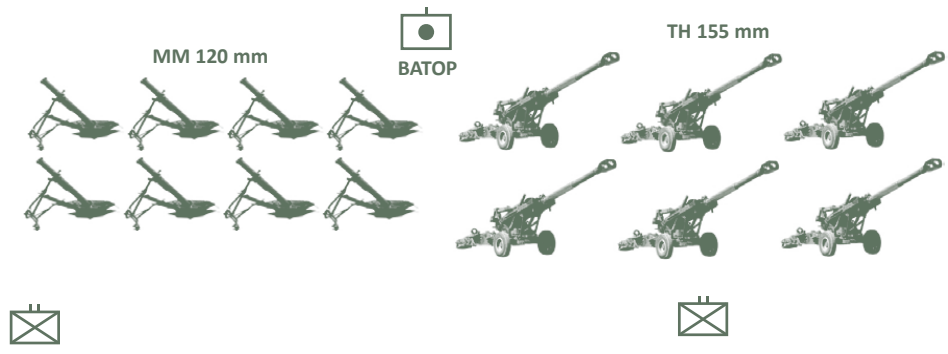

艾

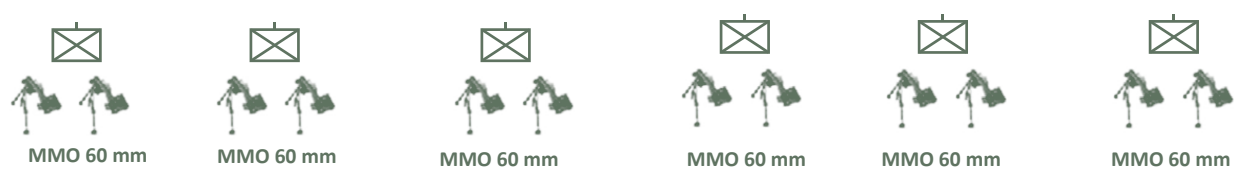

Priloga 2:

Predlog razvoja

Appendix 2:

Development proposal

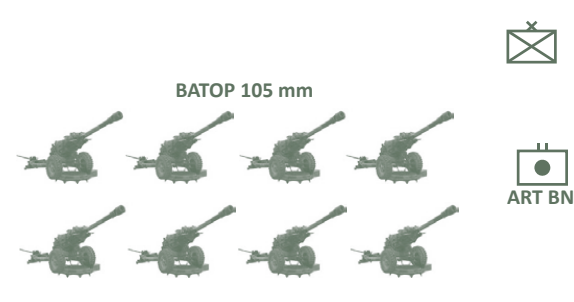

芉

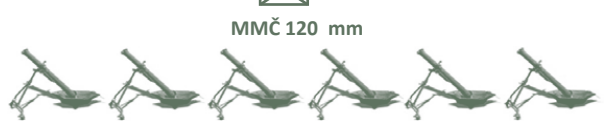

㐫

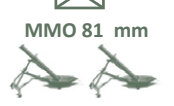

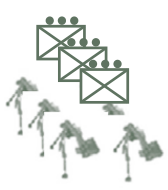

MMO $60 \mathrm{~mm}$
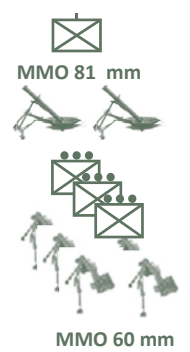

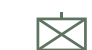

mino

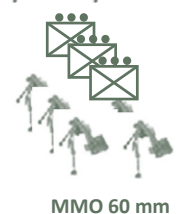

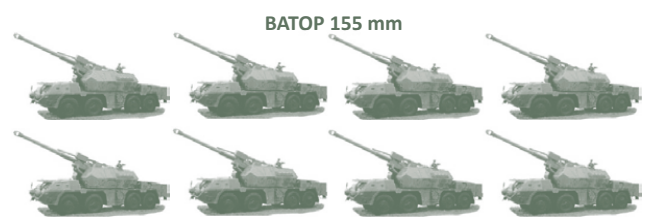

芉

MMČ $120 \mathrm{~mm}$

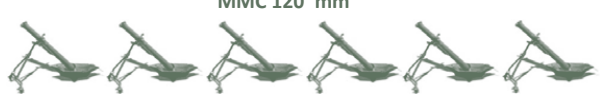

㐫

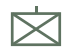

㐫
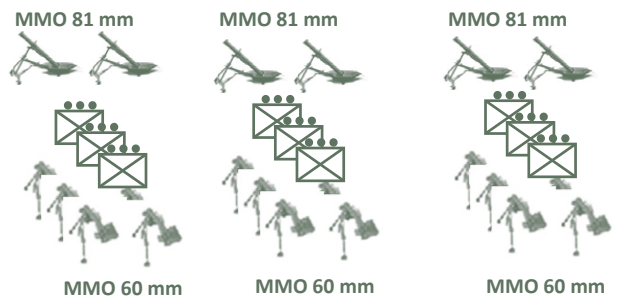


\section{Priloga 3:}

Predlog izboljšanja sedanjega stanja Appendix 3: Proposal for the improvement of the current situation
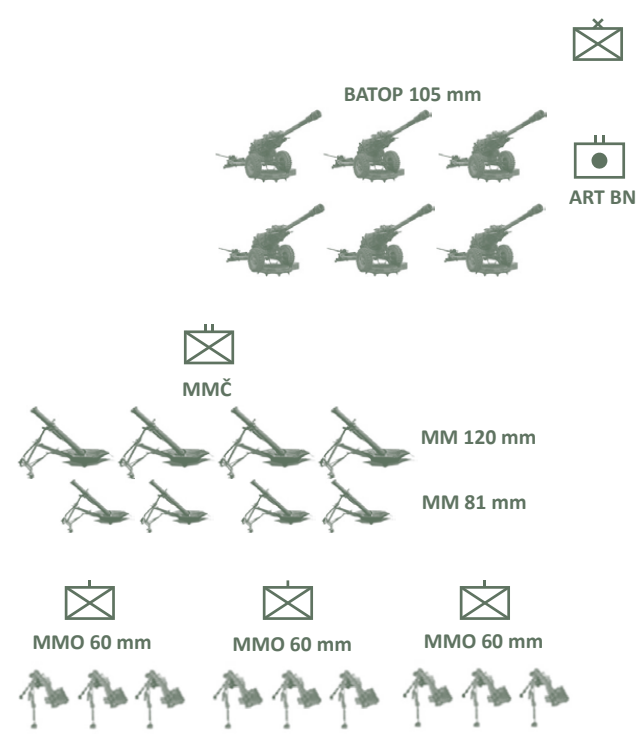
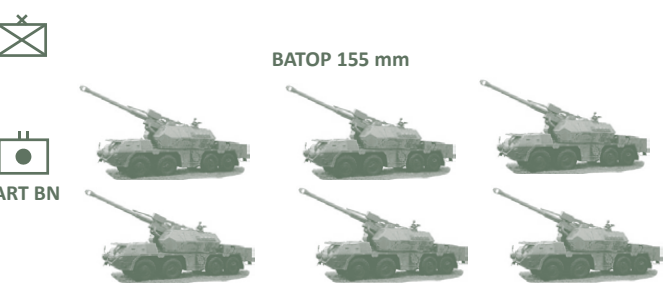

凶
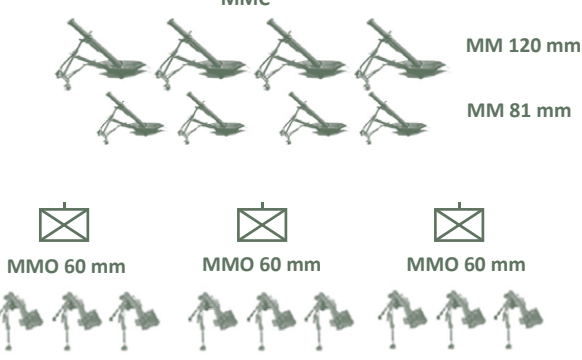

Priloga 4:

Pehotna brigada kopenske vojske ZDA

Appendix 4: Infantry Brigade, US Army
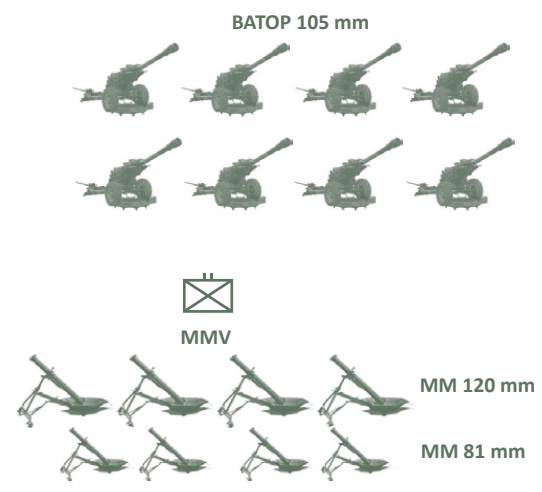

㐫

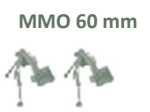

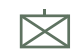

MMO $60 \mathrm{~mm}$

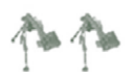

㐫

MMO $60 \mathrm{~mm}$

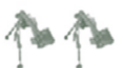

$凶$
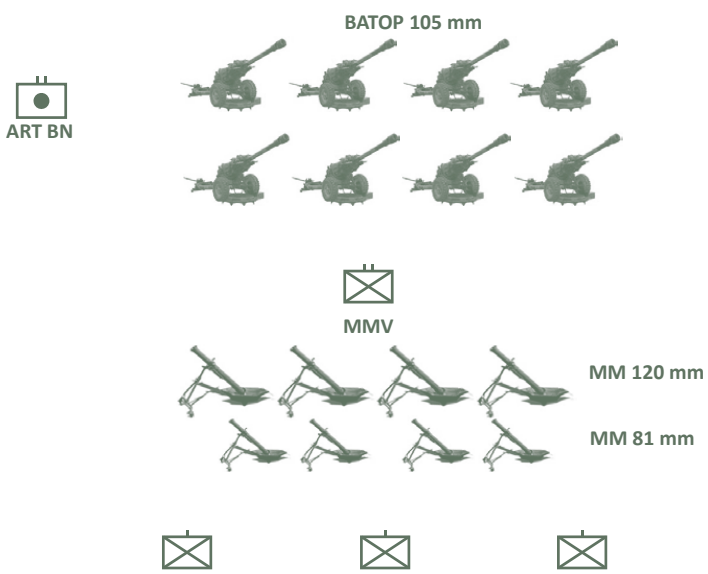

MMO $60 \mathrm{~mm}$

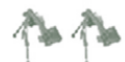

MMO $60 \mathrm{~mm}$

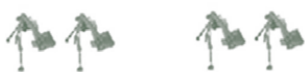




\section{Priloga 5:}

Brigada

britanske

kopenske vojske

Appendix 5:

Brigade, British

Army $\ddot{凶}$

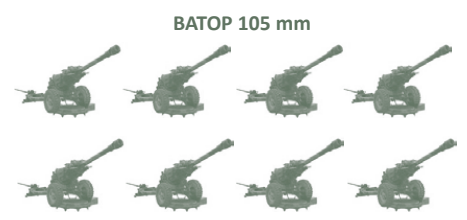

$\underset{\text { ART BN }}{\bullet}$

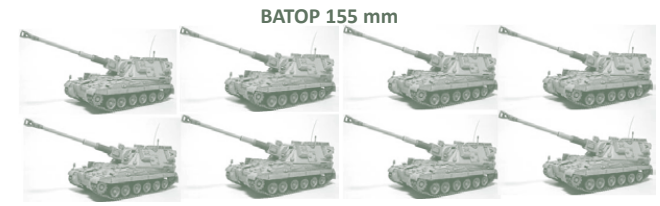

凶
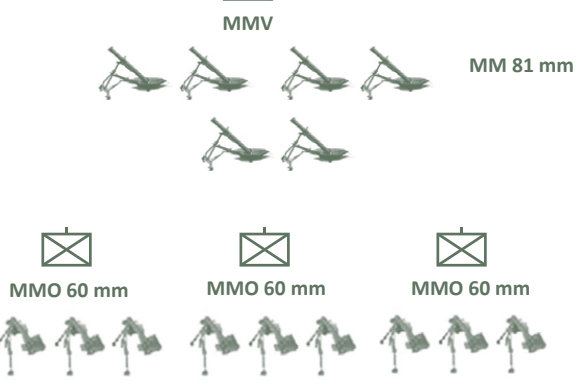

Priloga 6:

Brigada

kopenske vojske

Ruske federacije

Appendix 6:

Brigade,

Ground Forces

of the Russian

Federation
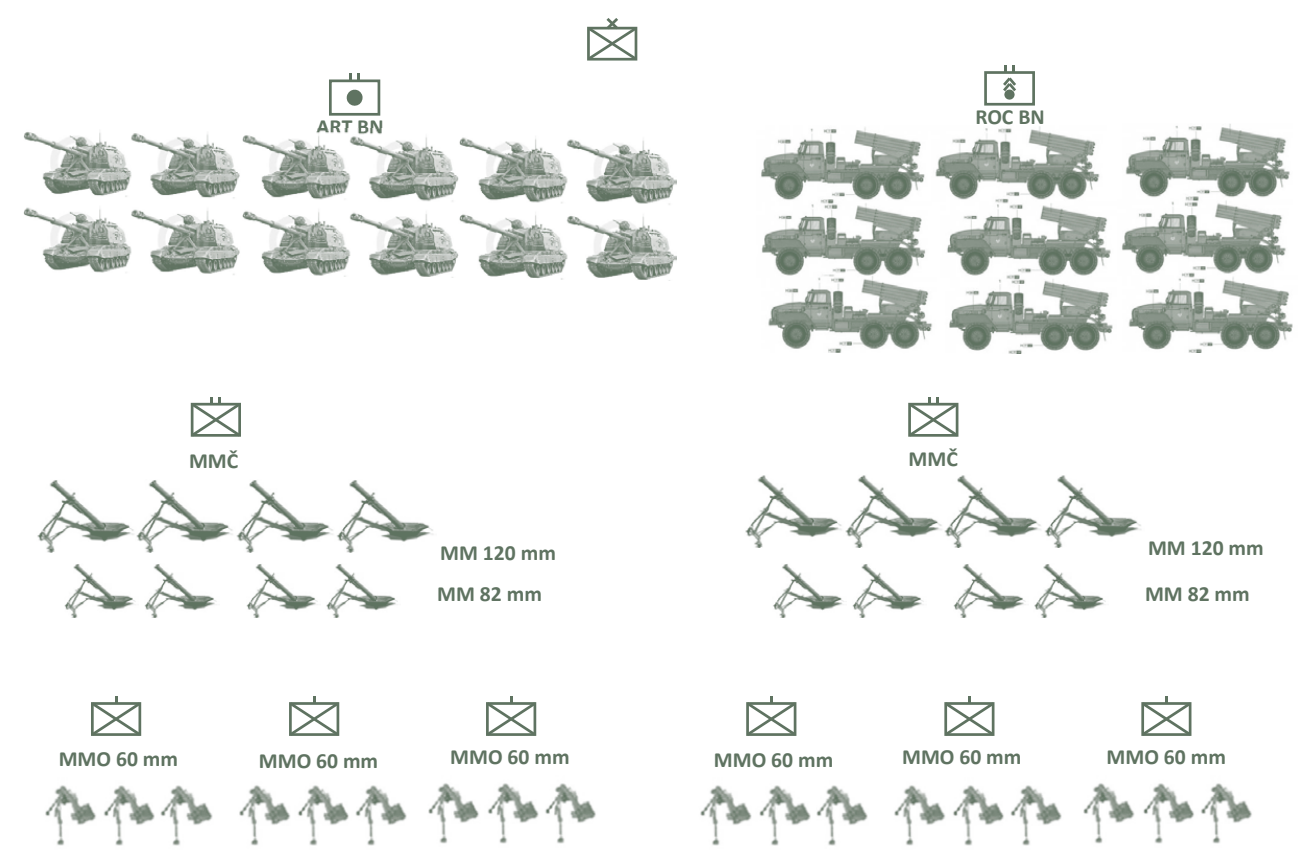
Avtorji

Authors 


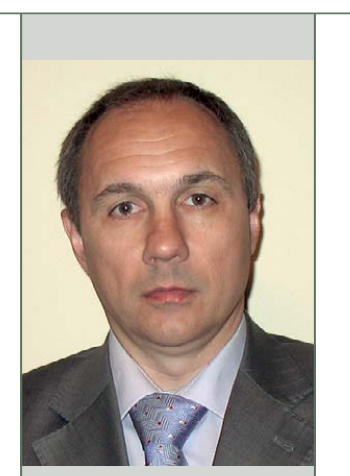

Pavel Vuk

Mag. Pavel Vuk je univerzitetni diplomirani politolog in magister politoloških znanosti, oba študija je končal na Fakulteti za družbene vede v Ljubljani. Na Ministrstvu za obrambo je zaposlen od leta 1992. V obdobju 2011-2015 je vodil Sektor za strateško planiranje v okviru Direktorata za obrambno politiko, od leta 2016 deluje v Centru vojaških šol na Katedri vojaških ved kot učitelj za strategijo in operatiko. Posebno dejaven je na področjih nacionalne varnosti in obrambe, mednarodne varnosti in obrambnega načrtovanja. Je avtor številnih strokovnih člankov s teh področij v slovenskih publikacijah.

Pavel Vuk, MSc, holds bachelor's and master's degrees in Political Science, both from the Faculty of Social Sciences in Ljubljana. He has been employed at the Ministry of Defence since 1992. Between 2011 and 2015, he headed the Strategic Planning Division within the Defence Policy Directorate and, since 2016, he has been working at the Chair of Military Sciences of the Military Schools Centre as a teacher of strategy and operational art. He is particularly engaged in the areas of national security and defence, international security and defence planning. He has authored numerous scientific articles on the aforementioned subjects published in Slovenian publications.

Polkovnik dr. Mehmedin Tahirović je leta 1981 diplomiral na vojaški akademiji v Beogradu. Leta 2005 je magistriral na Pravni fakulteti v Podgorici in leta 2011 doktoriral na Univerzi v Mostarju. Kot docent predava na Univerzi Donja Gorica v Podgorici in na Policijski akademiji v Danilovgradu. Trenutno je zaposlen kot vodja Službe za odnose z javnostmi in protokol Ministrstva za obrambo Črne gore.

Colonel Mehmedin Tahirović PhD, graduated from the Military Academy in Belgrade 1981. He received his Master's degree at the Faculty of Law in Podgorica 2005, and his PhD at the University of Mostar in Bosnia and Herzegovina in 2011. As assistant professor, he is engaged at the University of Donja Gorica in Podgorica and Police Academy in Danilovgrad. His current position is Head of Service for Public Relations and Protocol at Ministry of Defence of Montenegro. 


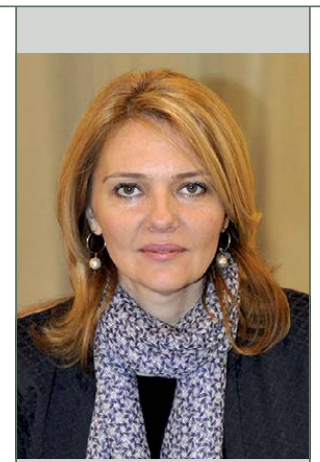

Olivera Injac

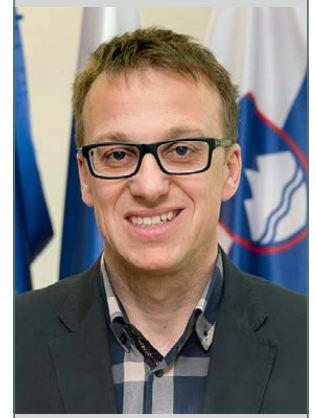

Gregor Zupan
Dr. Olivera Injac je docentka in predstojnica Katedre za varnostne študije na Fakulteti za humanistične študije Univerze Donja Gorica v Podgorici. Pred tem je bila med letoma 1999 in 2008 zaposlena na Ministrstvu za obrambo Črne gore. Septembra leta 2008 se je kot redno zaposlena članica fakultete posvetila akademski karieri na Fakulteti za humanistične študije. Je avtorica številnih znanstvenih knjig, člankov in prispevkov na področjih nacionalne in mednarodne varnosti, varnostne kulture, terorizma itn.

Olivera Injac, PhD, is Assistant Professor and Chair in Security Studies, at the Faculty of Humanistic Studies University of Donja Gorica, Podgorica. Prior to that, she worked for the Ministry of the Interior of Montenegro from 1999 to 2008. In September 2008, she started with academic career at the Faculty of Humanistic Studies, as a full-time faculty member. She is author of many scientific books, chapters, articles and papers from the field od national and international security, security culture, terrorism, etc.

Gregor Zupan je diplomiral na študijskem programu politologije na Fakulteti za družbene vede Univerze v Ljubljani. Končuje magistrski študij kadrovskega menedžmenta. Po nekajletnih izkušnjah v zasebnem sektorju je od septembra 2005 zaposlen v Direktoratu za obrambno politiko na Ministrstvu za obrambo, in sicer na področju mednarodnega sodelovanja. Trenutno je vodja oddelka za obrambo multilateralo, v katerega pristojnost spadajo dvostransko, regionalno in večstransko sodelovanje, razoroževanje in nadzor nad oboroževanjem ter obrambna diplomacija. Je udeleženec več mednarodnih delavnic, konferenc in seminarjev.

Gregor Zupan graduated in Political Science from the Faculty of Social Sciences in Ljubljana. He is currently completing his master studies in human resource management. Since September 2005, he has been working in the field of international cooperation at the Defence Policy Directorate of the Ministry of Defence following a several-years career in the private sector. Currently, he heads the Department of Multilateral Defence Cooperation, which is in charge of bilateral, regional and multilateral cooperation, disarmament and arms control, as well as defence diplomacy. He has participated in a large number of international workshops, conferences and seminars. 


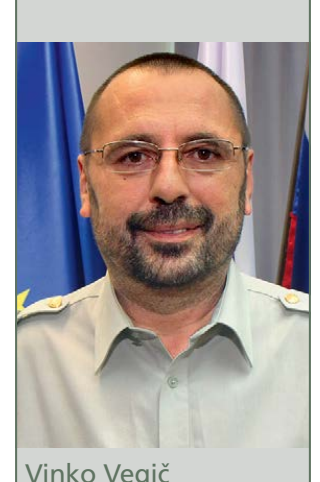

Vinko Vegič

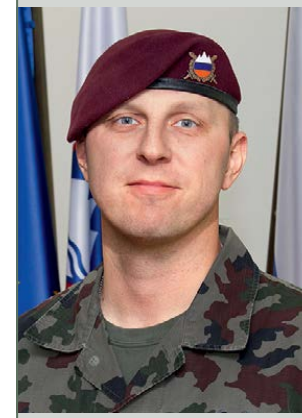

Viktor Potočnik

Višji vojaški uslužbenec XIV. razreda dr. Vinko Vegič je doktoriral iz obramboslovnih znanosti. Bil je raziskovalec in predavatelj na Katedri za obramboslovje na Fakulteti za družbene vede. Področja njegovega raziskovalnega in pedagoškega dela so nacionalna in mednarodna varnost, sodobne varnostne strategije ter vojaške organizacije. V Slovenski vojski je zaposlen od leta 2008. Do leta 2013 je delal v vojaškem izobraževalnem sistemu, bil je tudi načelnik Katedre za nacionalno obrambo, trenutno pa dela v Združenem sektorju za strateško planiranje Generalštaba Slovenske vojske.

Senior Military Specialist, Class XIV, Vinko Vegič, PhD, holds a PhD in Defence Studies. He has worked as a researcher and lecturer at the Chair of Defence Studies at the Faculty of Social Sciences. The areas of his research and educational work include national and international security, modern security strategies and military organizations. He has worked in the Slovenian Armed Forces (SAF) since 2008. Until 2013, he was engaged in the military education system, also as Head of the Chair of National Security. Currently, he works at the Joint Strategic Planning Division at SAF General Staff.

Major mag. Viktor Potočnik je v Slovenski vojski zaposlen od leta 2001. Opravljal je naloge poveljnika motoriziranega voda, minometne čete in motorizirane čete $\mathrm{v}$ mednarodnih operacijah in na misijah ter načelnika S-3 pehotne brigade Slovenske vojske. Udeležil se je treh mirovnih operacij in misij, opravil je več izobraževanj in usposabljanj v tujini, predvsem za ognjeno podporo. Leta 2011 je končal višještabno šolanje na CGSC v bazi Fort Leavenworth v ZDA in pridobil naziv Master of Military Arts and Science. Trenutno dela v oddelku J-5 na Generalštabu Slovenske vojske.

Major Viktor Potočnik, MsC, has worked in the SAF since 2001. So far, he has performed duties of a Motorised Platoon Commander, Mortar Company and Motorised Company Commander in international operations and missions, and Chief, S-3 in SAF Infantry Brigade. He has been deployed to three operations and missions, and has attended several education and training programmes abroad, mainly in the field of fire support. In 2011, he completed Senior Staff Course and CGSC, Fort Leavenworth, USA and obtained the title Master of Military Arts and Science. Currently, he works in J-5 at SAF General Staff. 


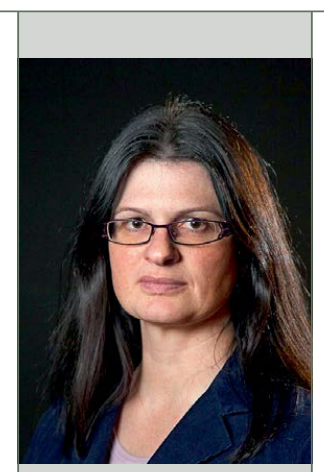

Maja Garb

Doc. dr. Maja Garb je doktorica znanosti iz obramboslovja, zaposlena na Fakulteti za družbene vede Univerze v Ljubljani. Ukvarja se s sociologijo vojaške organizacije, civilno-vojaškimi odnosi, mirovnimi operacijami in misijami, analizami sodobnih konfliktov ter vodenjem v vojski. Je nosilka predmetov obrambni menedžment in analiza sodobnih konfliktov ter praktičnih predmetov na programu politologija - obramboslovje. Najbolj dejavna je pri raziskovalnih projektih, povezanih s človeškim dejavnikom v vojski, z mirovnimi operacijami in misijami ter javnomnenjskimi raziskavami. Od leta 2009 je skrbnica magistrskega programa za obramboslovje.

Assist. Prof. Maja Garb, PhD, holds a PhD in Defence Studies from the Faculty of Social Sciences in Ljubljana. She deals with the sociology of military organizations, civil-military relations, peace operations, analysis of contemporary conflicts and management in the armed forces. She is chief lecturer in Defence Management, and Analysis of Contemporary Conflicts, and teaches practical classes in the programme Political Science - Defence Studies. She is most actively involved in research projects related to the human factor in the military, peace operations, and public opinion polls. Since 2009, she has been managing the Master's program of Defence Studies.

Stotnik Andreas Hauptmann Kaiser se je v nemški vojski zaposlil leta 2006. Diplomiral je iz poslovne administracije na univerzi Helmut Schmidt v Hamburgu, eni izmed dveh univerz nemških oboroženih sil. Od septembra 2014 je pripadnik 23. brigade gorske pehote, $\mathrm{v}$ kateri $\mathrm{v}$ poveljstvu brigade deluje kot častnik za logistiko. Kot častnik za načrtovanje in nadzor je sodeloval tudi na brigadni vaji Edelweiss 2015. Leta 2014 je bil kot namestnik poveljnika čete za poveljevanje in podporo napoten na misijo Kforja.

Captain Andreas Hauptmann Kaiser joined the Mountain Infantry Brigade 23 in September 2014. He serves at the brigade $H Q$ as a logistics officer and has been one of the planning and controlling officers at the Brigade Battle Exercise EDELWEISS 2015. He was deployed to KFOR (Kosovo Forces) mission in 2014 as deputy commander of the headquarters and support company. Hauptmann joined the German Armed Forces in 2006. He holds a bachelor's degree in business administration from the Helmut-Schmidt-Universität in Hamburg, one of the two German Armed Forces universities. 


\section{Navodila avtorjem za oblikovanje prispevkov Instructions for the authors of papers}




\section{NAVODILA AVTORJEM ZA OBLIKOVANJE PRISPEVKOV ZA SODOBNE VOJAŠKE IZZIVE IN VOJAŠKOŠOLSKI ZBORNIK}

\section{Vsebinska navodila}

Splošno

Sodobni vojaški izzivi je interdisciplinarna znanstveno-strokovna publikacija, ki objavlja prispevke o aktualnih temah, raziskavah, znanstvenih in strokovnih razpravah, tehničnih ali družboslovnih analizah $\mathrm{z}$ varnostnega, obrambnega in vojaškega področja.

Vojaškošolski zbornik je vojaškostrokovna in informativna publikacija, namenjena izobraževanju in obveščanju o dosežkih ter izkušnjah na področju vojaškega izobraževanja, usposabljanja in izpopolnjevanja.

Kaj objavljamo?

Objavljamo prispevke v slovenskem jeziku s povzetki, prevedenimi v angleški jezik, in po odločitvi uredniškega odbora prispevke v angleškem jeziku s povzetki, prevedenimi v slovenski jezik.

Objavljamo prispevke, ki še niso bili objavljeni ali poslani v objavo drugi reviji. Pisec je odgovoren za vse morebitne kršitve avtorskih pravic. Če je bil prispevek že natisnjen drugje, poslan v objavo ali predstavljen na strokovni konferenci, naj to avtor sporočiti uredniku in pridobiti soglasje založnika (če je treba) ter navesti razloge za ponovno objavo.

\section{Tehnična navodila}

Omejitve dolžine prispevkov

Recenzije
Prispevki naj obsegajo 16 strani oziroma 30.000 znakov s presledki (avtorska pola), izjemoma najmanj 8 strani oziroma 15.000 znakov ali največ 24 strani oziroma 45.000 znakov.

Prispevki se recenzirajo. Recenzija je anonimna. Glede na oceno recenzentov uredniški odbor ali urednik prispevek sprejme, če je treba, zahteva popravke ali ga zavrne. Pripombe recenzentov avtor vnese v prispevek.

Zaradi anonimnega recenzentskega postopka je treba prvo stran in vsebino oblikovati tako, da identiteta avtorja ni prepoznavna.

Avtor ob naslovu prispevka napiše, v katero kategorijo po njegovem mnenju in glede na klasifikacijo v COBISS spada njegov prispevek. Klasifikacija je dostopna na spletni strani revije in pri odgovornem uredniku. Končno klasifikacijo določi uredniški odbor. 
Lektoriranje Lektoriranje besedil zagotavlja OE, pristojna za založniško dejavnost. Lektorirana besedila se avtorizirajo.

Prevajanje Prevajanje besedil ali povzetkov zagotavlja OE, pristojna za prevajalsko dejavnost oziroma Šola za tuje jezike Centra vojaških šol.

Navajanje Navajanje avtorjev je skrajno zgoraj, levo poravnano.

avtorjev Primer:

prispevka Ime 1 Priimek 1,

Ime 2 Priimek 2

V opombi pod črto se za slovenske avtorje navede, iz katere ustanove prihajajo. Pri tujih avtorjih je treba navesti tudi ime države.

Naslov

Navedbi avtorjev sledi naslov prispevka. Črke v naslovu so velike 16 pik, natiprispevka snjene krepko, besedilo naslova pa poravnano na sredini.

Povzetek Prispevku mora biti dodan povzetek, ki obsega največ 1200 znakov (20 vrstic). Povzetek naj na kratko opredeli temo prispevka, predvsem naj povzame rezultate in ugotovitve. Splošne ugotovitve in misli ne spadajo v povzetek, temveč v uvod.

Povzetek Avtorji morajo oddati tudi prevod povzetka v angleščino. Tudi za prevod povzetka v angleščini velja omejitev do 1200 znakov (20 vrstic).

Ključne besede

Besedilo

\section{Kratka} predstavitev avtorjev
Ključne besede (3-5, tudi v angleškem jeziku) naj bodo natisnjene krepko in $\mathrm{z}$ obojestransko poravnavo besedila.

Avtorji naj oddajo svoje prispevke na papirju formata A4, s presledkom med vrsticami 1,5 in velikostjo črk 12 pik Arial. Na zgornjem in spodnjem robu naj bo do besedila približno $3 \mathrm{~cm}$, levi rob naj bo širok $2 \mathrm{~cm}$, desni pa $4 \mathrm{~cm}$. Na vsaki strani je tako približno 30 vrstic s približno 62 znaki. Besedilo naj bo obojestransko poravnano, brez umikov na začetku odstavka.

Avtorji morajo pripraviti kratko predstavitev svojega strokovnega oziroma znanstvenega dela. Predstavitev naj ne presega 600 znakov (10 vrstic, 80 besed). Če je avtorjev več, se predstavi vsak posebej, čim bolj zgoščeno. Avtorji naj besedilo umestijo na konec prispevka po navedeni literaturi. 
Strukturiranje besedila
Posamezna poglavja $\mathrm{v}$ besedilu naj bodo ločena s samostojnimi podnaslovi in ustrezno oštevilčena (členitev največ na 4 ravni).

Primer:

1 Uvod

2 Naslov poglavja (1. raven)

2.1 Podnaslov (2. raven)

2.1.1 Podnaslov (3. raven)

2.1.1.1 Podnaslov (4. raven)
Oblikovanje seznama literature
Navajanje virov z interneta
V seznamu literature je treba po abecednem redu navesti le avtorje, na katere se sklicujete $\mathrm{v}$ prispevku, celotna oznaka vira pa mora biti skladna s harvardskim načinom navajanja. Če je avtorjev več, navedemo vse, kot so navedeni na izvirnem delu.

Primeri:

a) knjiga:

Priimek, ime (lahko začetnica imena), letnica. Naslov dela. Kraj: Založba.

Na primer:Urlich, W., 1983. Critical Heuristics of Social Planning. Chicago: University of Chicago Press.

b) zbornik:

Samson, C., 1970. Problems of information studies in history. V S. Stone, ur. Humanities information research. Sheffield: CRUS, 1980, str./pp. 44-68. Pri posameznih člankih v zbornikih na koncu posameznega vira navedemo strani, na katerih je članek, na primer:

c) članek $v$ reviji

Kolega, N., 2006. Slovenian coast sea flood risk. Acta geographica Slovenica. 46-2, str. $143-167$.

Vse reference se začenjajo enako kot pri natisnjenih virih, le da običajnemu delu sledi še podatek o tem, kje na internetu je bil dokument dobljen in kdaj. Podatek o tem, kdaj je bil dokument dobljen, je pomemben zaradi pogostega spreminjanja www okolja.

Urlich, W., 1983. Critical Heuristics of Social Planning. Chicago: University of Chicago Press, str. 45-100. http://www.mors.si/index.php?id=213, 17. 10. 2008. Pri navajanju zanimivih internetnih naslovov v besedilu (ne gre za navajanje posebnega dokumenta) zadošča navedba naslova (http://www.vpvs.uni-lj.si). Posebna referenca na koncu besedila $\mathrm{v}$ tem primeru ni potrebna. 
Sklicevanje na vire

Slike, diagrami in tabele
Opombe pod črto

Kratice

Format zapisa prispevka
Pri sklicevanju na vire med besedilom navedite le priimek prvega avtorja in letnico izdaje. Primer: ... (Smith, 1997) ...

Če dobesedno navajate del besedila, ga ustrezno označite z narekovaji, v oklepaju pa poleg avtorja in letnice navedite stran besedila, iz katerega ste navajali.

Primer: ... (Smith, 1997, str. 15) ...

Pri povzemanju drugega avtorja napišemo besedilo brez narekovajev, v oklepaju pa napišemo, da gre za povzeto besedilo. Primer: (po Smith, 1997, str. 15). Če avtorja navajamo $\mathrm{v}$ besedilu, $\mathrm{v}$ oklepaju navedemo samo letnico izida in stran (1997, str. 15).

Slike, diagrami in tabele v prispevku naj bodo v posebej pripravljenih datotekah, ki omogočajo lektorske popravke. V besedilu mora biti jasno označeno mesto, kamor je treba vnesti sliko. Skupna dolžina prispevka ne sme preseči dane omejitve.

Če avtor iz tehničnih razlogov grafičnih dodatkov ne more oddati v elektronski obliki, je izjemoma sprejemljivo, da slike priloži besedilu. Avtor mora $\mathrm{v}$ tem primeru na zadnjo stran slike napisati zaporedno številko in naslov, $\mathrm{v}$ besedilu pa pustiti dovolj prostora zanjo. Prav tako mora biti besedilo opremljeno $\mathrm{z}$ naslovom in številčenjem slike. Diagrami se štejejo kot slike. Vse slike in tabele se številčijo. Številčenje poteka enotno in ni povezano s številčenjem poglavij. Naslov slike je naveden pod sliko, naslov tabele pa nad tabelo. Navadno je v besedilu navedeno vsaj eno sklicevanje na sliko ali tabelo. Sklic na sliko ali tabelo je: ... (slika 5) ... (tabela 2) ...

Primer slike: $\quad$ Primer tabele:

Tabela 2: Naslov tabele

Slika 5: Naslov slike

Številčenje opomb pod črto je neodvisno od strukture besedila in se v vsakem prispevku začne s številko 1. Posebej opozarjamo avtorje, da so opombe pod črto namenjene pojasnjevanju misli, zapisanih v besedilu, in ne navajanju literature.

Kratice naj bodo dodane v oklepaju, ko se okrajšana beseda prvič uporabi, zato posebnih seznamov kratic ne dodajamo. Za kratico ali izraz v angleškem jeziku napišemo najprej slovensko ustreznico, v oklepaju pa angleški izvirnik in morebitno angleško kratico.

Uredniški odbor sprejema prispevke, napisane z urejevalnikom besedil MS Word, izjemoma tudi v besedilnem zapisu (text only). 
Naslov Prispevkom naj bosta dodana avtorjeva naslov in internetni naslov ali telefonska avtorja številka, na katerih bo dosegljiv uredniškemu odboru.

Kako poslati Na naslov uredništva ali članov uredniškega odbora je treba poslati tiskano in eleprispevek ktronsko različico prispevka.

Potrjevanje Uredniški odbor avtorju pisno potrdi prejetje prispevka. Avtorjem, ki sporočijo sprejetja tudi naslov svoje elektronske pošte, se potrditev pošlje po tej poti.

prispevka

Korekture Avtor opravi korekture svojega prispevka v treh dneh.

Naslov Ministrstvo za obrambo

uredniškega Generalštab Slovenske vojske

odbora Sodobni vojaški izzivi

Uredniški odbor

Vojkova cesta 55

1000 Ljubljana

Slovenija

Elektronski naslov

Odgovorna urednica:

liliana.brozic@mors.si

Prispevkov, ki ne bodo urejeni skladno s tem navodilom, uredniški odbor ne bo sprejemal. 


\section{INSTRUCTIONS FOR THE AUTHORS OF PAPERS FOR THE CONTEMPORARY MILITARY CHALLENGES AND THE MILITARY EDUCATION JOURNAL}

\section{Content-related instructions}

General The Contemporary Military Challenges is an interdisciplinary scientific expert magazine, which publishes papers on current topics, researches, scientific and expert discussions, technical or social sciences analysis from the field of security, defence and the military..

The Military Education Journal is a military professional and informative publication intended for education and informing on achievements and experiences in the field of military education, training and improvement.

What do we publish?

We publish papers in Slovene with abstracts translated into English. If so decided by the Editorial Board, we also publish papers in English with abstracts translated into Slovene.

We publish papers, which have not been previously published or sent to another magazine for publication. The author is held responsible for all possible copyright violations. If the paper has already been printed elsewhere, sent for publication or presented at an expert conference, the author must notify the editor, obtain the publisher's consent (if necessary) and indicate the reasons for republishing.

\section{Technical instructions}

Limitations regarding the length of the papers
The papers should consist of 16 typewritten double-spaced pages or 30,000 characters. At a minimum they should have 8 pages or 15,000 characters and at a maximum 24 pages or 45,000 characters. 
Reviews All papers are reviewed. The review is anonymous. With regard to the reviewer's assessment, the Editorial Board or the editor accepts the paper, demands modifications, if necessary, or rejects it. Upon receiving the reviewers' remarks, the author inserts them into the paper.

Due to an anonymous review process, the first page must be designed in the way that the author's identity cannot be recognized.

Next to the title, the author should indicate the category the paper belongs to according to him and according to the classification in the COBISS ${ }^{1}$. The classification is available on the magazine's internet page and at the responsible editor. The Editorial Board determines the final classification.

Proofreading The organizational unit responsible for publishing provides the proofreading of the papers. The proofread papers have to be approved.

Translating The translation of the papers or abstracts is provided by the organizational unit competent for translation or the School of Foreign Languages, Military Schools Centre.

Indicating The authors' name should be written in the upper left corner, aligned left.

the authors Example:

of the paper Name 1 Surname 1,

Name 2 Surname 2,

In the footnote, Slovenian authors should indicate the institution they come from. Foreign authors should also indicate the name of the state they come from.

Title of the The title of the paper is written below the listed authors. The font in the title is paper bold, size 16 points. The text of the title is centrally aligned.

Abstract The paper should have an abstract of a maximum 1,200 characters (20 lines). The abstract should include a short presentation of the topic, particularly the results and the findings. General findings and reflections do not belong in the abstract, but rather in the introduction.

Abstract in The authors must also submit the translation of the abstract into English. The translaEnglish tion of the abstract is likewise limited to a maximum of 1,200 characters (20 lines).

Key words Key words (3-5 also in the English language) should be bold with a justified text alignment.

Text

The authors should submit their papers on an A4 paper format, with 1.5 line spacing, fontArial size 12 points. At the upper and the bottom edge, there should be approx. $3 \mathrm{~cm}$ of space; the left margin should be $2 \mathrm{~cm}$ wide and the right margin $4 \mathrm{~cm}$. Each page consists of approx. 30 lines with 62 characters. The text should have a justified alignment, without indents at the beginning of the paragraphs. 
A brief pre- The authors should prepare a brief presentation of their expert or scientific work. sentation of The presentation should not exceed 600 characters (10 lines, 80 words). If there the authors are several authors, each should be presented individually, as shortly and as comprehensively as possible. These texts should be placed at the end of the paper, after the cited literature.

Text structuring

Individual chapters should be separated with independent subtitles and adequately numbered.

Example:

1 Introduction

2 Title of the chapter $\left(1^{\text {st }}\right.$ level $)$

2.1 Subtitle ( $\left.2^{\text {nd }} l e v e l\right)$

2.1.1 Subtitle $\left(3^{\text {rd }}\right.$ level $)$

2.1.1.1 Subtitle $\left(4^{\text {th }}\right.$ level $)$

Referencing In the bibliography, only the authors of references one refers to in the paper should be listed, in the alphabetical order. The entire reference has to be in compliance with the Harvard citing style.

Example:

Surname, name (can also be the initial of the name), year. Title of the work. Place. Publishing House.

\section{Example:}

Urlich, W., 1983. Critical Heuristics of Social Planning. Chicago: University of Chicago Press.

With certain papers published in journals, the author should indicate, at the end of each reference, a page on which the paper can be found.

\section{Example:}

Urlich, W., 1983. Critical Heuristics of Social Planning. Chicago: University of Chicago Press. pp. 45-100.

Referencing All references start the same as the references for the printed sources, only that internet sources the usual part is followed by the information about the Internet page on which the document was found as well as the date on which it was found. The information about the time that the document was found on the Internet is important, because the WWW environment changes constantly.

Urlich, W., 1983. Critical Heuristics of Social Planning. Chicago: University of Chicago Press. p. 45-100. http://www.mors.si/index.php?id=213, 17 October 2008.

When referencing interesting WWW pages in the text (not citing an individual document) it is enough to state only the Internet address (http://www.vpvs.uni-lj. si). A separate reference at the end of the text is therefore not necessary. 
Citing

Figures, diagrams, tables
When citing sources in the text, indicate only the surname of the author and the year of publication. Example: ..... (Smith, 1997) ...

When making a direct reference to a text, the cited part should be adequately marked with quotation marks and followed by the exact page of the text which the citing is taken from.

Example: ...(Smith, 1997, p.15) ...

Figures, diagrams and tables in the paper should be prepared in separate files which allow for proofreading corrections. The place in the text where the picture should be inserted must be clearly indicated. The total length of the paper must not surpass the given limitation.

Should the author not be able to submit the graphical supplements in the electronic form due to technical reasons, it is exceptionally acceptable to enclose the figures to the text. In this case the author must write a sequence number and a title on the back of each picture and leave enough space in the text to include it. The text must likewise contain the title and the sequence number of the figure. Diagrams are considered figures.

All figures and tables are numbered. The numbering is not uniform and not linked with the numbering of the chapters. The title of the figure is stated beneath it and the title of the table is stated above it.

As a rule, the paper should include at least one reference to a figure or a table.. Reference to a figure or a table is: ... (Figure 5) (Table 2)

Example of a figure: $\quad$ Example of a table:

Table 2: Title of the table

Figure 5: Title of the figure

Footnotes

The numbering of the footnotes is not related to the structure of the text and starts with number 1 in each paper. We want to stress that the aim of the footnotes is to explain the thoughts written in the text and not to reference literature.

Abbreviati- When used for the first time, the abbreviations in the text must be explained in ons parenthesis; therefore no additional list of abbreviations is needed. If the abbreviations or terms are written in English, the appropriate Slovenian term should be written along with the English original and possibly the English abbreviation in the parenthesis.

Format type The Editorial Board accepts only the texts written with a MS Word text editor and of the paper only exceptionally those in the 'text only' format. 
Author's Each paper should include the author's address, e-mail or a telephone number, so address that the Editorial Board can reach him or her.

Sending A print or an electronic version of the paper should be sent to the address of the the paper Editorial Board or the members of the Editorial Board.

Confirma- The Editorial Board sends the author a written confirmation regarding the tion of the reception of the paper. The authors who also list their e-mails receive the confirreception of mation via e-mail.

the paper

Corrections The author makes corrections to the paper within three days.

$\begin{array}{ll}\text { Editorial } & \text { Ministry of Defence } \\ \text { Board } & \text { Slovenian Armed Forces } \\ \text { address } & \text { General Staff } \\ & \text { Contemporary Military Challenges } \\ & \text { Editorial Board } \\ & \text { Vojkova cesta 55 } \\ & \text { 1000 Ljubljana } \\ & \text { Slovenia } \\ & \text { Electronic address: } \\ & \text { Editor in Chief: } \\ & \text { liliana.brozic@mors.si }\end{array}$

The Editorial Board will not accept papers, which will not be in compliance with the above instructions. 



Sodobni vojaški izzivi - 18/št. 1

Vsebina

Pavel Vuk

TEORETIČNI VIDIKI ODNOSA MED STRATEGIJO IN OBRAMBNIM PLANIRANJEM NA VARNOSTNO-OBRAMBNEM IN VOJAŠKEM PODROČJU

THEORETICAL ASPECTS OF THE RELATION BETWEEN THE STRATEGY AND DEFENCE PLANNING IN SECURITY, DEFENCE AND MILITARY FIELDS

Mehmedin Tahirović Olivera Injac

Gregor Zupan

Vinko Vegič

Viktor Potočnik

Maja Garb

Andreas

Hauptmann Kaiser
RAZVOJ OBRAMBNEGA SISTEMA ČRNE GORE DEVELOPMENT OF THE DEFENCE SYSTEM OF MONTENEGRO

GOSTUJOČI OBRAMBNI ATAŠEJI: PREDNOSTI IN POMANJKLIVOSTI ROVING DEFENCE ATTACHÉS: ADVANTAGES AND DISADVANTAGES

POJAV IN KONCEPTUALIZACIJA HIBRIDNEGA VOJSKOVANJA EMERGENCE AND CONCEPTUALISATION OF HYBRID WARFARE

KONCEPT EŠALONIRANJA OGNJEV IN SISTEMI OGNJENE PODPORE $\checkmark$ SLOVENSKI VOJSKI

ECHELONMENT OF FIRES AND INDIRECT FIRE SYSTEMS IN THE SLOVENIAN ARMED FORCES

RAZVOJ POJMA IN KONCEPTA CIVILNO-VOJAŠKEGA SODELOVANJA IN USKLAJEVANJA V MIROVNIH OPERACIJAH DEVELOPMENT OF THE TERM AND THE CONCEPT OF CIVIL-MILITARY CO-OPERATION AND CO-ORDINATION IN PEACE OPERATIONS

GORSKE ENOTE NEMŠKIH OBOROŽENIH SIL

THE GERMAN ARMED FORCES MOUNTAIN TROOPS 